
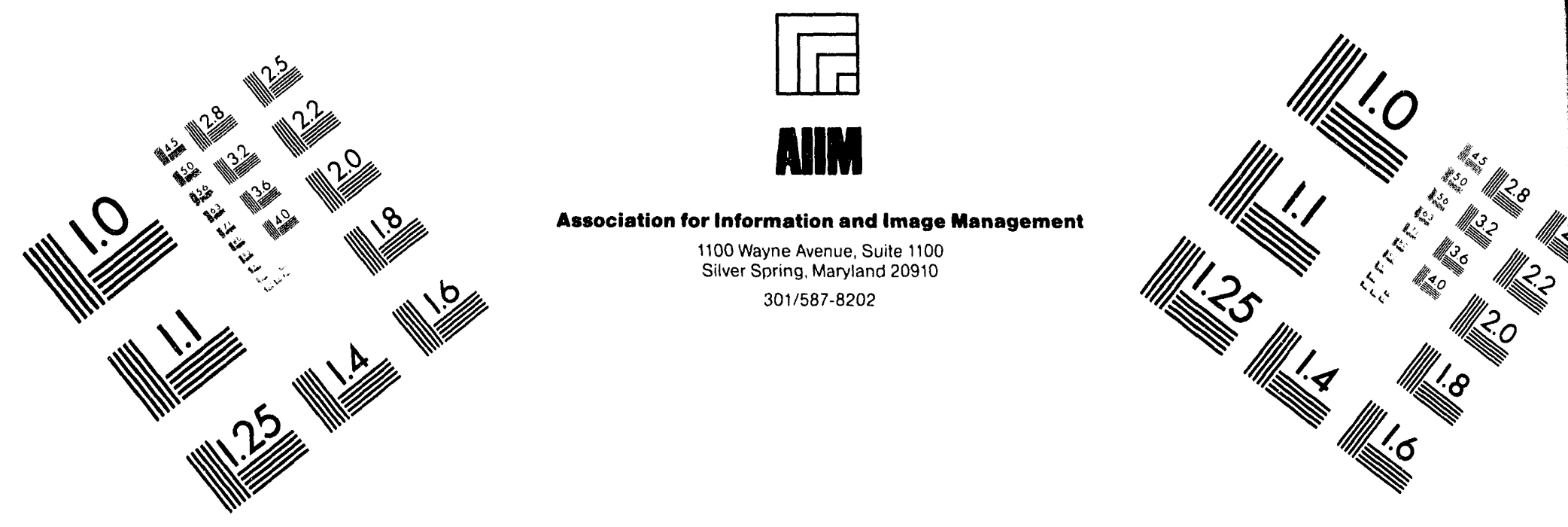

\title{
Centimeter
}

$\begin{array}{llllllllllllllll}1 & 2 & 3 & 4 & 5 & 6 & 7 & 8 & 9 & 10 & 11 & 12 & 13 & 14 & 15 & \mathrm{~mm}\end{array}$

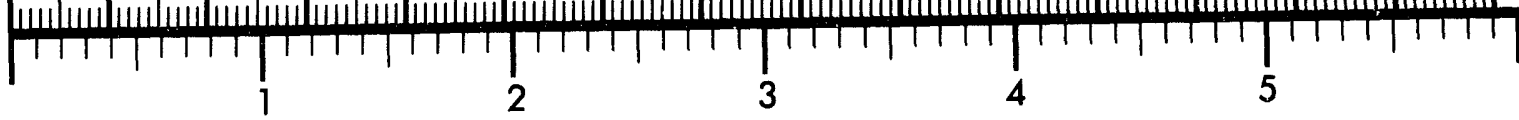
Inches
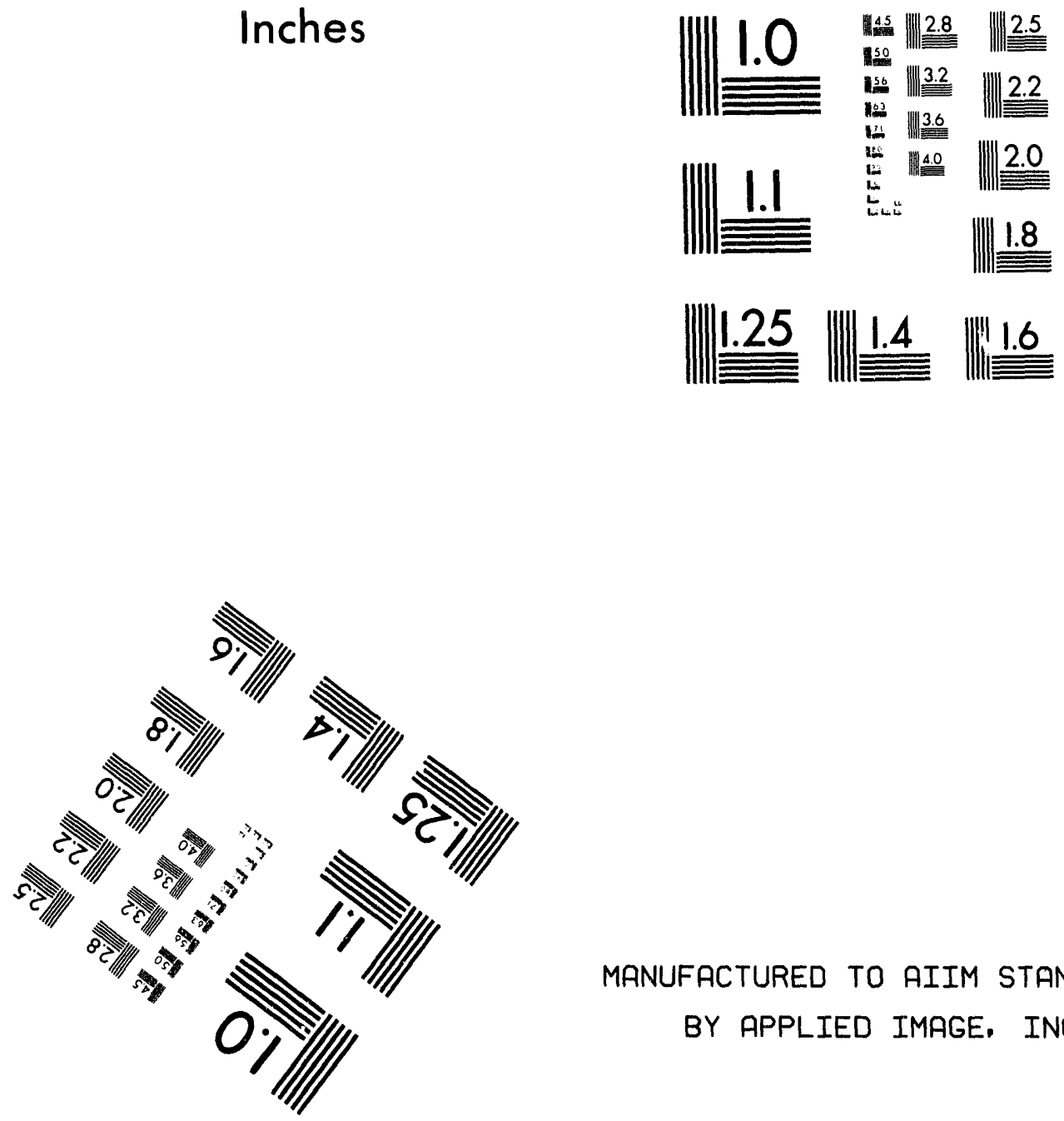

MANUFACTURED TO AIIM STANDARDS BY APPLIED IMAGE, INC.

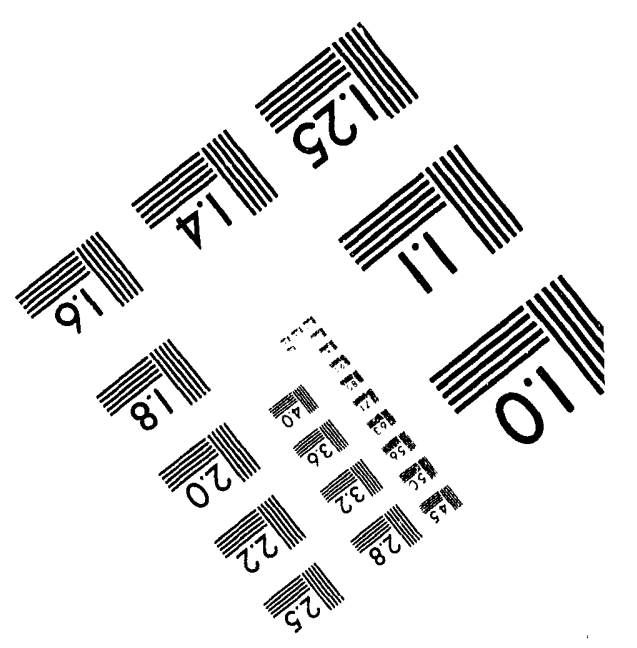



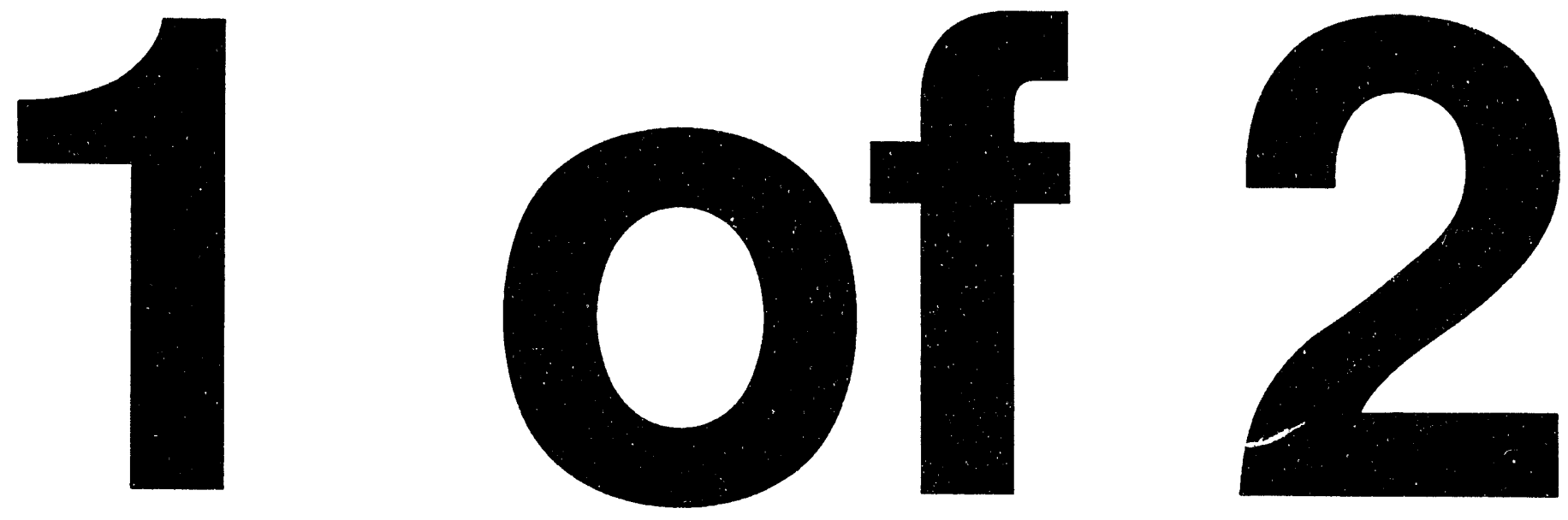
DOE/RL-93-73

Revision 0

UC-630,721

\section{Area Process Trenches Closure Plan}

Date Published

August 1994

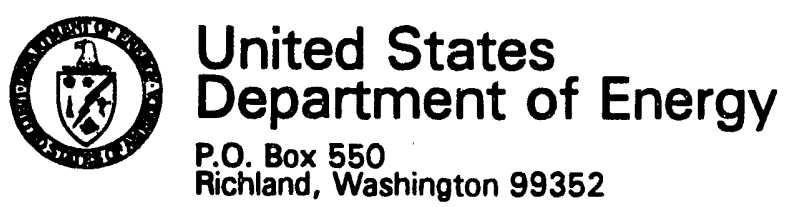

Richland, Washington 99352

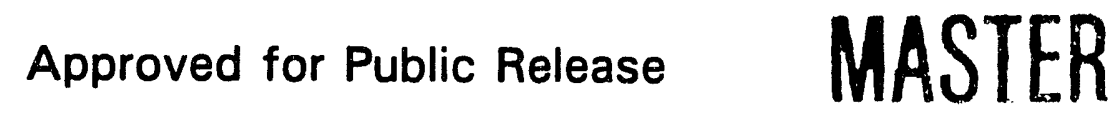




\section{AREA PROCESS TRENCHES CLOSURE PLAN}

The Hanford Facility is owned by the U.S. Government and operated by the U.S. Department of Energy, Richland Operations Office. Dangerous waste and mixed waste (containing both radioactive and dangerous components) are produced and managed on the Hanford Facility. The dangerous waste is regulated in accordance with the Resource Conservation and Recovery Act of 1976 and the State of Washington Hazardous Waste Management Act of 1976 [as administered through the Washington State Department of Ecology Dangerous Waste Regulations, Washington Administrative Code 173-303]. The radioactive component of mixed waste is interpreted by the U.S. Department of Energy to be regulated under the Atomic Energy Act of 1954; the nonradioactive dangerous component of mixed waste is interpreted to be regulated under the Resource Conservation and Recovery Act of 1976 and Washington Administrative Code 173-303.

For the purposes of the Resource Conservation and Recovery Act, the Hanford Facility is considered to be a single facility. The single dangerous waste permit identification number issued to the Hanford Facility by the U.S. Environmental Protection Agency and the Washington State Department of Ecology is Environmental Protection Agency/State Ident ification Number WA890008967. This identification number encompasses a number of treatment, storage, and/or disposal units within the Hanford Facility. Treatment, storage, and/or disposal units that are no longer operating will be closed under interim status (using final status standards in Washington Administrative Code 173-303-610).

Since 1987, Westinghouse Hanford Company has been a major contractor to the U.S. Department of Energy, Richland Operations Office and has served as co-operator of the 300 Area Process Trenches, the waste management unit addressed in this closure plan. For the purposes of the Resource Conservation and Recovery Act, Westinghouse Hanford Company is identified as 'co-operator.' Any identification of Westinghouse Hanford as an operator elsewhere in this closure plan is not meant to conflict with Westinghouse Hanford Company's designation as co-operator, but is rather based on Westinghouse Hanford Company's contractual status (i.e., as a management and operations contractor) for the U.S. Department of Energy.

The 300 Area Process Trenches Closure Plan (Revision 0) consists of a Resource Conservation and Recovery Act Part A Dangerous Waste Permit Application, Form 3 and a Resource Conservation and Recovery Act Closure Plan. An explanation of the Part A Permit Application, Form 3 submitted with this document is provided at the beginning of the Part A Section. The closure plan consists of nine chapters and six appendices.

This treatment, storage, and/or disposal unit closure is unique because it is integrated with the Comprehensive Environmental Response, Compensation, and Liability Act of 1980 300-FF-1 Operable Unit remedial action. This integration is necessary to ensure that the activities of the two units remain physically consistent in accordance with the Hanford Federal Facility Agreement and Consent Order Action Plan (Section 5.5) so that unit contamination is most economically and efficiently addressed. 
DOE/RL-93-73, Rev. 0

$08 / 15 / 94$

This page intentionally left blank. 


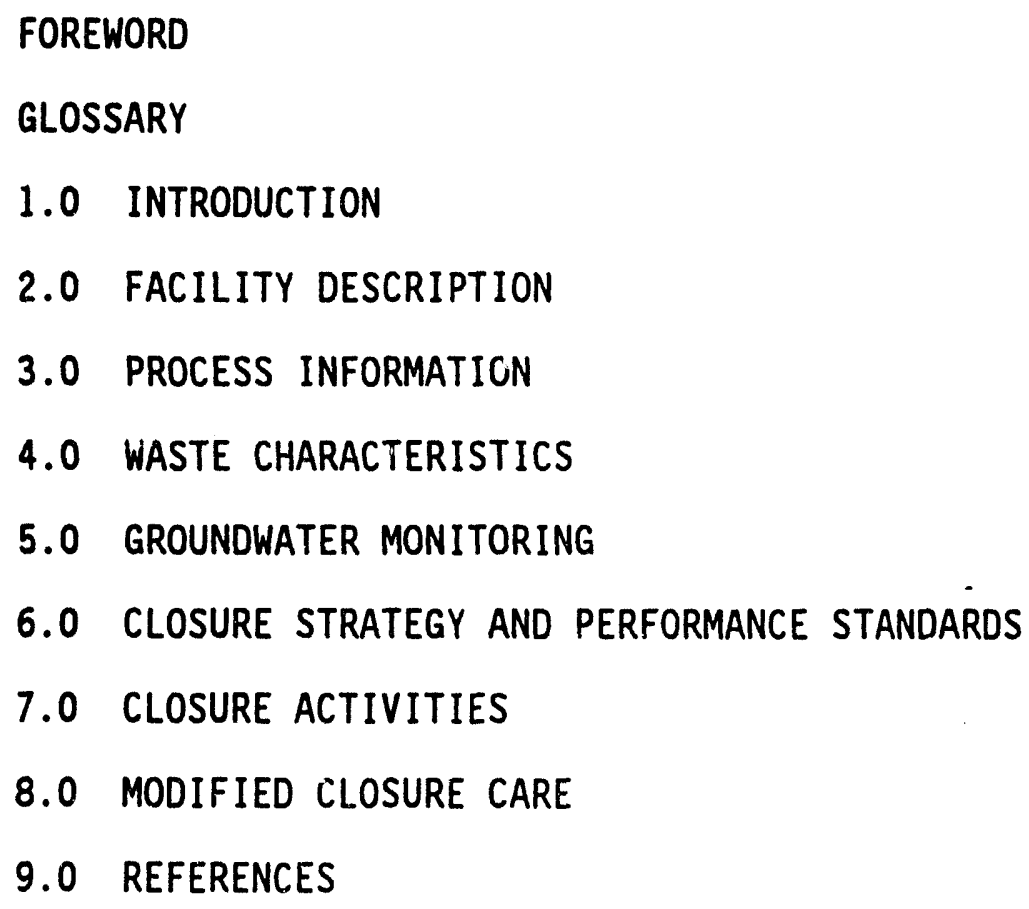


DOE/RL-93-73, Rev. 0

$08 / 15 / 94$

1
2
3
4
5

This page intentionally left blank. 


\section{GLOSSARY}

300 APT

ALARA

CERCLA

CFR

DOE

DOE-RL

DQO

Ecology

EPA

ERA

ERDF

FS

HEDL

HBL

HSBRAM

IRIS

LOQ

MCL

MPC

MTCA

O\&M

OU

PCB

PNL

PS

QA

QAPjP

QC

RA

RAO

RAWP

RCRA

RD

RDR

RI
300 Area Process Trenches

as low as reasonably achievable

Comprehensive Environmental Response, Compensation, and Liability Act of 1980 Code of Federal Regulations

U.S. Department of Energy U.S. Department of Energy, Richland Operations Office data quality objective

Washington State Department of Ecology U. S. Environmental Protection Agency expedited response action Environmental Restoration Disposal Facility

feasibility study

Hanford Engineering Development Laboratory

health-based level

Hanford Site Baseline Risk Assessment Methodology

Integrated Risk Information System

limit of quantitiation

maximum contaminant levels

maximum permissible concentration

Model Toxics Control Act

Operation \& Maintenance

operable unit

polychlorinated biphenyl

Pacific Northwest Laboratories

300 Area Process Sewer System

qual ity assurance

quality assurance project $p l a n$

quality control

remedial action

remedial action objectives

Remedial Action Work Plan

Resource Conservation and Recovery Act of 1976

remedial design

Remedial Design Report

remedial investigation 


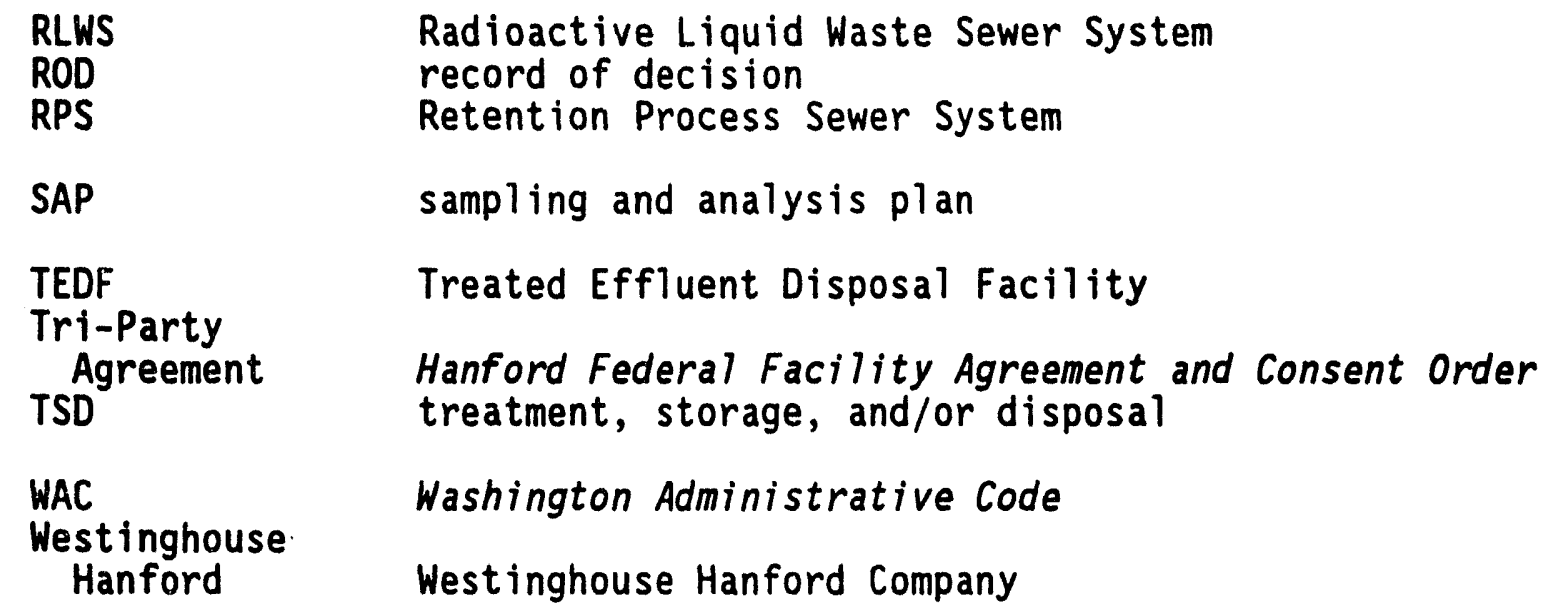


DOE/RL-93-73, Rev. 0

$08 / 15 / 94$

Part A Permit Application, Form 3

7

8

$A-i$ 


\section{DOE/RL-93-73, Rev. 0

This page intentionally left blank. 
Piease print or type in the unsheded arese only

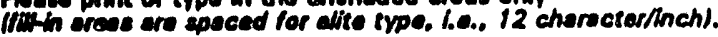

\section{DANGEROUS WASTE PERMIT APPLICATION}

1. EPA/STATE 1.D. NUMBEA
\begin{tabular}{|l|l|l|l|l|l|l|l|l|l|l|l|}
\hline W & $A$ & 7 & 8 & 9 & 0 & 0 & 0 & 8 & 9 & 6 & 7 \\
\hline
\end{tabular}

FOR OFFICLAL USE ONLY

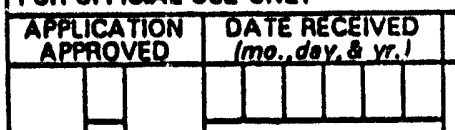

COMMENTS

\section{U1. FIRST OA REVISED APPLICATION}

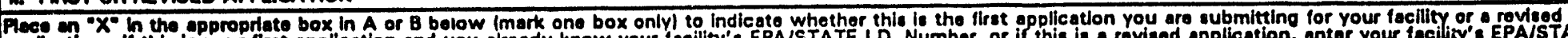

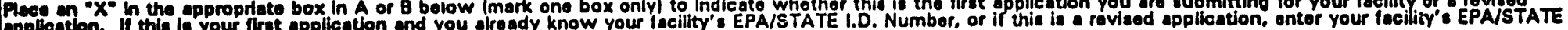
i.b. Number in Section 1 abow.

A. FIRST APPUCATION (plece en " $X$ " below end provide the eppropriate datel

\section{$\square$ 1. EXISTIWO FACILTY isee instructions for definitlon of "existing " focillty.
Complete item below.) \\ MQ. DAY YR. FOR EXISTING FACILITIES PROVIOE THE DATE (MO

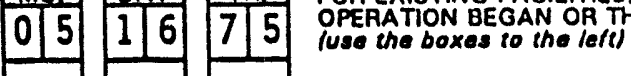

8. REVISED APPLICATION (plece on " $X$ " below ard complete Section l abovel

Q] 1. FACILITY HAS AN INTEAIM STATUS PERMIT
2. NEW FACILITY (Complets item below)

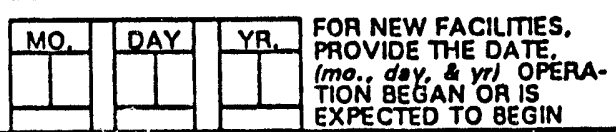

iil. PAOCESSES - CODES AND CAPACITIES

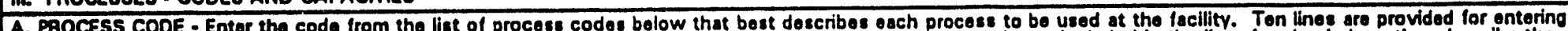

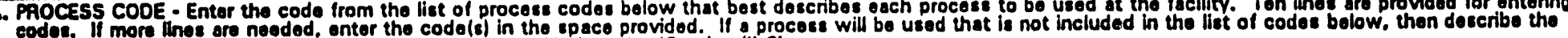

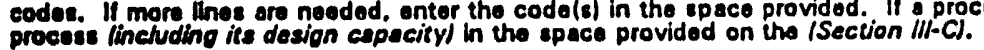

B. PROCESS DESIGN CAPACTY - For eech code entered in column A enter the capacity of the process.

1. AMOUNT - Entar the emount.

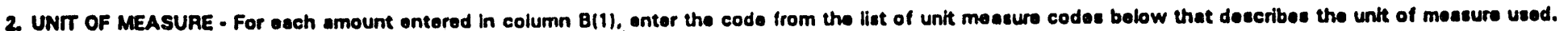

Onhy the units of moseure thet are listed bolow should be used.

\section{\begin{tabular}{lll} 
& PRO. & APPAOPRIATE UNITS OF \\
$\therefore$ PROCESS & CESS MEASURE FOR PAOCESS \\
\hline
\end{tabular}}

Storega:

CONTANER (barrol, drum, otc)

WASTE PILE

SUPFACE IMPOUNDMENT

Dieposal:

NUECTION WELL
LANDFILL
LAND APPUICATION
OCEAN DISPOSAL

SUPFACE IMPOUNDMENT

\begin{abstract}
SO1 GALLONS OR LTTERS
SO2 GALLONS OR LITERS

SO3 CUBIC YAROS OR

SO4 GALLONS OR LITERS
\end{abstract}

\section{D8O GALLONS OR LITERS \\ D81 ACRE-FEET ithe volume that would cover ona ocre to. depth of one fooll OR HECTARE-METER \\ O82 ACRES OR HECTARES
D83 GALLONS PER DAY OR \\ DQ4 LITERS PER DAY}

UNTT OF MEASURE

UNT OF MEASURE

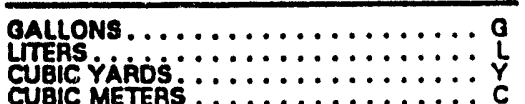

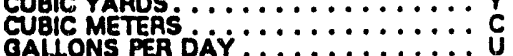

$\begin{array}{lll}\text { PRO- } & \text { APPAOPRIATE UNTS OF } \\ \text { PAOCESS } & \text { CESS } & \text { MEASURE FOA PROCESS } \\ \text { CODESIGN CAPACITY }\end{array}$

Trostmont:

TANK

SURFACE IMPOUNDMENT

INCINERATOR

T01

TO2

T03

OTHER (Uso for physical, chemical, TO4 thormal or biological trestmont

processos not occurring in tanka.

surface impoundments or inciner-

the space provided; Section III-C.)

\begin{tabular}{|c|c|}
\hline UNIT OF MEASURE & $\begin{array}{l}\text { UNIT OF } \\
\text { MEASURE } \\
\text { CODE }\end{array}$ \\
\hline $\begin{array}{l}\text { LTERS PER OAY } \\
\text { TONS PER HOUR } \\
\text { METRIC TONS PER } \\
\text { GALLONS PER HOU } \\
\text { LITERS PER HOUR. }\end{array}$ & $\ldots \ldots$ V \\
\hline
\end{tabular}

GALLONS PER DAY OR LITERS PER DAY GALLONS PER PEAY DAY TONS PEA HOUA OR METAIC TONS PER HOUA: METAIC TONS PER HOUA: GALLONS PEAOH

GALLONS PER DAY OR UTERS PER DAY

EXAMPLE FOR COMPLETING SECTION III (shown in line numbers $X-1$ end $X-2$ below): A tucifity has two storage tenks, one tenk can hold 200 gallons ond the other can hold 400 gollons. The tacility also has an incinerator that can bum up to 20 gallone par hour.

\begin{tabular}{|c|c|c|c|c|c|c|c|c|c|c|c|}
\hline \multirow[b]{2}{*}{$\left|\begin{array}{cc}L & N \\
1 & U \\
N & M \\
N & B \\
E & E \\
\text { A }\end{array}\right|$} & \multirow{2}{*}{\multicolumn{3}{|c|}{$\begin{array}{c}\text { A. PRO- } \\
\text { CESS } \\
\text { CODE } \\
\text { (from list } \\
\text { abovel }\end{array}$}} & \multicolumn{2}{|l|}{ 8. PROCESS DESIGN CAPACITY } & \multirow[b]{2}{*}{$\begin{array}{c}\text { FOR } \\
\text { OFFICIAL } \\
\text { USE } \\
\text { ONLY }\end{array}$} & \multirow[b]{2}{*}{$\mid \begin{array}{cc} & N \\
L & U \\
N & M \\
N & B \\
E & E \\
R\end{array}$} & \multirow[b]{2}{*}{$\begin{array}{c}\text { A. PRO- } \\
\text { CESS } \\
\text { CODE } \\
\text { (from list } \\
\text { obove) }\end{array}$} & \multicolumn{2}{|l|}{ B. PAUCESS DESIGN CAPACITY } & \multirow[b]{2}{*}{$\begin{array}{c}\text { FOR } \\
\text { OFFICIAL } \\
\text { USEE } \\
\text { ONLY }\end{array}$} \\
\hline & & & & 1. AMOUNT & $\begin{array}{c}\text { 2. UNIT } \\
\text { OF MEA- } \\
\text { SURE } \\
\text { lenter } \\
\text { codel }\end{array}$ & & & & 1. & $\begin{array}{c}\text { 2. UNIT } \\
\text { OF MEA- } \\
\text { SURE } \\
\text { (enter } \\
\text { code) }\end{array}$ & \\
\hline$x-1$ & $s$ & 0 & 2 & 600 & $G$ & & 5 & & & & \\
\hline ? & $\tau$ & 0 & 3 & 20 & $\varepsilon$ & & 6 & & & & \\
\hline & D & 8 & 4 & $3,000,000$ & U & & 7 & & & & \\
\hline 2 & & & & & & & 8 & & & & \\
\hline 3 & & & & . & & & 9 & & & & \\
\hline 4 & & & & & & & 10 & & & & \\
\hline
\end{tabular}


Continued from the iront.

processes (cominued)

SPACE FOA ADOTIONAL PROCESS CODES OR FOR DESCAIBINO OTHER PAOCESS (COd๑ TO4\%). FOR EACH PROCESS ENTERED HERE INCLUDE DESIGN CAPACITY. D84

The 300 Area Process Trenches received nonregulated process cooling water from operations in the 300 Area of the Hanford Site. The process trenches also received dangerous waste from several research and development laboratories and from the fuels fabrication process. The waste was discharged to the 300 Area Process Trenches and allowed to percolate into the soil column underlying the trenches. The annual quantity of waste identified under item IV.B reflects the total flow to the process trenches in one year, and not a volume of dangerous waste discharged to the unit. This estimate was made because accurate records are unavailable regarding dangerous waste volumes discharged to the trenches. The process trenches were designed to percolate up to $3,000,000$ gallons $(11,365,200$ 1iters) per day of waste water. The 300 Area Process Trenches no Tonger receive dangerous waste and will be closed under interim status. The process design capacity reflects the maximum volume of water that was discharged daily, rather than the physical capacity of the unit.

\section{N. DESCAIPTION OF OANGEROUS WASTES}

A. DANOEAOUS WASTE NUMBEA - Enter the four digit number from Chaptor 173-303 WAC for ecch listed dengerous warte you will handle. It you handle denporous wastee which ans not lieted in Chaptor $173-303$ WAC, onter the four digit number(a) that describese the charecteristics and/or the toxic con eminente of those dengerous wastas.

8. ESTIMATED ANNUAL QUANTTY . For ecch llated warte ontered in column A ontimato the quantity of that wante that will be hondled on an annual beale. For each characterietic or toxic contaminent onterod in column A ostimate the total annual quantity of all the non-listed wastels) that will be handled which poseass that characterietic or contaminant.

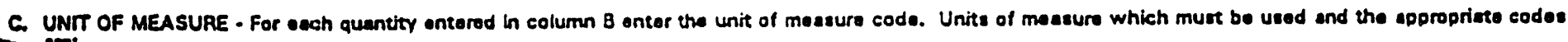
an:

$\frac{\text { ENGLISH UNTT OF MEASURE }}{\text { POUNDS } \ldots \ldots \ldots \ldots \ldots \ldots \ldots \ldots \ldots \ldots}$

$\frac{\text { METRIC UNTT OF MEASURE }}{\text { KILOGRAMS } \ldots \ldots \ldots \ldots \ldots \ldots \ldots \ldots \ldots}$

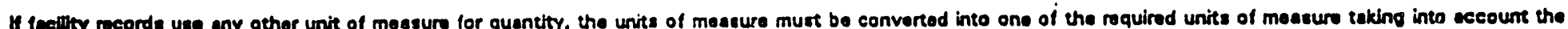
epproprate density of specifle gravity of the waste.

D. PROCESSES

\section{PROCESS CODES:}

For listed dangerous waste: For eech listed dangerous waste enterod in column A select the codels) trom the list of procese codes contained in Secton lil to indieate how the wate will be stored, treated, and/or dieposed of at the lecility.

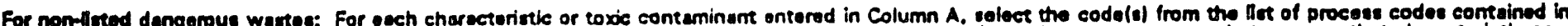

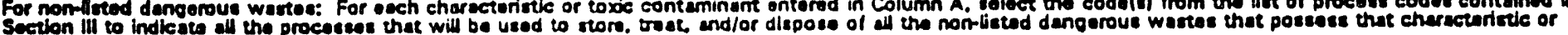
Section ift to indieate

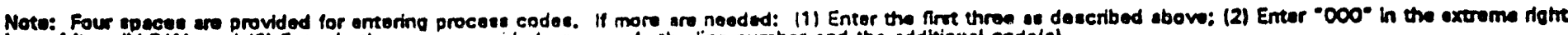

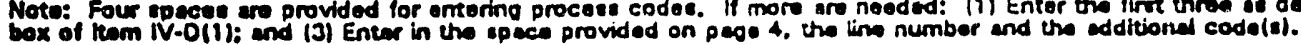

2. Process DescripnoN: H a code in not listed for a procese thrt will be ueed. doecribe the procese in the spece provided on the form.

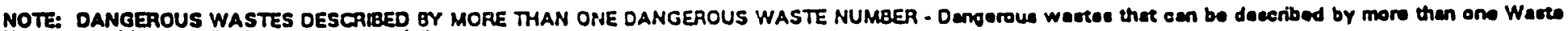
Number thall be described on the form as foliows:

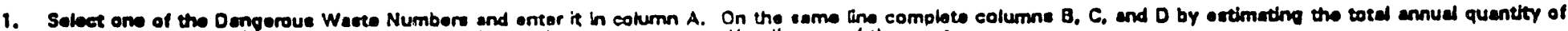
the warte and deseribing all the processes to be used to troct, store, and/or dispose of the wasto.

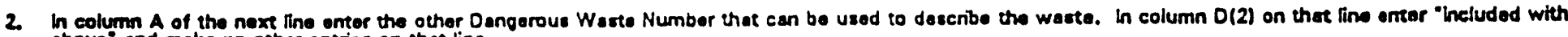
above" and make no other entries on that line.

1. Repeat step 2 for esch other Dangorous Warte Number that cen be used to describe the dengeroue waete.

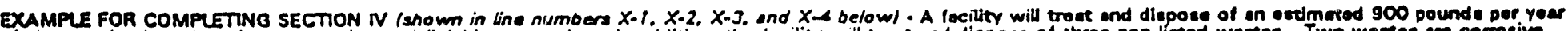

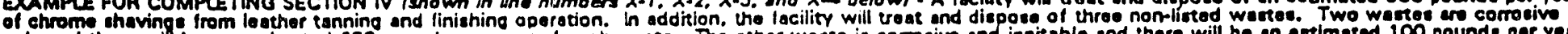

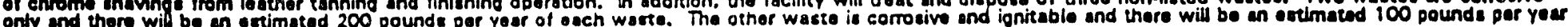
of thet weste. Treatment will be in an incinerator and dleposal will be in a landfill.

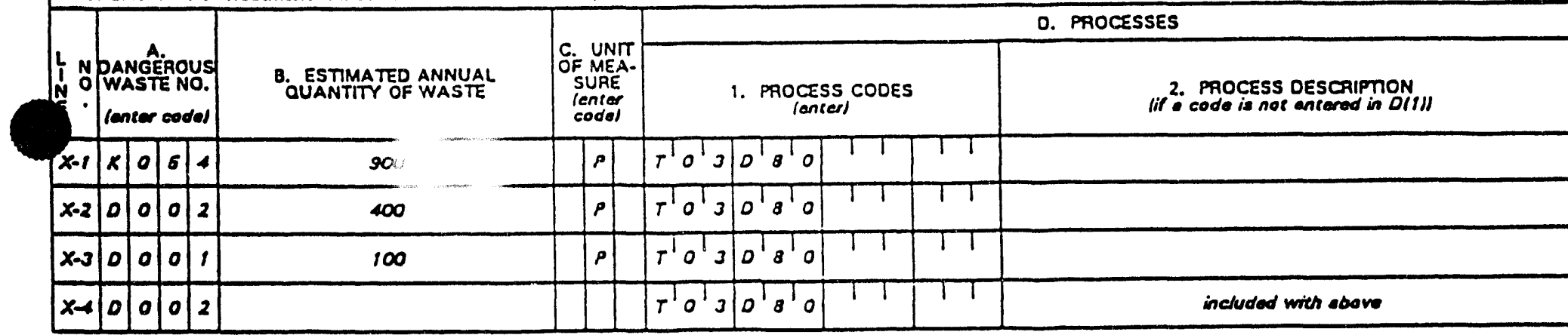


300 Area Process Trenches

Rev. 3, 08/12/94, Page 3 of 7

Continued trom peoe 2.

MOTE: Photocopy thls page defore completing if you hove more than 26 westes to list.

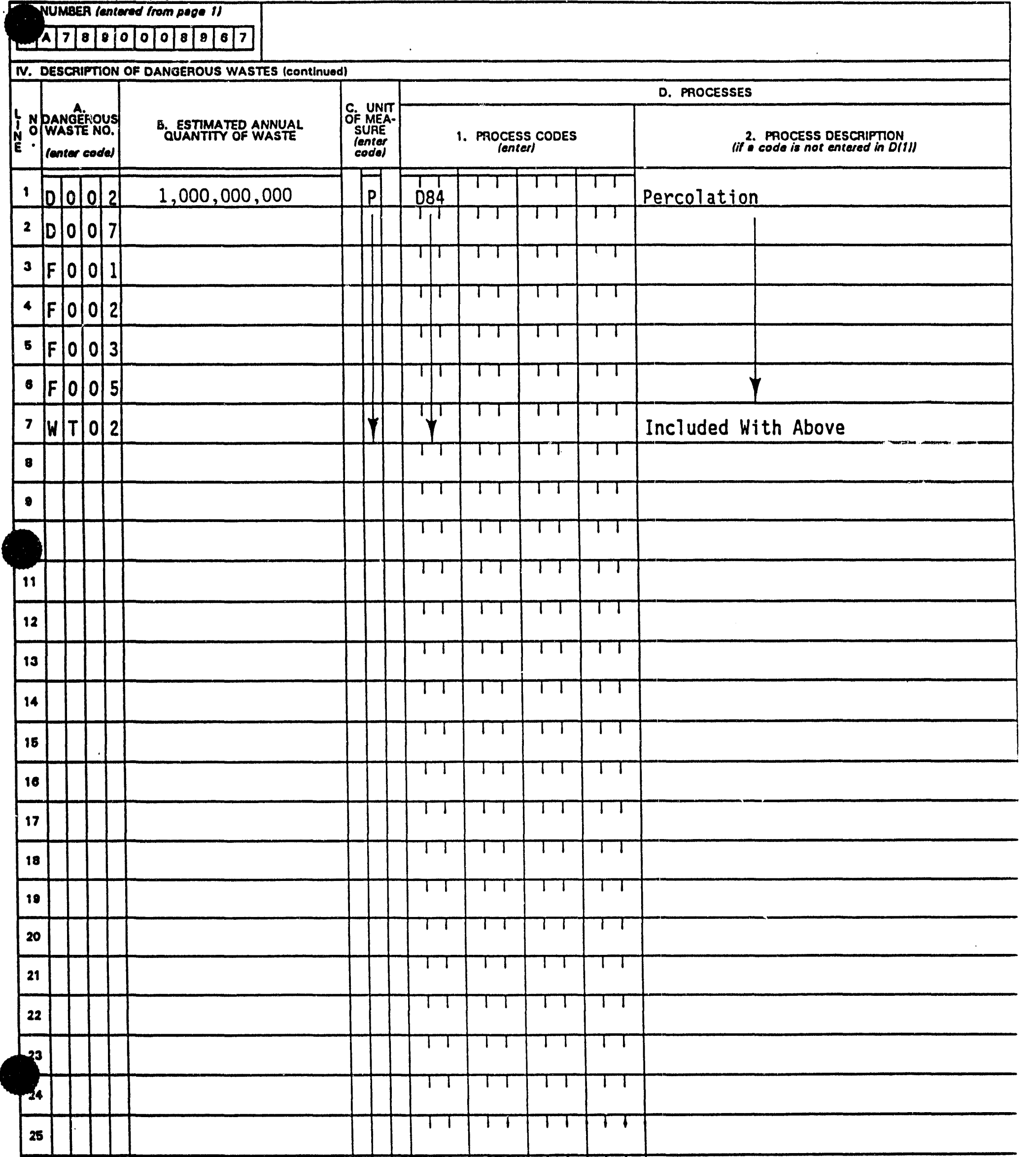

28 
Conthued from the front.

DESCRIPTION OF DANGEROUS WASTES (continued)

SE THIS SFACE TO LIST ADDITIONAL PROCESS CODES FROM SECTION DII) ON PAGE 3.

The 300 Area Process Trenches received dangerous waste discharges from research and development laboratories in the 300 Area and from fuels fabrication processes. This waste consisted of state-only toxic (WT02), corrosive (D002), chromium (D007), spent halogenated solvents (F001, F002, and F003), and spent nonhalogented solvent (F005). Accurate records are unavailable concerning the amount of dangerous waste discharged to the trenches. The estimated annual quantity of waste (item IV.B) reflects the total quantity of both regulated and nonregulated waste water that was discharged to the unit.

V. FACILTTY DRAWINO

All exleting faclitloe muet include in the apece provided on page 5 a ecale drawing of the facility lsee instructions for more detaill.

Vi. PHOTOGRAPHS

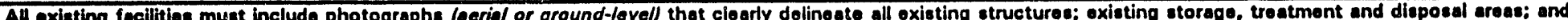
sites of future storage. treatmont or disposal areas (see instructions for more detsill.

VII. FACILTY GEOGAAPHIC LOCATION This information is provided on the attached drawings and photos.

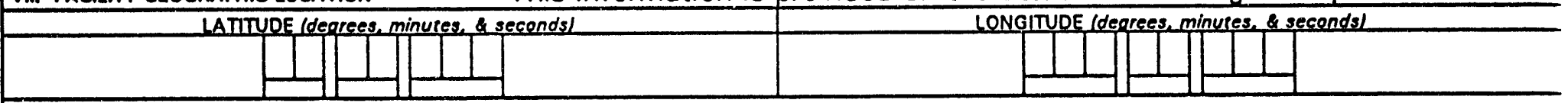

\section{FACILITY OWNER}

A. Af the facility owner is aleo the facility operator as listed in Section VII on Form 1. "Goneral Information", place an "X" in the box to the left and aklp to Section IX bolow.

B. If the fecillty owner le not the fecillty operator as liatod in Section VII on Form 1, complete the following Hems:

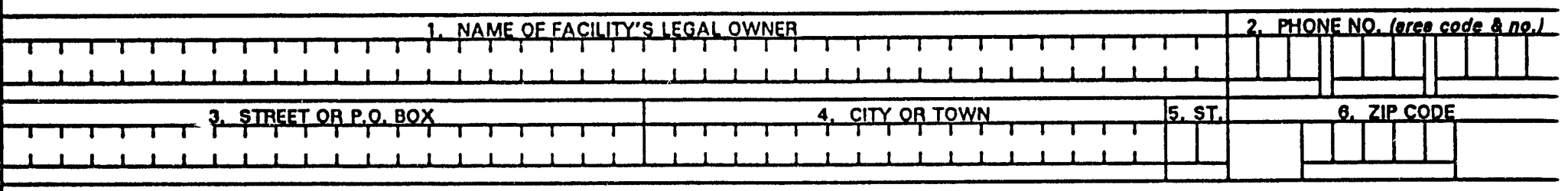

IX. OWNER CERTIFICATION

1 certify under penalty of low that l have personally examined and am familiar with the information submitted in this and all attoched documents, and that besed on my inquiry of those individuals mmediately responsible for obtaining the intormation.

NAME (prinf or type)

John D. Wagoner, Manager

U.S. Department of Energy

hland Operations Office

OPERATOR CERTIFICATION
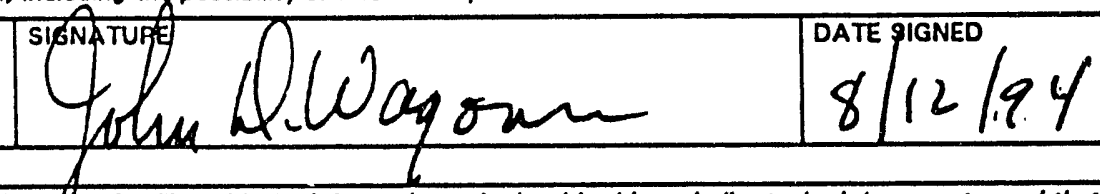

Vcentify under penafty of low that l have personally examined and $m$ familise with the information submitted in this and all artuched documents. and that based on my inquity of those individuals immediately responsible for obteining fime informotion, l believe that the submitted intormation is true, eccurate, and complete. I am ewere that there are significant penalties for submitting false information. indluding the possibility of fine and imprisonment.

\begin{tabular}{|c|l|l|}
\hline $\begin{array}{c}\text { NAME (Print or typel } \\
\text { SEE ATTACHMENT }\end{array}$ & SIGNATURE & DATE SIGNED \\
\hline
\end{tabular}




\section{OPERATOR CERTIFICATION}

I certify under penalty of law that I have personally examined and am familiar with the information submitted in this and all attached documents, and that based on my inquiry of those individuals immediately responsible for obtaining the information, I believe that the submitted information is true, accurate, and complete. I am aware that there are significant penalties for submitting false information, including the possibility of fine and imprisonment.
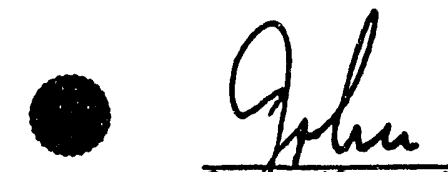

Ql.

W

owrer/Operator

one

John D. Wagoner, Manager

W.S. Department of Energy

Richland Operations Office

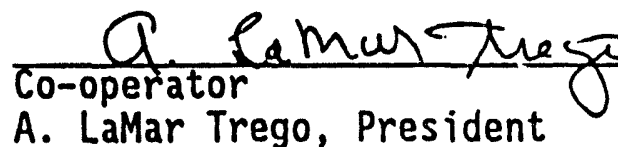

$\frac{8-8-94}{\text { Date }}$

A. LaMar Trego, President

$8 / 12 / 94$

Hestinghouse Hanford Company 


\section{Area Process Trenches}

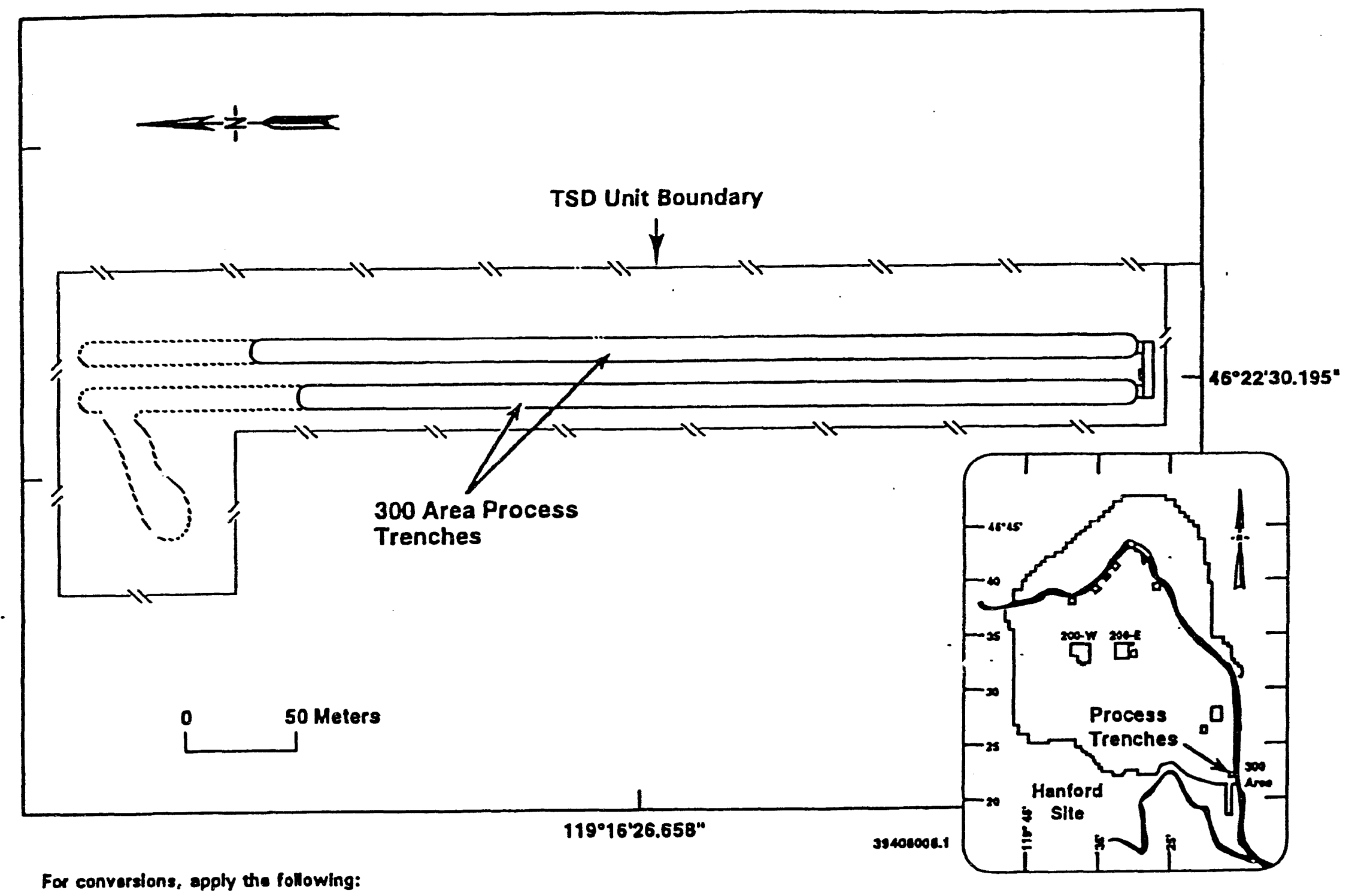

Meters to feet - divide metors by 0.3048 . 


\section{AREA PROCESS TRENCHES}

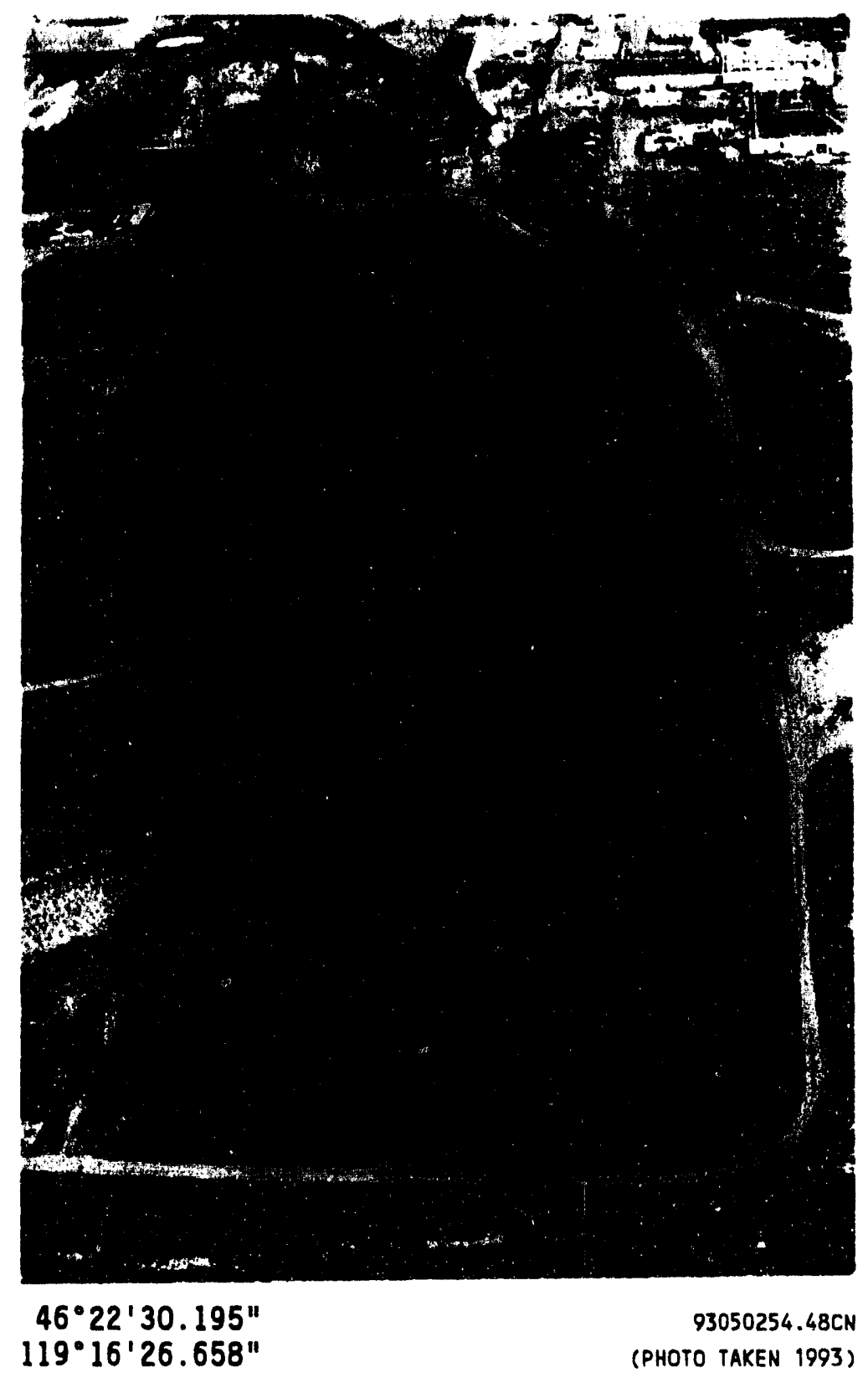




\section{CONTENTS}

1.0 INTRODUCTION . . . . . . . . . . . . . . . . . . . . . 1-1

1.1 BACKGROUND . . . . . . . . . . . . . . . . . . 1-1

1.2 INTEGRATION OF RCRA AND CERCLA PROCESSES FOR CLOSURE OF THE 300 APT . . . . . . . . . . . . . . . . . . . . . . 1-2

1.2.1 CERCLA RA Process and TSD Unit Closure . . . . . . . . 1-2

1.2.2 Closure Plan Format and Document Incegration . . . . . . 1-4

1.2.3 Basis for RCRA/CERCLA Integration .......... 1-4

1.2.4 RCRA and CERCLA Regulator Interface . . . . . . . . . 1-6

1.2.5 RCRA Permitting Issues and Regulator Agreements . . . . 1-7

1.2.6 RCRA Unit Responsibilities .. . . . . . . . . . . 1-8

1.3300 APT CLOSURE PLAN CONTENTS . . . . . . . . . . . . . 1-8

1.3.1 Facility Description ................. 1-9

1.3.2 Process Information ................. 1-9

1.3.3 Waste Characteristics ................ 1-9

1.3.4 Groundwater Monitoring .. . . . . . . . . . . . 1-9

1.3.5 Closure Performance Standards . . . . . . . . . . 1-9

1.3.6 Closure Activities .................. . 1-9

1.3.7 Modified Closure Care .. . . . . . . . . . . . 1-10

1.3.8 References ..................... 1-10 
GคWNロ

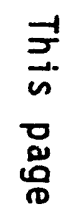

เ.

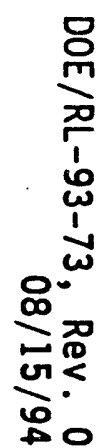




\subsection{INTRODUCTION}

This section provides a brief summary of the contents of each chapter of this plan for the closure of the 300 Area Process Trenches ( 300 APT) treatment, storage, and/or disposal (TSD) unit. It also provides background information for this unit and discusses how its closure will be integrated with the remedial action (RA) for the Comprehensive Environmental Response, Compensation, and Liability Act of 1980 (CERCLA) 300-FF-1 Operable Unit (OU).

\subsection{BACKGROUND}

The Hanford Site, located northwest of the city of Richland, Washington, houses reactors, chemical-separation systems, and related facilities used for the production of special nuclear materials, as well as for activities associated with nuclear energy development. Activities are centralized in numerically designated areas on the Hanford Site. One such area is the 300 Area located approximately 4.8 kilometers ( 3 miles) north of Richland.

The 300 APT is located within the 300 Area of the Hanford Site. This area contained reactor fuel fabrication facilities and research and development laboratories. The 300 APT was constructed and began operations in 1975 as the 316-5 Process Trenches. This unit remains in operation today as a surface impoundment for the disposal of process sewer effluent originating from verious operations within the 300 Area. This effluent arrives by way of the 300 Area process sewer system, which has been the sole source of effluent for the TSD unit. The 316-5 Process Trenches gained Resource Conservation and Recovery Act of 1976 (RCRA) interim status as the 300 APT TSD unit on November 11, 1985. Since 1985, the unit has been administratively closed to discharges of dangerous waste.

The 300 APT is scheduled to be permanently removed from service when piping to the unit is blanked off in December 1994 in support of the Hanford Federal Facility Agreement and Consent Order (Tri-Party Agreement) Milestone M-17-10 for Project L $045 \mathrm{H}$, Treated Effluent Disposal Facility (TEDF) (Ecology et al. 1994). This closure plan provides for unit closure that will be conducted pursuant to the final status standards of the Washington Administrative Code (WAC), "Dangerous Waste Regulations", WAC 173-303-610 and 40 Code of Federal Regulations (CFR) 270.1.

The 300 APT TSD unit is operated by the U.S. Department of Energy, Richland Operations office (DOE-RL) and managed by Westinghouse Hanford Company (Westinghouse Hanford). Although the U.S. Government holds legal title to this facility, the DOE-RL, for purposes of the RCRA, is considered the legal owner of the facility under existing U.S. Environmental Protection Agency (EPA) interpretive regulations (51 CFR 7722). 


\subsection{INTEGRATION OF RCRA AND CERCLA PROCESSES FOR CLOSURE OF THE 300 APT}

This section discusses the CERCLA RA process at the Hanford Site. It will discuss why and how the RCRA and CERCLA programs can achieve closure of the 300 APT TSD unit.

\subsubsection{CERCLA RA Process and TSD Unit Closure}

In 1989, pursuant to its authority under CERCLA, the EPA placed the 300 Area on the National Priorities List contained within Appendix $B$ of the National 0 il and Hazard Substances Pollution Contingency Plan. In 1989, the DOE-RL, Washington State Department of Ecology (Ecology), and the EPA issued the Tri-Party Agreement (Ecology et al. 1994) governing CERCLA RAs at the Hanford Site. The Tri-Party Agreement governs cleanup of Hanford Site areas under CERCLA regulations and identifies cleanup areas as OUs. The 300-FF-1 OU is one such ou that addresses waste and contaminated media within its boundaries. The 300 APT TSD unit is within the boundaries of the 300-FF-1 OU. Another OU is the 300-FF-5, which addresses 300 Aggregate Area groundwater concerns. The $300-F F-5$ OU is addressed in this pian because the operation of the TSD unit has affected groundwater. The CERCLA RA process for these sites as past-practice units is defined in the Tri-Party Agreement Action Plan (Sections 7.1 through 7.3) (Ecology et al. 1994).

The Tri-Party Agreement Action Plan also addresses the requirements of RCRA in guiding the closure of RCRA TSD units at the Hanford Site. CERCLA regulations normally only govern cleanup activities for sites contaminated before the effective date of RCRA regulations (i.e., November 19, 1980). However, in accordance with Section 3.3 and Appendix $B$ of the Tri-Party Agreement Action Plan, surface impoundments, such as the 300 APT RCRA TSD unit, are assigned to the past-practice oU that they are located in for investigation and management of closure activities. The 300 APT has been assigned to the $300-F F-1$ OU. This will ensure consistency of physical actions for the units (Ecology et al. 1994).

The regulatory agency for RCRA TSD units is ECology. The lead regulatory agency for CERCLA OUs is the EPA. However, as will be discussed later, regulatory responsibilities for this integrated activity will be shared by RCRA and CERCLA regulators.

The initial stage of a CERCLA site RA is the remedial investigation/feasibility study (RI/FS) process. The 300-FF-1 RI/FS process, under which the RCRA unit was investigated, was performed in accordance with Tri-Party Agreement Milestone M-15-03 using the EPA guidance provided in Guidance for Conducting Remedial Investigations and Feasibility Studies Under CERCLA (EPA 1988). The RI/FS process is shown in Figure 7-3 of the Tri-Party Agreement (Ecology et al. 1994). This process carries a CERCLA RA to the point of a record of decision (ROD) by CERCLA regulators. The ROD for the 300-FF-1 OU will reflect regulator decisions regarding CERCLA OU and TSD unit remediation methodology and cleanup levels. 
Preparation of the Phase III Feasibility Study Report for the 300-FF-1 Operable Unit, from which the ROD will evolve, occurs as the last step in the RI/FS process (DOE-RL 1994). The 300-FF-1 Phase III FS (DOE-RL 1994) identifies the dominant risk factors, screens remedial alternatives, and provides preliminary remediation goals (PRG) as numerical cleanup levels. The CERCLA documents completed in support of the RI/FS include the following:

- Remedial Investigation/Feasibility Study Work Plan for the 300-FF-1 Operable Unit, Hanford Site, Richland, Washington (DOE-RL 1990)

- Phase I Remedial Investigation Report for the 300-FF-1 Operable Unit (DOE-RL 1992d)

- Phase I and II Feasibility Study for the 300-FF-1 Operable Unit (DOE-RL 1992e)

- Phase II Remedial Investigation Report for the 300-FF-1 Operable Unit (DOE-RL 1993C)

- Phase I Remedial Investigation Report for the 300-FF-5 Operable Unit (DOE-RL 1993b)

- Expedited Response Action Assessment for the 316-5 Process Trenches(DOE-RL 1992a)

- Phase III Feasibility Study Report for the 300-FF-1 Operable Unit(DOE-RL 1994).

Implementation of the ROD is divided into three phases. These phases and their primary documents are described in Sections 7.3.9 through 7.3.11 of the Tri-Party Agreement Action Plan (Ecology et al. 1994). The phases are the remedial design (RD) phase, the RA phase, and the operation and maintenance (O\&M) phase. The primary documents required for these phases are the Remedial Design Report (RDR), Remedial Action Work Plan (RAWP), and the 0\&M Work Plan. All of these documents require regulator approval. A more detailed list of CERCLA RA documents is presented in Table 9-3 of the Tri-Party Agreement Action Plan (Ecology et al. 1994). The schedule for each phase will be included in its primary document and reflected in the oU work schedule located in Appendix D of the Tri-Party Agreement Action Plan (Ecology et al. 1994).

The RA phase and the RAWP will provide the detailed information required to implement actions developed under the RD for remediation at the TSD unit site. This information will include remediation methodology, cleanup levels, waste management and disposal methods, and sampling and analysis. The 0\&M phase and the 0\&M Plan will provide information regarding site inspections, monitoring, and maintenance required after remediation activities. 


\subsubsection{Closure Plan Format}

The Phase III FS report (DOE-RL 1994) is due to CERCLA regulators August 15, 1994, in accordance with Tri-Party Agreement Milestone M-15-03C. This closure plan is due to RCRA regulators August 15, 1994 in accordance with Tri-Party Agreement Milestone M-20-32 (Ecology et al. 1994).

The RCRA closure plan is separate but coordinated with CERCLA documents. The closure plan discusses how CERCLA OU remedial options integrate with TSD unit closure options presented in regulations governing RCRA closures while meeting the requirements of WAC 173-303-610. Much of the TSD unit information required to satisfy WAC 173-303-610 closure plan content requirements (e.g., background information, TSD unit description, waste inventory) is taken from published CERCLA documents for the 300-FF-1 OU RI/FS process.

Information required for Chapters 6.0 (Closure Strategy) and 7.0 (Closure Activities) of the closure plan that is not available from published CERCLA predecessor documents, is obtained through coordination with the concurrently developing CERCLA Phase III FS Report (DOE-RL 1994). The CERCLA 300-FF-1 RA activities in support of TSD unit closure will be incorporated into the closure plan by RCRA Closures during revision intervals coordinated with the CERCLA review process presented in Figure 9-1 of the Tri-Party Agreement Action Plan (Ecology et al. 1994).

\subsubsection{Basis for RCRA/CERCLA Integration}

The RCRA/CERCLA integration for closure of the 300 APT TSD unit is being pursued as a Tri-Party Agreement-driven activity that is physically appropriate and programmatically feasible.

\subsubsection{Physical Appropriateness. The integration of RCRA and CERCLA} activities for closure of the 300 APT ensures physical consistency of RCRA and CERCLA unit activities in the protection of human health and the environment. Integration capitalizes on CERCLA's prior history of 300 APT remediation. It also allows the TSD unit cleanup to use the same cleanup levels, remediation technology, and waste handling methods as the ou to capitalize on the economies of a one-time, larger scale CERCLA OU operation.

The Tri-Party Agreement Action Plan requires that the closure of TSD units must consider all hazardous substances, including radionuclides. The Tri-Party Agreement Action Plan allows that radionuclides not addressed under TSD unit closure be addressed under CERCLA authority. The OU will address pervasive radionuclides at the TSD (Chapter 4.0, Section 4.3.3) in a manner that will also effectively mitigate risk from dangerous waste constituents (DOE-RL 1994). Integration of the two units' activities will ensure adherence to the Tri-Party Agreement Action Plan requirements regarding cleanup of all hazardous substances.

The CERCLA group and CERCLA regulations have a history of involvement with 300 APT TSD unit remediation dating from the 316-5 Process Trenches ERA in 1991. The ERA was performed under CERCLA authority with regulator approval 
to mitigate environmental hazards and to facilitate the RI/FS process for the 300-FF-1 OU CERCLA RA. The ERA is discussed in detail in Chapter 2.0, Section 2.4. The CERCLA OU involvement in 300 APT remediation will continue after the TSD has ceased operations as a logical extension of prior remedial activities at the TSD unit.

If treatment by soilwashing is the selected remedial alternative, this activity will integrally bind both units to the use of the same cleanup levels and waste disposal methods. The soilwashing unit will be remediating both RCRA and CERCLA unit soils simultaneously and the remediated soils will be used interchangeably as backfill for both units. Separation of the treatment waste or product according to unit will not be practical.

Activity integration is enhanced by coinciding submittal dates of August 15, 1994 for the RCRA closure plan and the Phase III FS Report (DOE-RL 1994) presented in the Tri-Party Agreement, Appendix D (Ecology et al. 1994). The closure plan approval schedule presented in Figure 9-2 of the Tri-Party Agreement Action Plan coordinates with the scheduled arrival date of the ROD of September 1995. This is also the approximate due date to regulators of Revision 1 of the closure plan. Regulator familiarization with closure strategy during this period should allow remediation to proceed under TSD unit interim status authority before closure plan approval, with prior notification to Ecology.

1.2.3.2 RCRA and CERCLA Program Equivalency. The WAC 173-303-610 closure process and the CERCLA RA process are functionally equivalent and interchangeable for TSD unit closure purposes. Functional equivalency ensures equal protection of human health and the environment even where the units' processes may be different. One difference is that CERCLA uses the risk assessment methodology of Hanford Site Baseline Risk Assessment Methodology (HSBRAM) to identify contaminants of concern and to calculate cleanup levels based on risk. Another difference is in waste management practices, which is discussed in Section 1.2.5.

Both units processes are regulatorily directed to consider protection of human health and the environment and adhere to appropriate state and federal regulation as threshold criteria in making RA decisions. Section 121 of CERCLA requires adherence to applicable and relevant and appropriate regulations (ARAR). The ARARs applicable to this RA include "Dangerous Waste Regulations" (WAC 173-303), Model Toxics Control Act (MTCA) Method C cleanup levels (WAC 173-340), and surface water standards of WAC 173-201A (DOE-RL 1994). In accordance with WAC 173-303-610, the closure plan al so must reflect adherence to state and federal laws in closing the unit to meet performance standards for protection of human health and the environment, minimization of future maintenance, and return of the land to maximum usefulness. Further, both units share the requirement for approval by their respective regulators of RA documentation.

The RCRA and CERCLA processes provide essentially the same information in documenting how their units will be closed. The closure plan identifies how closure will be conducted, estimated maximum inventory of waste (i.e., nature and extent of contamination), and, the methods for removal, transport, 
treatment, storage, and disposal of contaminated unit media. Also required for RCRA surface impoundments is information regarding unit maintenance and monitoring if waste is left in place after closure. The CERCLA RI/FS site characterization and risk assessment are providing this information by identifying TSD unit contaminants of concern, volumes of contaminated media, RA objectives, and remedial alternatives. Other CERCLA considerations equating to RCRA performance standards of WAC 173-303-610, are short- and long-term effectiveness, reduction in toxicity, mobility and volume, and implementability and cost.

Both units calculate cleanup levels using methodology that provides equivalent protection of human health and the environment. The RCRA process implements the MTCA formulas for the calculation of health-based levels (HBL) through WAC 173-303-610. The CERCLA process uses HSBRAM risk assessment methodology to establish cleanup levels for soil and groundwater appropriate to a conservative calculation of actual risk. The HSBRAM formulas for calculating soil HBLs are taken from MTCA (DOE-RL 1992c) and are equally protective of human health and the environment. Consequently, HSBRAM methodology should be acceptable for use in support of TSD unit closure.

The RCRA closure process and the CERCLA RA process al so share the requirement of approval by their respective regulators. Ecology must approve the closure $\mathrm{plan}$ and the EPA must approve primary RA documents

(Section 1.2.1). The OU and TSD final remedial alternative and the specific cleanup goals are approved through presentation in the Proposed PIan and the ROD originating from CERCLA regulators. However, the ROD specifications should be arrived at through coordinated decisionmaking by Ecology and the EPA.

\subsubsection{RCRA and CERCLA Regulator Interface}

Under the lead regulatory agency concept described in Section 5.6 and Appendix C of the Tri-Party Agreement Action Plan (Ecology et al. 1994), the EPA is the lead regulatory agency for this integrated activity. The EPA is responsible for overseeing the activities covered by the Tri-Party Agreement Action Plan, including approval of RA documents, preparation of a ROD, and ensuring that the requirements of the Tri-Party Agreement Action PIan are met. However, the EPA and Ecology will each retain their respective legal authorities and shall make decisions on action to be taken pursuant to those authorities (Ecology et al. 1994). The TSD unit closure must satisfy RCRA regulators because ensuring and documenting TSD closure to WAC 173-303-610 performance standards is the responsibility of the RCRA regulators and the RCRA closure plan. To ensure this, CERCLA unit actions must consider RCRA closure requirements and the closure plan must accurately document planned CERCLA RAs at the TSD unit.

The effectiveness of RCRA and CERCLA integration for closure of the TSD unit will remain dependent on the continued communication and teamwork of RCRA and CERCLA unit workers and regulators to the point of final TSD unit closure. In accordance with the Tri-Party Agreement Action Plan (Sections 8.1 and 8.2), TSD unit and OU project and unit managers will meet regularly to discuss 
progress, address technical and regulatory issues, and review activity plans for their respective units. The effort to coordinate regulator decisionmaking will rely on this system of compulsory meetings. RCRA regulators shall be informed of CERCLA unit meetings for proposes of involvement in the decisions pertaining to the RCRA unit closure and shall be placed on distribution for CERCLA information and documents pertaining to the RCRA unit closure. CERCLA unit managers shall also be informed of RCRA unit meetings and be placed on distribution of information pertaining to the RCRA unit closure. RCRA regulators must also be integrally involved with the CERCLA data quality objective (DQO) process for sampling performed by the OU at the TSD unit.

\subsubsection{RCRA Permitting Considerations and Regulator Agreements}

This section discusses RCRA permitting considerations and regulator agreements for implementation of this integrated closure.

1.2.5.1 RCRA Permitting Considerations. If soilwashing (i.e., onsite soil treatment) is the selected remedy, it will be-performed outside of the TSD unit boundaries, but will remain within the 300-FF-1 OU. Consequently, the TSD unit Part $A$ forms will not require revision to reflect new onsite treatment. Further, the treatment unit requires no RCRA permit because it will be a portion of an RA pursuant to the authority of CERCLA, performed on a CERCLA site. The treatment unit would still remain subject to the substantive requirements deemed as ARARs [e.g., quantitative health-or risk-based restrictions such as maximum contaminant levels (MCL)] without requiring any additional federal, state, or local permit.

1.2.5.2 Regulator Agreements. Administrative and substantive differences can exist between RCRA and CERCLA regulations regarding the management and disposal of dangerous waste. For example, the WAC-173-200 90-day waste accumulation limit is a RCRA administrative limit that is not pertinent to CERCLA onsite actions. The CERCLA unit will manage TSD unit waste simultaneously with OU waste. The CERCLA unit intends to dispose of all waste at the Environmental Restoration Disposal Facility (ERDF) as remediation waste. However, the ERDF currently cannot accept dangerous TSD unit closure waste. Regulator agreements will be required for acceptance of TSD unit closure waste by the ERDF.

Both units' regulators can agree through the ROD that all waste generated by CERCLA during the 300-FF-1 OU RA, including TSD unit closure waste, is remediation waste and can therefore be disposed of at the ERDF. Technical standards and maintenance and institutional controls will be required for the ERDF. These provisions ensure that the ERDF disposal offers protection of human health and the environment for TSD unit waste equivalent to disposal in a RCRA permitted unit or containment in the 300 Area.

If regulators do not designate TSD unit closure waste as remediation waste, other agreements will be required to allow its disposal at the ERDF. These agreements must recognize that TSD unit waste, although containing contamination above clean closure levels, does not designate as dangerous waste under WAC 173-303 and exists in unit soils at concentrations below MTCA 
residential, health-based cleanup levels. As proposed in Chapter 4.0, Section 4.3.1 and based on Ecology guidance (Eaton 1993), a contained-in determination will be sought from regulators that will remove the listing from pre-treatment soils. This will allow disposal at the ERDF with or without soil treatment.

\subsubsection{RCRA Group Responsibilities}

To ensure that the CERCLA activities result in a riable TSD unit closure, RCRA document preparers and/or regulators will do the following:

- Ensure that the TSD unit Part A permit application Form 3 is true, accurate, ant complete

- Prepare a closure plan that provides for closure satisfying all WAC 173-303-610 closure performance standards

- Remain involved with the decisionmaking processes for CERCLA unit activities to effectively concur with the ou

- Remediation activities for the TSD unit

- Waste management methodology (to ensure that RCRA unit waste is managed and disposed of in a RCRA-equivalent manner)

- Cleanup levels that are shared with the TSD unit

- Sampling that will verify the absence of contamination to the specified cleanup levels at the TSD unit

- Post-remediation inspections, maintenance, and monitoring (including groundwater monitoring)

- Update the closure plan to reflect changes in CERCLA activities that affect the TSD unit

- Provide $c$ tification that the TSD unit was closed in accordance with the closure plan.

\subsection{APT CLOSURE PLAN CONTENTS}

The 300 APT closure plan presents a description of the 300 APT TSD unit, the history of waste managed, and the approach that will be followed to close the unit. The 300 APT closure plan consists of nine chapters as follows:

- Introduction (Chapter 1.0)

- Unit Description (Chapter 2.0)

- Process Information (Chapter 3.0)

- Waste Characteristics (Chapter 4.0)

- Groundwater Monitoring (Chapter 5.0) 
- Closure Performance Standards (Chapter 6.0)

- Closure Activities (Chapter 7.0)

- Modified Closure Care (Chapter 8.0)

- References (Chapter 9.0). sections.

A brief description of each chapter is provided in the following

\subsubsection{Facility Description (Chapter 2.0)}

This chapter provides a brief description of the Hanford Site and the location and description of the 300 APT. Information on Hanford Site security also is provided.

\subsubsection{Process Information (Chapter 3.0)}

This chapter describes how the 300 APT processed waste and explains the overall waste treatment system.

\subsubsection{Waste Characteristics (Chapter 4.0)}

This chapter discusses the waste inventory and characteristics of the waste treated at the 300 APT. It also describes the contamination remaining in TSD unit soils and the risks from this contamination.

\subsubsection{Groundwater Monitoring (Chapter 5.0)}

This chapter discusses the current groundwater monitoring program established to characterize and monitor groundwater contamination in the area of the 300 APT.

\subsubsection{Closure Performance Standards (Chapter 6.0)}

This chapter discusses the closure strategy, performance standards for protection of health and the environment, and the steps to unit closure.

\subsubsection{Closure Activities (Chapter 7.0)}

This chapter discusses the physical remedial activities required to implement closure strategy and the sampling and analysis required to verify closure. This chapter also presents a closure schedule and closure certification. 
1.3.7 Modified Closure Care (Chapter 8.0)

This chapter outlines closure care provisions if this TSD unit, as anticipated, enters a modified closure care period before final closure.

\subsubsection{References (Chapter 9.0)}

References cited throughout this closure plan are listed in this chapter. Al1 references listed here, which are not available from other sources, will be made available for review, upon request, to any regulatory agency or public commentor. References can be obtained by contacting the following.

Administrative Records Specialist

Public Access RoOm H6-08

Westinghouse Hanford Company

P.0. Box 1970

Richland, Washington 99352 


\section{CONTENTS}

2.0 FACILITY DESCRIPTION . . . . . . . . . . . . . . . . 2-1

2.1 GENERAL HANFORD SITE DESCRIPTION ............... 2-1

2.2 HANFORD SITE RCRA FACILITY DESCRIPTION . . . . . . . . . . . . . $2-1$

2.3300 APT UNIT DESCRIPTION . . . . . . . . . . . . . . 2-1

$2.4316-5$ PROCESS TRENCHES ERA ................... . $2-2$

2.5 SECURITY INFORMATION ....................... . . . 24

2.5.1 24-Hour Surveillance . . . . . . . . . . . . . . . . 2-4

2.5.2 Barrier and Means to Control Entry . . . . . . . . 2-4

APPENDIX

2A PHOTOGRAPHS ........................ APP 2A-1

FIGURES

2-1. Hanford Site........................ . F2-1

2-2. 300 APT ........................... . F2-2

2-3. 300 Area . . . . . . . . . . . . . . . . . . . . F2-3

2-4. 300-FF-1 OU . . . . . . . . . . . . . . . . . . . . . . . . . . . F2-4

2-5. 300 APT Elevation Contouring . . . . . . . . . . . . . . . . . . F2-5

2-6. 300 APT Elevation Section View . . . . . . . . . . . . . . . . . . F2-6

2-7. 316-5 Pre- and Post-Excavation Sampling Locations . . . . . . . . F2-7 
DOE/RL-93-73, Rev. 0

08/15/94

This page intentionally left blank. 
DOE/RL-93-73, Rev. 0

$08 / 15 / 94$

\subsection{FACILITY DESCRIPTION}

This chapter provides a brief description of the Hanford Site and the 300 APT TSD unit. Information on Hanford Site security also is provided.

\subsection{GENERAL HANFORD SITE DEOCRIPTION}

In early 1943, the U.S. Army Corps of Engineers selected the Hanford Site as the location for reactor, chemical separation, and related activities for the production and purification of plutonium. The Hanford Site (Figure 2-1) covers approximately 1,450 square kilometers ( 560 square miles) of semiarid land located adjacent to the city of Richland, Washington.

\subsection{HANFORD SITE RCRA FACILITY DESCRIPTION}

The Hanford Facility is a single RCRA facility identified by the EPA/State Identification Number WA7890008967 that consists of over 60 TSD units conducting dangerous waste management activities. These TSD units are included in the Hanford Facility Dangerous Waste Part A Permit Application (DOE-RL 1988). The Hanford Facility consists of all contiguous 1 and and structures, other appurtenances, and improvements on the land used for recycling, reusing, reclaiming, transferring, storing, treating, or disposing of dangerous waste, which, for the purposes of the RCRA, is owned by the U.S. Government and operated by the DOE-RL (excluding land north and east of the Columbia River, river islands, land owned or used by the Bonneville Power Administration, land leased or under lease obligation to the Washington Public Power Supply System, and 1 and owned by or leased to Washington State).

\subsection{APT UNIT DESCRIPTION}

The 300 APT unit (Figure 2-2) entered operations March 16, 1975. This unit is scheduled to be removed from service in December 1994. This unit is located within the 300 Area (Figure 2-3) of the Hanford Site. The unit is approximately 61 meters $(200$ feet) north of the main 300 Area perimeter fence and approximately 300 meters (1,000 feet) west of the Columbia River. The unit is also within the boundary of the 300-FF-1 CERCLA OU (Figure 2-4). The 300 APT is located above the 300-FF-5 groundwater OU, which encompasses all 300 Area groundwater.

The 300 APT is surrounded by its own 1.8-meter (6-foot) metal wire fence that defines the boundaries of the unit requiring RCRA closure. The unit includes approximately 6.1 meters (20 feet) of process sewer piping to the unit fence. However, for purposes of RCRA remediation, the boundary of the unit is described by the extent of contamination from RCRA unit constituents (WAC 173-303-650). The extent of RCRA contamination will be discussed in Chapter 4.0, Section 4.3. The fence has one locked gate at the south end of the unit and is posted with warning signs. The area from the TSD unit fence to the edge of the trenches is unpaved, naturally vegetated terrain approximately 2 meters ( 6 feet) higher than the top of the berm. 
The 300 APT currently consists of two parallel, unl ined trenches running north and south separated by a narrow earthen berm (Appendix 2A, Figure 2A-2). The east trench is approximately 366 meters (1,200 feet) long and the west trench is approximately 344 meters (1,130 feet) long. Both trenches are approximately 3.5 meters ( 11 feet) deep, 3 meters (10 feet) wide at the bottom, and 10 meters (32 feet) wide at the top. Trench bottoms slope gently to the north and are approximately 3.4 meters (11 feet) above the water table. Until 1991, there was a 30 by 50 by 3 -meter ( 90 by 150 by 9 -foot) depression located at the northwest corner of the west trench. This area received effluent because of slope failure. In 1990, the depression was separated from the west trench by a berm needed to support a birdscreen placed over the trench. The north 91 meters ( 300 feet) of the original trenches, including the depression, are now an impoundment area for covered low-level radioactive and low-level, mixed waste soils. Elevational contouring of the trenches, as currently configured, is presented in Figure 2-5.

A concrete weir box is located at the south end of the TSD unit. Process sewer effluent reaches the unit through 24-inch-diameter 300 Area Process Sewer System (PS) piping that is connected to the weir box. The weir box measures 21.3 meters ( 70 feet) long (east/west), 3 meters (10 feet) high, and 3 meters (10 feet) wide. The box has two sluice gates that, in the past, allowed the trenches to be operated alternately. In 1992, the west trench was permanently removed from service and now only the east trench receives effluent. Effluent flows through the east gate, down a concrete apron, and into the trench (Figure 2-6). There is no effluent outlet; all water either infiltrates the soil column or evaporates.

The trenches were designed to dispose of up to $11,370,000$ liters ( 3 million gallons) of effluent per day, but now receive only approximately $1,900,000$ liters $(500,000$ gallons) per day. At present, the liquid discharging to the east trench extends only about 6 meters ( 20 feet) from the weir box before percolating into the soil.

From the beginning of operations in 1975 until October 1993, a continuous, composite sampler was located at the headwork to analyze PS effluent at the point of discharge to the environment. Since 1993, process sewer effluent has been analyzed by a sampler located outside the unit. The results of effluent sampling are discussed in Chapter 3.0 .

\section{$2.4 \quad 316-5$ PROCESS TRENCHES ERA}

In 1991, at regulator request, an expedited response action (ERA) was undertaken at the 316-5 Process Trenches (300 APT). This action arose from regulator concerns based on analytical results of trench sampling performed in 1986. These sampling results are reported in Table 15 of the RI/FS Work PIan for the 300-FF-1 OU (DOE-RL 1990). The data identified the presence of radioactive and inorganic contaminants (primarily heavy metals) in the trench soil at levels potentially harmful to groundwater and to the nearby Columbia River. These data were used only to guide ERA planning. The ERA is presented as a portion of the unit description because it changed the physical 
configuration of the unit along with changing contaminant distribution within the unit.

The ERA was undertaken under the authority of the Tri-Party Agreement Action Plan (Section 6.4) as an interim action pending final cleanup activities for the 300-FF-1 OU (Ecology et al. 1994). ERA planning is documented in the Expedited Response Action Proposal for the 316-5 Process Trenches (DOE-RL 1991a) and ERA results are documented in the Expedited Response Action Assessment for the 316-5 Process Trenches (DOE-RL 1992a).

The ERA objective was to reduce the potential migration of contaminants to groundwater. The specific ERA goal was to reduce the measurable level of radiation in the trenches to less than three times the upper tolerance limit of background. This was accomplished by removing contaminated sediments, using them to fill in the north end of the trenches, and immobilizing them. The process of mitigating the risk presented from pervasive radionuclides also mitigated the threat from the dangerous, inorganic constituents.

Until the ERA, the trenches were approximately 457 meters (1,500 feet) long, 3 meters ( 10 feet) wide at the bottom, and 9 meters ( 30 feet) wide at the top with a 27 by 46 by 2.7 -meter ( 90 by 150 by 9 -foot)-deep depression existing at the northwest corner of the west trench (Appendix 2A, Figure 2A1). The ERA uniformly excavated about 0.3 meter ( 1 foot) of chemically and radioactively contaminated soil from the sides and about 1.3 meters ( 4 feet) from the bottoms of each trench. ERAs physically changed the configuration of the trenches to their current length, depth, and width, lowered the berm, and filled in the depression (Appendix $2 A$, Figure 2A-2).

Approximately 5,400 cubic meters (7,000 cubic yards) were removed from each trench and relocated within the TSD unit according to their level of radioactivity. The less radioactively contaminated sediments (less than 2,000 counts per minute) were relocated to the north end of each trench. The more radioactively contaminated sediments (greater than 2,000 counts per minute) were consolidated in the depression located at the northwest corner of the west trench. Contaminated sediments at the depression were isolated from the effluent and then covered with a plastic barrier and a layer of clean aggregate. Areas that received excavated process trench materials are identified in this closure plan as the spoils areas.

As a portion of the ERA, pre- and post-excavation samples were taken as shown in Figure 2-7. These sampling activities are described in Section 3.3 of the ERA Assessment (DOE-RL 1992a). ERA sampling results are summarized in Appendix 7D. The results of ERA sampling were used by the 300-FF-1 CERCLA RI/FS as the basis for TSD unit risk assessment. These results indicate that the ERA successfully reduced trench contamination at all areas of the trenches other than the spoils areas. Con amination remaining at the trenches after the ERA is discussed in Chapter 4.0 . 


\subsection{SECURITY INFORMATION}

The following sections describe the 24-hour surveillance system and entry-control measures that provide security and restrict access to the 300 APT.

\subsubsection{4-Hour Surveillance}

The entire Hanford Site is a controlled-access area. The Hanford Site maintains around-the-clock surveillance to restrict unauthorized access for the protection of the public and of government property, classified information, and special nuclear materials. The Hanford Patrol maintains a continuous presence of protective force personnel to provide Hanford Site security.

\subsubsection{Barrier and Means to Control Entry}

Within the Hanford Site are operational areas to which access is restricted. The 300 Area is one such operational area and is the location of the 300 APT TSD unit. There is no staffed checkpoint through which access to the 300 Area or to the 300 APT TSD unit is gained. However, unknowing entry by individuals to the 300 Area, and subsequently to the vicinity of the unit, is administratively prevented by postings on access roads that allow authorized access only. Authorized personnel are those individuals with a DOE-issued security identification badge indicating the appropriate authorization. Such personnel are subject to a search of items carried into or out of these areas.

To preclude unknowing access into the TSD unit and to minimize the possibility of entry by animals or by unauthorized individuals, the unit is completely surrounded by a 1.8-meter $(6$-foot)-high, metal wire fence. The fence has one locked gate at the south end of the unit. Also, posted at the unit are placards that read "Danger - unauthorized personnel keep out." 


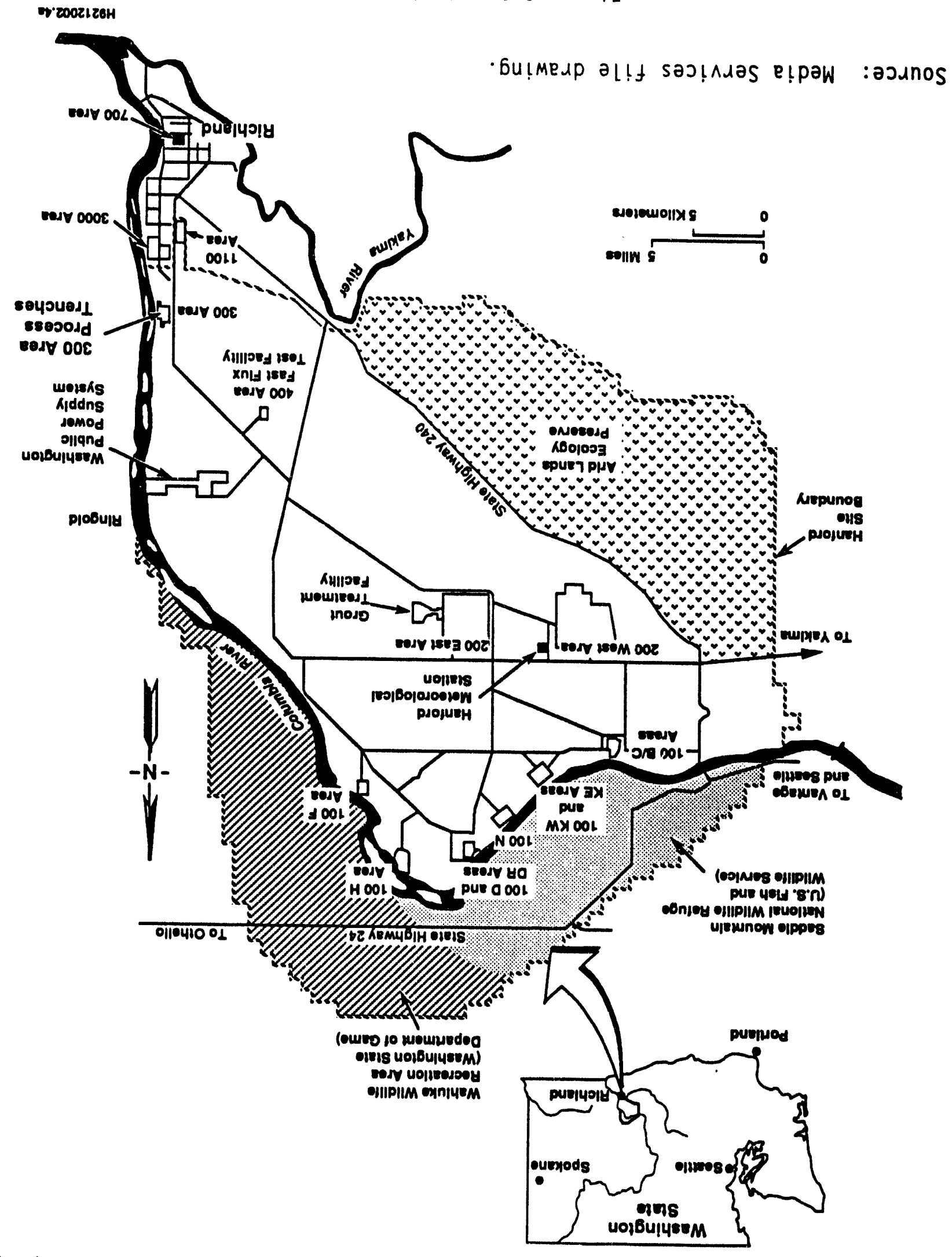

-әq!S pגofueH ' $[-2$ aגn5!

$66 / \mathrm{s} I / 80$

$0 \cdot \wedge$ 'әу $\varepsilon L-\varepsilon 6-7 y / 300$ 


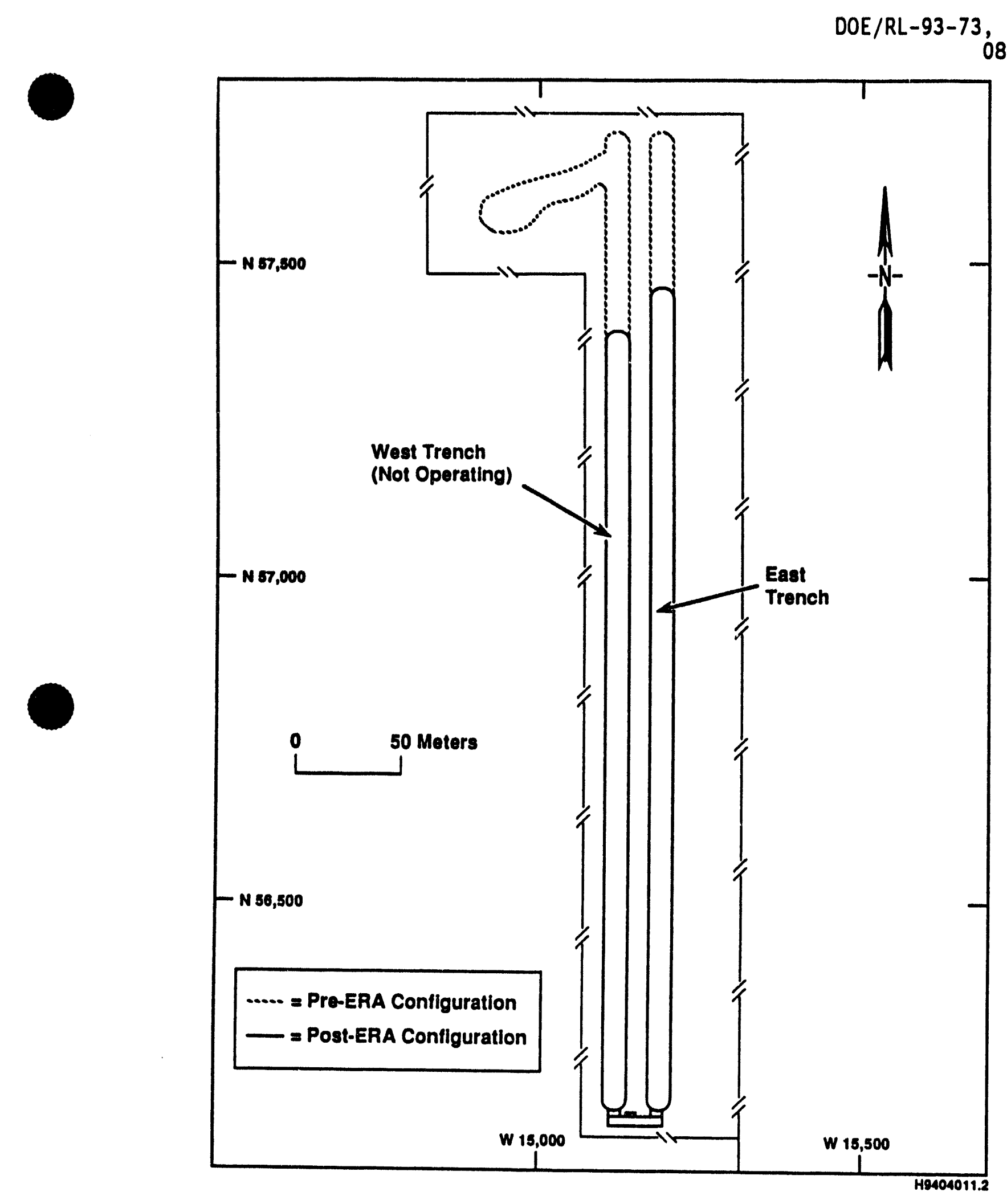

Source: Generated for closure plan from DOE-RL 1992a.

Figure 2-2. 300 APT, Pre- and Post-ERA. 


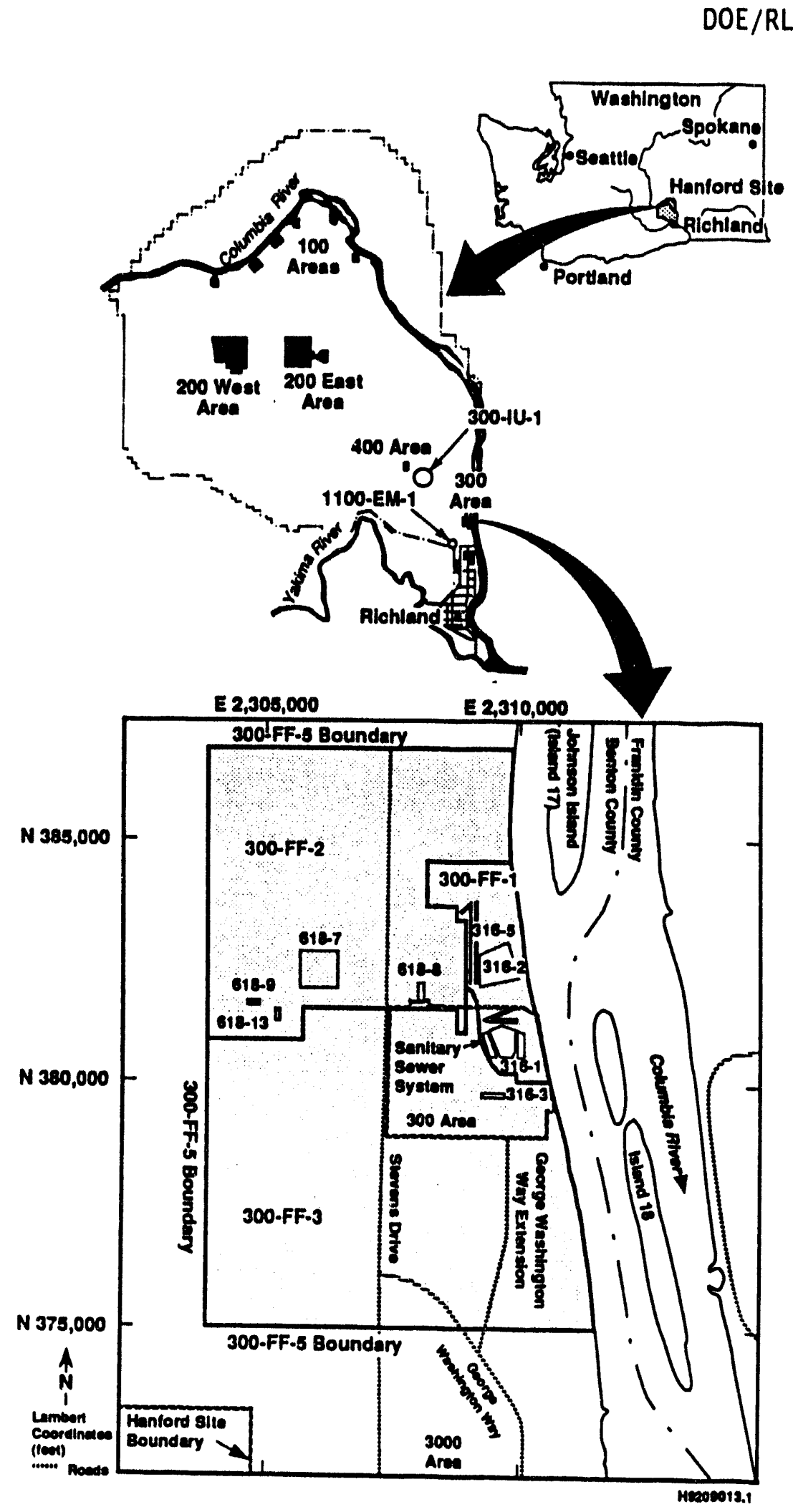

Source: Media Services file drawing.

Figure 2-3. 300 Area. 

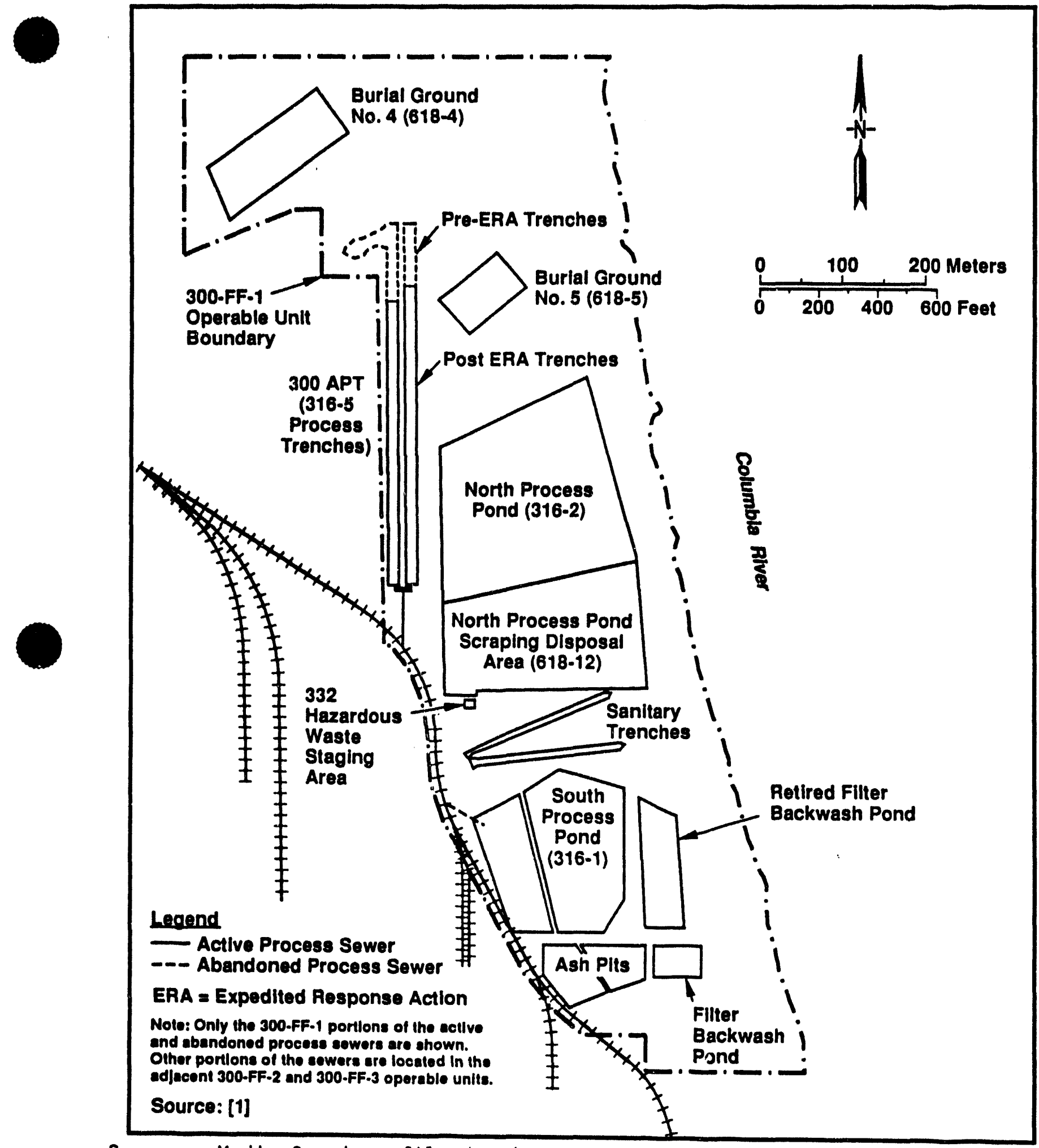

Source: Media Services file drawing.

H9403028.1

Figure 2-4. 300-FF-1 0U. 

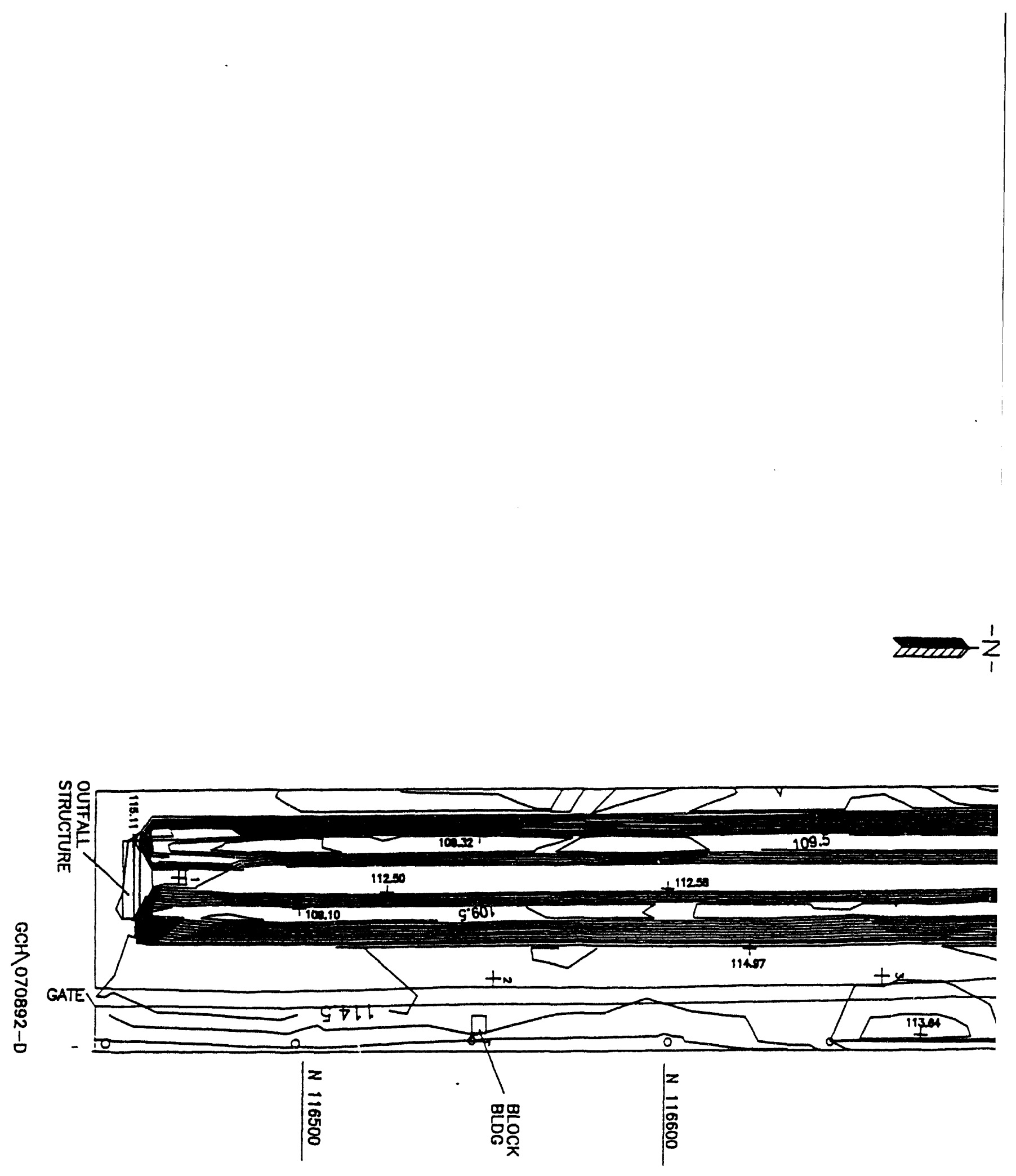

Note: Elevation is in meters.

Source: DOE-RL 1992a. 


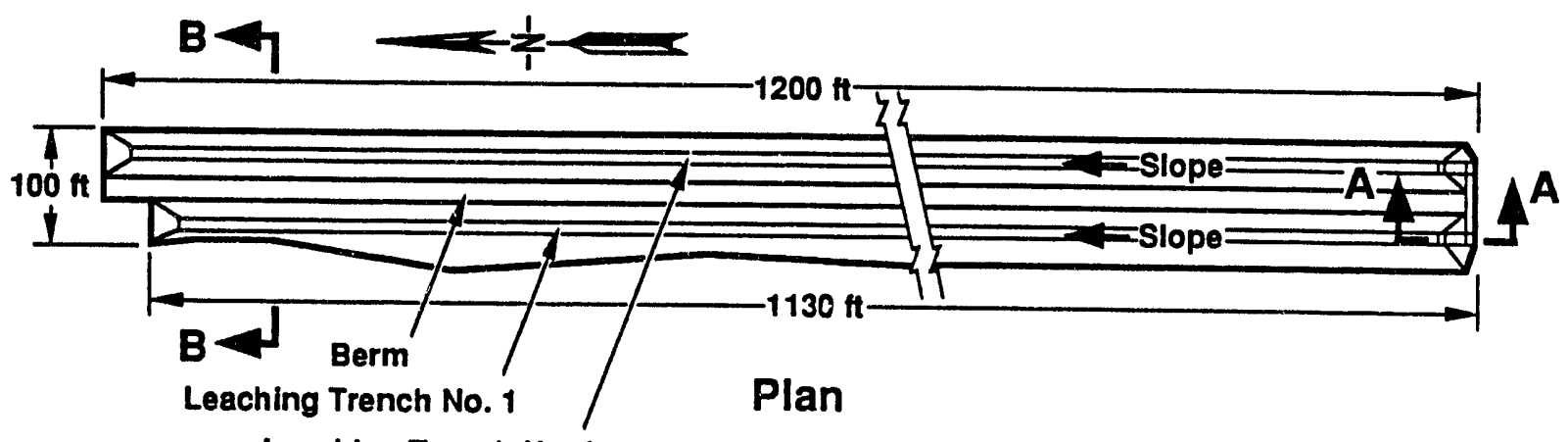

Leaching Trench No. 2

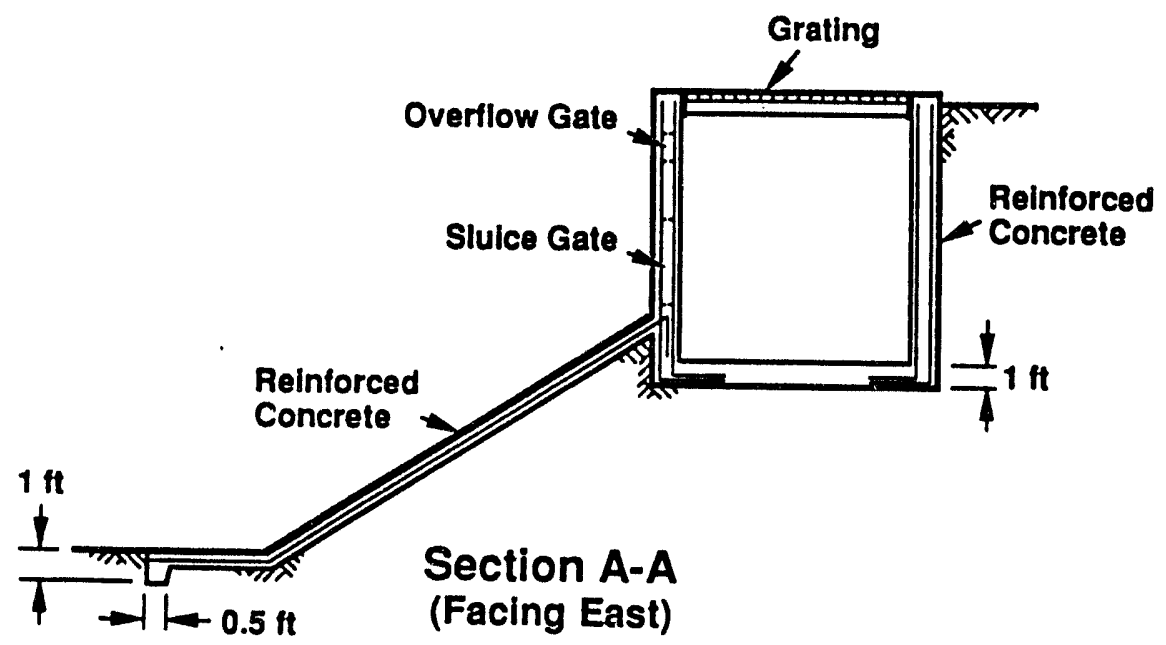

Not to Scale

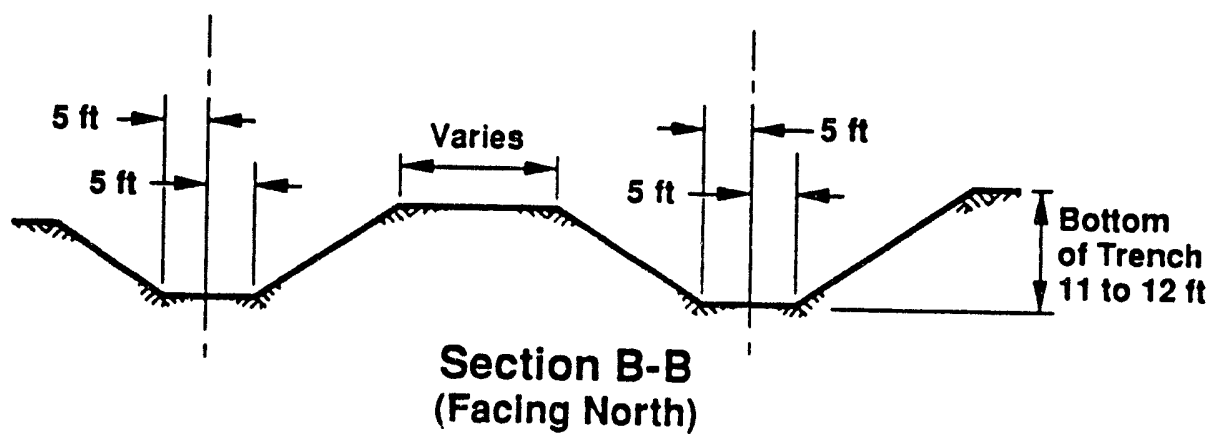

Source: WHC 1988b.

Figure 2-6. 300 APT Elevation Section View. 


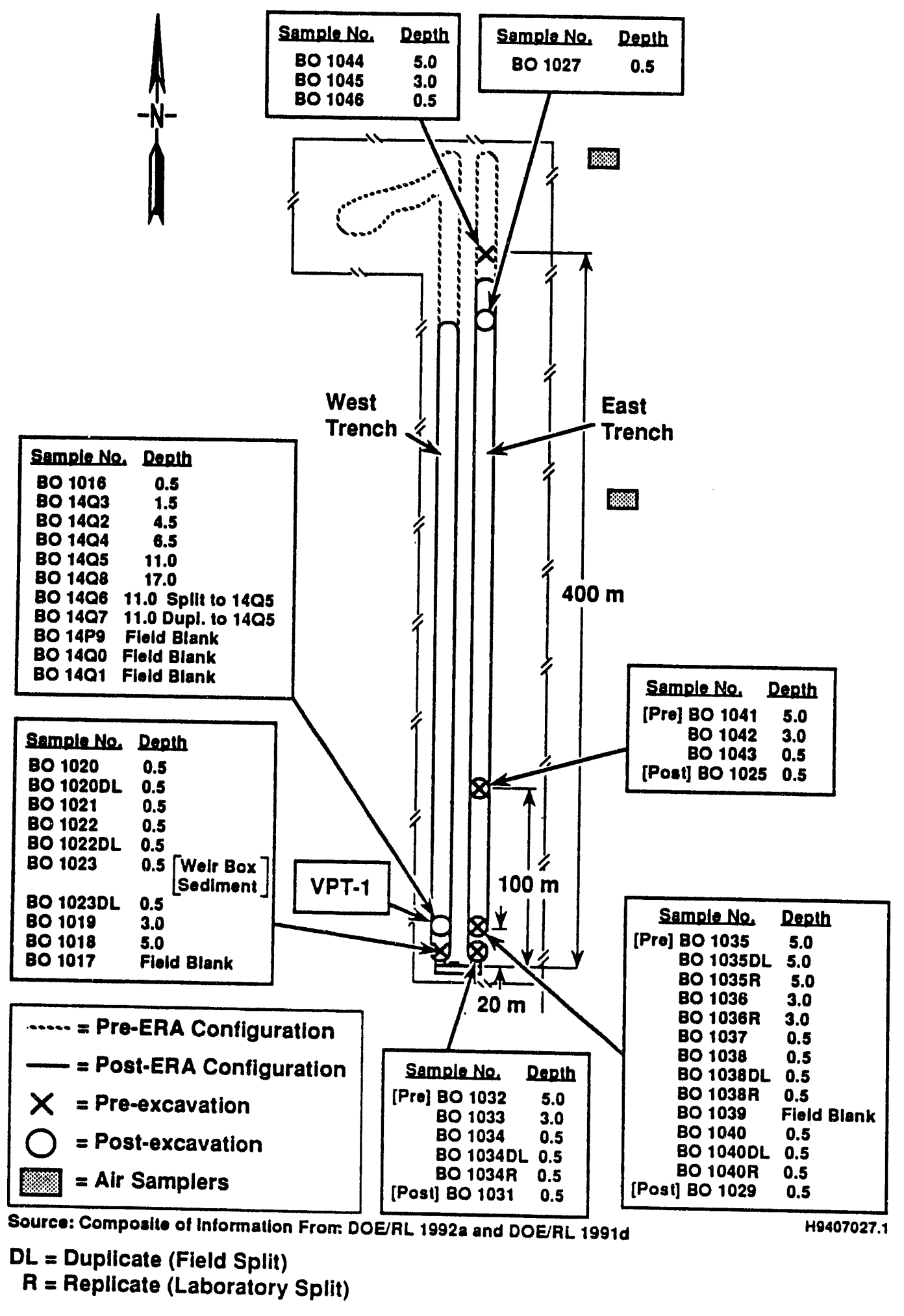

Figure 2-7. 316-5 Pre- and Post-Excavation Sampling Locations. 


\section{CONTENTS}

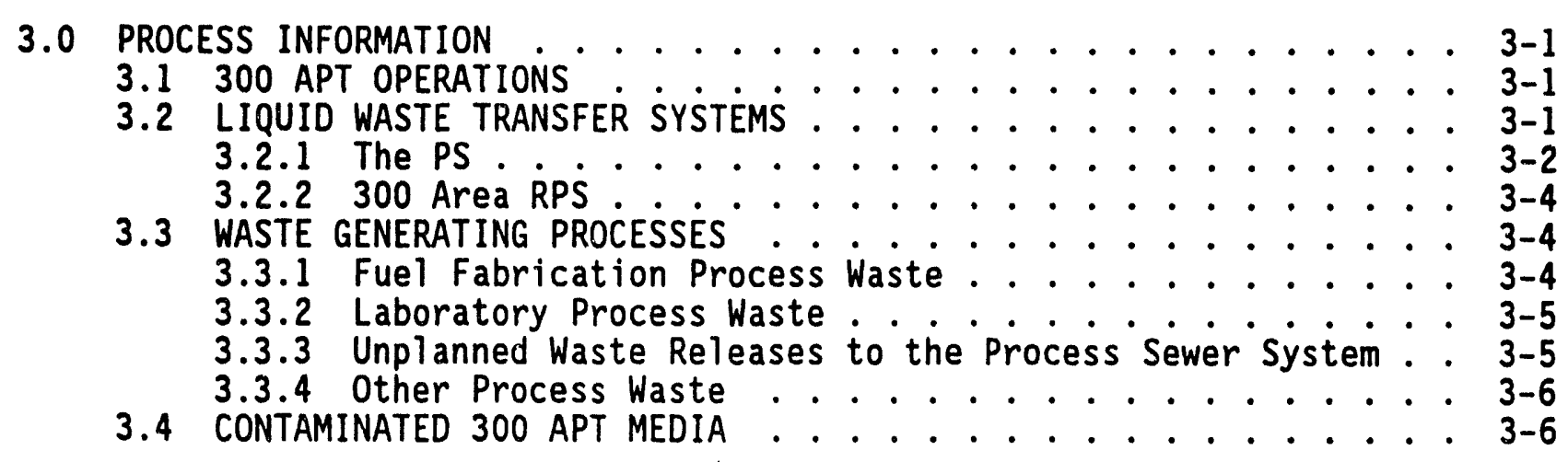

\section{FIGURE}

3-1. Liquid Waste Transfer Systems Schematic ............ . F3-1

\section{TABLES}

3-1. Index of Facilities Connected to the PS on November 16, $1993 \ldots$. T3-1

3-2. Flow History for the PS . . . . T3-2

3-3. Occasions when the PS Exceeded Drinking Water Standards at the

Point of Release to the Environment . . . . . . . . . . T3-3

3-4. Estimated Nonradiological Chemical Waste Inventory for

the Process Trenches . . . . . . . . . . . . . T3-4

3-5. Fuel Fabrication Chemicals and Radionuclides . . . . . . T3-5 
DOE/RL-93-73, Rev. 0

$08 / 15 / 94$

1
2
3
4
5

This page intentionally left blank. 


\subsection{PROCESS INFORMATION}

This chapter describes current 300 APT TSD unit operations. It also identifies the 300 Area processes that generated radioactive and dangerous waste and the liquid waste transfer systems that carried process waste.

\subsection{APT OPERATIONS}

Process sewer effluent reaches the unit through 24-inch-diameter PS piping that is connected to a concrete weir box located at the south end of the TSD unit. The box has two sluice gates that in the past allowed the trenches to be operated alternately. Effluent was delivered to one trench for 4 to 6 months or until it rose to an operationally determined level; it was then diverted to the other trench. Now, only the east trench receives effluent. Effluent flows through the east gate, down a concrete apron, and into the trench at a rate of approximately 1,900,000 liters (500,000 gallons) per day. There is no effluent outlet; all water either infiltrates the soil column or evaporates. PS. effluent will be routed to the 300 Area TEDF upon closure of the 300 APT.

\subsection{LIQUID WASTE TRANSFER SYSTEMS}

Through the years, most 300 Area buildings have supported nuclear fuel element fabrication or laboratory research and development related to fuel fabrication. Many of these buildings discharged liquid effluent to the PS. The Retention Process Sewer System (RPS) is connected to the PS and still routinely discharges to the PS. A schematic of basic sewer system operation is presented in Figure 3-1. Table 3-1 identifies the buildings and laboratories connected to the PS.

The PS has always been the only liquid waste transfer system to directly discharge to the 300 APT. In the past, PS effluent contained radioactive and organic and inorganic dangerous waste constituents, some of which remain at detectable levels in TSD unit soils.

Other 300 Area liquid waste transfer systems include the Radioactive Liquid Waste Sewer (RLWS), and the Sanitary Waste System. These systems are not connected to the PS, have never discharged to the trenches, and are not described in the closure plan. 


\subsubsection{The PS}

The PS is a vitreous clay, bell, and spigot collection system serving fifty-five 300 Area facilities. The PS system was originally constructed in 1943 to transfer contaminated 300 Area process liquid waste to the north and south process ponds (Figure 2-4). The section of the sewer that served the north and south process ponds was retired in 1975 and since then, all process sewer effluent has gone to the process trenches (DOE-RL 1992e). This waste contained contaminated cooling water, low-level radioactive waste (primarily uranium), biological and chemical laboratory waste, miscellaneous waste (cleaning agents, solvents), and chemical spills. The PS now discharges only potable and equipment cooling water, steam condensate from building heating, water softener regeneration waste and nonhazardous waste liquids from laboratory drains.

3.2.1.1 Process Sewer Flows. Until 1987, the PS discharged up to 11.7 million liters ( 3 million gallons) per day of maintenance and process effluent. One-third of the daily discharge to the trenches was process cooling and rinse water from fuel fabrication operations. The other two-thirds of the daily influent was from a wide variety of laboratory operations conducted in the 300 Area for the DOE-RL. Effluent flows to the trenches averaged 3,500 liters per minute ( 900 gallons per minute), with peak discharges possibly as high as 7,900 liters per minute $(2,084$ gallons per minute) (DOE-RL 1992d).

Since 1987, the inactivity of fuel fabrication facilities and an aggressive flow minimization program have reduced flows to the current levels: approximately 1,500 liters per minute ( 400 gallons per minute), or approximately 1.9 million liters (500,000 gallons) per day (DOE-RL 1992d). Total annual process sewer flows from 1975 through 1993 are identified in Table 3-2.

\subsubsection{Effluent Content. From 1975 to 1978, the PS operated with few} administrative controls on effluent content. From 1978 until 1987, the Hanford Engineering Development Laboratory (HEDL) managed operation of the PS. In 1978, administrative controls were imposed on discharges of nonradioactive material to the PS by the HEDL Manual, MG-99, Environmental Protection (HEDL 1984). These controls were designed to minimize the impact of PS effluent on the environment and included contaminant concentration restrictions, operating procedures, conspicuous posting, container labeling, and frequent inspections.

From the beginning of operations in 1975 until October 1993, a continuous, composite sampler was located at the headwork and analyzed process sewer effluent for metals, pH, gross alpha, gross beta, and uranium (HEDL 1984; WHC-CM-7-5). HEDL controls required composite samples to be collected weekly. Weekly samples were analyzed for pH, gross alpha, gross beta, metals, and anions. On a monthly basis, weekly samples were composited and screened for known or suspected chemical constituents (except organics) to ensure the attainment of HEDL standards on an annual average basis. These limits restricted releases of cations (i.e., metals), pH, and anions (e.g., sulphates, nitrates), to the standards shown in the manual, which were set to 
MCLs contained in federal DWS. HEDL standards for gross alpha, gross beta, and uranium were set from derived concentration guide (DCG) values provided in DOE orders.

Between 1978 and 1985, routine discharges to the process sewer generally complied with these standards, although it was not unusual for weekly results to indicate parameters (generally only $\mathrm{pH}$ ) in excess of DWS. Effluent $\mathrm{pH}$ generally remained in the 6.5 to 8.5 range with the lowest incidence being 3.0 and the highest being 9.7 (WHC 1990a). Table 3-3 identifies the occasions when the PS exceeded DWS (except for $\mathrm{pH}$ ) at the point of release to the trenches.

After February 1, 1985, the process sewer system and the trenches were completely closed to dangerous waste by administrative controls that required dangerous waste be collected, packaged, and disposed of under dangerous waste management regulations. In March 1985, the HEDL manual was revised to reflect this. This manual was superseded by WHC-CM-7-5, Environmental Compliance, in 1987. This manual further restricted contaminant levels by imposing more stringent administrative control values (ACV)- for sampling parameters to further ensure that MCLS and DCGs were not exceeded in the PS. Since 1985, only three minor instances of concentrations outside regulatory limits has occurred: one involving lead and two involving chloride ions. PS effluent is nondangerous and remains below regulatory limits as reported in the 300 Area Wastewater-Stream Specific Report (WHC 1990a) and the Hanford 300 Area Process Wastewater Characterization Data Report (Stordeur 1992).

Since October 1993, PS effluent sampling has occurred near the 306 Building. This sampling is now performed in accordance with an approved SAP (WHC 1993). Flow is continuously monitored for radionuclides. Grab samples are taken for nonradioactive constituents that now include volatile and semi-volatile organics.

Estimated quantities for all chemicals discharged from 1975 until the implementation of administrative controls in 1985 are listed in Table 3-4. This estimate includes suspected discharges of organic chemicals that were not analyzed for until 1993. Table 3-4 waste inventory estimates are based on investigations performed before 1986 in support of a preliminary 300 APT closure plan (WHC 1988b). These investigations obtained current and historical information from knowledgeable 300 Area operations personnel regarding process waste discharges to the PS. The operations sources were not documented at that time and the information is not reverifiable. However, Table 3-4 information regarding potential process contaminants was used by the CERCLA RI/FS process in performing a comprehensive TSD unit characterization, which is now complete.

The actual discharge quantities were important only in helping to anticipate expected contaminant levels. Other uses of the information (e.g., determining waste distribution within the unit) are no longer appropriate because the 316-5 ERA relocated contaminated sediments within the unit (Chapter 2.0, Section 2.4). Since 1985, essentially the only source of dangerous waste to the trenches has been unplanned releases (Section 3.2.3). 


\subsubsection{Area RPS}

The 300 Area RPS was constructed in 1953 and remains in operation today as a predisposal screening and holding system for potentially radioactive laboratory effluent. Table 3-1 identifies the laboratories connected to the RPS that have a potential to discharge radioactive waste. The RPS was designed to coordinate with the RLWS in serving these laboratories but is also connected to the PS (Figure 3-1).

The RPS effluent is monitored for radioactivity before leaving the building, and if radioactive, is diverted to the RLWS as radioactive waste. If not diverted, RPS effluent continues on a flowpath toward the 307 Retention Basins. Before entering the basins, waste is again monitored for radioactivity. Currently, waste registering greater than 50,000 picocuries per liter beta activity is pumped to the one of two 307 Retention Basins where it is held until the activity is verified by sampling. Effluent verified by sampling as radioactive is disposed of as radioactive liquid waste at the 340 Tank Complex. Waste not registering radioactivity (less than 50,000 picoCuries per liter beta activity) is released to the process sewer system. The RPS currently discharges approximately 189 liters per minute (50 gallons per minute) from the five laboratory facilities to the PS.

The 50,000-picocuries per liter activity level reflects the sensitivity of equipment installed in 1976. Adherence to this level also ensured compliance with DOE orders, requiring the annual average concentration to remain below the maximum permissible concentration (MPC). Use of MPC has since been replaced with the derived concentration guide (DCG) by WHC-CM-7-5. Two RPS monitoring system upgrades are underway (Projects W-345 and W-353) to upgrade the basin monitoring system and in-building diverter stations.

\subsection{WASTE GENERATING PROCESSES}

Fuel fabrication, laboratory research and development, and unplanned releases have been the primary sources of dangerous waste discharged by the PS to the trenches.

\subsubsection{Fuel Fabrication Process Waste}

Fuel fabrication facilities connected to the PS are identified in Table 3-1. From 1975, when the trenches entered service, until 1987 when fuel fabrication essentially ceased, fabrication of fuel elements was primarily for $\mathrm{N}$ Reactor. Fuel fabrication activities routinely used a broad range of organic and inorganic lubricants, solvents, and other chemicals that were discharged to the PS system. The primary discharge from fuel fabrication was cooling and rinse water. These chemicals, along with radionuclides generated by fuel fabrication, are listed in Table 3-5.

$N$ Reactor fuel was fabricated using an extrusion process. This process formed the zirconium cladding and the uranium/silicon fuel core from primary materials and bonded them together in one operation. Lubricants were removed 
using solvents such as trichloroethylene. Temporary copper jackets were removed from fuel elements by dissolution into nitric acid. The uranium core was chemically milled using copper sulfate, nitric acid, and sulfuric acid. Zirconium caps were brazed onto the elements using beryilium (DOE-RL 1988). Fuel elements were steam autoclave tested to detect perforations, and brazed connections were radiographed to detect unbonded areas or uranium in the welds (Young et al. 1991).

Fuel fabrication was a source of approximately 1 percent enriched uranium discharged to the trenches. Fuel fabrication was not typically considered a source of the types of fission products found in the trenches and so fue 1 fabrication facilities were not connected to the RLWS. Radionuclides listed in Table 3-5, other than uranium, originated from the reanodizing of aluminum spacers used in the old reactors before 1975. This waste was normally collected and discharged to the RLWS but occasionally entered the process sewer system (DOE-RL 1992e). Some of these radionuclides were likely deposited in PS sludge and could have been released to the trenches after 1975 during high sewer flows or $\mathrm{pH}$ excursions that no longer occur because of reduced PS flows and process controls.

\subsubsection{Laboratory Process Waste}

The chemical makeup and quantity of 300 Area laboratory waste has not been documented (DOE-RL 1992e). Although a wide variety of laboratory activities are occurring in the 300 Area, laboratory waste is considered to be similar to fuel fabrication process waste because most of the buildings supported fuel fabrication (DOE-RL 1990). Typical laboratory waste could also have consisted of standard laboratory cleaners, reagents, solvents, neutralizers, and drying agents (WHC 1992a). Standard laboratory chemicals primarily used to clean and rinse laboratory equipment are identified in Table 3-3. These could have been discharged directly to the PS through laboratory drains or from the RPS in quantities insignificant to the waste stream.

\subsubsection{Unplanned Waste Releases to the Process Sewer System}

Chemical spills are known to have entered the PS through 300 Area building floor drains. The majority of these releases were of spent uranium-contaminated acid etch solutions. These unplanned releases to the PS since 1975 were documented at the time of the spills. The releases from 1975 to 1986 are summarized in Table 2-3 of the Phase I and II Feasibility Study Report for the 300-FF-1 Operable Unit (DOE-RL 1992e). The documented, unplanned releases to the PS from 1975 to 1980 are identified in unplanned release reports as UPR-300-8 through -29 . Documented unplanned releases from 1980 until the end of fuel fabrication activities in 1986 are identified by date in the same table.

Other unplanned releases to the process sewer system include two spills of perchloroethylene on November 4, 1982 and July 6, 1984 of 455 liters (120 gallons) and 76 liters (20 gallons), respectively. The degradation 
products of perchloroethylene are (trichloroethene, dichloroethene, and vinyl chloride) (Chapter 5.0, Section 5.3.2). All are currently detectable in groundwater except dichloroethene.

Since the completion of characterization sampling in 1991, two releases of ethylene glycol (antifreeze) to the PS have occurred. The first release of 1,364 1iters (360 gallons) was in April 1993 and the second of 7.6 liters (2 gallons) in October. Neither spill was detected in groundwater (Chapter 5.0, Section 5.3.2).

\subsubsection{Other Process Waste}

In the past, some of the facilities listed in Table 3-1 performed activities related to reactor operations, irradiated fuels examinations, chemical separations processes, photographic processing and waste management. Some of the newer facilities support activities such as peaceful uses of plutonium, reactor fuels development, liquid metal technology, environmental remediation technology development and life science programs (WHC 1992e). Although such facilities in the past may have contributed small quantities of radioactive or dangerous waste to the PS, trench soil sampling results reflect that their contribution to the waste stream and to subsequent trench soil contamination is insignificant compared to that of fuel fabrication. Photographic processing and photochemicals are discussed here as the largest documented non-fuel, fabrication-related process.

Since 1975, 300 Area photographic activities have included film badge processing, radiography (including fuel elements) and site photograph processing. Photographic activities still take place in the 3705 Building which was disconnected from the PS in November 1990. Two general categories of photographic chemicals were generated in the 3705 Building, some of which went to the PS before November 1990. These categories are the fixer and hardener solutions, and the stop bath and activator chemicals. The stop bath consisted of acetic acid plus water, and the activator solution consists of potassium hydroxide and potassium sulfite. The fixers and hardener solutions typically include acetic acid, gluconic acid, aluminum sulfate, ammonium thiosulfate, sodium thiosulfate, ammonium acetate, ammonium sulfite, silver, and cadmium. Acids were neutralized before discharge to the PS. Silverbearing solutions were analyzed and processed to remove silver. Photographic solutions containing cadmium at greater than 1 part per million were transported offsite for disposal (Young et al. 1990).

\subsection{CONTAMINATED 300 APT MEDIA}

The 300 APT are leaching trenches that dispose of process sewer effluent by evaporation and infiltration into the soil column. In the past, this effluent contained radioactive and dangerous waste constituents, some of which have remained in trench soils through filtration and adsorption. Current TSD unit soil contamination is characterized in the results of pre- and post-ERA sampling (Appendix 7D) and is discussed in Chapter 4.0. 
Solls beneath the process sewer lines serving the unit were not sampled, but are likely to be similarly contaminated as the result of leaks from sewer piping joints (DOE-RL 1990). TSD unit structures and components were not sampled because of their anticipated demolition and disposal as remediation waste. Remediation of contaminated soils and disposal of unit structures and components are discussed in Chapters 6.0 and 7.0 of this closure plan. 
DOE/RL-93-73, Rev. 0

08/15/94

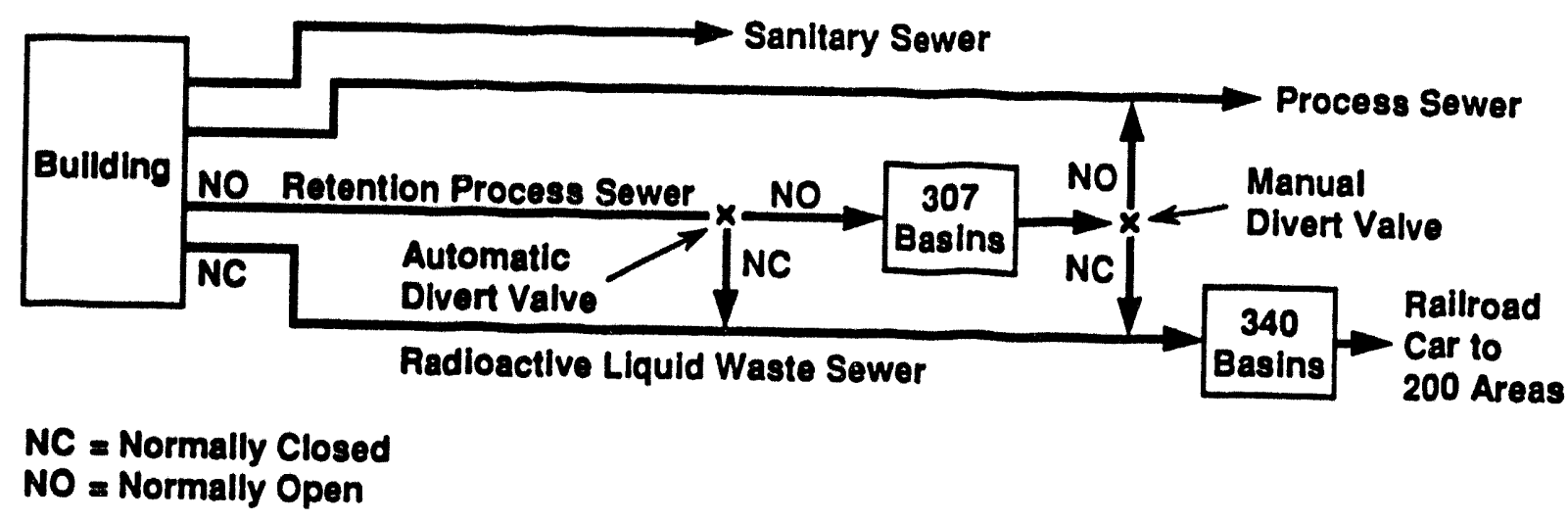

$H 9208024.4$

Figure 3-1. Liquid Waste Transfer Systems Schematic. 
Table 3-1. Index of Facilities Connected to the PS on November 16, 1993. (sheet 1 of 3)

\begin{tabular}{|c|c|c|}
\hline & NUMBER & NAME \\
\hline 1 & $303 \mathrm{~F}$ & Pumphouse (WHC) \\
\hline 2 & $303 \mathrm{~J}$ & Material Storage Building (PNL) \\
\hline 3 & $303 \mathrm{M}$ & Uranium Oxide Facility (WHC) \\
\hline 4 & 304 & Uranium Concretion Facility (WHC) \\
\hline 5 & 305 & Engineering Testing Facility (WHC) \\
\hline 6 & 305B & Hazardous Waste Storage Facility (PNL) \\
\hline 7 & $306 \mathrm{E}$ & Development, Fabrication, and Test Laboratory (WHC) \\
\hline 8 & ${ }^{c} 306 \mathrm{~W}$ & Materials Development Laboratory (PNL) \\
\hline 9 & 308 & Fuels Development Laboratory (via RPS only) (WHC) \\
\hline 10 & 309 & Test Engineering Facility (WHC) \\
\hline 11 & 311 & Tank Farm (WHC) \\
\hline 12 & 313 & N Fuels Manufacturing Support Facility (WHC) \\
\hline 13 & 314 & Engineering Development Laboratory (PNL) \\
\hline 14 & 318 & Radioactive Calibrations Laboratory (PNL) \\
\hline 15 & 320 & Physical Science Laboratory (PNL) \\
\hline 16 & 321 & Hydromechanical/Seismic Facility (WHC) \\
\hline 17 & 323 & Mechanical Properties Laboratory (PNL) \\
\hline 18 & $b, c 324$ & Waste Technology Engineering Laboratory (PNL) \\
\hline 19 & $b, c 325$ & Applied Chemistry Laboratory (via RPS only) (PNL) \\
\hline 20 & $b, c 326$ & Material Science Laboratory (PNL) \\
\hline 21 & $b, c 327$ & Post Irradiation Test Laboratory (PNL) \\
\hline 22 & $b, c 329$ & Chemical Science Laboratory (PNL) \\
\hline 23 & 331 & Life Science Laboratory 1 (PNL) \\
\hline 24 & 3310 & Biomagnetic Lab (PNL) \\
\hline 25 & $331 E$ & Greenhouse (PNL) \\
\hline 26 & $331 \mathrm{~J}$ & Incinerator (PNL) \\
\hline 27 & a333 & N Fuels Fabrication Facility (WHC) \\
\hline
\end{tabular}


Table 3-1. Index of Facilities Connected to the PS

on November 16, 1993. (sheet 2 of 3 )

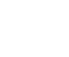

\begin{tabular}{|c|c|c|}
\hline & NUMBER & NAME \\
\hline 28 & 334 & Process Sewer Monitoring Facility (WHC) \\
\hline 29 & 335 & Sodium Testing Facility (WHC) \\
\hline 30 & 336 & High Bay Testing Facility (PNL) \\
\hline 31 & 337 & Technical Management Center (PNL) \\
\hline 32 & 337 & High-bay and Service Wing (WHC) \\
\hline 33 & 338 & Fabrication Shop (KEH) \\
\hline 34 & 340 & Waste Neutralization Facility (WHC) \\
\hline 35 & 382 & Pumphouse (WHC) \\
\hline 36 & 382 & A, B, C Water Storage Tanks (WHC) \\
\hline 37 & 384 & Powerhouse (WHC) \\
\hline$\star \star$ & 3100 & Future Facility (PNL) \\
\hline 38 & 3706 & Communication and Documentation Services (WHC) \\
\hline 39 & $3707 \mathrm{C}$ & Safeguards and Security Maintenance Shop (WHC) \\
\hline 40 & 3708 & Radioanalytical Laboratory (PNL) \\
\hline 41 & 3709 & Paint Shop (WHC) \\
\hline 42 & 3716 & Storage (WHC) \\
\hline 43 & 3717 & Spare Parts Warehouse (WHC) \\
\hline 44 & $3717 \mathrm{~B}$ & Standards Laboratory (WHC) \\
\hline 45 & $3718 \mathrm{~F}$ & Sodium Storage (WHC) \\
\hline 46 & 3720 & Chemistry and Metal Sciences Laboratory (PNL) \\
\hline 47 & 3722 & Construction Shop (KEH) \\
\hline 48 & 3730 & Gamma Irradiation Facility (PNL) \\
\hline 49 & 3732 & old Thoria Lab (WHC) \\
\hline 50 & $3745 A$ & Electron Accelerator Facility (PNL) \\
\hline 51 & $3745 B$ & Positive Ion Accelerator Facility (PNL) \\
\hline 52 & $3746 \mathrm{~A}$ & Radioactive Physics Laboratory (PNL) \\
\hline 53 & $3802 A$ & Steam Pressure Reducing Valve Station (WHC) \\
\hline
\end{tabular}


Table 3-1. Index of Facilities Connected to the PS on November 16, 1993. (sheet 3 of 3 )

\begin{tabular}{|c|c|l|}
\cline { 2 - 3 } \multicolumn{1}{c|}{} & NUMBER & \multicolumn{1}{c|}{ NAME } \\
\hline 54 & $3902 A$ & West Elevated Water Tank \\
\hline 55 & $3902 B$ & East Elevated Water Tank \\
\hline
\end{tabular}

6 Source: WHC 1992d

Notes:

"Fuel Fabrication Facilities.

10 bacilities also connected to the RLWS.

11 'Facilities also connected to the Retention Process Sewer.

$12 \quad W H C=$ Westinghouse Hanford Company

$13 \quad \mathrm{PNL}=$ Pacific Northwest Laboratories 
Table 3-2. Flow History for the PS.

\begin{tabular}{|c|c|c|}
\hline YEAR & $\begin{array}{c}\text { GALLONS } \\
\text { DISCHARGED }\end{array}$ & $\begin{array}{c}\text { GALLONS } \\
\text { PER } \\
\text { MINUTE } \\
\end{array}$ \\
\hline $3 / 16 / 75-12 / 31 / 75$ & $1.8 E+08$ & 431 \\
\hline 1976 & $9.1 E+08$ & 1731 \\
\hline 1977 & $5.0 E+08$ & 951 \\
\hline 1978 & $5.0 E+08$ & 951 \\
\hline 1979 & $1.2 E+09$ & 2283 \\
\hline 1980 & $8.4 E+08$ & 1600 \\
\hline 1981 & $8.5 E+08$ & 1620 \\
\hline 1982 & $8.5 E+08$ & 1620 \\
\hline 1983 & $9.1 E+08$ & 1731 \\
\hline 1984 & $9.3 E+08$ & 1770 \\
\hline 1985 & $9.4 E+08$ & 1790 \\
\hline 1986 & $9.0 E+08$ & 1712 \\
\hline 1987 & $8.6 E+08$ & 1636 \\
\hline 1988 & $4.3 E+08$ & 818 \\
\hline 1989 & $5.0 E+08$ & 951 \\
\hline 1990 & $5.2 E+08$ & 990 \\
\hline 1991 & $3.4 E+08$ & 647 \\
\hline 1992 & $1.5 E+08$ & 285 \\
\hline 1993 & $1.1 E+08$ & 215 \\
\hline
\end{tabular}

Note: The 300 Area process sewer trenches were placed in operation on March 16, 1975. 
Table 3-3. Occasions When the PS Exceeded Drinking Water Standards at the Point of Release to the Environment.

(excluding $\mathrm{pH}$ )

5

6

7

8

9

10

11

12

13

14

15

\begin{tabular}{|c|c|c|c|}
\hline Date & Parameter & $\begin{array}{c}\text { DWS Limit } \\
(\mathrm{ppb})\end{array}$ & $\begin{array}{c}\text { Result } \\
(\mathrm{ppb})\end{array}$ \\
\hline $05 / 10 / 76$ & $\mathrm{Hg}$ & 2 & 8.4 \\
\hline $05 / 17 / 76$ & $\mathrm{Cd}$ & 10 & $<20$ \\
\hline $12 / 14 / 77$ & $\mathrm{Cd}$ & 10 & 34 \\
\hline $04 / 25 / 78$ & $\mathrm{Cu}$ & 1000 & 4000 \\
\hline $04 / 25 / 78$ & $\mathrm{Cr}$ & 50 & 150 \\
\hline $04 / 25 / 78$ & $\mathrm{NO}$ & 45 & 69 \\
\hline $09 / 05 / 78$ & $\mathrm{Cu}$ & 1000 & 1200 \\
\hline $05 / 08 / 79$ & $\mathrm{Cr}$ & 50 & $44-63$ \\
\hline $02 / 03 / 81$ & $\mathrm{Hg}$ & 2 & 3.7 \\
\hline $02 / 24 / 82$ & $\mathrm{Hg}$ & 2 & 2.2 \\
\hline $02 / 24 / 82$ & $\mathrm{Cd}$ & 10 & 19 \\
\hline $06 / 03 / 86$ & $\mathrm{Cl}$ & 250,000 & 322,000 \\
\hline $08 / 12 / 86$ & $\mathrm{~Pb}$ & 50 & 250 \\
\hline $01 / 05 / 88$ & $\mathrm{Cl}$ & 250,000 & 417,000 \\
\hline $05 / 25 / 88$ & $\mathrm{~Pb}$ & 50 & 150 \\
\hline
\end{tabular}

21

22

Source: WHC 1988b. 
Table 3-4. Estimated Nonradiological Chemical Waste Inventory for the Process Trenches

\begin{tabular}{|c|c|c|c|c|}
\hline \multicolumn{2}{|c|}{$\begin{array}{c}\text { Total of Intermittent Discharges } \\
\text { of Dangerous Chemicals Ending } \\
\text { February } 1,1985^{e, k}\end{array}$} & \multicolumn{3}{|c|}{$\begin{array}{l}\text { Larger Discharges }{ }^{\circ} \text { Continuing } \\
\text { Until September } 1986^{\circ}\end{array}$} \\
\hline$<g$ & $<k g$ & & & $\begin{array}{l}\text { Total of } \\
\text { Larger } \\
\text { Discharges }\end{array}$ \\
\hline $\begin{array}{l}\text { Ammonium biofluoride } \\
\text { Antimony } \\
\text { Arsenic } \\
\text { Barium } \\
\text { Cadium } \\
\text { Dioxing } \\
\text { Dioxing } \\
\text { Hydrocyanic acid } \\
\text { Pyridine } \\
\text { selenium and compounds } \\
\text { Thiourea } \\
\text { Miscellaneous } \\
\text { laboratory chemicals }\end{array}$ & $\begin{array}{l}\text { Benzene } \\
\text { Carbon tetrachloride } \\
\text { Chromium } \\
\text { chlorinated benzenes } \\
\text { Degreasing solvents } \\
\text { Formaldehyde } \\
\text { Formic acid } \\
\text { Hexachlorophene } \\
\text { Kerosene } \\
\text { Lead } \\
\text { Methyl ethyl ketone } \\
\text { Mercury } \\
\text { Naphthal ene } \\
\text { Nickel } \\
\text { Phenol } \\
\text { silver } \\
\text { Sulfuric acid } \\
\text { Tetrachloroethylene } \\
\text { Toluene } \\
\text { Tributylphosphate } \\
\text { (paraffin } \\
\text { hydrocarbon } \\
\text { solvents } \\
1,1,1-t r i c h l o r o e t h a n e \\
\text { Trichloroethylene } \\
\text { xylenes }\end{array}$ & $\begin{array}{l}\text { Copper } \\
\text { Detergents } \\
\text { Ethylene } \\
\text { glycol } \\
\text { Heating oil } \\
\text { Hydrofluoric } \\
\text { acid } \\
\text { Nitrates } \\
\text { Nitric acid } \\
\text { Paint solvents } \\
\text { Tetrachloroethylene } \\
\text { Photo chemicals } \\
\text { Sodium chloride } \\
\text { Sodium hydroxide } \\
\text { Uranium }\end{array}$ & 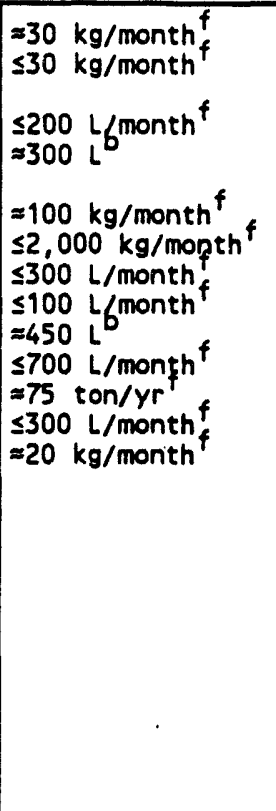 & $\begin{array}{l}3,960 \mathrm{~kg} \\
3,460 \mathrm{~kg} \\
26,400 \mathrm{~L} \\
300 \mathrm{~L} \\
13,200 \mathrm{~kg} \\
264,000 \mathrm{~kg} \\
39,600 \mathrm{~L} \\
13,200 \mathrm{~L} \\
450 \mathrm{~L} \\
92,400 \mathrm{~L} \\
825 \mathrm{ton} / \mathrm{hr} \\
39,600 \mathrm{~L} \\
2,640 \mathrm{~kg}\end{array}$ \\
\hline
\end{tabular}

Source: Adapted from DOE-RL 1992a.

$1 \mathrm{~kg}=2.2 \mathrm{lbs}$.

$1 L=0.26 \mathrm{gal}$.

aThese discharges, except for the spills, were relatively continuous. bnown spills.

"Included only because of the potential for dioxin to exist as trace impurity in chlorinated benzenes.

dSeptember 1986 is approximate end of fuel fabrication activities.

'February 1, 1985 is date of administrative controls disallowing discharge of dangerous waste to the PS.

fMonthly or annual quantity is an average over a 17 -month period beginning February 1985 and ending September 1986.

${ }^{9}$ Individual photographic chemicals are listed in Section 3.3.4.

hal so perchlorethylene, tetrachlorethene.

ialso trichlorethylene, trichlorethene.

'Total is monthly average discharge $x$ i2 (month per year) $x 11$ (operating years from 1975 to 1986).

${ }^{\prime}$ Includes organics that were not analyzed for by PS effluent sampling. 
Table 3-5. Fuel Fabrication Chemicals and Radionuclides.

\begin{tabular}{|c|c|}
\hline $\begin{array}{c}\text { Chemicals routinely used in fuel } \\
\text { fabrication }\end{array}$ & $\begin{array}{c}\text { Radionuclides generated by fuel } \\
\text { fabrication }\end{array}$ \\
\hline Chromic acid & Scandium- 46 \\
\hline Chromium trioxide & Chromium-51 \\
\hline Copper sulfate & Cobalt-58 \\
\hline Hydrofluoric acid & Iron-59 \\
\hline Nitric acid & Cobalt-60 \\
\hline Oxalic acid & Zinc- 65 \\
\hline Phosphoric acid & Zirconium/niobium isotopes \\
\hline Potassium nitrite & Cesium-137 \\
\hline Sodium aluminate & Promethium-147 \\
\hline Sodium bisulfate & Thorium-234 \\
\hline Sodium carbonate & Uranium isotopes \\
\hline Sodium dichromate & Plutonium isotopes \\
\hline Sodium fluorosilicate & \\
\hline Sodium gluconate & \\
\hline Sodium hydroxide & \\
\hline Sodium nitrate & \\
\hline Sodium nitrite & \\
\hline Sodium pyrophosphate & \\
\hline Sodium silicate & \\
\hline Sulfuric acid & \\
\hline Trichloroethylene & \\
\hline
\end{tabular}




\section{CONTENTS}

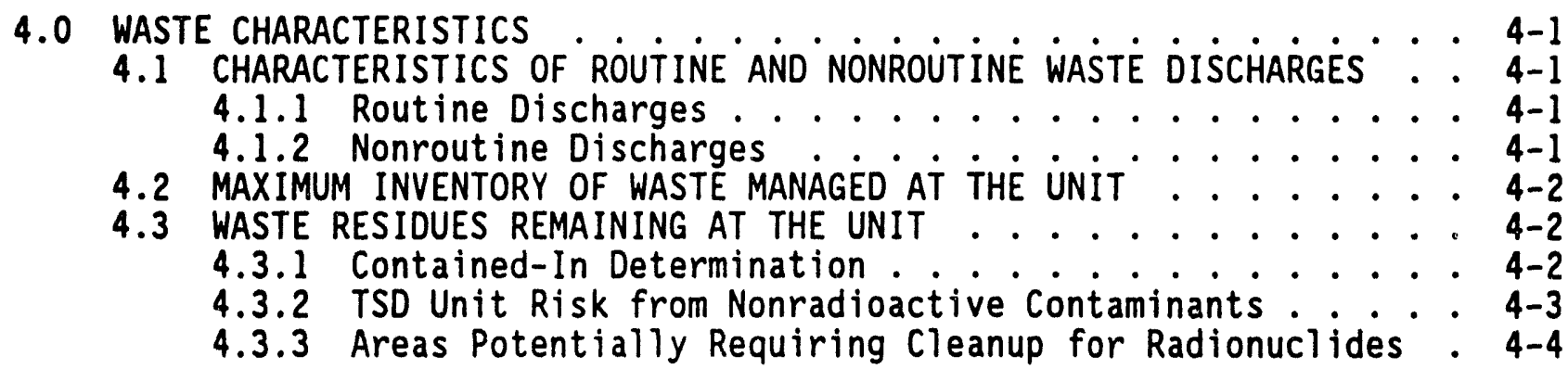

\section{TABLES}

4-1. Nonradioactive Soil Contaminants of Potential Concern in 300 APT Soil ................ . . 4-1

4-2. Nonroutine Discharges Designation Resuits . . . . . 4-2

4-3. Sampling Results for Selected Radioactive Contaminants

in the Process Trenches . . . . . . . . . . . . . . 4-3

4-4. Radionuclide Dose-Based Concentrations . . . . . . . . 4-4 
This page intentionally left blank. 


\subsection{WASTE CHARACTERISTICS}

This chapter discusses the inventory and characteristics of the waste disposed of at the 300 APT. It also discusses the nature and extent of the contamination remaining at the unit. Information regarding radioactive contaminants at the TSD unit is inciuded in this closure plan; however, radionuclides are not considered RCRA dangerous waste and information regarding them is presented for information only.

\subsection{CHARACTERISTICS OF ROUTINE AND NONROUTINE WASTE DISCHARGES}

This section discusses the waste characteristics of the routine and nonroutine discharges to the 300 APT TSD.

\subsubsection{Routine Discharges}

The chemicals routinely discharged to the process sewer by fuel fabrication facilities have been identified in Table 3-5. The chemical makeup and quantities of routine laboratory discharges are not documented. However, laboratory waste is expected to have been standard laboratory agents (Chapter 3.0, Section 3.3.2), and waste similar to fuel fabrication process waste (Chapter 3.0, Section 3.3.1), al though in smaller quantities (DOE-RL 1990).

Sampling analyses of routine discharges indicates that in the past the trenches occasionally received effluent that exceeded DWS. Table 3-3 summarizes parameters that exceeded DWS from 1978 to 1988. None of these DWS exceedances were significant enough to designate the effluent as dangerous waste under the concentration-based criteria for characteristic waste (WAC 173-303-90) or for state-only criteria waste (WAC 173-303-100). However, Table 3-4 identifies spent solvents that would designate the PS effluent stream as F-listed (i.e., F002, F003, F005) waste (WAC 173-303-9904) under the EPA waste mixture rule [40 CFR 261.3 (b)(2)]. Section 4.3 discusses the transfer of listed waste codes to TSD unit soils.

38

39

40

41

42

43

44

\subsubsection{Nonroutine Discharges}

The nonroutine discharges to the TSD consisted of unplanned releases (spills) to floor drains in facilities connected to the PS. The chemical content of documented, unplanned releases to the process sewer from 1975 to 1986 is documented in Table 2-3 of Phase I and II Feasibility Study Report for the 300-FF-1 Operable Unit (DOE-RL 1992e). These spills were primarily acid etch solutions from the fuels fabrication process.

The most significant of these spills underwent after-the-fact waste designation in 1986 based on spill report information. The nature and concentration of the waste caused the discharges to designate as F001-listed (spent solvents) waste, D002 (corrosive characteristic) waste, D007 (toxicity 
characteristic; chromium), and state-only criteria (WTO2) waste. The results of this designation exercise are shown in Table 4-1.

It is unlikely that the characteristic or criteria waste designations would have been retained in the effluent by the time it arrived at the unit because of constituent dilution with copious amounts of clean, neutralizing cooling water in the PS and in the trenches. The results of routine sampling did not reflect DWS exceedances of weekly sampling parameters or of monthly screening parameters immediately after the spills. However, the PS effluent arriving at the unit would still retain the F001 listing under the EPA waste mixture rule.

\subsection{MAXIMUM INVENTORY OF WASTE MANAGED AT THE UNIT}

The estimated quantities of chemicals discharged to the 300 APT from 1975 until the implementation of administrative controls in 1985, are shown in Table 3-4. However, the total amount of dangerous waste discharged to the unit is indeterminate. The process sewer flows shown in Table 3-2 can be used in calculating the total volume of waste water sent to the unit from 1975 through 1993, as approximately 49.6 billion liters ( 12.4 billion gallons). The relative volume and concentrations of dangerous waste constituents in the PS effluent stream were very small. Consequently, this figure does not represent a volume of dangerous waste.

\subsection{WASTE RESIDUES REMAINING AT THE UNIT}

This section addresses residual contamination in TSD unit soils. It discusses removal of dangerous waste codes from these soils, characterizes unit risk from nonradioactive contaminants, and identifies the potential extent of cleanup required for radionuclides.

\subsubsection{Contained-In Determination}

Upon discharge of listed PS effluent to the TSD unit soil column, the soil gained the F-listing under the contained-in policy of WAC-173-303-070(2)(a). However, resiclues of listed waste remaining in environmental media (e.g., soils) may have this listing withdrawn if their concentration falls below health-based residential standards calculated using MTCA Method B formulas (Eaton 1993). The organic chemicals that caused the effluent entering the ponds to be listed do not exceed these limits in soils. Consequently, a contained-in determination from Ecology will be sought, which will remove the F-listing from unit soils. As discussed in Chapter 7.0, Section 7.5.3, removal of this listing could ease disposal restrictions on TSD unit waste soils. 


\subsubsection{TSD Unit Risk from Nonradioactive Contaminants}

The TSD unit soil sampling was performed by the 300-FF-1 oU immediately before and after the TSD unit excavations in support of the 316-5 Process Trenches ERA (Chapter 2.0, Section 2.4). Soil samples were analyzed for radionuclides, volatile organics, semivolatile organic compounds, polychlorinated biphenyls (PCB), and metals. These sampling results were used to determine the effectiveness of the ERA. They were also used by the 300-FF-1 OU RI/FS to characterize unit risk in assessing the need for further RA at the unit. The risk assessment was performed using HSBRAM methodology. The risk assessment process provides a high degree of confidence that eliminated constituents pose only insignificant risk to human health and the environment (DOE-RL 1994).

The ERA redistributed contamination at the TSD unit, creating essentially two separate areas; the contaminated spoils area and relatively clean remaining trench areas. The risk assessment addressed these areas separately. Pre-ERA sampling results were used to represent the spoils area and post-ERA results were used to represent the remaining trench area.

Table 4-2 identifies the list of nonradioactive contaminants of potential concern at the TSO unit. This list was formulated before the risk assessment was performed by comparing ERA sample results to background (DOE-RL 1992b) or residential HBLs as preliminary screening criteria (DOE-RL 1992d).

The risk assessment recognized future land use as industrial. Under this usage assumption, the primary exposure was identified as being to onsite industrial workers or offsite residential or recreational receptors (DOE-RL 1992d). The risk assessment process numerically quantifies toxic or carcinogenic effects to humans as health quotient or lifetime incremental cancer risk (ICR), respectively (DOE-RL 1992d). Table 6-21 of the Phase I RI (DOE-RL 1992d) eliminates from further consideration all constituents with an ICR below $1 E-6$ or a hazard quotient below 1.0. Total pathway risk greater than 1E-5 required further consideration (DOE-RL 1994).

Of the Table 4-2 contaminants of potential concern, only arsenic, beryllium, chromium, copper, benzo(a)pyrene, chrysene, and PCBs in the spoils area exceeded the risk levels under industrial exposure scenario. Copper was retained as a contaminant of concern to surface water via groundwater. Under this exposure assumption, the nonradioactive contaminants at the post-ERA trenches provide total ICR of $3 E-6$ ICR requiring no further consideration. However, the contaminants in the spoils area provide total ICR of 5E-5, requiring further consideration.

Table 2-2 of the Phase III FS (DOE-RL 1994) further reduces this list by eliminating arsenic, beryllium, chromium, and copper as contaminants of concern. Arsenic and beryllium were deleted as not actually exceeding sitewide background. Beryllium also had a limited number of detections. Chromium was deleted as actually being the much less toxic trivalent chrome and not hexavalent chromium (DOE-RL 1994). Copper was deleted as a potential groundwater contaminant because low groundwater concentrations indicated no threat to surface water quality standards. 
This leaves only benzo(a)pyrene, chrysene, and PCBs as nonradioactive contaminants of concern to the TSD unit as identified by the CERCLA RI/FS process. These organic contaminants exist only at the spoils area of the TSD unit and at concentrations below MTCA Method $C$ industrial cleanup levels. This is the contaminant level under which the TSD unit can undergo modified closure. Table 4-7 of the Phase III FS (DOE-RL 1994) has assigned OU soils a PRG for these organics that TSD unit levels do not exceed. Consequently, the OU is not driven to remediate the TSD for any nonradioactive contaminants to protect onsite industrial workers or offsite residential or recreational receptors. Further, the RCRA unit is not driven to remediate soils to meet MTCA Method C industrial cleanup levels in order to qualify the site for modified closure. However, remediation of TSD unit soils would be required to qualify the site for RCRA clean closure.

\subsubsection{Areas Potentially Requiring Cleanup for Radionuclides}

Under the industrial usage scenario, the RI/FS process has identified no risk from TSD unit dangerous waste contaminants that would require cleanup of the trenches. However, radionuclides are much more prevalent and exist at higher concentrations than nonradiological contaminants. Radionuclides are not considered RCRA dangerous waste but are within the scope of CERCLA regulations, and will likely drive the CERCLA unit to clean up portions of the TSD.

Cleanup of radionuclides can most simply be implemented through the identification of indicator contaminants whose remediation will al so indicate that cleanup for other radionuclides has been met. The indicator contaminants for the TSD unit are ${ }^{60} \mathrm{Co}$ and ${ }^{238} \mathrm{U}$. The indicator contaminant for the impoundment area is ${ }^{238} U$ and the indicator contaminant for the remainder of the trenches is ${ }^{60} \mathrm{Co}$ (DOE-RL 1994). Cleanup of the more prevalent and concentrated radioactive contaminants will also reduce dangerous waste contaminant levels (DOE-RL 1994). Because this remediation will affect selection of a RCRA closure option. TSD unit closure will not be finalized until completion of the CERCLA cleanup.

Soil sampling results for the indicator contaminants are shown in Table 4-3. The allowable concentration for alternative annual exposure (dose) limits is presented in Table 4-4. One of these annual dose limits could be selected by the ROD. A comparison of Table 4-3 sampling results with Table 4-4 allowable concentrations for each exposure limit gives an idea of the extent of cleanup necessary for each exposure alternative.

The results of such a comparison can be summarized as follows. Much of the spoils area exceeds the allowable concentration for ${ }^{238} U$ at the highest alternative exposure of 25 millirems per year. This condition could require total cleanup of spoils areas. The remainder of the trenches do not exceed allowable concentrations for ${ }^{60} \mathrm{Co}$ even at the most restrictive exposure of 3 millirems per year. This means that these areas initially may not be slated for cleanup. However, field screening during excavations and after removal of structures and piping could identify greater cleanup needs.

52

940810.1342 
The TSD unit piping, structures, and components were not considered in the risk assessment. These will be demolished and the waste removed under all closure scenarios to gain access to potentially contaminated unit soils. 
This page intentionally left blank. 
(.) Table 4-1. Nonroutine Discharges Designation Results. (sheet 1 of 2)

\begin{tabular}{|c|c|c|c|}
\hline Date & Description & Quantity & signation \\
\hline $06 / 75$ & $\begin{array}{l}\text { Waste etch acids containing } \mathrm{HF} \text {, } \\
\mathrm{HNO}_{3}, \mathrm{H}_{2} \mathrm{SO}_{4} \text {, chromic acid with } \\
\mathrm{Cu}, \mathrm{U} \text { and } 2 r \text { in solution }\end{array}$ & Unknown & $\begin{array}{l}\text { D002 } \\
\text { WT02 } \\
\text { D007 (DW) }\end{array}$ \\
\hline $07 / 03 / 76$ & $\begin{array}{l}\mathrm{HNO}_{3} \text { solution containing } \\
121.5 \mathrm{~kg} \text { of depleted } U\end{array}$ & $847 \mathrm{Gal}$. & $\begin{array}{l}\text { D002 } \\
\text { WT02 }\end{array}$ \\
\hline $06 / 02 / 78$ & $\begin{array}{l}\text { Solution primarily made up of } \\
\text { water with some waste etch } \\
\text { acids ( } \mathrm{HF}, \mathrm{HNO}_{3}, \mathrm{H}_{2} \mathrm{SO}_{4}, \mathrm{~W} / \mathrm{Cu} \text {, } \\
U \text { and } \mathrm{Zr} \text { in solution) }\end{array}$ & $18,780 \mathrm{Gal}$ & $\begin{array}{l}\text { D002 } \\
\text { WT02 }\end{array}$ \\
\hline $10 / 30 / 79$ & $\begin{array}{l}\text { Uranium bearing acid waste } \\
\text { containing } \mathrm{HNO}_{3} \text { and } \mathrm{H}_{2} \mathrm{SO}_{4} \text { with } \\
\text { Uranium in solution }\end{array}$ & Unknown & $\begin{array}{l}\text { D002 } \\
\text { WT02 }\end{array}$ \\
\hline $01 / 12 / 80$ & 50 percent $\mathrm{NaOH}$ solution & $<.116 \mathrm{NaOH}$ & $\begin{array}{l}\text { D002 } \\
\text { WT02 }\end{array}$ \\
\hline $02 / 15 / 80$ & $\begin{array}{l}\text { Waste etch acids containing } \\
\mathrm{HNO}_{3} \text { and } \mathrm{H}_{2} \mathrm{SO} \text { with Uranium } \\
\text { in solution }\end{array}$ & $\begin{array}{l}\text { Sma1l quantity } \\
\text { exact volume } \\
\text { unknown }\end{array}$ & $\begin{array}{l}\text { D002 } \\
\text { WT02 }\end{array}$ \\
\hline $\begin{array}{l}07 / 21 / 80 \\
07 / 28 / 80\end{array}$ & $\begin{array}{l}\text { Waste etch acids containing } \\
\mathrm{HNO}_{3} \text { and } \mathrm{HF}\end{array}$ & $\begin{array}{l}\text { Small quantity } \\
\text { exact volume } \\
\text { unknown }\end{array}$ & $\begin{array}{l}\text { DO02 } \\
\text { WT02 }\end{array}$ \\
\hline $08 / 05 / 80$ & Nitric Acid & $\begin{array}{c}\text { Small quantity } \\
\text { exact volume } \\
\text { unknown }\end{array}$ & $\begin{array}{l}\text { D002 } \\
\text { WT02 }\end{array}$ \\
\hline $08 / 19 / 80$ & $\begin{array}{l}\text { Uranium bearing acid - } \mathrm{HNO}_{3} \\
\text { and } \mathrm{H}_{2} 8 \mathrm{BO}_{4}\end{array}$ & Unknown & $\begin{array}{l}\text { DOO2 } \\
\text { WTO2 }\end{array}$ \\
\hline 08/80 & $\begin{array}{l}\text { Etch acid consisting of } \mathrm{HNO}_{3} \\
\text { and } \mathrm{H}_{2} \mathrm{SO}_{4}\end{array}$ & $\begin{array}{l}\text { Small quantity } \\
\text { exact volume } \\
\text { unknown }\end{array}$ & $\begin{array}{l}\text { Do02 } \\
\text { WT02 }\end{array}$ \\
\hline 08/80 & $\begin{array}{l}\text { Waste etch acids containing } \\
\text { nitric and hydrofluoric acid }\end{array}$ & $\begin{array}{l}\text { Small quantity } \\
\text { exact volume } \\
\text { unknown }\end{array}$ & $\begin{array}{l}\text { Do02 } \\
\text { WTO2 }\end{array}$ \\
\hline $09 / 22 / 80$ & 50 percent $\mathrm{NaOH}$ solution & $290 \mathrm{Gal}$ & $\begin{array}{l}\text { D002 } \\
\text { WT02 }\end{array}$ \\
\hline
\end{tabular}


1 Table 4-1. Nonroutine Discharges Designation Results. (sheet 2 of 2)

\section{Date}

$09 / 30 / 80$

$11 / 04 / 82$

$07 / 06 / 84$

$02 / 01 / 86$

\section{Description}

Nitric, sulfuric, and chromic acid, followed by $\mathrm{NH}_{4} \mathrm{~F}_{2}$ and $\mathrm{NaOH}$

Perchloroethylene, spent

Perchloroethylene, spent

Waste etch acids containing $\mathrm{HF}$ and $\mathrm{HNO}_{3}$ with $\mathrm{Zr}, \mathrm{Cr}$, Uranium and $\mathrm{Cu}$ in solution

\section{Quantity Designation}

Unknown

D002

WT02

Approximately F001 $120 \mathrm{Ga} 1$.

Approximately F001 $20 \mathrm{Gal}$.

$350 \mathrm{Gal}$.

D002

WTO2

D007 (DW) 
Table 4-2. Nonradioactive Soil Contaminants of Potential Concern in 300 APT Soil.'

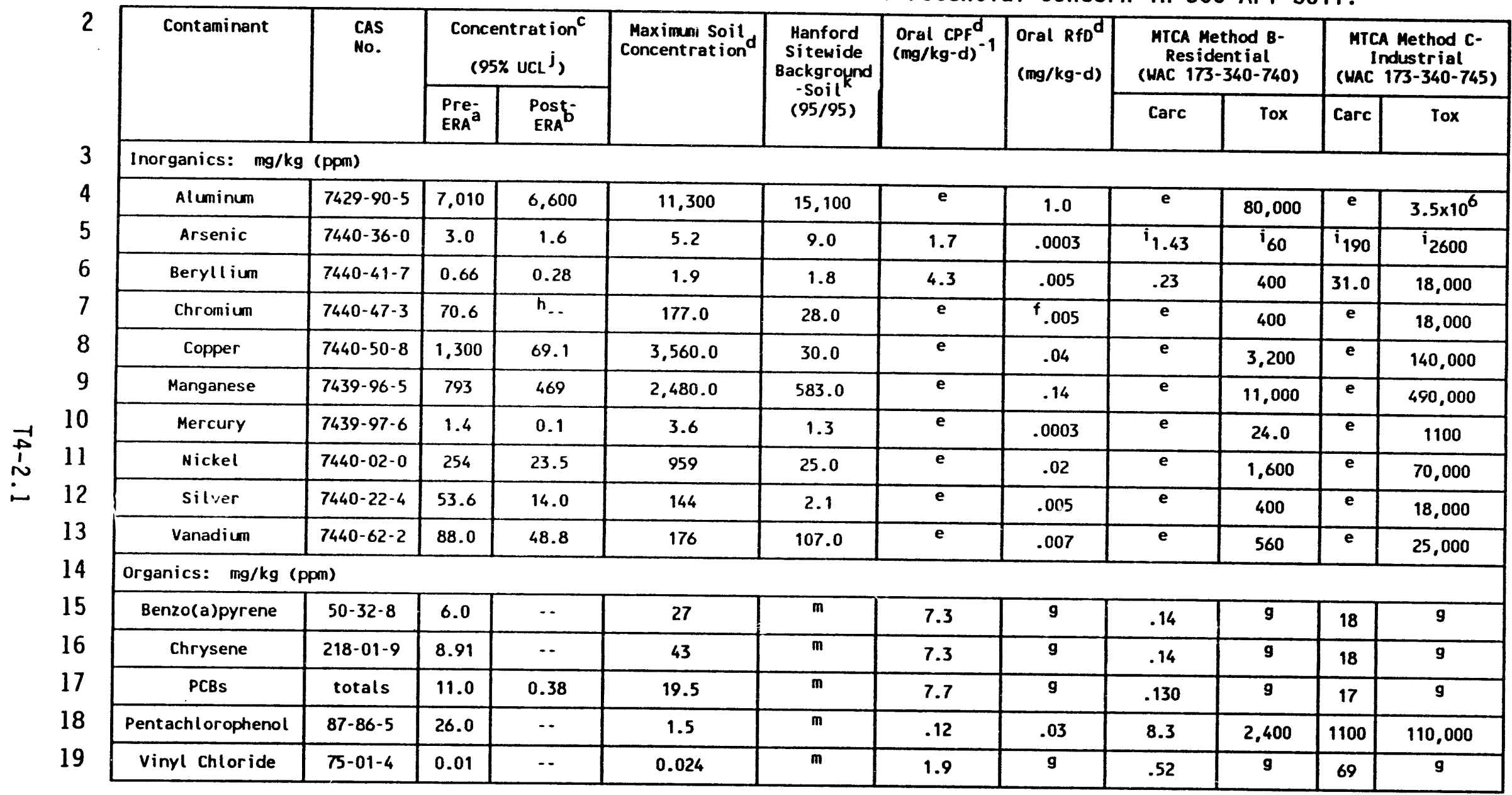


CAS = Chemical Abstract System

MTCA $=$ Model Toxics Control Act

$U C L=$ Upper confidence limit

$\mathrm{CPF}=$ Cancer potency factor [same as slope factor (SF)]

RfD = Chronic reference dose

a Concentration representative of the ERA impoundment area and the north end of each trench.

b Concentration representative of trench areas other than the ERA impounchent and the north end of each trench.

c Source: DOE-RL 1992d, Table 6-1.

d Source: DOE-RL 1992d, Table 4-15.

-Current with first guarter 1994 integrated Risk Information System (IRIS, EPA 1991).

- Chrysene value based on benzo(a)pyrene used as a surrogate based on structural-activity relationships.

-Manganese value is for oral ingestion of soil via food. CLARC II uses RfD for oral soil ingestion via drinking water.

e Not classified as a carcinogen or not carcinogenic via this exposure route (DOE-RL 1992a).

value is for hexavalent chrome.

g Toxicity factor not available from EPA [i.e.. IRIS, Heal th Effects Sumary Table (HEAST), STSC].

-- = Not detected.

Gastrointestinal absorption factor (AB1) of .4 used (instead of 1.0) in MTCA calculations for arsenic (Ecology 1994b).

$95 \%$ UCL for the mean soil concentration (DOE-RL 1992d).

Hanford Site Background (DOE-RL 1992b).

Source: DOE-RL 1992d, Table 4-31.

Hanford Site Background not established for these organic chemicals.

-1
$\vdots$
$\sim$ 
Table 4-3. Sampling Results for Selected Radioactive Contaminants in the Process Trenches.

\begin{tabular}{|c|c|c|c|c|c|c|c|c|c|c|c|}
\hline Locntion & Deptil & $\begin{array}{c}\text { Cesiini!I } \\
137 \\
\mathrm{pCi} / \mathrm{g}\end{array}$ & $\begin{array}{c}\text { Coball } \\
\text { 611 } \\
\text { pCi/g }\end{array}$ & $\begin{array}{c}\text { Radium!' } \\
226 \\
\text { pCi/g }\end{array}$ & $\begin{array}{c}\text { Thorimin } \\
228 \\
\mathrm{pCi} / \mathrm{g}\end{array}$ & $\begin{array}{c}\text { Umaliumin } \\
234 \\
\mathrm{pCi} / \mathrm{g}\end{array}$ & $\begin{array}{c}\text { Uranimin } \\
235 \\
\mathrm{pCi} / \mathrm{g}\end{array}$ & $\begin{array}{c}\text { Uranimin' } \\
235 \mathrm{G} \\
\mathrm{pCi} / \mathrm{g}\end{array}$ & $\begin{array}{l}\text { Uranium!' } \\
238 \\
\text { pCigg }\end{array}$ & $\begin{array}{c}\text { Uranimu!n } \\
238 \mathrm{G} \\
\mathrm{pC} \mathrm{i} / \mathrm{g}\end{array}$ & $\begin{array}{c}\text { Zime } \\
6.5 \\
p C i / g\end{array}$ \\
\hline $316-5$ VPT-1 & 0.5 & 1.21 & 0.14 & 0.32 & 0.41 & 60 & 3.93 & $\mathrm{NA}$ & 41 & $\mathrm{NA}$ & NA \\
\hline 316-5 VIT-1 & 1.5 & 0.91 & ND & 0.37 & 0.48 & 45 & 6.1 & NA & 32 & NA & NA \\
\hline 316-5 VPT-1 & 4.3 & 1.47 & ND & 0.36 & 0.69 & 59 & 7.73 & NA & 4 & NA & NA \\
\hline 316-5 VPT-1 & 6.5 & ND & ND & 1.57 & 0.83 & 17 & 2.05 & NA & 12 & NA & $\mathrm{NA}$ \\
\hline 316-5 VPT-1 & 11 & ND & ND & 0.37 & ND & 16 & 2.16 & NA & 11 & NA & NA \\
\hline 316-SE POST & 0.5 & ND & ND & 0.27 & 0.35 & 8.45 & 1.11 & NA & 5.98 & $\mathrm{NA}$ & NA \\
\hline 316-5E POST & 0.5 & 0.04 & ND & 0.24 & 0.33 & 3.50 & 0.37 & NA & 2.49 & NA & NA \\
\hline 316-SE POST & 0.5 & 0.24 & 0.05 & 0.35 & 0.44 & 7.15 & 1.0 & NA & 5.35 & NA & NA \\
\hline 316-SE POST & 0.5 & 0.70 & 0.32 & 0.26 & 0.37 & 6.20 & 0.90 & NA & 4.71 & NA & NA \\
\hline 316-SE PRE & 0.5 & NA & $\mathrm{NA}$ & ND & $N A$ & 72 & 7.9 & NA & 64 & NA & NA \\
\hline 316.SE PRE & 0.5 & 0.61 & 0.14 & 0.40 & 0.81 & 106 & 10 & NA & 77 & NA & NA \\
\hline 316-SE PRE & 0.5 & 0.89 & 0.79 & 0.99 & 16 & 8,790 & 1,556 & 638 & 6,032 & 9,143 & NA \\
\hline 316-5E PRE & 0.5 & 1.07 & 1.03 & 0.56 & 0.71 & 72 & 4.2 & NA & 69 & $N A$ & NA \\
\hline 316-5E PRE & 0.5 & 1.08 & 0.55 & 1.24 & 5.39 & 3,565 & 319 & NA & 2.917 & NA & NA \\
\hline 316-5E PRE & 0.5 & 1.14 & 0.96 & 0.97 & 16.79 & 9,747 & 379 & NA & 9,132 & NA & NA \\
\hline 316-SE PRE & 3 & 0.34 & 0.07 & 0.38 & 0.66 & 43 & 7.39 & NA & 33 & NA & NA \\
\hline 316-SE PRE & 3 & 0.34 & 0.05 & 0.43 & 0.52 & 5.54 & 0.68 & NA & +.29 & NA & NA \\
\hline 316-SE PRE & 3 & 0.53 & 0.36 & 0.40 & ND & 1,492 & 138 & 85 & 1,072 & 1,246 & $\mathrm{NA}$ \\
\hline 3!G-5E PRE & 3 & 0.35 & 0.11 & 0.49 & 1.53 & 503 & 74 & NA & 357 & NA & NA \\
\hline 316-SE PRE & 5 & 0.04 & 0.08 & 0.39 & 0.56 & 13 & 2.13 & NA & 8.64 & NA & NA \\
\hline 316-SE PRE & 5 & 0.39 & 0.08 & 0.39 & 0.57 & 68 & 9.19 & NA & so & NA & NA \\
\hline 316-5E PRE & 5 & 0.52 & 0.22 & 0.42 & 0.64 & 12 & 1.72 & NA & 9.19 & NA & $\mathrm{NA}$ \\
\hline 316-5E PRE & 5 & 0.69 & 0.03 & 0.42 & 0.62 & 37 & 2.94 & NA & 30 & NA & NA \\
\hline 316-5W PRE & 0.5 & 0.60 & 0.72 & 1.13 & 1.47 & 257 & -12 & NA & 283 & NA & NA \\
\hline 316-5W PRE & 0.5 & 1.32 & 1.78 & 0.84 & 1.24 & 1,515 & 100 & NA & 1,062 & NA & NA \\
\hline 316-SW PRE & 0.5 & 1.73 & 1.57 & 1.24 & 2.59 & 2,602 & 216 & NA & 1,779 & NA & NA \\
\hline 316-SW PRE & 0.5 & 2.29 & 2.51 & 1,610 & 2.72 & 390 & 19 & NA & 290 & NA & ND \\
\hline 316-5W PRE & 3 & 2.39 & 0.65 & 0.81 & 1.08 & 1211 & 4.64 & NA & 93 & NA & NA \\
\hline 316-5W PRE & 5 & 0.38 & ND & 0.32 & 0.56 & 22 & 2.86 & NA & 15 & $\mathrm{NA}$ & $\mathrm{NA}$ \\
\hline
\end{tabular}

Source: DOE-RL 1994 
Table 4-4. Radionuclide Dose-Based Concentrations.

2

3

4

5

6

7

8

9

10

11

12

13

14

\begin{tabular}{|l|c|c|c|c|}
\hline \multirow{2}{*}{ Radionuclide } & \multicolumn{5}{|c|}{$\begin{array}{c}\text { Concentration associated with annual } \\
\text { dose limit (pCi/g) }\end{array}$} \\
\cline { 2 - 5 } & $3 \mathrm{mrem}$ & $10 \mathrm{mrem}$ & $15 \mathrm{mrem}$ & $25 \mathrm{mrem}$ \\
\hline Cobalt-60 & 0.7 & 2.4 & 3.5 & 5.8 \\
\hline Uranium-234 & 6.1 & 22 & 30 & 51 \\
\hline Uranium-238 & 18 & 61 & 89 & 150 \\
\hline
\end{tabular}

Source: DOE-RL 1994.

Attaining these cleanup levels ensures achieving

the associated dose limit at each waste management unit. Annual doses of $3,10,15$, and $25 \mathrm{mrem}$ are associated with ICRs of 4E-05, 1E-04, 2E-04, and $3 E-04$, respectively (based on a risk factor of 6.2E-per millirem and an industrial receptor exposure duration of 20 years). 


\section{CONTENTS}

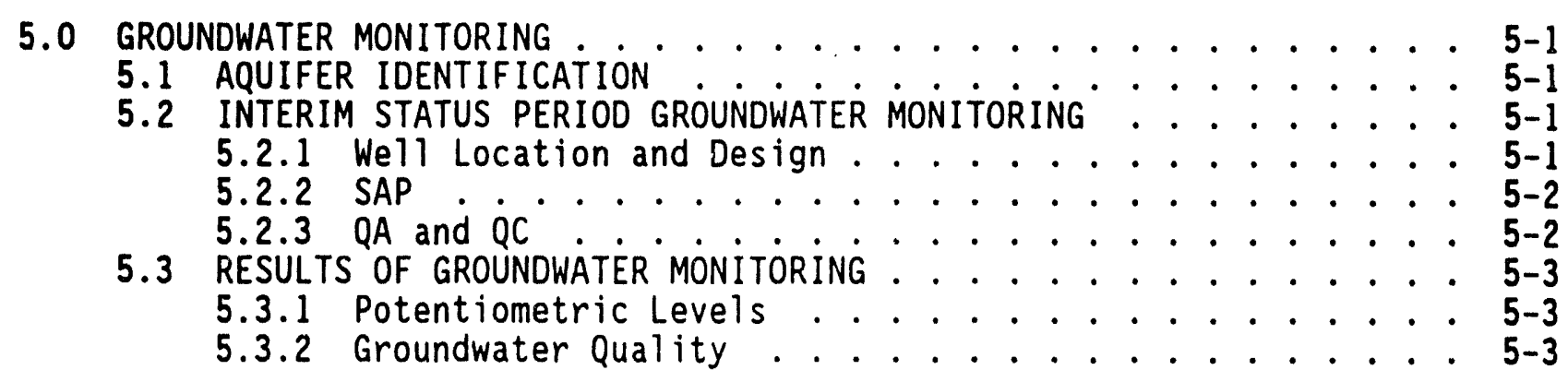

\section{FIGURE}

5-1. Well Locations . . . . . . . . . . . . . F5-1

\section{TABLE}

5-1. Monitoring Well for the 300 APT Network. . . . . . . . . T5-1

\section{APPENDIX}

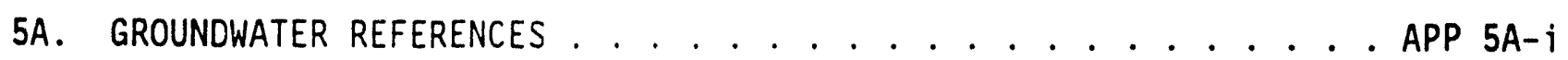


This page intentionally left blank. 


\subsection{GROUNDWATER MONITORING}

This chapter describes the groundwater monitoring program at the 300 APT site, including well location, hydrogeologic characterization, and data collection. Current knowledge of the site hydrogeology and groundwater quality is summarized.

\subsection{AQUIFER IDENTIFICATION}

The uppermost aquifer within the 300 Area is contained within the gravel and sands of the Hanford formation and the Ringold Formation. The geologic and hydrologic characteristics of these deposits are describe in Swanson et al. (1992) and Schalla et al. (1988b).

Unconfined and confined hydraulic conditions are present in the area. Beneath the process trenches, the water table is within the Ringold Formation at a depth of 10.7 meters (35 feet). At a depth of about 42.7 meters (140 feet) is the Ringold lower mud unit, approximately 9.1 meters (30 feet) thick, which acts as a confining layer. The hydraulic head of the confined aquifer beneath the lower mud is about 9.1 meters (30 feet) higher than that of the unconfined aquifer. This fine unit decreas's in thickness and pinches out to the north of the process trenches.

Transmissivity of the unconfined aquifer within the 300 Area was determined by aquifer tests and is reported in Swanson et al. (1992) and Schalla et a7. (1988b). Transmissivity ranges between 368 and 9,200 square meters $(4,000$ and 100,000 square feet) per day. Flow velocity estimated from sampling of the perchioroethylene spill was about 10.7 meters (35 feet) per day.

\subsection{INTERIM STATUS PERIOD GROUNDWATER MONITORING}

The RCRA Compliance Groundwater Monitoring Project for the 300 APT was initiated in June 1985. This project was designed as an assessment-level program for interim status facilities. The applicable monitoring requirements are described in 40 CFR 265 and WAC 173-303-645. A full description of the groundwater monitoring program is contained in the Revised Ground-Water Monitoring Compliance Plan for the 300 Area Process Trenches (Schalla et a1. 1988a).

\subsubsection{Well Location and Design}

The RCRA groundwater quality monitoring network for the 300 APT is currently comprised of 11 wells. The locations of the wells are shown in Figure 5-1. Two wells are upgradient of the trenches, three wells are adjacent to the trenches, and six wells are downgradient from the trenches. These wells monitor the uppermost aquifer system. Well information is summarized in Table 5-1. Wells were constructed to comply with WAC 173-160 
1

requirements. Geologist's logs for the monitoring wells are presented in Ground-Water Monitoring Compliance Projects for Hanford Site Facilities; Progress Report for the Period January I to March 1, 1987 (PNL 1987).

Forty-two wells within the 300 Area are measured monthly for depth to water. Elevation of the water surface in the wells is computed from the monthly water level measurements and measurements taken before sampling. These data are published in the RCRA quarterly reports and used to determine groundwater flow direction and gradient.

\subsubsection{SAP}

The revised Ground-Water Monitoring Compliance Plan for the 300 Area Process Trenches (Schalla et al. 1988a) describes groundwater sample collection, analysis, quality assurance (QA), and quality control (QC). Laboratory analytical methods are adapted from Test Methods for Evaluating Solid Waste: Physical/Chemical Methods (EPA 1990). Procedures for groundwater sample collection and field chemical measurements are contained in Procedures for Ground-Water Investigations (PNL 1989). Analytical methods, QA, QC measures, and DQOs are contained in the Quality Assurance Project Plan for RCRA Groundwater Monitoring Activities (WHC 1992a).

Sampling and analysis of the geologic materials and determination of aquifer properties occurred during the characterization of the site. Description of the hydrogeologic characterization activities and results are described in Schalla et al. (1988b). Aquifer and geologic properties are also described in Swanson et a1. (1992).

\subsection{3 $Q A$ and $Q C$}

The QC program for RCRA groundwater sampling and analysis includes internal laboratory checks and external checks. QA and QC for the 300 APT is part of the overall QA/QC program for RCRA groundwater monitoring for the Hanford Site facilities (WHC 1992). The program is based on Interim Guidelines and Specifications for Preparing Quality Assurance Project Plans (EPA 1983), RCRA Ground Water Monitoring Technical Enforcement Guidance Document (EPA 1986), and Test Methods for Evaluating Solid Waste: Physical/Chemical Methods (EPA 1990).

Procedures for collection and analys is of groundwater and geologic samples are contained in Environmental Investigations and Site Characterization Manua 7, WHC-CM-7-7 (WHC 1989) and Procedures for Ground-Water Investigations (PNL 1989). The data acquired from QC procedures are used to estimate and evaluate the information content of analytical data. The means used to estimate information content include precision, accuracy, detection limit, and other quantifiable and qualitative indicators (EPA 1990). Analytical results of $Q A / Q C$ are included in RCRA quarterly reports (Appendix 5A). 


\subsection{RESULTS OF GROUNDWATER MONITORING}

This section discusses the results of groundwater monitoring, including potentiometric levels and groundwater quality.

\subsubsection{Potentiometric Levels}

Water levels are monitored monthly in 42 wells throughout the 300 Area. These wells are completed both in the unconfined and confined aquifer beneath the 300 Area. The data have been presented in the RCRA quarterly reports, summarized in RCRA annual reports, and interpreted in the Phase I Remedial Investigation Report for the 300-FF-5 Operable Unit (DOE-RL 1993b).

The water level and flow direction in the unconfined aquifer within the 300 Area are primarily influenced by regional groundwater flow and fluctuations in river stage. The water level in wells monitoring the top of the unconfined aquifer near the river shore fluctuates as much as 1.2 meters (4 feet) over a l-year period. High stage occurs in late spring (May to June) and low stage in early fall (September to october). The groundwater flow direction of the unconfined aquifer is predominantiy to the southeast within the 300 Area in the area near the process trenches. Perturbations of the water level in the unconfined aquifer near the river shore occur when the river stage is higher than the water level in the unconfined aquifer. This river high usually occurs in late spring.

The confined aquifer is monitored at a few locations in and around the 300 Area. The direction of flow appears to be East-Northeast based on regional data. The potentiometric level of the confined aquifer is above land surface in well 699-S22-E9C and 0.6 to 1 meter ( 2 to 3 feet) below the land surface in well 399-1-17C. An upward gradient exists between the confined and unconfined aquifers.

\subsubsection{Groundwater Quality}

RCRA groundwater monitoring in the 300 Area was initiated in 1987 for the process trenches. Results and interpretation of these analyses are presented in RCRA quarterly and annual reports. The latest interpretation can be found in the RCRA annual report for calendar year 1993. The Annual Report for RCRA Groundwater Monitoring Projects at Hanford Site Facilities for 1992 (DOE-RL 1993e) has identified contaminants of potential concern for the unconfined aquifer beneath the CERCLA 300-FF-5 OU. These contaminants are: total coliform, chloroform, $1,2-$ dichloroethylene, trichloroethene, ${ }^{90} \mathrm{Sr},{ }^{99} \mathrm{Tc}$, tritium, total uranium, $234,235,238 \mathrm{U}$, nitrate, nickel, and copper.

The contaminants of concern 1 isted are below the DWS at the process trenches monitoring wells during 1993 except for 1,2-dichloroethylene. The September 1993 value of 1,2-dichloroethylene was 180 parts per billion in well 399-1-16B. Well 399-1-16B monitors the bottom of the unconfined aquifer. The DWS for 1,2-dichloroethylene is 70 and 100 parts per billion for its 
The contaminants of potential concern that can be associated with plumes within the 300 Area are ${ }^{90} \mathrm{Sr}$ and ${ }^{99} \mathrm{Tc}$, tritium, and total uranium. Plume diagrams are given in the RCRA annual report for calendar year 1993. The gross beta plume is associated with the contaminants ${ }^{90} \mathrm{Sr}$ and ${ }^{99} \mathrm{TC}$ and is centered in the northern part of the 300 Area. The tritium plume, which emanates from the 200 Areas, has reached the northern portion of the 300 Area at a level that is equal to the OWS of 20,000 picoCuries per 1iter ( 40 CFR 141). The uranium plume has two centers, one in the northern portion of the 300 Area near the process trenches, and the other located in the southeastern section of the 300 Area.

In 1991, an ERA was conducted on the process trenches to remove contaminated trench sediments. This action resulted in removal of about 1.2 meters ( 4 feet) of sediment beneath the inflow end of the trenches and removal of sediments along the berm separating the trenches (DOE-RL 1992a). Analytical results of subsequent groundwater monitoring indicated a decrease in uranium concentrations in samples collected from wel1 399-1-17A. Uranium values in groundwater collected from well 399-1-17A remain at lower values than before the ERA (DOE-RL 1993d).

There have been two unplanned releases of perchloroethylene to the trenches. The first occurred in November 1982 when about 455 liters (120 gallons) of perchloroethylene were spilled into the trench, and the second in July 1984 when about 76 liters ( 20 gallons) were spilled (Schalla et al. 1988a). The plume movement was monitored. Results of this monitoring and a description of the plume can be found in Schalla et al. (1988a). Perchloroethylene breaks down into the components trichloroethene and dichloroethene and vinyl chloride. These constituents are presently detected in well 399-1-16B.

A release of ethylene glycol to the process trenches occurred on April 30, 1993. A pipe failed within the 309 Building releasing about 1,364 liters (360 gallons) of antifreeze containing ethylene glycol, drained into a sump, and released to the process sewer line. Groundwater from selected wells was sampled during two separate sampling events in May 1993, and again in September 1993. Ethylene glycol was not detected in any of the groundwater samples. Results are presented in RCRA quarterly reports (Appendix 5A). 


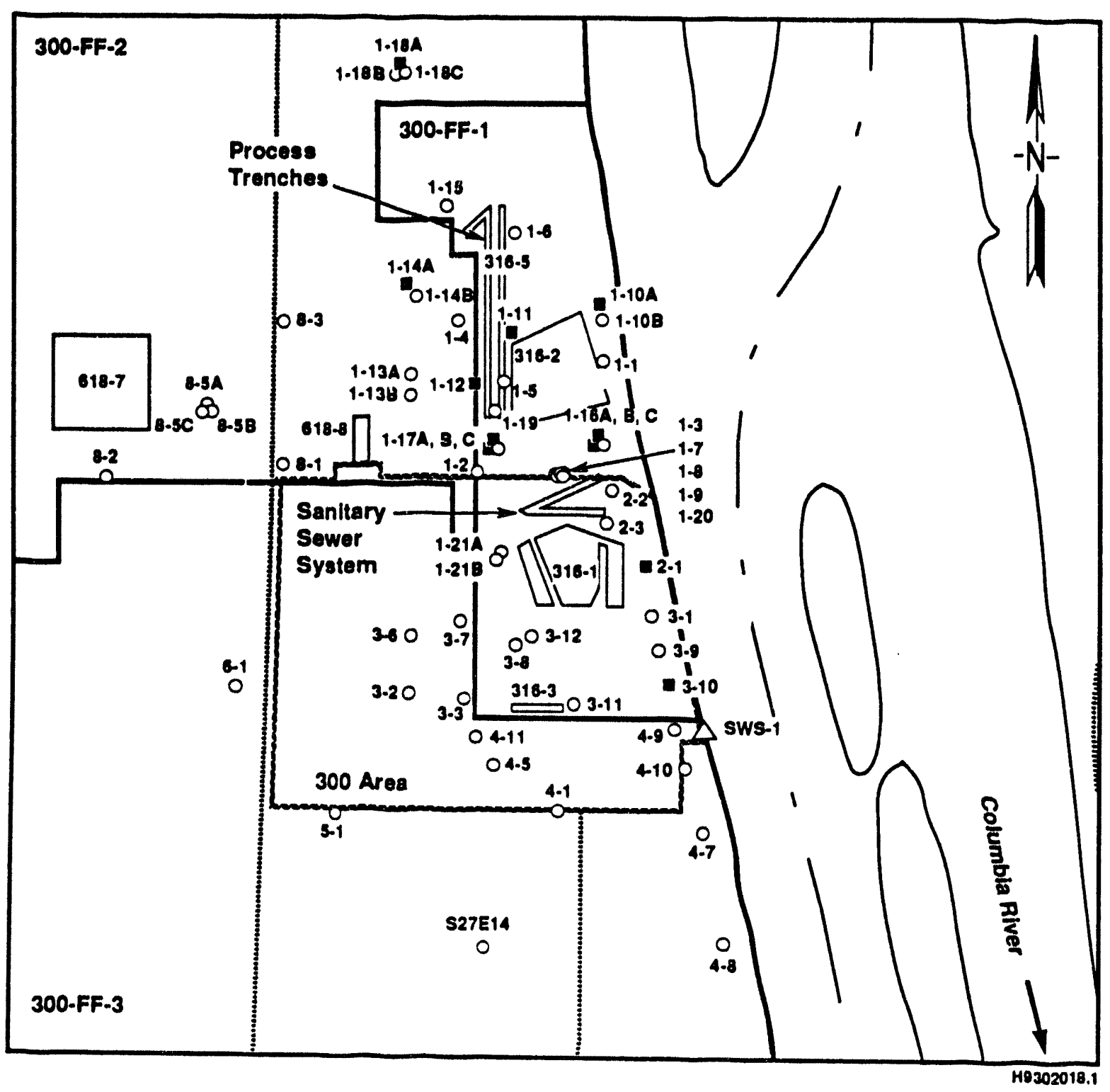
○ 1.12
- 4-7 Monltoring Network Well
$\Delta$ sws-1 Surface-Water Monitoring Station
Roads

Well Locatlon and Number (Wells Preflxed by 399.,

Except Those Beginning with S are Preflxed with 699-)

Figure 5-1. We11 Locations. 


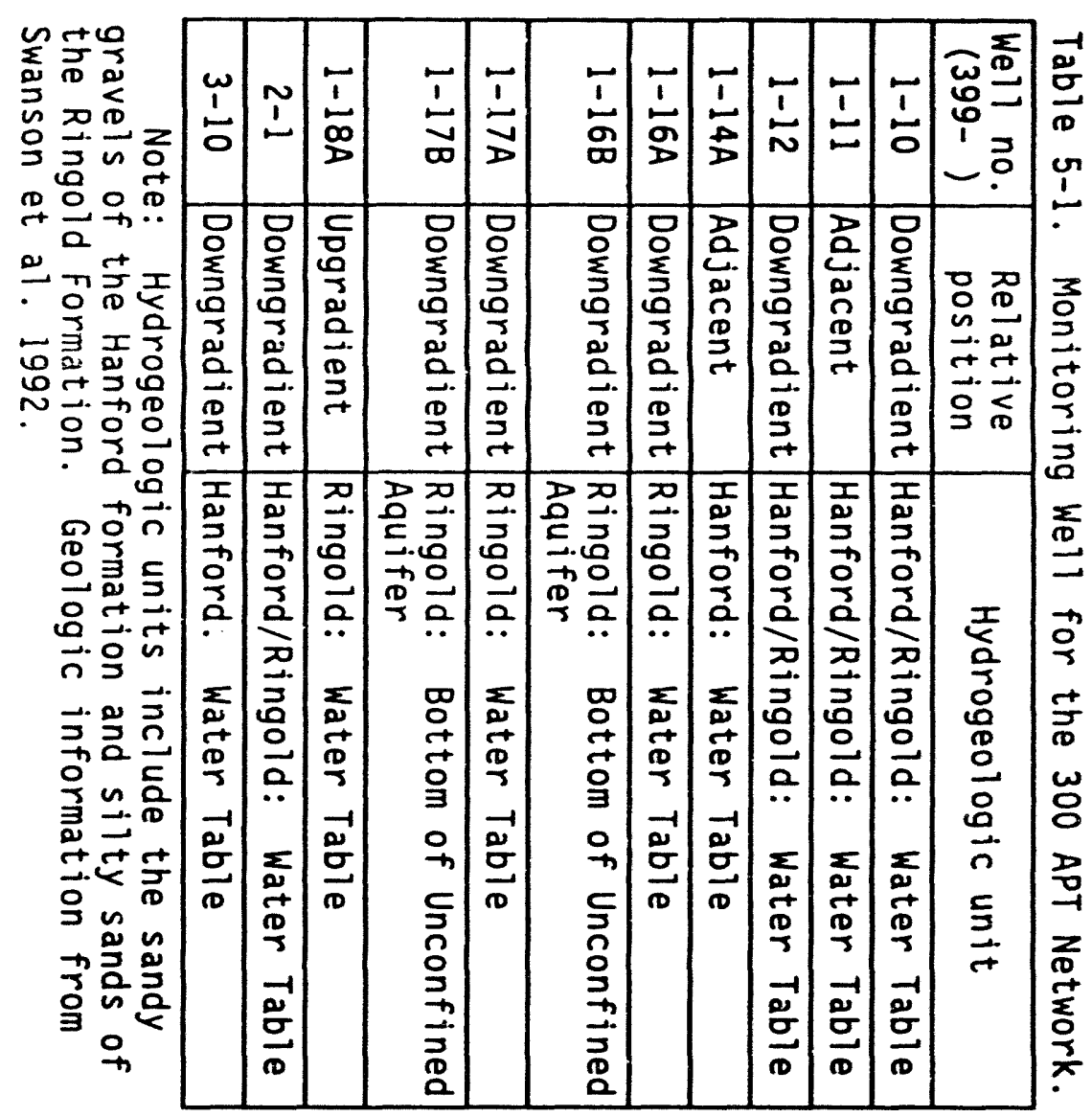




\section{CONTENTS}

6.0 ClOSURE STRATEGY AND PERFORMANCE STANDARDS . . . . . . . . . . $6-1$

6.1 CLOSURE STRATEGY . . . . . . . . . . . . . . . . . . 6-1

6.1.2 TSD Unit Closure Options . . . . . . . . . . . . 6-2

6.1.3 Groundwater Quality and TSD Unit Closure . . . . . . 6-3

6.2 CLOSURE PERFORMANCE STANDARDS ............... . . 6-4

6.2.1 Minimize the Need for Further Maintenance . . . . . . . . . . 6-4

6.2.2 Control Dangerous Waste to Escape to Protect Human

Health and the Environment . . . . . . . . . . . . . 6-4

6.2.3 Return nd to Appearance and Use of Surrounding Area . . . . 6-5

6.3 CLOSURE ACTIVITIES . . . . . . . . . . . . . . . 6-5

\section{FIGURE}

6.1 Closure Strategy . . . . . . . . . . . . . . . . . F6-1

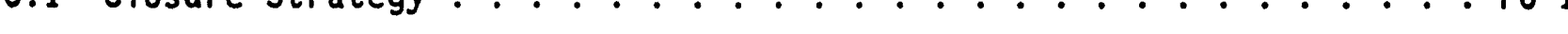


DOE/RL-93-73, Rev. 0

$08 / 15 / 94$

This page intentionally left blank. 
DOE/RL-93-73, Rev. 0

$08 / 15 / 94$

\subsection{CLOSURE STRATEGY AND PERFORMANCE STANDARDS}

This chapter describes the closure strategy, closure performance standards, and closure activities for the 300 APT TSD unit.

\subsection{CLOSURE STRATEGY}

The TSD unit is anticipated to undergo modified closure to industrial health-based cleanup standards. This is consistent with future land use of the 300 Area as an industrial site and with current contamination levels in unit soil. However, TSD unit closure will not occur until after soil and structure remediation at the unit. The cleanup levels achieved by TSD unit remediation could qualify the unit for clean closure. The modified and clean closure options are discussed in Section 6.1.2.

The strategy for performance of the physical activities required to close the unit will be as directed by the Tri-Party Agreement Action Plan (Ecology et a1. 1994). This requires 300 APT TSD unit physical closure activities to be integrated with the CERCLA RA process for the 300-FF-1 OU. For closure of the 300 APT TSD unit, the CERCLA OU will perform all necessary TSD unit physical closure activities, including soil and structure remediation, waste management, sampling and analysis, and postremediation care.

TSD unit soil cleanup levels and methods will be in accordance with the RA objectives (RAO) and the remediation methods specified in the ROD for the $300-F F-1$ OU. ROD specifications will be the regulators' decisions regarding soil cleanup levels and methods. The regulators' decisions will be based on information evolving from the CERCLA 300-FF-1 OU RI/FS process and as proposed in the Phase III FS. This RA will be protective of human health and the environment by meeting the objectives of reducing site risk to an acceptable leve1. RAOs for the 300-FF-1 OU are as follows (DOE-RL 1994).

- Reduce risk to the onsite industrial worker from exposure to contaminated soil or groundwater to an incremental cancer risk below $10^{-4}$ and a hazard quotient below 1.0. Alternatively for radionuclide contaminants, a dose-based approach could be used to establish acceptable residual soil concentrations.

- Control migration of contaminants from site soils to groundwater and to surface water via groundwater.

- Reduce risk to offsite recreational and residential receptors off of the Hanford Site to an incremental cancer risk below $10^{-6}$ and below a hazard quotient of 1.0 .

The CERCLA ROD will not be available until after submittal of Revision 0 of this closure plan to regulators. Consequently, final closure

specifications (e.g., cleanup levels, remediation methodology) are not as yet known to the closure process. Although the CERCLA unit will be performing TSD unit closure activities, documenting those activities to ensure that the TSD 
closure meets WAC 173-303-610 performance standards will remain the role of the RCRA closure plan.

\subsubsection{TSD Unit Closure Options}

It is not likely that the CERCLA ROD will specifically discuss RCRA TSD unit closure options (i.e., clean closure, modified closure). The RAOs specified in the RI/FS have been converted to preliminary remediation goals by the Phase III FS, the achievement of which will qualify the unit for one of these closure options. TSD unit closure options and the criteria for these closure options are described in this section. The logic used in arriving at the appropriate 300 APT TSD unit closure option is depicted in a flow diagram in Figure 6-1.

\subsubsection{Action Levels Relating to Closure Options. Action levels are} concentrations of analytes of interest that prompt an action (e.g., soil removal/treatment or further evaluation). They also can represent screening criteria for selection of the most appropriate TSD unit closure option of those presented in WAC 173-303-610 (i.e., clean closure) or in the Draft Hanford Facility Permit (Ecology 1994b) (i.e., modified closure).

Action levels can be background, limit of quantitation (LOQ), or HBL based on MTCA, WAC 173-340. HBLs are calculated by using chemical-specific variables for toxicity and carcinogenicity provided in EPA's Integrated Risk Information System (IRIS) database relating human health to action levels. The IRIS values are updated periodically and are used in the formulas of MTCA and/or HSBRAM, which are functionally equivalent in the calculation of dangerous waste HBLS for soil (Chapter 1.0, Section 1.2.3.2). The health-based soil cleanup levels will be based on the IRIS values that are current at the time of closure plan approval.

6.1.2.2 Clean Closure. Action levels that qualify the unit for clean closure are background as defined in Hanford Site Background: Part 1 Soil Background for Nonradioactive Analytes (DOE-RL 1992b), LOQ, which is defined as the level above which quantitative analysis can be obtained with a specific degree of confidence (generally the mean background value plus 10 standard deviations), and the MTCA Method B residential health-based soil cleanup levels found in WAC 173-340-740. Dangerous waste concentrations remaining in TSD unit soils, as identified in Table 4-1, currently exceed clean closure limits. Consequently, the unit cannot clean close without further soil remediation.

The 300-FF-1 OU is anticipated to remediate TSD unit soils for radionuclides. This remediation could reduce dangerous waste constituent concentrations to below clean closure limits. If postremediation sampling is performed that verifies clean closure levels, this closure plan will be revised.

In accordance with Section 6.3.1 of the Tri-Party Agreement Action Plan, if the closure plan also demonstrates that contaminants of concern to groundwater in unit soils also meet the clean closure criteria, groundwater monitoring in accordance with WAC 173-303-645 is not required. Certification 
DOE/RL-93-73, Rev. 0

$08 / 15 / 94$

of closure plan implementation will be provided to Ecology when clean closure activities are completed and the closure plan is updated. In this case, no postclosure care will be necessary and the unit-specific Part A Permit Application, Form 3 will be withdrawn.

6.1.2.3 Modified Closure. Current dangerous waste concentrations in TSD unit soils, as identified in Table 4-1, qual ify site soils for modified closure. The Draft Hanford Facility RCRA Permit (ECology 1994b) has identified the qualifying criteria for modified closure as MTCA Method C (WAC 173-340-745) industrial HBLs. The unit also qual ifies for modified closure under the conditions of MTCA (WAC 173-340-745) because of its current and anticipated future use as an industrial site. If the RCRA unit proceeds with modified closure as specified in the Draft RCRA Permit, the closure plan will be revised to reflect achievement of industrial HBLs. Certification of closure plan implementation will be provided to Ecology. The unit will then enter a modified closure period that will last until final closure conditions are met.

If the Hanford Facility RCRA Permit is finalized using the verbiage in the Draft RCRA Permit, modified closure will require unit care. This care will be described in Chapter 8.0 of the closure plan. This care will be initiated without a Postclosure Permit Application. Upon completion of modified closure care, certification of final closure to the standards reflected in the closure plan will be made and provided to Ecology. A petition to withdraw the facility-specific Part A Permit Application, Form 3, will be forwarded to Ecology.

6.1.2.4 Landfill Closure. As a surface impoundment, the 300 APT is required by WAC 173-303-610 to have a contingent closure plan. However, the unit is considered characterized and does not exceed modified closure levels for RCRA dangerous waste contaminants. Consequently, landfill closure will not be required for RCRA dangerous waste constituents. Further, al though excavation and surface barrier is a remedial alternative for the OU, such a barrier would be located at the North Process Pond, not at the TSD. Under this alternative, RCRA unit soils that are above RAOs for radionuclides would be excavated and relocated to the North Process Pond. Consequently, the RCRA unit would not be closing with waste in place above RAOs (DOE-RL 1994). Upon completion of excavation and relocation of TSD soils, certification of closure plan implementation would be provided to Ecology.

\subsubsection{Groundwater Quality and TSD Unit Closure}

In the past, groundwater quality has been affected by the operation of the 300 APT. Groundwater and 300-FF-1 subsurface soil [deeper than 4.6 meters (15 feet)] remediation is deferred to the CERCLA 300-FF-5 groundwater OU (DOE-RL 1992d). However, protection of groundwater by eliminating the migration of soil contamination is an RAO for the 300-FF-1 OU (Section 6.1).

The MTCA provides ARARs to the CERCLA activity requiring consideration of cross-media contamination and protection of groundwater from surface soil contamination. The Phase III FS approach is to control contaminant migration to groundwater by cleaning surface soils to reduce unit risk to below RAOs. 
This approach will also ensure that groundwater emerging as surface water, which could be used for drinking, will meet surface water quality standards of WAC-173-201A.

Groundwater monitoring (Chapter 5.0) indicates that nonradioactive contaminants of concern to the groundwater from the TSD unit, as identified in the Phase I RI for the 300-FF-5 (groundwater) OU (DOE-RL 1993b), are at or below DWS. The results of the 300-FF-5 RI indicate that contamination from the OU and TSD unit soils is not a major concern (DOE-RL 1993b). The Phase III FS (DOE-RL 1994) indicates that the contaminants of concern to the 300-FF-1 OU and the potential contaminants of concern for 300-FF-5 oU that are in surface soils cannot be transported to groundwater in sufficient quantities to exceed groundwater standards (DOE-RL 1994).

An assessment-level groundwater monitoring program (Schalla et al. 1988) for the 300 APT as an interim status TSD unit is underway. This will continue after TSD unit remediation under the following conditions: (1) as compliance monitoring during a modified closure period; (2) until the groundwater sampling results confirm that TSD unit constituents no longer adversely impact groundwater quality; or (3) until the ou confirms that groundwater is not contaminated. In accordance with Section 6.3.1 of the Tri-Party Agreement Action Plan, RCRA TSD unit clean closure will not occur during a period of groundwater monitoring under cases (1) and (2).

\subsection{CLOSURE PERFORMANCE STANDARDS}

The closure performance standards of WAC 173-303-610(2) require that the owner/operator of a TSD unit close the unit in a manner that: (1) minimizes the need for further maintenance; (2) controls, minimizes, or eliminates postclosure escape of dangerous waste to the extent necessary to protect human health and the environment; and (3) returns the land to the appearance and use of surrounding land areas.

\subsubsection{Minimize the Need for Further Maintenance}

The extent of future site maintenance depends on how the unit closes (i.e., clean, modified) after urit remediation for radionuclides. The initial closure level will depend on the cleanup levels achieved from unit

remediation. No further maintenance would be required under clean closure regardless of future land use. Maintenance, monitoring, and inspections would be necessary under modified closure as discussed in Chapter 8.0.

All remedial alternatives under consideration that are applicable to the TSD unit will control exposures and eliminate the escape of contaminants to the environment, as discussed in Chapter 7.0, Section 7.4.1.

\subsubsection{Control Dangerous Waste Escape to Protect Human Health and the Environment}

The roilowing actions have been taken in advance of closure activities to control and minimize dangerous waste at the unit. 
- Administrative measures were put in place in 1985 to eliminate all discharges of hazardous waste to the process sewer system.

- A groundwater monitoring network has been established around the facility (Schalla et al. 1988b).

- In the summer of 1991, an ERA was conducted at the site to reduce the future impacts of the contamination to groundwater. Contaminated sediments located at the bottom and sides of the trenches were excavated and relocated to impoundment areas within the TSD unit. Characterization and post-ERA soil sampling of both trenches were performed (DOE-RL 1992a).

- In January 1992, the flow rate to the process trenches was reduced to 1,137 liters (300 gallons) per minute. This was done to reduce potential impacts to groundwater and the Columbia River.

- The 300-FF-1 OU RI/FS has been conducted to determine the nature and extent of contamination within the TSD, and has provided alternatives for remediation.

The entire 300 Area, including the $300-F F-1$ OU and the 300 APT TSD unit location, is expected to remain an industrial area for the foreseeable future (DOE et al. 1992). Administrative controls will restrict public access, thereby eliminating risk to the general public. The RI has identified the only substantive risk as being to onsite industrial workers; their exposures will be administratively controlled.

\subsubsection{Return Land to Appearance and Use of Surrounding Area.}

The appearance and use of the 300 APT unit site after closure will be consistent with the future use of the property as an industrial site. If an immediate use of the property requiring the construction of impervious surfaces is not indicated, the area will likely be contoured to control drainage and revegetated.

\subsection{CLOSURE ACTIVITIES}

The following steps to closure consider only the remedial alternatives that are applicable to the TSD and are currently under consideration by the CERCLA remedy selection process (i.e., excavation and disposal, and excavation, soil washing, and fines disposal). These activities will be implemented during the RA phase by the RAWP and its support documents.

- TSD unit soil contamination will be remediated under CERCLA authority. The remedy and cleanup levels selected by the CERCLA ROIJ will protect human health from contact with soils or groundwater. TSD unit piping and structures will be demolished and removed to gain access to underlying unit soils for remediation. 
- TSD unit waste will be managed under CERCLA authority and stored and disposed of as agreed to with RCRA regulators.

- RCRA closure verification sampling (e.g., excavation sampling, in-process field screening) will be performed by CERCLA according to the approved 300-FF-1 OU SAP.

- The analytical results of TSD unit sampling will be evaluated by the CERCLA unit for achievement of RAOs and by the RCRA unit to determine the appropriate TSD unit closure option (i.e., clean or modified).

- Upon completion of the RA, the site will be restored (e.g., excavation(s) backfilled, recontoured, revegetated) as appropriate for future land use.

- Unit closure certification will be performed.

- Postremediation care for mod fied closure will be performed if necessary. Certification of final closure will be performed on completion of postremediation care.

Closure activities will be monitored by an independent registered professional engineer who will certify that closure activities were accomplished in accordance with the specifications of the approved closure plan. The certification will be sent by registered mail or an equivalent delivery service to Ecology and the EPA, Region $X$. The closure activities will be completed in accordance with the schedule contained in this plan (Chapter 7.0, Figure 7-2) after approval of this plan by the EPA and Ecology. 


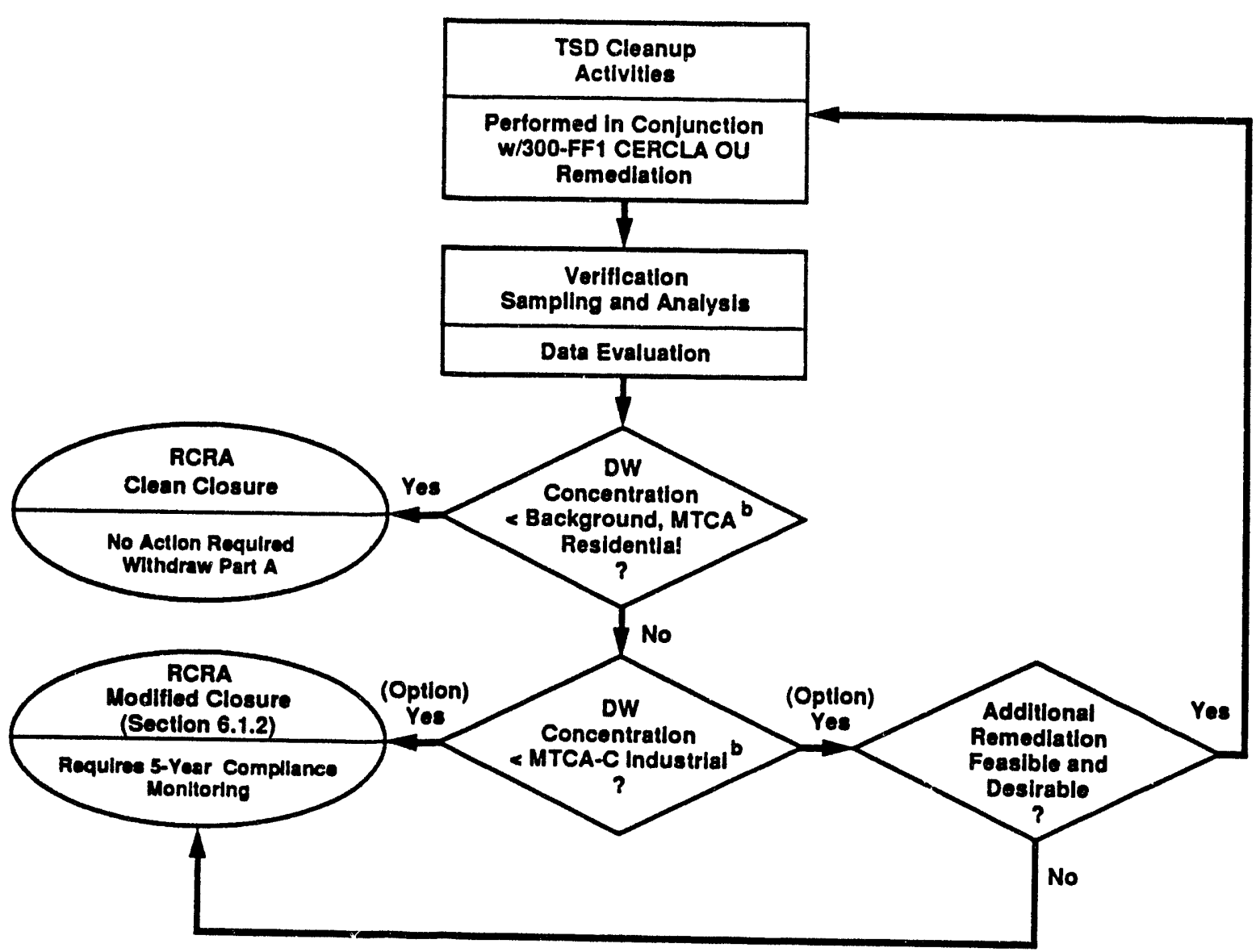

Note: TSD unlt is the sole source of dangerous waste.

b DW concentration already shown to be below MTCA-C Industrlal Standards.

Background = Hanford Slto-wide background threshold (upper limit range of concentrations) for soll (DOE-RL 1992b).

CERCLA = Comprohensive Environmental Response, Compensation, and Labillty Act of 1980.

Clean Closure = Closure based on the criterion that dangerous waste is not present in concentrations above the greater value of background, LOO, or residential; no further remedial action to be taken.

DW = Dangerous waste as defined in WAC 173-303.

$\mathrm{LOO}=$ Limit of quantitation; the level above which quantitstive analysis can be obtained with a specifled degree of confidence; generally $10 \sigma \pm 3 \sigma$. Modified Closure $=$ Closure based on the criterion that dangerous waste concentrations are greater than residentlal, but
less than or equal to Industrlal; compliance monitoring is required.

MTCA = Model Toxics Control ACt (WAC 173-304) residentlal and Industrial formulas.

RCRA = Resource Conservation and Recovery Act of 1976.

Figure 6-1. Closure Strategy. 


\section{CONTENTS}

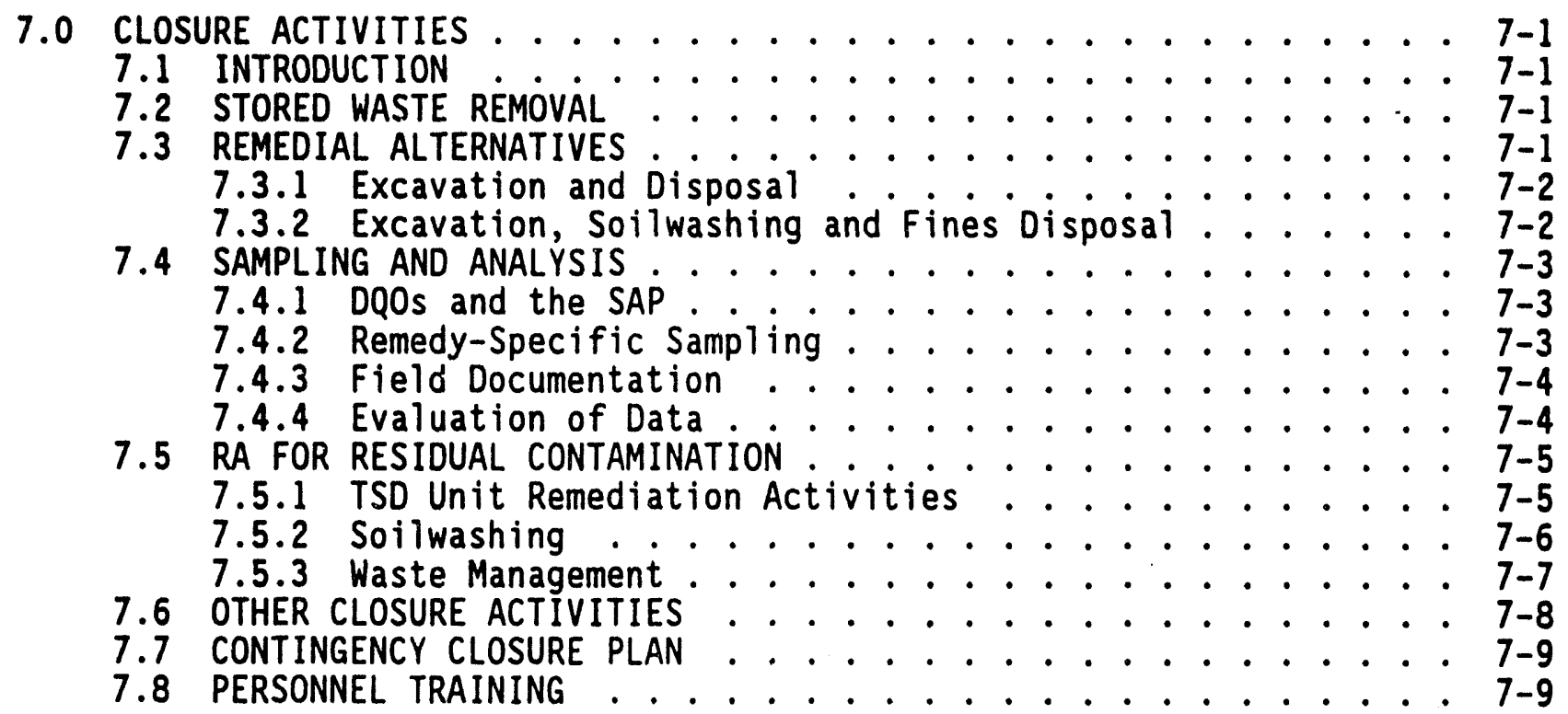

7.9 SCHEDULE OF CLOSURE . . . . . . . . . . . . . . . . . . . . . 7-9

7.10 AMENDMENT OF CLOSURE PLAN . . . . . . . . . . . . . . . . 7-10

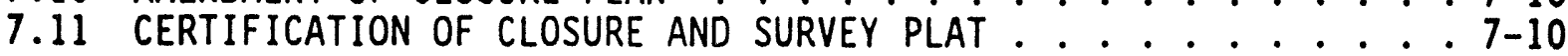

\section{APPENDICES}

7A SAMPLING AND ANALYSIS PLAN . . . . . . . . . . . . . APP 7A-i

7B SAMPLING DATA AND EVALUATION PACKAGE FOR THE 300 APT . . . . A APP 7B- $i$

7C TRAINING COURSE DESCRIPTIONS ................ APP 7C-

\section{FIGURES}

7-1. Soil Washing . . . . . . . . . . . . . . . . . . . . F7-1

7-2. Schedule for Closure . . . . . . . . . . . . . . . . . . . . F7-2

7-3. Typical Closure Certification Document . . . . . . . . . . . . F7-3 
UA WN

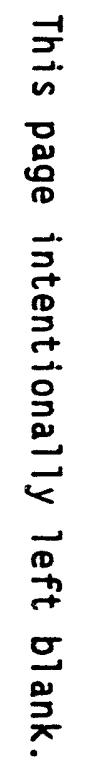

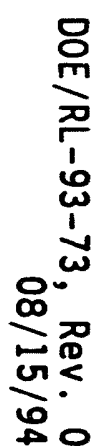


DOE/RL-93-73, Rev. 0

$08 / 15 / 94$

\subsection{CLOSURE ACTIVITIES}

This chapter discusses the activities that will be conducted to implement the strategy for closure of the 300 APT TSD unit described in Chapter 6.0 .

\subsection{INTRODUCTION}

The physical activities required to close the 300 APT TSD unit will be integrated with the CERCLA RA process for the 300-FF-1 OU. These activities will reflect the closure specifications stipulated in the ROD for the 300-FF-1 OU. ROD closure specifications are not yet available but are anticipated to follow Phase III FS proposals. The closure plan will present the physical remedial activities and sampling and analysis required for each alternative presented in the Phase III FS applicable to TSD unit closure. Groundwater remediation will not be addressed in this closure plan (Chapter 6.0, Section 6.1.3).

\subsection{STORED WASTE REMOVAL}

The 300 APT unit consists of two unlined, infiltration trenches. Only one of these, the east trench, is receiving nondangerous process liquid effluent from the 300 Area PS. The only process effluent presently at the unit is infiltrating into the soil column at the exireme south end of the east trench. There is currently no containerized waste requiring removal from the 300 APT TSD unit because none was stored there. No record exists of direct dumping of any other waste form (e.g., buried drums, contaminated equipment) at the trenches.

Contaminated unit soils and sediments were relocated within the TSD unit as a regulator-approved activity of the ERA (Chapter 2.0, Section 2.4). These remain at the unit in direct contact with the ground and are covered. These sediments are contaminated unit media, not stored waste, and will be remediated in a manner consistent with other unit soils.

After December 1994, liquid waste will no longer be discharged to the trenches. The trenches will then be allowed to dewater through percolation and evaporation. This will leave only residual soil and structure contamination by the time physical closure activities begin.

\subsection{REMEDIAL ALTERNATIVES}

The remedies being considered by the Phase III FS for TSD and OU contamination are excavation and surface barrier, excavation and disposal, and excavation, soilwashing, and fines disposal. All of these methods are described in detail in the Phase III FS Report (DOE-RL 1994). The remedy selection criteria used in preparing the list of alternatives included protection of human health and the environment; compliance with ARAR, long- 
term effectiveness; short-term effectiveness; reduction in mobility, toxicity, and volume; cost; state acceptance; and community acceptance (DOE-RL 1992d).

The excavation and surface barrier alternative will not be considered in the closure plan. Under this alternative, contaminated TSD unit and OU soils will be excavated and relocated to the North Process Pond and capped. This option would be functionally equivalent to excavation and disposal. This option would present waste management considerations addressed in Section 7.5.3.

Both TSD unit aiternatives will require short-term (during RA) and longterm (after RA) monitoring and institutional controls. Short-term monitoring is discussed in Section 7.5.1.1 and long-term monitoring is discussed in Chapter 8.0. All remedial alternatives applicable to the TSD unit will also share the common elements of excavation, transportation of contaminated soils, waste fixation, and waste disposal, as discussed in Section 7.5.1.

\subsubsection{Excavation and Disposal}

Excavation and disposal refers to the process of excavating and disposing of contaminated materials. This alternative is being considered where testing indicates that treatment may not be effective at achieving cleanup levels or is not cost effective.

7.3.2 Excavation, Soilwashing, and Fines Disposal. This alternative entails excavating contaminated soils, decontaminating the full volume of soil by onsite soilwashing, and disposing of the reduced volume of treatment waste (i.e., the fines).

Soilwashing, if selected, will take place at a mechanized plant within 300-FF-1 ou boundaries. Soilwashing (Figure 7-1) is an ex situ treatment process used to reduce waste volume by physically separating clean, coarse soils from the contaminated fines. The physical separation method currently under consideration does not use chemicals. In the 300 Area, the majority of contaminants reside on or within soil particles less than 100 microns in diameter. Soilwashing uses filtered recirculating wash water to assist in classifying (separating by size) contaminated fines (fine sand, silts, clay) from the less contaminated, coarser fraction (boulders, gravel, coarse sand) of the soil matrix. TSD unit soils are predominantly coarse sands and gravel, with less than 10 percent silts and clays, and are well suited to physical soilwashing. The contaminated fraction could be as little as 10 percent of the total volume treated (DOE-RL 1992f). This fraction will be disposed of as waste and the coarse fraction will be used as backfill. The process water is recycled within the treatment system and is supplemented with clean make-up water. Only when the process is complete will there be excess waste requiring treatment and disposal.

Two treatability tests for soilwashing were conducted by Westinghouse Hanford during 1993. Test results are published in the Phase II Remedial Investigation Report for the 300-FF-1 Operable Unit: Physical Separation of Soils Treatability Study (DOE-RL 1993C). A third test conducted in the spring 
DOE/RL-93-73, Rev. 0

$08 / 15 / 94$

of 1994 by a third-party vendor provides additional information (WHC 1994b). Test results and conclusions have been incorporated into the Phase III FS. These results have indicated that soilwashing can meet chemical and radionuclide cleanup specifications and can also meet the goal of 90 percent or greater volume reduction in waste requiring disposal (DOE-RL 1994).

\subsection{SAMPLING AND ANALYSIS}

Sampling of TSD unit media will be performed by the CERCLA sampling team in accordance with the approved CERCLA SAP and quality assurance project plan (QAPJP). The SAP/QAPJP will be initiated during the CERCLA RD phase, which occurs after receipt of the ROD. As directed in Section 7.8 of the Tri-Party Agreement Action Plan, CERCLA unit sample planning will follow a DQO process as does RCRA sampling (Ecology et al. 1994). The SAP will evolve from the DQO process and RCRA and CERCLA regulator agreements as guided by $300-F F-1$ ROD specifications and RCRA requirements. The DQO process, remedy-specific sampling, and data evaluation will be discussed in this section.

\subsubsection{DQOS and the SAP}

RCRA regulators will be involved with CERCLA regulators in the $D Q O$ process from which the CERCLA SAP will evolve. The method for involving RCRA regulators in the DQO process is discussed in Chapter 1.0, Section 1.2.4.

The DQO process wiil resolve TSD unit sampling issues such as; analytes of interest, sample location, number of samples, number and frequency of field QC samples (i.e., trip blanks, equipment blanks, splits, and duplicates), sampling methodology, analytical methods, laboratory protocols, laboratory QC samples (e.g., spikes, duplicates, reagent blanks, method check, and column check), sample validation, data error tolerances, acceptance of Sitewide background values (DOE-RL 1992b), and data evaluation methods. Sample handling, packaging, and shipping, chain of custody, and QC samples will be as required by internal, approved procedures (WHC 1989). A copy of the SAP and QAPjP, or portions applicable to the TSD unit closure, will be added to this closure plan as Appendix $7 \mathrm{~A}$ after approval.

\subsubsection{Remedy-Specific Sampling}

Sampling will be appropriate to the applicable remedial alternatives under consideration by the Phase III FS. These alternatives are excavation and disposal, and excavation, soilwashing, and fines disposal. Sampling for each alternative could reasonably proceed as follows.

7.4.2.1 Sampling for Excavation and Disposal. In-process excavation monitoring and field screening, postremediation excavation verification monitoring, and laboratory analytical verification sampling could be performed. The TSD unit excavation process will be guided by monitoring and field screening identified in the SAP. On completion of the excavation process, closure monitoring could be performed. Closure monitoring is similar 

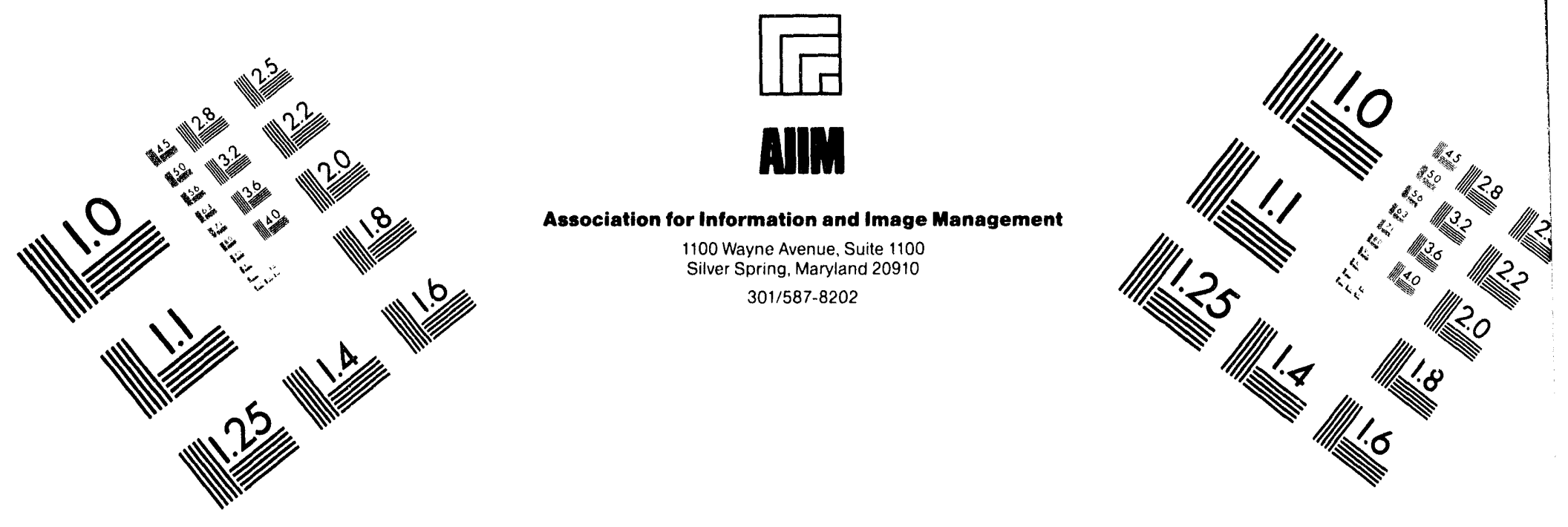

Centimeter

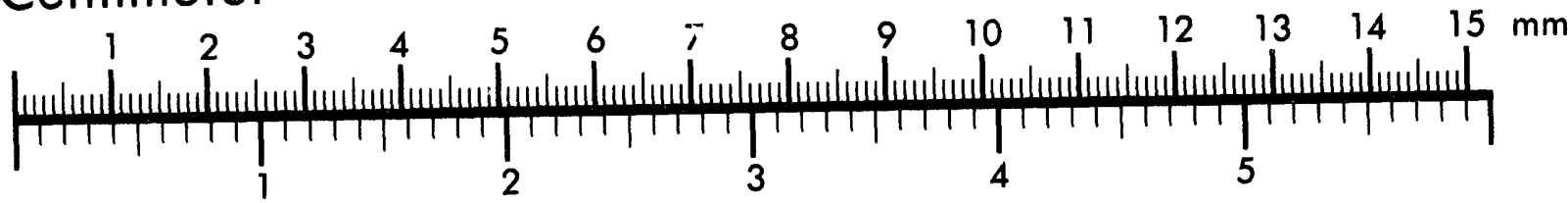
Inches
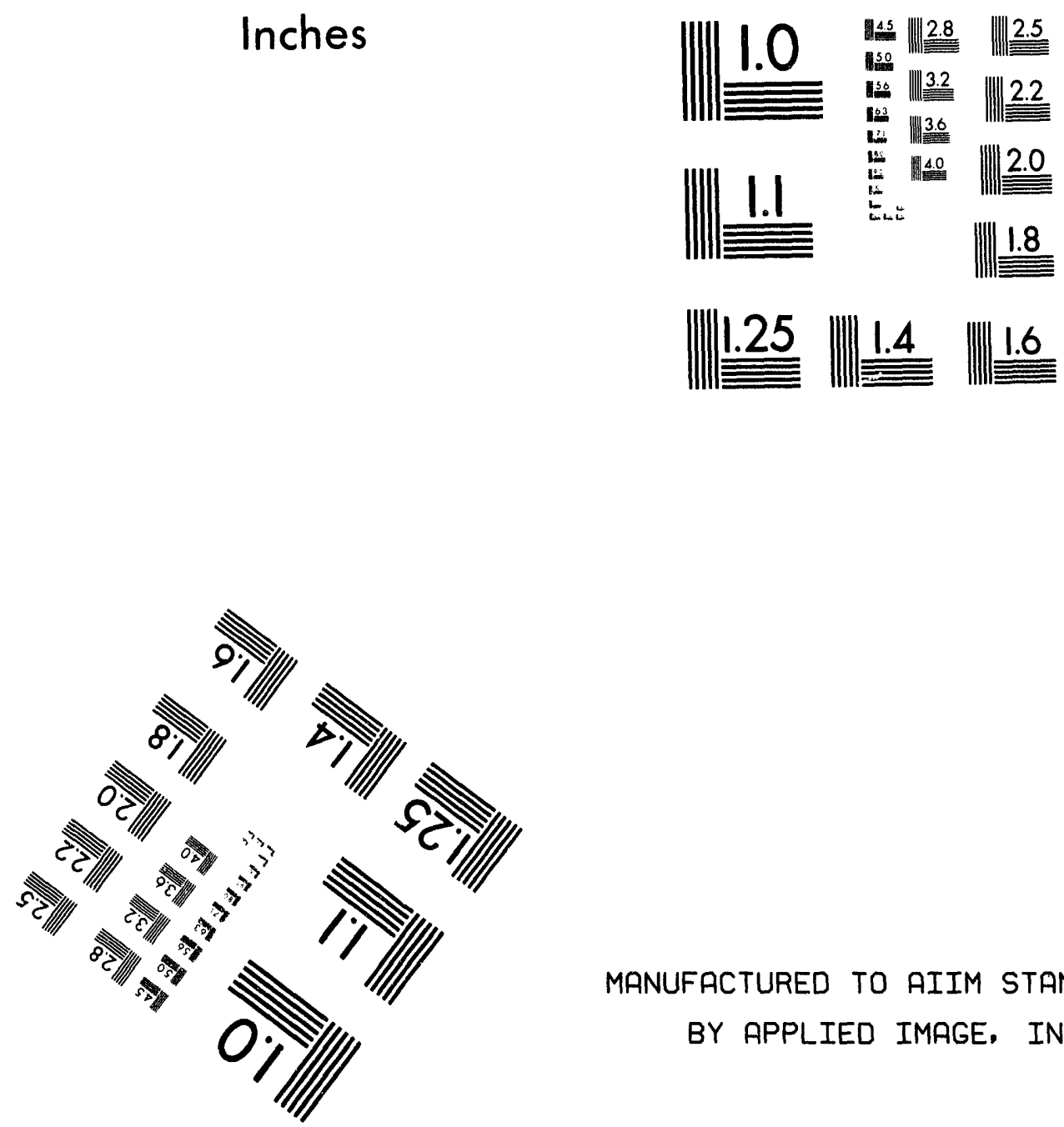

MANUFACTURED TO AIIM STANDARDS BY APPLIED IMAGE, INC.

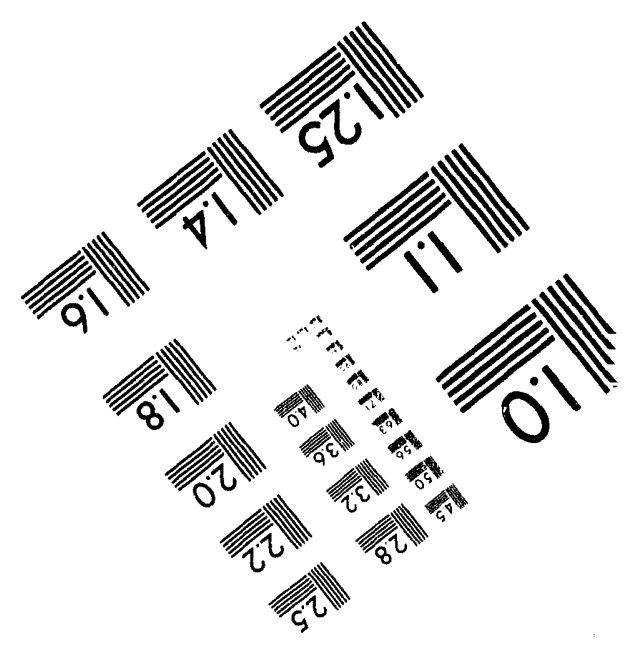



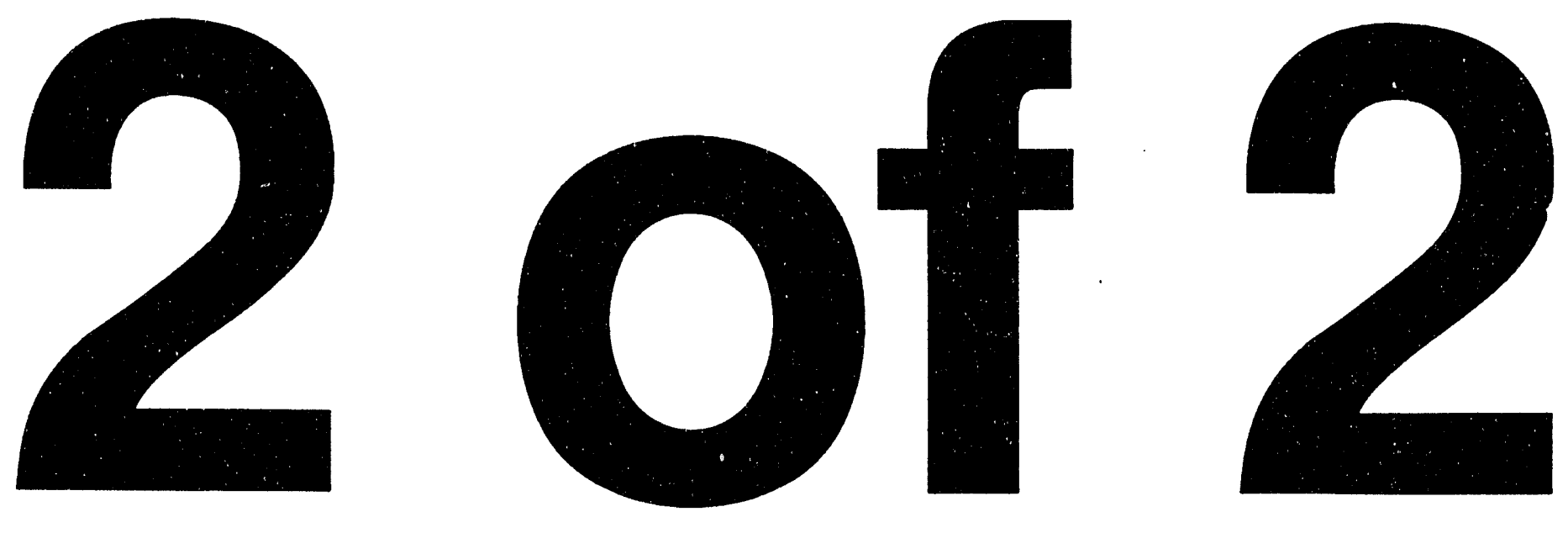
to the excavation monitoring methods employed during excavation except that detectors are adjusted to lower detection limits and in situ measurements are obtained over a dense sampling grid to ensure that the site meets cleanup criteria. Laboratory verification samples would be required at TSD unit excavations before backfilling to verify the absence of contamination above action levels. TSD unit structure demolition debris could require sampling for purposes of waste designation before disposal (Section 7.5.3).

\subsubsection{Sampling for Excavation, Soilwashing, and Fines Disposal. Sampling} for this alternative could include the in-process excavation monitoring and field screening, postremediation excavation verification monitoring, structure debris sampling, and laboratory sampling of excavations before backfilling, as described in Section 7.4.2.1.

During soilwashing, in-process field screening and monitoring should be performed to verify process efficiency for the remediated fraction as potential backfill material. Laboratory samples could be taken periodically to provide a higher $Q C$ confirmation of the field results. The process specifications for soilwashing should be specified in the SAP as a decision rule for determining when RAOs have been achieved and treatment may cease. Where in-process field screening and monitoring indicate that process specifications have not been met, the deficient fraction could be rerun or disposed of appropriately.

Sampling of the restored, backfilled trenches will not be required. The trenches will be backfilled using noncontaminated fill material from offsite or the product of the ons:te treatment process and then covered with clean soil. The remediated backfill material will already be shown to be below specified action levels and will require no further investigation.

\subsubsection{Field Documentation}

The CERCLA sampling field team leader will maintain a logbook during soil sampling activities in accordance with internal approved procedures (WHC 1989). Information pertinent to ongoing activities at the closure area will be recorded in the logbook in a legible manner with indelible ink.

\subsubsection{Evaluation of Data}

The CERCLA OU will evaluate all sampling analytical data obtained during $O U$ and TSD unit remediation. This evaluation will be performed using data analysis and evaluation procedures determined during the DQO process. The evaluation will be reviewed by RCRA and CERCLA regulators to verify the achievement of ROD- and DQO-prescribed action levels for all dangerous waste contaminants of concern to the T.SD unit.

The procedures for data evaluation results reporting will include a statistical analysis of analytical results and/or comparison of the final concentrations to RCRA closure option cleanup levels (Chapter 6.0,

52 Section 6.1). This evaluation, in support of RCRA closure option selection, 
will use laboratory detection limits, Hanford Site Background thresholds (DOE-RL 1992b), and specified HBLs as screening criteria. The sampling data package and the results of the evaluation report, as applicable to the TSD unit, will be incorporated into this closure plan as Appendix 7B as they become available.

\subsection{RA FOR RESIDUAL CONTAMINATION}

The 300-FF-1 Phase I and II FS (DOE-RL 1992e) examined several technologies and remedial alternatives for remediation of OU and TSD unit contamination. Data from the $300-F F-1$ RI was used to conduct a preliminary screening of alternatives. The Phase III FS has identified remedial a)ternatives (Section 7.3) and the preliminary remediation goals that can meet the RAOs. Implementation of these remedial alternatives is discussed in this section.

\subsubsection{TSD Unit Remediztion Activities}

RA alternatives are excavation and disposal, and excavation, soilwashing, and fines disposal. The activities common to each of these alternatives include: demolition and removal of unit piping, structures, and components; soil excavation; monitoring the excavation process; transportation of contaminated soils and debris; surface water management; waste fixation; and disposal of soils.

7.5.1.1 Demolition and Removal of TSD Piping, Structures, and Components. The TSD unit structures and equipment include the concrete weir box and the approximately 6.1 meters (20 feet) of 24-inch vitreous clay process sewer piping from the weir box to the TSD unit boundary fence. TSD unit piping and structures will be demolished and removed to gain access to underlying soils for removal or treatment. TSD unit structure debris that cannot be disposed of as remediation waste at the ERDF or under a surface barrier CERCLA must be sampled before disposal (Section 7.5.3).

The birdscreen and TSD unit boundary fencing (if removed) did not contact effluent and are not expected to be contaminated. However, they will be screened for contamination as indicated in the approved SAP. If contaminated, they will be disposed of as remediation waste. If not contaminated, they will be collapsed and disposed of in a landfill.

7.5.1.1.1 Monitoring. Short-term monitoring will be conducted during remediation to control adverse offsite side effects, provide QC, and evaluate performance of the remedy. Airborne dust or emissions are the primary offsite concern. Air sampling stations will be established around the perimeter of the 300 Area. Air samples will be routinely collected and analyzed. Other monitoring will include radiation monitoring for purposes of worker safety and process QC. The specifics of monitoring programs used for process QC purposes could be determined as a portion of the DQO process for the SAP, or could be determined through the appropriate CERCLA design documents. Site monitoring information will be added to the closure plan as available. 
7.5.1.1.2 Excavation. Soils would be excavated using backhoes and bulldozers to load trucks that will move soil to stockpiles. Depending upon the alternative selected, soils will be segregated as clean soil, contaminated soil for direct disposal, or contaminated soil for treatment. Segregation could be automated (e.g., by using conveyor belts). Shielded excavation equipment and/or reduced work shifts will be used to minimize radiation exposure. Excavation equipment will be decontaminated when remediation is complete. Dust suppression would include keeping open excavations and stockpiles to a minimum and using water sprayers to wet soil enough to prevent dust.

7.5.1.1.3 Transportation. Onsite transportation of excavated TSD unit soils to the treatment plant, clean stockpiles, or facilities for offsite loading will be by use of trucks or front-end loaders. Offsite shipment would be by truck or rail using suitable, covered, reusable bulk containers. The ERDF will be able to accept bulk containers. Transportation equipment would be dedicated and decontaminated at job completion. Worker exposures would be minimized as low as reasonably achievable (ALARA) by appropriate shielding and protective clothing.

7.5.1.1.4 Fixation. Fixation of soilwash fines or of a small portion of straight disposal waste will be performed in order to meet the ERDF waste acceptance criteria for uranium (DOE-RL 1994). This process entails crushing the soils to less than 0.75 inch ( 19 millimeters) and then mixing them with flyash, Portland cement, and water. Fixation will be as shown in Figure 7-5. Fixation will add approximately 20 percent to the volume of contaminated waste.

7.5.1.1.5 Surface Water Management. Little contaminated surface water is expected because of low precipitation and use of the best management practices in controlling surface water. Surface water from dust abatement or soilwashing will be controlled during site remediation to prevent the spread of contamination and minimize the amount of water contacting contaminated soil. All remediation alternatives for the TSD will include dikes and ditches to prevent run-on and run-off of surface water.

\subsubsection{Soilwashing}

If soilwashing is the selected remedy, it is anticipated that at a minimum, the north 91 meters (300 feet) of the pre-ERA trenches area will be extensively remediated. The areas and depths of excavation will be based on the required cleanup levels (Chapter 4.0, Section 4.3.3). The remaining trench areas, including structure and piping removal areas, as guided by SAPinitiated field screening, will likely require remediation to a lesser degree because of reduced, post-ERA contamination levels. Sampling will be performed in accordance with the approved SAP to ensure the achievement of treatment process specifications.

The treatment of 300 APT contaminated soils by soilwashing is envisioned to proceed generally as follows. 
- The areal extent of TSD unit excavation activities would be guided by approved field screening to ensure the removal of contamination to below action levels and to minimize unnecessary excavation.

- The TSD unit soils from the trenches, ERA impoundment areas, and structure and piping removal areas, would be excavated and transported by truck to the soilwashing plant for treatment.

- The remediated fraction (cobbles, gravel, and sand) would remain segregated from contaminants and be used as backfill material for the RCRA and CERCLA unit excavations and covered with 0.31 meter ( 1 foot) of clean soil.

- Contaminated fines and washwater filtration residues derived from soilwashing would be managed as CERCLA remediation waste while on the CERCLA site and disposed of at the ERDF or as discussed in Section 7.5.3. Before disposal, contaminated fines or residues from soilwashing will undergo fixation to meet ERDF acceptance criteria.

- Wash water will be recycled in the closed-loop treatment system and undergo filtration and treatment as needed before recycling. Make-up water will be added to compensate for loss through evaporation and absorption into the treated soil. Only when the remediation is complete, would there be excess process water remaining in equipment requiring treatment and disposal. Washwater would likely be evaporatively treated with residues and disposed of as remediation waste.

- The site will be restored (i.e., graded, contoured, and paved or revegetated) as guided by future land-use considerations and as specified in the governing work documents.

\subsubsection{Waste Management}

Characterization has indicated that dangerous waste constituents do not exist in TSD unit soils without the presence of radionuclides (DOE-RL 1992d). Consequently, remedial alternatives under consideration would generate TSD unit low-level radioactive or mixed waste that would require management and disposal under CERCLA authority.

The ERDF is scheduled under Tri-Party Agreement Milestone M-70-00 to be in operation to receive CERCLA remediation waste or RCRA corrective action waste by September 1996. The ERDF will be located in the 200 Area of the Hanford Site, approximately 32.18 kilometers $(20$ miles) northwest of the 300-FF-1 OU. The design for its liner(s) and final cover has not been finalized. The ERDF will have institutional controls including vadose zone and groundwater monitoring. The ERDF disposal offers the advantages over 300-FF-1 OU onsite containment of distance from population centers, distance from the Columbia River, and greater groundwater protection. The ERDF may receive TSD unit closure waste when such waste is designated in the ROD for the $300-F F-1$ OU as remediation waste. 
Currently, RCRA TSD unit closure waste is not within the definition of remediation waste and is not permitted for disposal in the ERDF. Assuming 300-FF-1 OU ROD designation of TSD unit closure waste as remediation waste (Chapter 1.0, Section 1.2.5.2), TSD unit closure waste (soil and structure debris and components) will go to the ERDF. If the excavation and surface barrier alternative were selected because of radionuclide contamination and given a remediation waste designation by regulators, all TSD unit waste could also be consolidated off the RCRA TSD unit site (at the North Process Pond) for capping.

Obtaining a contained-in determination from regulators will al so qualify TSD soils for ERDF disposal as being nondangerous (Chapter 4.0, Sections 4.1 and 4.3). However, unless TSD unit structure debris can be included in the contained-in determination, it will not qual ify for ERDF disposal. Structure and piping demolition debris would require sampling for waste designation before disposal at a RCRA-permitted mixed waste facility such as the W025 Facility in the 200 Areas.

TSD unit structure and piping demolition debris could be relocated off the RCRA site under an excavation and surface barrier alternative. Such waste would also likely carry the same codes for listed waste as do the soils. This waste could not permanently remain on the CERCLA site (North Process Pond) without a contained-in determination to remove its listing or without its designation as remediation waste.

Straight dangerous waste is not expected; however, if encountered, such waste would be transported to the 200 West Area 616 Storage Facility for eventual shipment to a RCRA-permitted TSD unit.

\subsection{OTHER CLOSURE ACTIVITIES}

Other TSD unit closure activities may be identified in future 300-FF-1 OU RA documents in support of TSD unit closure. As information regarding other TSD unit closure activities becomes available from the CERCLA document governing the activity, it will be incorporated onto the closure plan.

Equipment used during the remediation of the process trenches will be decontaminated in accordance with the appropriate CERCLA OU working documents.

\subsection{CONTINGENCY CLOSURE PLAN}

WAC 173-303-610 (3) requires that closure plans for surface impoundments, such as the 300 APT TSD unit, contain a contingency plan in case the unit must close with dangerous waste remaining above action levels. This contingency is normally identified as landfill closure. However, characterization sampling has indicated that RCRA soil contamination is below MTCA Method $C$ industrial levels that qualify the site for modified closure. If a containment cap is required, it will be because of CERCLA radionuclides and will not be located 
at the TSD unit (Section 7.3). Postclosure care requirements of such a cover are not stipulated in this closure plan.

\subsection{PERSONNEL TRAINING}

Appendix $7 \mathrm{C}$ contains a brief description of training courses. This training fulfills WAC 173-303-330 requirements for safety and site access training for work at a hazardous waste site containing both radioactive and dangerous waste hazards. All personnel entering the TSD unit during closure must have 40 hours of hazardous waste training.

Before performing actual closure activities, specific work plans will be submitted to the lead regulatory agency for review. These documents reference internal procedures that detail specific work activities and address personnel training (e.g., training required for soil sampling personnel). Work plans that detail the appropriate safety and personnel training (where considered necessary) will not be written until the applicable technology and specific materials and equipment are known.

\subsection{SCHEDULE OF CLOSURE}

Figure 7-2 reflects a typical closure plan review and approval schedule as presented in Figure 9-2 of the Tri-Party Agreement Action Plan. However, as an integrated activity, and in accordance with submittal schedules presented in Appendix $D$ of the Tri-Party Agreement Action Plan, RCRA closure plan preparation has been coordinated with preparation of the CERCLA Phase III Feasibility Study Report for the 300-FF-1 Operable Unit (DOE-RL 1994). These documents should remain on the same schedule for review, public comment, and finalization. In order to achieve coordinated review, a revised closure plan review cycle may be negotiated with the RCRA and CERCLA regulators.

Closure of the 300 APT will begin on notification by Ecology of closure plan approval. However, remediation activities in support of closure can begin before closure plan approval with prior notification from Ecology. office.

Official copies of the closure plan will be located at the following

Office of Environmental Assurance,

Permits, and Policy

U.S. Department of Energy

Richland Operations Office

Federal Building

825 Jadwin Avenue

P.0. Box 550

Richland, Washington 99352.

The DOE-RL will be responsible for amending this closure plan, as deemed necessary, according to the amendment procedures in WAC 173-303-610. The 
closure plan will be kept at the DOE-RL until closure is complete and certified.

\subsection{AMENDMENT OF CLOSURE PLAN}

The closure plan for the 300 APT will be amended whenever changes in operating plans or unit design affect the closure plan; whenever there is a change in the expected year of closure; or if, when conducting closure activities, unexpected events require a modification of the closure plan. The closure plan will be modified in accordance with WAC 173-303-610. This plan may be amended any time before certification of final closure of the $300 \mathrm{APT}$ TSD unit.

If an amendment to the approved closure plan is required, the DOE-RL will submit a written request to the lead regulatory agency to authorize a change to the approved plan. The written request will include a copy of the closure $\mathrm{pl}$ an amendment for approval.

\subsection{CERTIFICATION OF CLOSURE AND SURVEY PLAT}

In accordance with WAC 173-303-610 (6), within 60 days of closure of the 300 APT, the DOE-RL will submit to the Benton County Auditor and the lead regulatory agency, a certification of closure. The certification of closure will be signed by both the DOE-RL and a registered independent professional engineer, stating that the unit has been closed in accordance with the approved closure $\mathrm{plan}$. The certification will be submitted by registered mail or an equivalent delivery service. Documentation supporting the independent registered professional engineer's certification will be supplied upon request of the regulatory authority. The DOE-RL and the independent professional engineer will certify with a document similar to Figure 7-3.

The RA phase of the 300-FF-1 OU RA will include physical remediation of the 300 APT TSD unit. On completion of the RA phase (Figure 7-2), the EPA will issue a certification of completion to the DOE-RL for all or portions of the OU (Ecology et al. 1994). Before or during this period, consideration will be given to certifying the revision of the closure plan that implemented physical closure activities. If the unit has entered a modified closure status, a certification of the revision of the closure plan that implements modified closure compliance monitoring and the assessment activity will be forwarded to Ecology. Certification of final closure will be further required as discussed in Chapter 8.0, Section 8.8. 


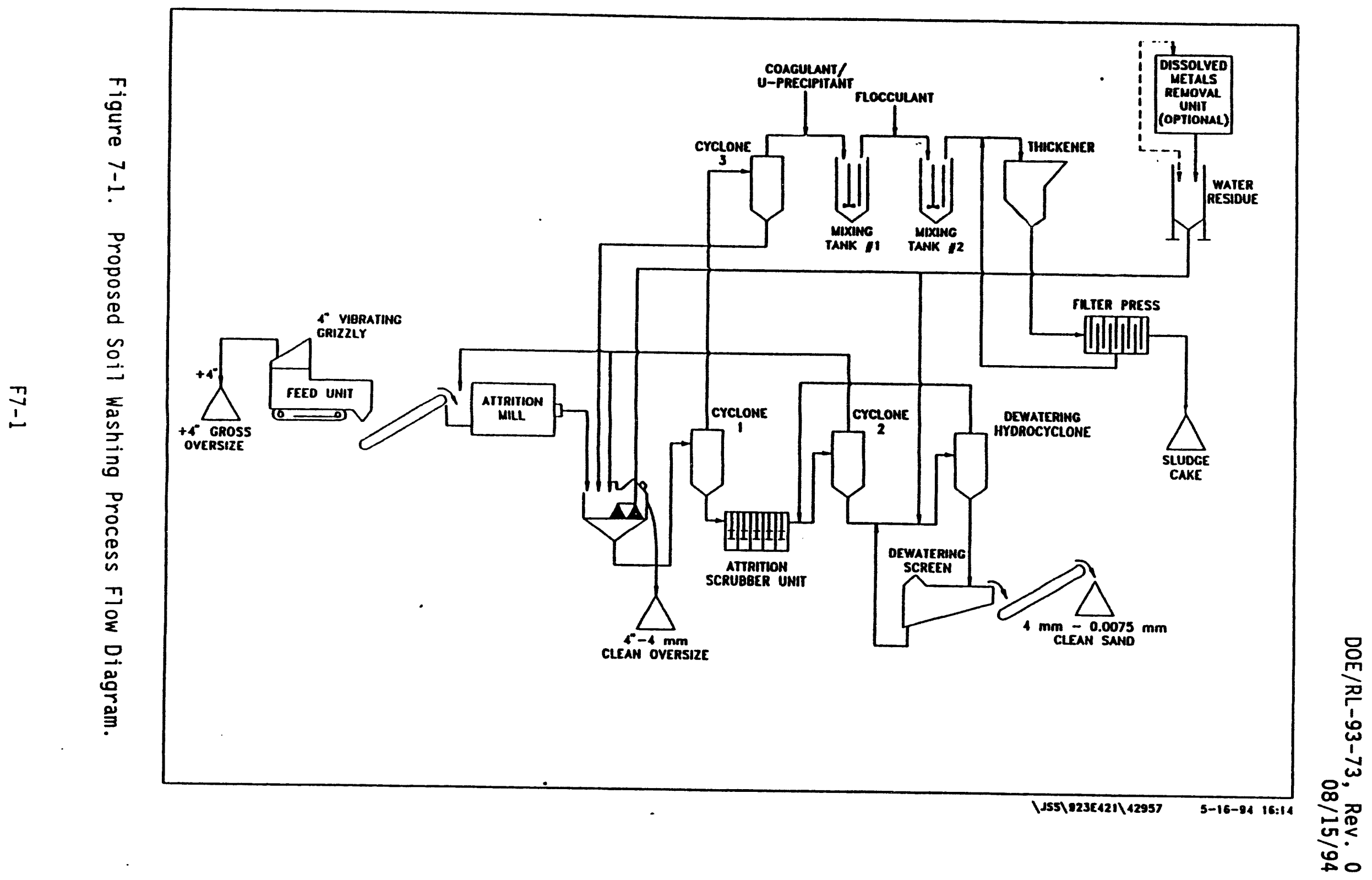


300 Area Process Trenches TSD Unit Closure Activity Schedule (1)

\begin{tabular}{|c|c|c|c|c|c|c|c|c|c|c|c|c|c|}
\hline Year & 1994 & 1995 & 1996 & 199 & 195 & & 1999 & 2000 & 2001 & 2002 & 2003 & 2004 & 2005 \\
\hline Ourtar & वाना & Thaा & & & & & & & & & & & \\
\hline
\end{tabular}

T.

ह

Resource Conservation and Recovery Act of 1976 (RCRA) Closure Plan Development

Submit Rovision 0

Submit Revision 1

Submil Revision 2 Page Changes

Public Roviow

Washington State Department of Ecology to lsewe Dratt Permit

300-FF-1 Remedial Action Process (3 Phases)

Submit Phase III Feasibility Study

Receivo 300-FF-1 Operable Unil (OU) Record of Decision

I. Phase I - Remedial Design

Interim Remedlal Measure Proposed Plan

- Remedial Design Report and Supporting Documents -

$\approx \quad$ Procurement Documents, Sampling Authortzation Form

Srocurement Documents, Sampling Authorization Form,
Sampling and Analysis Plan, Quality Assurance Projoct Plan?

Phase II - Remedial Action

- Remedial Actlon Work Plan and Support Documenta

- Cleanup of OU

- Cleanup of Treatment, Storage, and/or Disposal (TSD) Unit (2)

- Sampling - Analysis (1 mo.), Vallifation (3 mo.),

Data Evaluation Report (6 mo.) (4)

U.S. Environmental Protectlon Agency Cortlification of

2 Completton of Remodial Action Phase

O U.S. Department of Energy, Richland Operations Ottice

Phase III - Operation and Maintenance

- Initiate Operation and Mainiensence Plan and Support

Documents (as necessary)

OU Compllance Monitoring Plan, Including

TSD Unit Compllance Moniloring] (3)

DOE-RL Certification of Final TSD Closure

\section{$A=$ Event}

$\Delta$

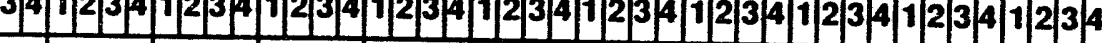

TSD unit closure activites integr

(2) TSD unit closure actlvities to begin upon approval of closure plan by RCRA regulators or with prior notification trom Ecology
(3) Assumes "moditied" closure to Model Toxics Control Act/Hanford Site Baseline Risk Assessment Methodology industrial stand

(Washington Administrative Code 173-340)

(4) TSD unit sampling pertormed by OU sampling team in accordance with the approved 300-FF-1 OU Sampllng and Analysis Plan/Ouality Assurance Project Plan 


\section{CLOSURE CERTIFICATION \\ FOR}

Hanford Site

U.S. Department of Energy, Richland Operations Office

We, the undersigned, hereby certify that all closure activities were performed in accordance with the specifications in the approved closure plan.

Owner/Operator Signature DOE-RL Representative (Typed Name)

\section{P.E.\#} State

Signature Independent Registered Professional Engineer (Typed Name, Washington State Professional Engineer license number, and date of signature)

Figure 7-3. Typical Closure Certification Document. 


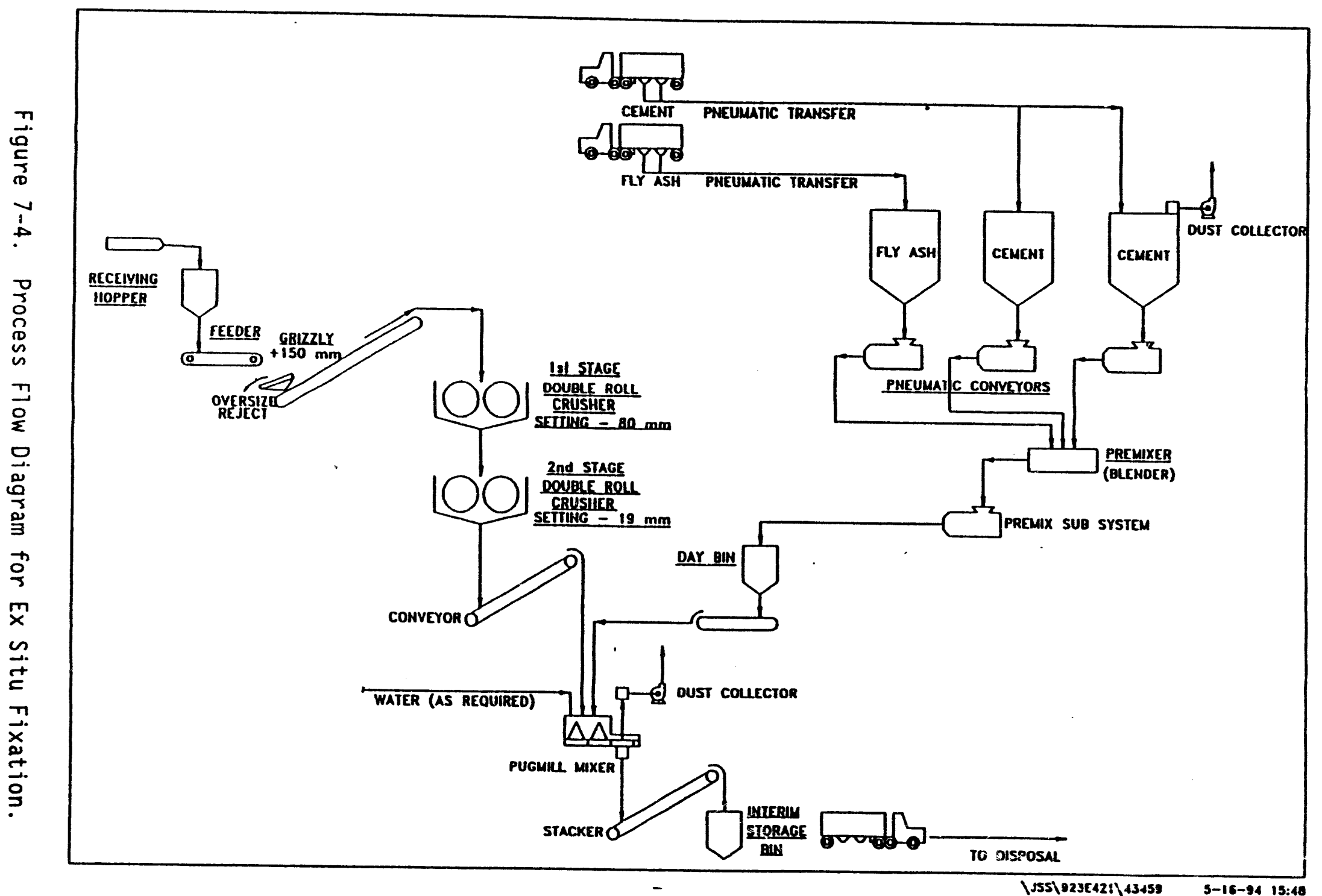




\section{CONTENTS}

8.0 MODIFIED CLOSURE CARE . . . . . . . . . . . . . 8-1

8.1 MODIFIED CLOSURE CARE REQUIREMENTS ............ 8-1

8.1.1 Institutional Controls . . . . . . . . . . . . 8-1

8.1.2 Periodic Assessments . . . . . . . . . 8-2

8.2 INSPECTION PLAN . . . . . . . . . . . . 8-2

8.2.1 Inspection Logbook ............... 8-3

8.2.2 Security Control Devices . . . . . . . . . . . 8-3

8.2.3 Well Condition ............ 8-3

8.2.4 Erosion Damage and Generai Integrity. . . . . . 8-4

8.3 GROUNDWATER MONITORING PLAN . . . . . . . . . . . . 8-4

8.4 MAINTENANCE PLAN . . . . . . . . . . . . . . 8-4

8.4.1 Repiir of Security Control Devices . . . . . . . . 8-5

8.4.2 Erosion Damage Repair ............. 8-5

8.4.3 Well Replacement ............... 8-5

8.5 PERSONNEL TRAINING ............... 8-5

8.5.1 Outline of the Training Program . . . . . . . 8-5

8.5.? Job Description ............... 8-5

8.5.3 Training Content, Frequency, and Techniques ..... 8-6,

8.5.4 Training Director ............. 8-7

8.5.5 Training for Emergency Response . . . . . . . 8-?

8.5.6 Implementation of Training Program . . . . . . . 8-8

8.6 PROCEDURES TO PREVENT HAZARDS . . . . . . . . . . . 8-8

8.6.1 Security. . . . . . . . . . . . . . . 8-8

8.7 CLOSURE CONTACT . . . . . . . . . . . . . . . . . .

8.8 CERTIFICATION OF MODIFIED CLOSURE CARE COMPLETION AND

FINAL CLOSURE . . . . . . . . . . . . 8- . .

TABLE

8-1. Inspection Schedule for the 300 APT. . . . . . . . . . T8-1 
DOE/RL-93-73, Rev. 0 $08 / 15 / 94$

This page intentionally left blank. 


\subsection{MODIFIED CLOSURE CARE}

Closure of a TSD unit with contamination remaining above clean closure levels but below MTCA (WAC 173-340-745) industrial HBLs, is identified in the Draft Hanford Facility Permit (Ecology 1994b) as modified closure (Chapter 6.0 , Section 6.1.2.3). This chapter is formulated on the possibility that the Hanford Facility RCRA Permit will be finalized using the verbiage in the Draft RCRA Permit (Ecology 1994b) RCRA postremediation care of the unit will be required for modified closure status. This care will begin after remediation is completed.

The inspections, maintenance, and monitoring requirements will be reflected in the revision of the closure $p l a n$ that implements physical closure activities. TSD unit care under the conditions of modified closure will also be documented as a portion of the O\&M Phase of the RA process. For the entire 300-FF-1 OU, the primary document implementing this phase is the O\&M Plan. Although CERCLA OU documents will originate the requirements for this care, such care must also meet the requirements for-modified closure compliance monitoring presented in this chapter. Other TSD unit closure care information will be added to this closure plan as it becomes available. Amendment of the compliance monitoring requirements of the closure plan will be in accordance with Chapter 7.0, Section 7.10.

The Draft Hanford Facility RCRA Permit does not identify the conditions of modified closure as postclosure care. The use of the term 'postclosure' reflects the need for a postclosure permit application, which is not applicable for this unit's status.

\subsection{MODIFIED CLOSURE CARE REQUIREMENTS}

The conditions of modified closure status are intended to guide the unit through controlled and protective transition period(s) of naturally declining contamination levels. The period(s) will end in the termination of modified closure and the initiation of final closure. Until final closure, modified closure must meet the requirements of institutional controls and periodic assessments of WAC 173-340-440 and -410 , respectively.

\subsubsection{Institutional Controls}

The institutional controls are required under WAC 173-340-440 during a period of modified closure, to ensure that control measures are maintained over time. These controls consist of physical measures and administrative and legal mechanisms. Fences and signs provide physical control of activities that may interfere with further RA or that may cause exposure to contamination at the site. As a legal mechanism, a restrictive covenant will be placed in the deed describing the institutional controls. The covenant will also prohibit site activities that interfere with cleanup, cause exposure to site contamination, or release hazardous substances. The covenant will also require that Ecology be notified of conveyance of interest in the property, or 
any proposal to use the site inconsistently with the covenant, and that Ecology be granted reasonable access for inspection. This covenant will be removed from the deed upon the termination of modified closure status and after a period of public notice and comment.

\subsubsection{Periodic Assessments}

Periodic assessments shall include a compliance monitoring plan in accordance with MTCA, WAC 173-340-410. Compliance monitoring will primarily involve protection and confirmation monitoring. This monitoring will ensure the continued effectiveness of modified closure in cuntrolling site contamination levels and protecting human health and the environment during the modified closure period. This monitoring is necessary to confirm compliance by demonstrating that contaminant levels found at time of closure have not increased.

As allowed by WAC 173-340-410, such monitoring may be combined with other plans or submittals. Confirmation monitoring for groundwater may be combined with the current joint RCRA/CERCLA program for the 300 Area. Protection monitoring is used to confirm that human health and the environment are adequately protected during this period and may be addressed in safety and health plans. The SAP should meet the requirements of WAC $173-340-820$ and provide for data evaluation, including a description of any statistical methods used.

Compliance monitoring will include routine visual inspections, maintenance, and groundwater monitoring similar to that identified in the following sections. The compliance monitoring plan will also include a timetable for performance of these activities. The plan shall provide for at least one assessment activity that will be performed after 5 years to ensure that contamination has remained at previous concentrations or has diminished in concentration. The plan will identify the nature and date of the assessment activity as an anticipated year of final closure. The requirements for the assessment activity will be contained in the CERCLA O\&M PI an and its support documents. This information will be incorporated into the closure plan as the CERCLA documents governing the activity become available.

The assessment activity could be comprised of visual inspections of the site for surface condition and usage (e.g., buildings, impervious surfaces), evaluation of existing data from the groundwater monitoring system, and/or other activities such as further limited soil sampling. If the contamination levels are shown to be the same or less than at the time of closure, the permittees may request that Ecology reduce or eliminate compliance activities, including institutional controls.

\subsection{INSPECTION PLAN}

This section describes compliance monitoring activities, security equipment, inspections for displacement, subsidence and erosion effects, and inspections for well conditions during a period of modified closure compliance 
monitoring. Table 8-1 lists the inspection items and the inspection frequency for the postclosure care period. These inspections may be implemented in checklist form. Such a checklist could specify entering checklist performance and results in the appropriate inspection logbook.

\subsubsection{Inspection Logbook}

Operations personnel will be conducting the inspections for site integrity, erosion, and security devices. Monitoring well conditions will be inspected by groundwater sampling personnel. The logbook will be issued and maintained for the entire period of closure monitoring by the site landlord in accordance with WHC-CM-7-7 or equivalent guidance.

Inspectors will be trained as identified in Section 8.5. The inspector will record any damage to the area and/or maintenance needs, as well as the weather conditions at the time of inspection. Separate logbook entries will be signed and dated. Performance of any related inspection checklists will be documented in the logbook. Maintenance actions will be started and should be completed within 90 days. Logbook entries will document the correction of the problem or the status of corrective actions. Entries should also uniquely identify, where possible, work documents that actually performed the activities.

\subsubsection{Security Control Devices}

The 300 APT is surrounded by a metal wire fence with a locked gate that is likely to remain in place during a period of modified TSD unit closure.

Each of the groundwater monitoring wells has a locked cap to prevent tampering. The wells also are surrounded by four steel guard posts to prevent damage from vehicles. The overall well condition, locks, guard posts, and pumps will be inspected during each sampling event. Problems and/or damage that is noted on the sampling log will be transferred to the field logbook for tracking of repairs.

\subsubsection{Well Condition}

Inspection of groundwater monitoring wells will be carried out under internal procedure WHC-CM-7-7 (WHC 1989) or equivalent guidance. This procedure calls for a surface inspection of a well at each sampling event. The procedure also calls for a subsurface inspection of the well at a minimum of every 3 to 5 years. This routine subsurface inspection will consist of pulling and inspecting the pump, brushing the inner walls of the casing and screen, and conducting a down-hole television survey. 


\subsubsection{Erosion Damage and General Integrity}

The 300 APT will be inspected quarterly by physically walking over the site to visually check for wind and water erosion, subsidence, displacement, and general site integrity. Any site damage noted during inspections will be recorded in the field logbook and reported to the appropriate maintenance authority. Major site damage will be reported to Ecology within 30 days.

\subsection{GROUNDWATER MONITORING PLAN}

Groundwater monitoring, in accordance with MTCA, WAC 173-340, will be required as a condition of modified closure. The current joint RCRA/CERCLA program (Chapter 5.0) will be assessed to ensure that it meets site monitoring needs and a revised plan will be prepared and submitted for approval, if necessary. This assessment wi1: include an evaluation of the monitoring well network in relation to the groundwater flow direction and the constituents selected for analysis. Groundwater samples will be collected semiannually under an interim status detection program. Indicator parameters from downgradient wells will be statistically compared to parameters from upgradient wells to determine whether the 300 APT might be affecting groundwater quality [40 CFR 265.93 (b and c)].

A groundwater quality assessment program will be instated if there is evidence that the 300 APT unit is adversely affecting groundwater quality [40 CFR 265.93 (d)]. In that event, an assessment plan will be prepared and submitted to the regulators for approval.

Until final RCRA closure of the 300 APT, the regulators will continue to receive quarterly reports following current reporting requirements. The Annual Report for RCRA Groundwater Monitoring Projects at Hanford Site Facilities (DOE-RL 1993), which includes the 300 APT, will also continue to be submitted to the regulators. The annual report interprets groundwater quality data (including statistical comparisons of upgradient and downgradient indicator parameters), water levels, and reviews the adequacy of the network relative to changes in the groundwater system. If data indicate that the current network is no longer adequate, an amended groundwater monitoring plan will be prepared describing steps necessary to rectify inadequacies, including the installation of additional wells.

\subsection{MAINTENANCE PLAN}

This section provides a plan for maintenance of the unit during the compliance monitoring period required for modified closure. Elements of this maintenance plan include repair of secunity devices, erosion damage, correction of subsidence or displacement, and well replacement. The maintenance $\mathrm{plan}$ is based on observations made and recorded in the inspection logbook (Section 8.2.1) during site inspections. Except where immediate action is required, maintenance action will be initiated within 90 days of inspection and discovery. 


\subsubsection{Repair of Security Control Devices}

The responsible maintenance organization will be notified of any problems to the well locks or guard posts and/or problems noted in the logbook during inspections and/or well monitoring activities. Well repairs will be made as soon as possible after notification of damage. Repairs to the four steel guard posts at each monitoring well will be made before the following inspection period and tracked in the logbook to completion.

\subsubsection{Erosion Damage Repair}

Any erosion damage noted during the inspections will be properly noted in the inspection logbook and reported to the responsible maintenance organization. Major erosion damage repairs will be initiated immediately using grading equipment, fill soils, and revegetation, as appropriate. Minor damage can be repaired using hand tools and should be initiated within 90 days of notification. Timely repairs will minimize the extent of erosion and should return the site surfaces to predamaged conditions as much as practicable.

\subsubsection{Well Replacement}

Maintenance of groundwater monitoring wells will be carried out under internal procedure WHC-CM-7-7 (WHC 1989) or equivalent guidance. This procedure covers correction of problems found during routine inspection or that manifest themselves at other times. If field maintenance procedures are inadequate to solve problems identified during site inspection, mainagement will decide whether to repair or replace the well.

Where monitoring well damage requires modification of the groundwater monitoring program, the monitoring plan will be amended in accordance with WAC $173-303-610$ (8) (d).

\subsection{PERSONNEL TRAINING}

This section describes the training of personnel required to maintain the $300 \mathrm{APT}$ in a safe and secure manner during postclosure care as required by 40 CFR 265.16 and WAC 173-303-330.

\subsubsection{Outline of the Training Program}

This section outlines the introductory and continuing training programs necessary to conduct the postclosure activities at the 300 APT in a safe manner. This section also includes a brief description of how training will be designed to meet job tasks as required in 40 CFR 265.16(a). 
Surveillance Personnel--The following outline provides information on classroom and on-the-job training that surveillance personnel will complete before conducting independent site surveillance at the 300 APT:

- Site surface inspections (water and wind erosion, settlement and displacement, vegetative cover)

- Security inspections

- Location, integrity, and inspection of benchmarks

- Location, integrity, and inspection of groundwater wells.

\subsubsection{Job Description}

This section provides the job description(s) for postclosure activities at 300 APT as required by 40 CFR 265.16(d)(1) and WAC 173-303-330(2)(a).

Site Surveillance--personnel with training in the following areas will conduct the inspections:

- Control devices

- Damage

- Settlement and displacement

- Vegetative cover condition

- Benchmark integrity.

\subsubsection{Training Content, Frequency, and Techniques} areas.

The training of personnel requires the following job-specific training

- Emergency Preparedness Training--This training will include a review of emergency procedures that consists of listening to standard emergency signals, emergency exit routing, job-specific emergency actions, and reporting procedures.

- The RCRA Groundwater Monitoring Scope, Organization, and QA Plan--This training will include the documentation requirements included in the chain of custody to the laboratory, how to correct mistakes made on field data sheets, and any applicable manifests or shipping orders required for shipping samples to the laboratory.

- Groundwater Field Sampling Procedures--This training will include pump description and operation of the three types of pumps (used by the field personnel), operational procedures for the generators and the pumps used to gather groundwater samples, and special requirements for collecting and packaging samples containing volatile organic materials that require acid preservatives or special filtering. Training also 
will be given in the areas of field data record preparation and chain of custody to the laboratory.

- Site Cover Inspections--This on-the-job training program is established to ensure that the surveillance personnel know what to inspect after closure of the 300 APT. The program will include how to inspect for obvious signs of erosion, proper drainage, settlement, and sedimentation. In addition, personnel will be informed about what constitutes proper vegetation coverage.

- Site Security Inspections--Personnel will be instructed on how to inspect for obvious signs of a security breach. Signs may include cut fencing, unlocked gates, cut chains, or downed barricades.

- Location, Integrity, and Inspection of Benchmarks--Personnel will be shown the location of benchmarks and instructed on how to report any obvious signs of destruction or deterioration.

- Location, Integrity, and Inspection of Groundwater Wells--Personnel will be shown the locations of the groundwater wells and instructed on how to inspect the cap and casing of each well to ensure that it is locked.

\subsubsection{Training Director}

The training director for the site surveillance personnel holds the title Manager of Safety Training. This position requires a Bachelor of Science degree in science or engineering with 10 years of experience in the nuclear industry or related areas and 5 years of management experience.

The objectives of this position include providing certification, recertification, and continuing training for all health physics technicians and providing general safety training for all personnel and other selected Hanford Site contractors, the DOE-RL, and visiting personnel working in Hanford Site facilities.

\subsubsection{Training for Emergency Response}

This section will demonstrate that personnel conducting postclosure activities at the 300 APT have been fully trained to respond effectively to emergencies and are familiar with emergency procedures and equipment. In addition, 40 hours of hazardous waste site operation training will be provided in accordance with 29 CFR 1910.120.

Procedures Regarding Emergency and Monitoring Equipment--The procedures for using, inspecting, repairing, and replacing emergency and monitoring equipment are covered as part of personnel training. The site surveillance personnel will undergo training in these areas. 
Response to Fires--The 300 APT will have no existing structures and will be covered with a soil cap if closed as a landfill. As such, there is no need for fire equipment. However, if personnel are at the unit when a brushfire breaks out, they will notify the Hanford Site Fire Department and the 200 East Area emergency control director by radio.

Response to Groundwater Contamination--Based on the current groundwater monitoring program, groundwater contamination beneath the 300 APT does not constitute an emergency situation, nor will it become so as a result of closure. Therefore, emergency response training in this regard is not warranted at this time.

\subsubsection{Implementation of Training Program}

Surveillance personnel will undergo the required training programs outlined in Section 8.4 .1 as they pertain to monitoring requirements. Surveillance personnel will not be allowed to perform inspections at the 300 APT until the required training programs have been completed.

\subsection{PROCEDURES TO PREVENT HAZARDS}

As required under 40 CFR 265.14 and WAC 173-303-310, the plan will describe procedures to prevent hazards from occurring at the closed unit. This section describes procedures to be used for ensuring proper security at the site including surveillance measures, intrusion barrier requirements, warning signs, and waiver declarations.

\subsubsection{Security}

Security will be maintained through routine surveillance, physical barriers, and warning signs that will remain in effect during the period of postclosure care required for modified closure.

8.6.1.1 24-hour Surveillance System. The 300 APT unit is located within the 300 Area of the Hanford Site. The 300 Area will remain an industrial, operational area of the Hanford Site for the foreseeable future. Operational areas will be under 24 hour surveillance by Hanford Patrol protective force personnel.

\subsubsection{Barrier, Means to Control Entry, and Warning Signs. As an} operational area of the Hanford Site, roadways to the unit and site access will remain administratively restricted to use by authorized personnel only. The unit is currently surrounded by a metal wire fence that is posted with warning signs reading "Danger - unauthorized personnel keep out." This fence is expected to remain in place during the modified closure care period. Access to the 300 Area from the Columbia River is restricted by posted federal warning signs. Further institutional and administrative measures controlling 
TSD unit site access may be initiated for the site commensurate with the future use of the property as an industrial area.

\subsection{CLOSURE CONTACT}

The following office will be the official contact for the 300 APT during the postclosure care period:

Office of Environmental Assurance,

Permits, and Policy

U.S. Department of Energy

Richland Operations Office

P.0. Box 550

Richland, Washington 99352

(509) 376-5411.

\subsection{CERTIFICATION OF MODIFIED CLOSURE CARE COMPLETION AND FINAL CLOSURE}

The sole source of regulatory direction for modified closure is Section II, $K$ of the Draft Hanford Facility RCRA Permit. The permit does not describe this period as a postclosure period. Completion of the final assessment activity that follows a compliance monitoring period will end the period of modified closure and allow final closure with regulator concurrence.

No later than 60 days after completion of the modified closure care period, the DOE-RL will submit to Ecology a certification of completion of closure care. This certification, stating that closure care for the unit was performed in accordance with the approved closure plan, will be signed by both the DOE-RL and an independent registered professional engineer. The certification will be submitted by registered mail or an equivalent delivery service. Documentation supporting the independent registered professional engineer's certification will be supplied upon request of the regulatory authority. The DOE-RL and the independent professional engineer will certify with a document similar to Figure 7-3. 
This page intentionally left blank. 
Table 8-1. Inspection Schedule for the 300 APT.

2

3

4

5

6

7

8

9

\begin{tabular}{|l|c|}
\hline \multicolumn{1}{|c|}{ Inspection item } & Inspection frequency \\
\hline $\begin{array}{l}\text { Security Control Devices: } \\
\text { fences, we11 caps, and locks }\end{array}$ & Quarterly \\
\hline Erosion Damage & Quarterly \\
\hline We11 Condition & Semiannually \\
\hline General Integrity & Quarterly \\
\hline Subsurface Well Condition & $3-5$ years \\
\hline
\end{tabular}


•

-

$\bullet$ 
9.0 REFERENCES ........................ . . . . . . . . . . 9.1 DOCUMENTS ........... . . 9-1

9.2 CODE OF FEDERAL REGULATIONS AND FEDERAL REGISTER $\ldots \ldots \ldots$

9.3 FEDERAL AND STATE ACTS . . . . . . . . . . . 9-6

9.4 WASHINGTON ADMINISTRATIVE CODE . . . . . . . . . . . . . . 9-6

9.5 THE U.S. DEPARTMENT OF ENERGY ORDERS . . . . . . . . . 9-7 
DOE/RL-93-73, Rev. 0 $08 / 15 / 94$

This page intentionally left blank. 
DOE/RL-93-73, Rev. 0

$08 / 15 / 94$

\subsection{REFERENCES}

References used throughout this closure plan are listed in this chapter.

\subsection{DOCUMENTS}

DOE, Ecology, EPA, 1992, The Future for Hanford: Uses and Cleanup - The Final Report of the Hanford Future Site Uses Working Group, December 1992, Hanford Site, Richland, Washington.

DOE-RL, 1988, Hanford Site Dangerous Waste Part A Permit Application, 3 vols., DOE/RL 88-21, U.S. Department of Energy-Richland Operations Office, Richland, Washington.

DOE-RL, 1990, Remedial Investigation/Feasibility Study Work Plan for the 300-FF-1 Operable Unit, Hanford Site, Richland, Washington, DOE/RL-88-31, U.S. Department of Energy-Richland Operations Office, Richland, Washington.

DOE-RL, 1991a, Expedited Response Action Proposal for the 316-5 Process Trenches, DOE/RL-91-11, U.S. Department of Energy, Richland Operations Office, kichland, Washington.

DOE-RL, 1991b, Hanford Site Waste Management Unit Report, DOE/RL-88-30, Rev. 1, U.S. Department of Energy Richland Field Office, Richland, Washington.

DOE-RL, 1992a, Expedited Response Action Assessment for the 316-5 Process Trenches, DOE/RL-92-32, Rev. O., U.S. Department of Energy, Richland Operations Office, Richland, Washington.

DOE-RL, 1992b, Hanford Site Background: Part 1, Soil Background for Nonradioactive Analytes, DOE/RL-92-24, Rev. 1, U.S. Department of Energy, Richland Operations Office, Richland, Washington.

DOE-RL, 1992C, Hanford Site Baseline Risk Assessment Methodology, DOE/RL-91-45, U.S. Department of Energy, Richland Operations Office, Richland, Washington.

DOE-RL, 1992d, Phase I Remedial Investigation Report for the 300-FF-1 Operable Unit, DOE/RL-92-43, Rev. 0, U.S. Department of Energy, Richland Operations Office, Richland, Washington.

DOE-RL, 1992e, Phase I and II Feasibility Study for the 300-FF-1 Operable Unit, DOE/RL-92-46, U.S. Department of Energy, Richland Operations Office, Richland, Washington. 
DOE-RL, 1993a, Hanford Site Waste Information Data System, 1993, U.S. Department of Energy, Richland Operations Office, Richland, Washington.

DOE-RL, 1993b, Phase I Remedial Investigation Report for the 300-FF-5 Operable Unit, DOE/RL-93-21, U.S. Department of Energy, Richland Operations Office, Richland, Washington.

DOE-RL, 1993C, Phase II Remedial Investigation Report for the 300-FF-1 Operable Unit; Physical Separation of Soils Treatability Study, DOE/RL-93-96, Rev. 0, U.S. Department of Energy, Richland Operations Office, Richland, Washington.

DOE-RL, 1993d, Annual Report for RCRA Groundwater Monitoring Projects at Hanford Site Facilities for 1993, DOE/RL-93-88, U.S. Department of Energy, Richland Operations Office, Richland, Washington.

DOE-RL, 1993e, Annual Report for RCRA Groundwater Monitoring Projects at Hanford Site Facilities for 1992, D0E/RL-93-09, U.S. Department of Energy, Richland, Washington.

DOE-RL 1994, Phase III Feasibility Study for the 300-FF-1 Operable Unit, DOE/RL-94-49, U.S. Department of Energy, Richland Operations Office, Richland, Washington.

Eaton, Tom, 1993, Contained-in policy, [Letter to all Ecology Hazardous Waste Staff], Washington State Department of Ecology, Olympia, Washington.

Ecology, EPA, and DOE, 1994, Hanford Federal Facility Agreement and Consent Order, 2 Vols., as amended, Washington State Department of Ecology, U.S. Environmental Protection Agency, and U.S. Department of Energy, Olympia, Washington.

Ecology, 1994a, Model Toxics Control Act Cleanup Levels and Risk Calculation (CLARC II), Update, March 1994, Washington State Department of Ecology.

Ecology, 1994b, Dangerous Waste Portion of the Resource Conservation and Recovery Act Permit for the Treatment, Storage, and Disposal of Dangerous Waste, Official Public Comment Version, February 2, 1994, Washington State Department of Ecology.

EPA, 1983, Interim Guidelines and Specifications for Preparing Quality Assurance Project Plans, QAMS-005/80, U.S. Environmental Protection Agency/Office of Exploratory Research, Washington, D.C.

EPA, 1986, RCRA Ground Water Monitoring Technical Enforcement Guidance Document (TEGD), OSWER-9950.1, U.S. Environmental Protection Agency, Washington, D.C. 
EPA, 1988, Guidance for Conducting Remedial Investigations and

Feasibility Studies under CERCLA, Interim Final, EPA/540/G-89/004, OSWER Directive 9355.3-01, U.S. Environmental Protection Agency, Washington, D.C.

EPA, 1989a, Risk Assessment Guidance for Superfund: Human Health Evaluation Manual, Vol. 1, EPA/540/1-89/004, U.S. Environmental Protection Agency, Washington, D.C.

EPA, 1989b, Risk Assessment Guidance for Superfund Volume II Environmental Evaluation Manual, EPA/540/1-89/001, U.S. Environmental Protection Agency, Washington, D.C.

EPA, 1990, Test Methods for Evaluating Solid Waste: Physical/Chemical Methods, SW-846, as amended, (Supplement 1990), U.S. Environmental Protection Agency, Washington, D.C.

EPA 1991, Integrated Risk Information System (IRIS), U.S. Environmental Protection Agency, Washington, D.C.

Evans, J.C., Bryce, R.W., and D.J. Bates, 1992,. Hanford Site Ground-Water Monitoring for 1991, PNL-8284, Pacific Northwest Laboratory, Richland, Washington.

HEDL, 1984, Hanford Engineering Development Laboratory (HEDL), Environmental Protection Manual MG-99, operated by WHC, Richland, Washington.

McCarthy, M. J., 1989a, Westinghouse Hanford Company Effluent Report for 300, 400, and 1100 Area Operations for Calendar Year 1988, WHCEP-0267, Westinghouse Hanford Company, Richland, Washington.

McCarthy, M. J., 1989b, Westinghouse Hanford Company Effluent Report for 300, 400, and 1100 Area Operations for Calendar Year 1987, WHCSP-0385, Westinghouse Hanford Company, Richland, Washington.

McCarthy, M. J., 1989c, Westinghouse Hanford Company Effluent Report for 300, 400, and 1100 Area for Calendar Year 1989, WHC-EP-0267, Rev. 1, Westinghouse Hanford Company, Richland, Washington.

McCarthy, M.J., 1992, Past Practices Technical Characterization Study 300 Area - Hanford Site, WHC-MR-0388, Westinghouse Hanford Company, Richland, Washington.

PNL, 1987, Ground-Water Monitoring Compliance Projects for Hanford Site Facilities: Progress Report for the Period January 1 to March 31, 1987 , Volumes 1, 2, and 3, PNL-6476, Pacific Northwest Laboratory, Richland, Washington.

PNL, 1989, Procedures for Ground-Water Investigations, PNL-6894, Pacific Northwest Laboratories, Richland, Washington. 
Schalla, R., R. L. Aaberg, D. J. Bates, J. V. M. Carlile, M. D. Freshley, T. L. Liikala, P. J. Mitchell, K. B. Olsen, J. T. Rieger, 1988a, Revised Ground-Water Monitoring Compliance Plan for the 300 Area Process Trenches, PNL-6671, Pacific Northwest Laboratory, Richland, Washington.

Schalla, R., R. L. Aaberg, S. P. Airhart, D. J. Bates, J. V. M. Carlile, C. S. Cline, D. I. Dennison, M. D. Freshley, P. R. Heller, E. J. Jensen, K. B. Olren, R. G. Parkhurst, J. T. Rieger, R. W. Wallace, and E. J. Westergard, 1988b, Interim Characterization Report for the 300 Area Process Trenches, PNL-6716, Pacific Northwest Laboratory, Richland, Washington.

Stordeur, R. T., 1992, Hanford 300 Area Process Wastewater Characterization Data Report, WHC-SD-L045H-DP-001, Westinghouse Hanford Company, Richland, Washington.

Swanson, L. C., G. G. Kelty, K. A. Lindsey, K. R. Simpson, R. K. Price and S. D. Consort, 1992, Phase I Hydrogeologic Summary of the 300-FF-T Operable Unit, 300 Area, WHC-SD-EN-TI-052, Westinghouse Hanford Company, Richland, Washington.

WHC, 1987, Westinghouse Hanford Company Effluent Report for 300 and 400 Area Operations for Calendar Year 1987, WHC-SP-0385, Westinghouse Hanford Company, Richland, Washington.

WHC, 1988a, Westinghouse Hanford Company Effluent Report for 300, 400, and 1100 Area for Calendar Year 1988, WHC-EP-0267, Westinghouse Hanford Company, Richland, Washington.

WHC, 1988b, 300 Area Process Trenches - Interim Status Closure/PostClosure Plan, Rev. 1, First Draft, Internal RCRA Closures Report, Westinghouse Hanford Company, Richland, Washington.

WHC, 1989, Environmental Investigations and Site Characterization Manual, WHC-CM-7-7, Westinghouse Hanford Company, Richland, Washington.

WHC, 1990a, 300 Area Process Wastewater Stream-Specific Report, WHC-EP-0342, Addendum 1, Westinghouse Hanford Company, Richland, Washington.

WHC, 1990b, Environmental Releases for Calendar Year 1990, WHC-EP-527, Westinghouse Hanford Company, Richland, Washington.

WHC, 1991a, Characterization and Use of Soil and Groundwater Background for the Hanford Site, WHC-MR-0246, Westinghouse Hanford Company, Richland, Washington.

WHC, 1991b, Environmental Releases for Calendar Year 1991, WHC-EP-527, Rev. 1, Westinghouse Hanford Company, Richland, Washington. 
WHC, 1992a, Quality Assurance Project Plan for RCRA Groundwater Monitoring Activities, WHC-SD-EN-QAPP-001, Rev. 1, Westinghouse Hanford Company, Richiand, Washington.

WHC, 1992b, 316-5 Process Trenches Expedited Response Action Sampling Plan, WHC-SD-EN-AP-055, Rev. 1, Westinghouse Hanford Company, Richiand, Washington.

WHC, 1992C, Environmental Releases for Calendar Year 1992, WHC-EP-527, Rev. 2, Westinghouse Hanford Company, Richland, Washington.

WHC, 1992d, 300 Area Process Sewer System and Sanitation Waste System Piping Configuration - Verification Program Results, WHC-SD-GEN-RPT20001, Rev. 0, Westinghouse Hanford Company, Richland, Washington.

WHC, 1992e, Past Practice Technical Characterization Study - 300 Area Hanford Site, WHC-MR-0388, Westinghouse Hanford Company, Richland, Washington.

WHC, 1993, 300 Area Process Sewer Sampling Analysis Plan, WHC-SD-L-045HPLN-001, Rev. 0, Westinghouse Hanford Company, Richland, Washington.

WHC, 1994a, Soil Physical Separations Treatability Safety Assessment for 100 and 300 Areas, WHC-SD-EN-SAD-005, Rev. 2, Westinghouse Hanford Company, Richland, Washington.

WHC, 1994b, 300-FF-1 OU Operable Unit Physical Separation of Soils Pilot Plant Study, WHC-SD-EN-TI-277, Westinghouse Hanford Company, Richland, Washington.

WHC-CM-7-5, Environmental Compliance, Westinghouse Hanford Company, Richland, Washington.

Young, 1990, PNL-7241, Data Compilation Task Report for the Source Investigation of the $300-F F-1$ OU Phase I Remedial Investigation, Pacific Northwest Laboratory, Richland, Washington.

Young \& Fruchter, 1991, EMO-1026, Addendum to Data Compilation Task Report for the Source Investigation of the 300-FF-1 oU Phase I Remedial Investigation, Pacific Northwest Laboratory, Richland, Washington.

\subsection{CODE OF FEDERAL REGULATIONS AND FEDERAL REGISTER}

29 CFR 1920.120, "Hazardous Waste Operations and Emergency Response", Title 29, Code of Federal Regulations, as amended.

40 CFR 141, "National Primary Drinking Water Regulations," Code of Federal Regulations, as amended. 
40 CFR 261, "Identification and Listing of Hazardous Waste," Code of Federal Regulations, as amended.

40 CFR 265, "Protection of Environment," Title 40, Code of Federal Regulations, Part 265, as amended, U.S. Environmental Protection Agency, Washington, D.C.

40 CFR 270, "EPA Administered Permit Programs: The Hazardous Waste Permit Program, "Title 40, Code of Federal Regulations, Part 270, as amended, U.S. Environmental Protection Agency, Washington, D.C.

51 FR 7722, 1986, "Hazardous Waste Management System, Supplement to Preamble and Final Codification Rule, "Federal Register, Vol. 51, p. 7722 , (March 5).

\subsection{FEDERAL AND STATE ACTS}

Comprehensive Environmental Response, Compensation, and Liability Act of 1980, 42 U.S.C. 9601 et seq.

Resource Conservation and Recovery Act of 1976, 42 U.S.C. 6901 et seq.

\subsection{WASHINGTON ADMINISTRATIVE CODE}

WAC 173-160, "Minimum Standards for Construction and Maintenance of Wells," Washington Administrative Code, as amended.

WAC 173-200, "Water Quality Standards of the State of Washington," Washington Administrative Code, as amended.

WAC 173-201, "Water Quality Standards for Surface Waters of the State of Washington," Washington Administrative Code, as amended.

WAC 173-216, "State Waste Discharge Permit Program," Washington Administrative Code, as amended.

WAC 173-303, 1990, "Dangerous Waste Regulations, "Washington Administrative Code, as amended.

WAC 173-340, 1990, "The Model Toxics Control Act Cleanup Regulations," Washington Administrative Code, as amended. 
DOE/RL-93-73, Rev. 0

$08 / 15 / 94$

\subsection{THE U.S. DEPARTMENT OF ENERGY ORDERS}

5820.2A, Radioactive Waste Management. 


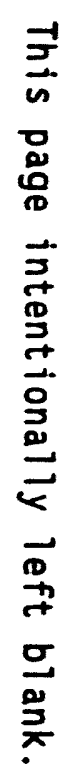

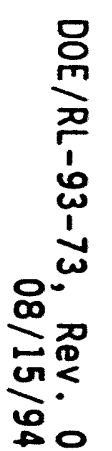




\section{APPENDICES}

2A PHOTOGRAPHS

5A GROUNDWATER REFERENCES

$7 A$ SAMPLING AND ANALYSIS PLAN

7B SAMPLING DATA AND EVALUATION PACKAGE FOR THE 300 APT

7C TRAINING COURSE DESCRIPTIONS

70 SUMMARY OF PRE-AND POST-ERA SAMPLING DATA 
DOE/RL-93-73, Rev. 0

$08 / 15 / 94$

1
2
3
4
5
6.

This page intentionally left blank. 
DOE/RL-93-73, Rev. 0

$08 / 15 / 94$

APPENDIX $2 \mathrm{~A}$

PHOTOGRAPHS

APP $2 A-i$ 
DOE/RL-93-73, Rev. 0

$08 / 15 / 94$

This page intentionally left blank. 
DOE/RL-93-73, Rev. 0

$08 / 15 / 94$

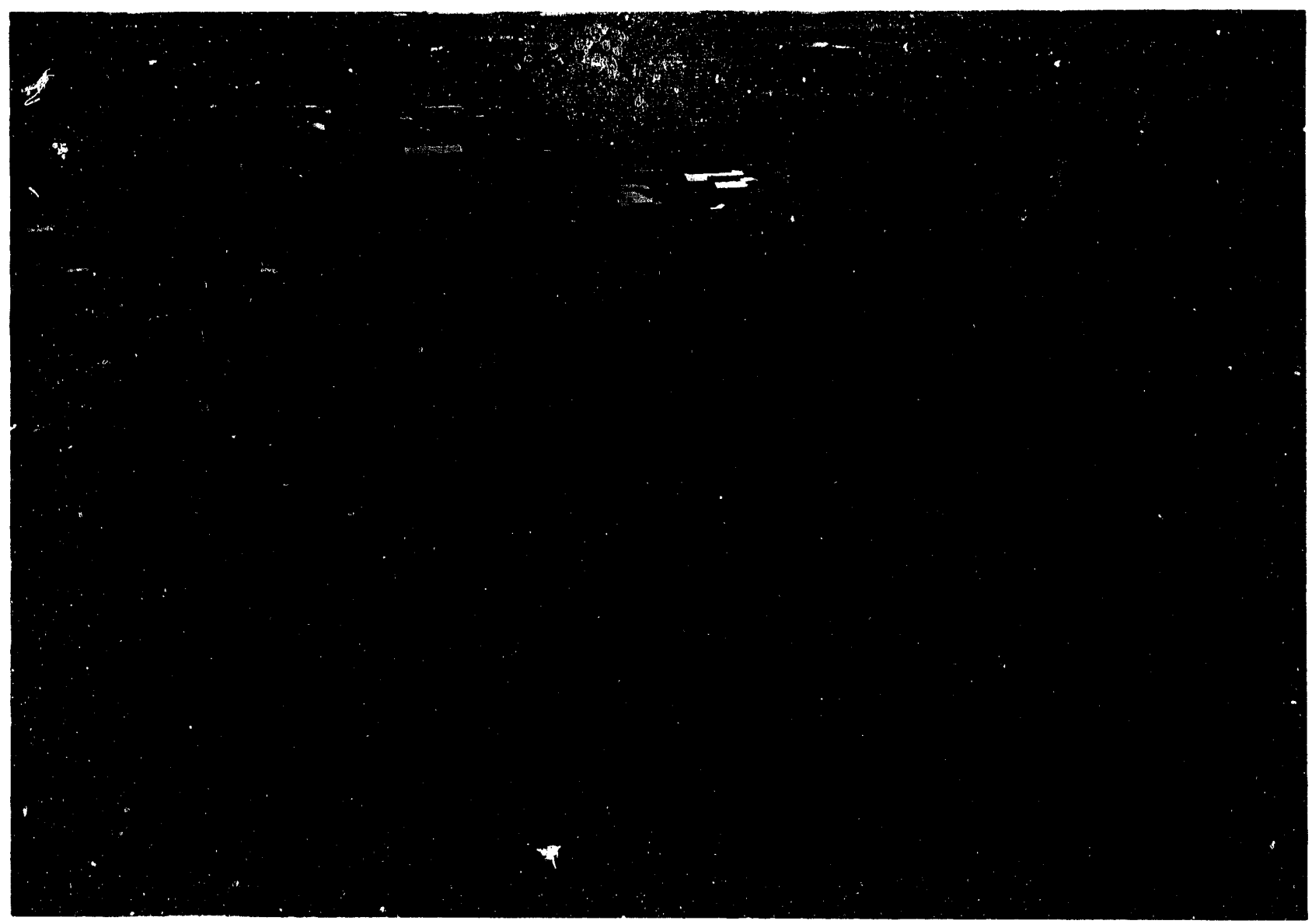

8703018-54CN (PHOTO TAKEN 1987)

2A-1. 300 Area Process Trenches Pre-Expedited Response Action (Facing South). 


$$
\text { DOE/RL-93-73, Rev. } 00
$$

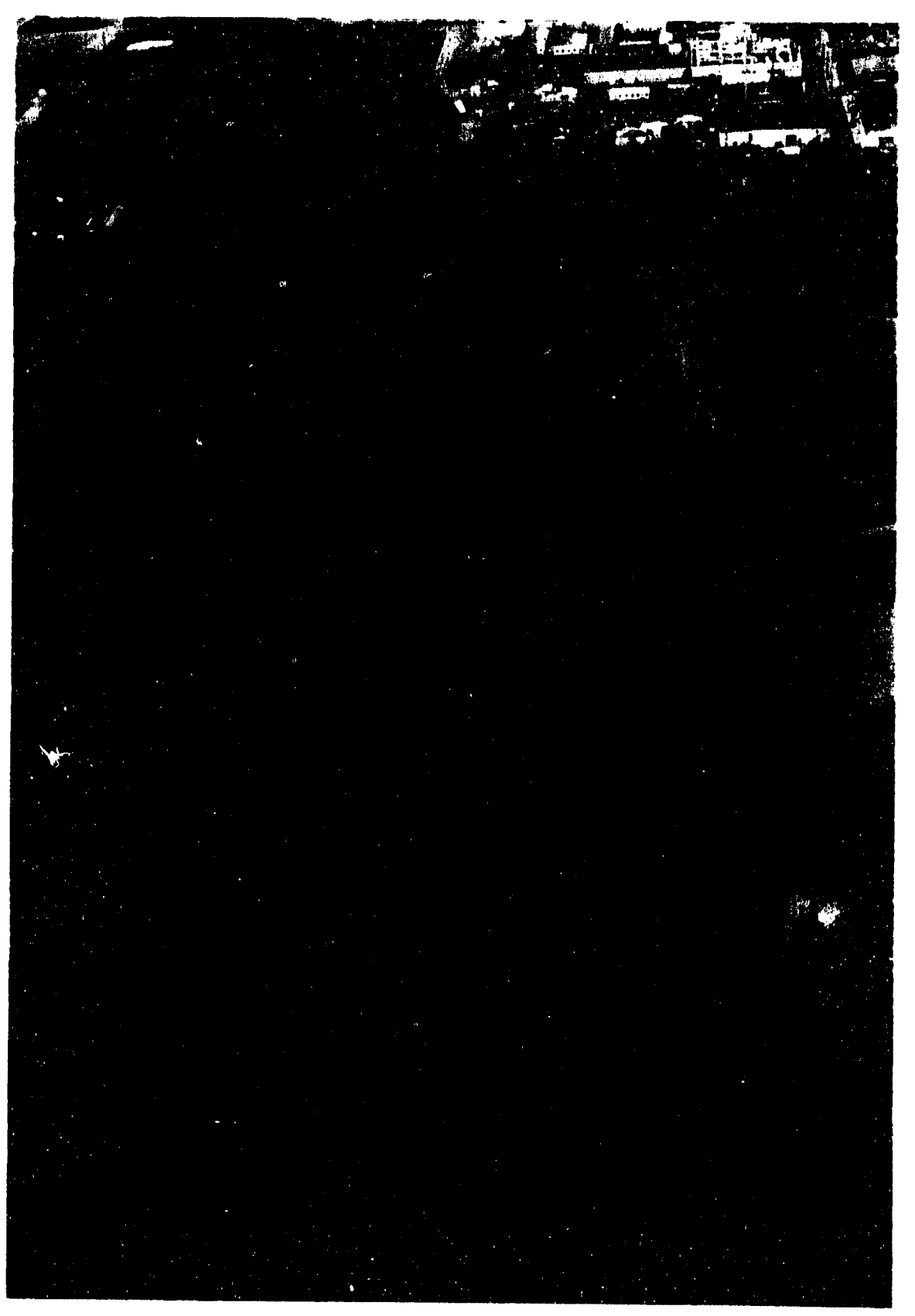

\section{A-2. 300 Area Process Trenches Post-Expedited Response Action (Facing South).}




\section{APPENDIX 5A \\ GROUNDWATER REFERENCES}




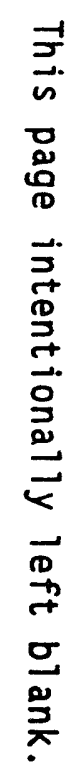

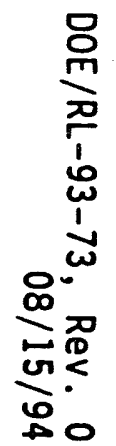




\section{APPENDIX 5A \\ GROUNDWATER REFERENCES}

\section{PERIOD 1988}

PNL, 1988, Ground-Water Monitoring Compliance Projects for Hanford Site Facilities: Progress Report for the Period January 1 to March 31, 1988, PNL-6581, Pacific Northwest laboratory, Richland, Washington.

PNL, 1988, Ground-Water Monitoring Compliance Projects for Hanford Site Facilities: Progress Report for the Period April 1 to June 30, 1988, PNL-6675, Pacific Northwest Laboratory, Richland, Washington.

Fruland, R.M., D.J. Bates, and R.E. Lundgren, 1989, Resource Conservation and Recovery Act Ground-Water Monitoring Projects for Hanford Facilities: Progress Report for the Period July 1 to September 30, 1988: PNL-6789, Pacific Northwest Laboratory, Richland Washington.

Fruland, R.M., D.J. Bates, and R.E. Lundgren, 1989, Resource Conservation and. Recovery Act Ground-Water Monitoring Projects for Hanford Facilities: Progress Report for the Period October 1 to December 31, 1988: PNL-6844, Pacific Northwest Laboratory, Richland Washington.

Fruland, R.M., and R.E. Lundgren, eds., 1989, RCRA Ground-Water Monitoring Projects for Hanford Facilities: Annual Progress Report for 1988, PNL-6852, Pacific Northwest Laboratory, Richland, Washington.

\section{PERIOD 1989}

Smith, R.M., D.J. Bates, and R.E. Lundgren, 1989, Resource Conservation and Recovery Act Ground-Water Monitoring Projects for Hanford Facilities: Progress Report for the Period January 1 to March 31, 1989: PNL-6957, Pacific Northwest Laboratory, Richland Washington.

Smith, R.M., D.J. Bates, and R.E. Lundgren, 1989, Resource Conservation and Recovery Act Ground-Water Monitoring Projects for Hanford Facilities: Progress Report for the Period April 1 to June 30, 1989: PNL-7134, Pacific Northwest Laboratory, Richland Washington.

Smith, R.M., D.J. Bates, and R.E. Lundgren, 1989, Resource Conservation and Recovery Act Ground-Water Monitoring Projects for Hanford Facilities: Progress Report for the Period July 1 to September 30, 1989: PNL-7222, Pacific Northwest Laboratory, Richland Washington.

Smith, R.M., D.J. Bates, and R.E. Lundgren, 1990, Resource Conservation and Recovery Act Ground-Water Monitoring Projects for Hanford Facilities: Progress Report for the Period October 1 to December 31, 1989: PNL-7306, Pacific Northwest Laboratory, Richland Washington. 
Smith, R.M. and W.R. Gorst, eds., 1990, RCRA Ground-Water Monitoring

Projects for Hanford Facilities: Annual Progress Report for 1989,

PNL-6852, Pacific Northwest Laboratory, Richland, Washington.

\section{PERIOD 1990}

WHC, 1990, Quarterly Report of Resource Conservation and Recovery Act Groundwater Monitoring Data for Period January 1, 1990 Through March 31, 1990, letter from R.E. Lerch to R.D. Izatt, dated May 25, 1990, \#9053781, Westinghouse Hanford Company, Richland, Washington.

DOE, 1990, Quarterly Report of RCRA Groundwater Monitoring Data for Period April 1, 1990 through June 30, 1990, DOE/RL-90-36, U.S. Department of Energy, Richland, Washington.

DOE, 1990, Quarterly Report of RCRA Groundwater Monitoring Data for Period July 1, 1990 through September 30, 1990, DOE/RL-90-46, U.S. Department of Energy, Richland, Washington.

DOE, 1991, Quarterly Report of RCRA Groundwater Monitoring Data for Period October 1, 1990 through December 31, 1990, DOE/RL-91-04, U.S. Department of Energy, Richland, Washington.

DOE, 1991, Annual Report for RCRA Groundwater Monitoring Projects at Hanford Site Facilities for 1990, DOE/RL-91-03, U.S. Department of Energy, Richland, Washington.

\section{PERIOD 1991}

DOE, 1991, Quarterly Report of RCRA Groundwater Monitoring Data for Period January 1, 1991 through March 31, 1991, DOE/RL-91-26, U.S. Department of Energy, Richland Washington.

DOE, 1991, Quarterly Report of RCRA Groundwater Monitoring Data for Period April 1, 1991 through June 30, 1991, DOE/RL-91-47, U.S. Department of Energy, Richland, Washington.

DOE, 1991, Quarterly Report of RCRA Groundwater Monitoring Data for Period July 1, 1991 through September 30, 1991, DOE/RL-91-57, U.S. Department of Energy, Richland, Washington.

DOE, 1992, Quarterly Report of RCRA Groundwater Monitoring Data for Period October 1, 1991 through December 31, 1991, DOE/RL-92-26, U.S. Department of Energy, Richland, Washington.

DOE, 1992, Annual Report for RCRA Groundwater Monitoring Projects at Hanford Site Facilities for 1991, DOE/RL-92-03, U.S. Department of Energy, Richland, Washington. 


\section{PERIOD 1992}

DOE, 1992, Quarterly Report of RCRA Groundwater Monitoring Data for Period January 1, 1992 through March 31, 1992, DOE/RL-92-26-1, U.S. Department of Energy, Richland Washington.

DOE, 1992, Quarterly Report of RCRA Groundwater Monitoring Data for Period April 1, 1992 through June 30, 1992, DOE/RL-92-26-2, U.S.

Department of Energy, Richiand, Washington.

DOE, 1992, Quarterly Report of RCRA Groundwater Monitoring Data for Period July 1, 1992 through September 30, 1992, DOE/RL-92-26-3, U.S. Department of Energy, Richland, Washington.

DOE, 1993, Quarterly Report of RCRA Groundwater Monitoring Data for Period October 1, 1992 through December 31, 1992, DOE/RL-92-26-4, U.S. Department of Energy, Richland, Washington.

DOE, 1993, Annual Report for RCRA Groundwater Monitoring Projects at Hanford Site Facilities for 1992, D0E/RL-93-09, U.S. Department of Energy, Richl and, Washington.

\section{PERIOD 1993}

DOE, 1993, Quarterly Report of RCRA Groundwater Monitoring Data for Period January 1, 1993 through March 31, 1993, DOE/RL-93-56-1, U.S. Department of Energy, Richland Washington.

DOE, 1993, Annual Report for RCRA Groundwater Monitoring Projects at Hanford Site Facilities for 1993, DOE/RL-93-88, U.S. Department of Energy, Richland, Washington. 
DOE/RL-93-73, Rev. 0 $08 / 15 / 94$

This page intentionally left blank. 
DOE/RL-93-73, Rev. 0

$08 / 15 / 94$

APPENDIX 7A

SAMPLING AND ANALYSIS PLAN

[RESERVED] 
DOE/RL-93-73, Rev. 0

$08 / 15 / 94$

This page intentionally left blank. 


\section{APPENDIX 7B}

SAMPLING DATA AND EVALUATION PACKAGE FOR THE 300 APT

[RESERVED] 
DOE/RL-93-73, Rev. 0

$08 / 15 / 94$

This page intentionally left blank. 
DOE/RL-93-73, Rev. 0

$08 / 15 / 94$

\section{APPENDIX 7C}

\section{TRAINING COURSE DESCRIPTIONS}

This appendix contains a training matrix and brief course descriptions. 
DOE/RL-93-73, Rev. 0

$08 / 15 / 94$

This page intentionally left blank. 


\begin{tabular}{|c|c|c|}
\hline \multicolumn{3}{|c|}{ ENVIRONMENTAL AND HAZARDOUS MATERIAL SAFETY TRAINING } \\
\hline & Course name & Description \\
\hline 1. & $\begin{array}{l}\text { Hazard Communication and } \\
\text { Waste Orientation }\end{array}$ & $\begin{array}{l}\text { Course provides an overview of the } \\
\text { federal and applicable hazard } \\
\text { communication programs and hazardous } \\
\text { and/or dangerous waste disposal programs. }\end{array}$ \\
\hline 2. & $\begin{array}{l}\text { Generator Hazards Safety } \\
\text { Training }\end{array}$ & $\begin{array}{l}\text { Course provides the hazardous and/or } \\
\text { dangerous material/waste worker with the } \\
\text { fundamentals for use and disposal of } \\
\text { hazardous and/or dangerous materials. }\end{array}$ \\
\hline 3. & $\begin{array}{l}\text { Hazardous Materials/Waste } \\
\text { Job-Specific Training }\end{array}$ & $\begin{array}{l}\text { Course provides specific information on } \\
\text { hazardous and/or dangerous chemicals and } \\
\text { waste management at the employees' } \\
\text { TSD unit. }\end{array}$ \\
\hline 4. & $\begin{array}{l}\text { Initial Radiation Worker } \\
\text { Training }\end{array}$ & $\begin{array}{l}\text { Course provides radiation workers with } \\
\text { the fundamentals of radiation protection } \\
\text { and the proper procedures for maintaining } \\
\text { exposures ALARA. }\end{array}$ \\
\hline 5. & Waste Site Basics & $\begin{array}{l}\text { Course provides required information for } \\
\text { the safe operation of hazardous and/or } \\
\text { dangerous waste TSD units regulated under } \\
40 \text { CFR } 264 \text { and } 265 \text { pursuant to RCRA and } \\
\text { WAC } 173-303 \text {. }\end{array}$ \\
\hline 6. & $\begin{array}{l}\text { Scott 'SKA-PAK'1 } \\
\text { Training-SKA }\end{array}$ & $\begin{array}{l}\text { Course instructs employees in the proper } \\
\text { use of the Scott 'SKA-PAK' for entry, } \\
\text { exit, or work in conditions 'immediately } \\
\text { dangerous to life and health' and } \\
\text { instructs employees to recognize and } \\
\text { handle emergencies. }\end{array}$ \\
\hline 7. & $\begin{array}{l}\text { Cardiopulmonary } \\
\text { Resuscitation }\end{array}$ & $\begin{array}{l}\text { Course of the American Heart Association } \\
\text { that provides certification in } \\
\text { cardiopulmonary resuscitation for the } \\
\text { single rescuer (Heartsaver Course). }\end{array}$ \\
\hline
\end{tabular}

'Scott SKA-PAK is a trademark of Figgie International, Incorporated. 


\begin{tabular}{|c|c|c|}
\hline & Course name & Description \\
\hline 8. & Fire Extinguisher Safety & $\begin{array}{l}\text { Course provides videocassette } \\
\text { presentation that covers types of } \\
\text { portable fire extinguishers and the } \\
\text { proper usage for each. }\end{array}$ \\
\hline 9. & Waste Site--Advanced & $\begin{array}{l}\text { Course provides environmental safety } \\
\text { information for RCRA and/or CERCLA } \\
\text { operations and sites. Topics include } \\
\text { regulations and acronyms, occupational } \\
\text { health and safety, chemical hazard } \\
\text { information, toxicology, personal } \\
\text { protective equipment and respirators, } \\
\text { site safety, decontamination, and } \\
\text { chemical monitoring instrumentation. }\end{array}$ \\
\hline 10. & $\begin{array}{l}\text { Waste Site Field } \\
\text { Experience }\end{array}$ & $\begin{array}{l}\text { Course is a } 3 \text {-day field experience under } \\
\text { the direct supervision of a trained, } \\
\text { experienced supervisor. }\end{array}$ \\
\hline 11. & $\begin{array}{l}\text { Hazardous Waste Shipment } \\
\text { Certification }\end{array}$ & $\begin{array}{l}\text { Course provides an in depth look at } \\
\text { federal, state, and Hanford Site } \\
\text { requirements for nonradioactive hazardous } \\
\text { and/or dangerous waste management and } \\
\text { transportation. }\end{array}$ \\
\hline 12. & $\begin{array}{l}\text { Certification of } \\
\text { Hazardous Material } \\
\text { Shipments }\end{array}$ & $\begin{array}{l}\text { Course provides training in dangerous } \\
\text { material regulation of the } \\
\text { U.S. Department of Transportation, as } \\
\text { required by law, to those who certify the } \\
\text { compliance of Hanford Site hazardous } \\
\text { and/or dangerous material shipments. The } \\
\text { main focus is on the proper preparation } \\
\text { and release of radioactive material } \\
\text { shipments. }\end{array}$ \\
\hline 13. & $\begin{array}{l}\text { Hazardous Waste Site } \\
\text { Supervisor/Manager }\end{array}$ & $\begin{array}{l}\text { Course provides specialized training to } \\
\text { operations and site management in the } \\
\text { following programs: safety and health, } \\
\text { employee training, personal protective } \\
\text { equipment, spill containment, and health } \\
\text { hazard monitoring procedures and } \\
\text { techniques. }\end{array}$ \\
\hline
\end{tabular}


DOE/RL-93-73, Rev. 0 $08 / 15 / 94$

\section{APPENDIX 7D}

SUMMARY OF PRE- AND POST-ERA SAMPLING DATA 
Do
궁
‥
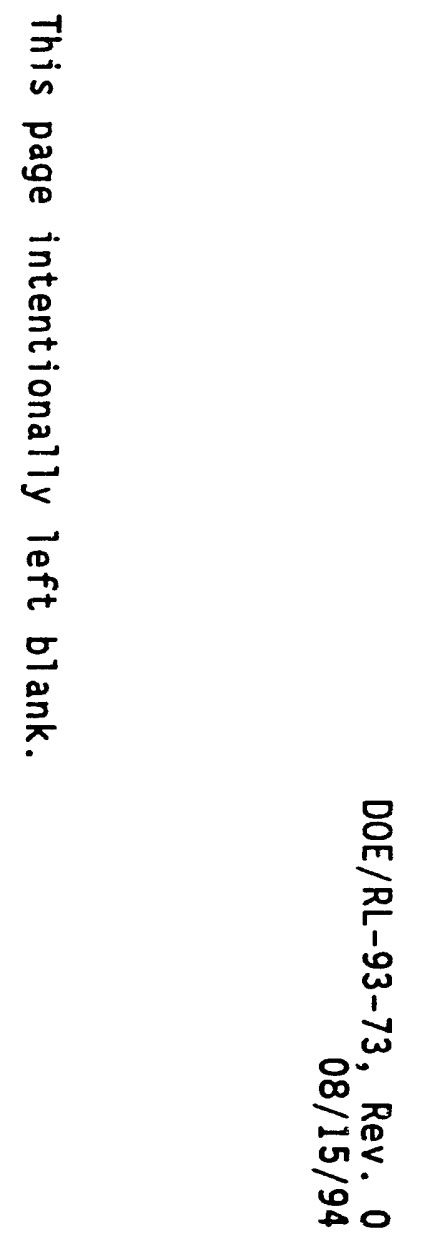
Location 316-2, 399-1-22

\begin{tabular}{|c|c|c|c|c|c|}
\hline \multirow[t]{2}{*}{ Paraseter } & \multirow{2}{*}{$\begin{array}{l}\text { Sempl } \\
\text { Depth }\end{array}$} & \multicolumn{2}{|l|}{$\begin{array}{r}80144177 \\
30.00\end{array}$} & \multicolumn{2}{|l|}{$\begin{array}{r}0014143 \\
32.00\end{array}$} \\
\hline & & Result & $a$ & Result & a \\
\hline 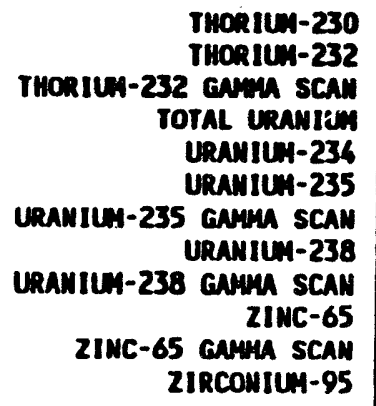 & 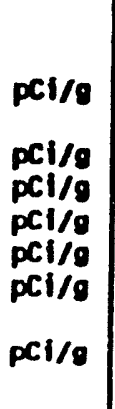 & $\begin{array}{c}W / R \\
N / R \\
0.931 \\
W / R \\
2.700 \\
0.240 \\
M / R \\
2.400 \\
N / R \\
N / R \\
0.168 \\
N / R\end{array}$ & $\begin{array}{l}d \\
d \\
d\end{array}$ & $\begin{array}{c}W / R \\
W / R \\
0.635 \\
W / R \\
1.800 \\
0.100 \\
W / R \\
1.500 \\
W / R \\
N / R \\
0.173 \\
M / R\end{array}$ & $\begin{array}{l}J \\
J \\
J\end{array}$ \\
\hline
\end{tabular}

ज̃ 
Location 316-5E PRE

\begin{tabular}{|c|c|c|c|c|c|c|c|c|c|c|c|c|c|}
\hline \multirow[t]{2}{*}{ Paremeter } & \multirow{2}{*}{\begin{tabular}{|l|}
$\begin{array}{l}\text { Sempip } \\
\text { Depth }\end{array}$ \\
Unite
\end{tabular}} & \multicolumn{2}{|c|}{$\begin{array}{r}801034 \\
0.50\end{array}$} & \multicolumn{2}{|c|}{$\begin{array}{r}001037 \\
0.50\end{array}$} & \multicolumn{2}{|c|}{$\begin{array}{r}001038 \\
0.50\end{array}$} & \multicolumn{2}{|c|}{$\begin{array}{r}001040 \\
0.50\end{array}$} & \multicolumn{2}{|c|}{$\begin{array}{r}001043 \\
0.50\end{array}$} & \multicolumn{2}{|c|}{$\begin{array}{r}001046 \\
0.50\end{array}$} \\
\hline & & Result & 0 & Reault & 0 & Result & a & Result & $a$ & reault & a & Result & a \\
\hline 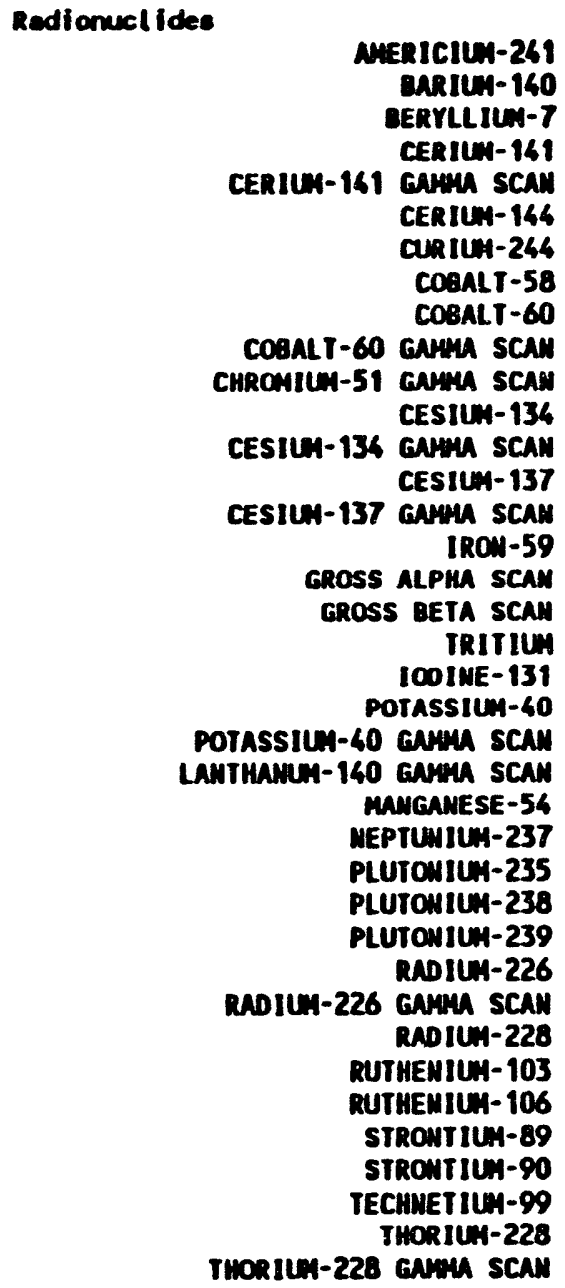 & 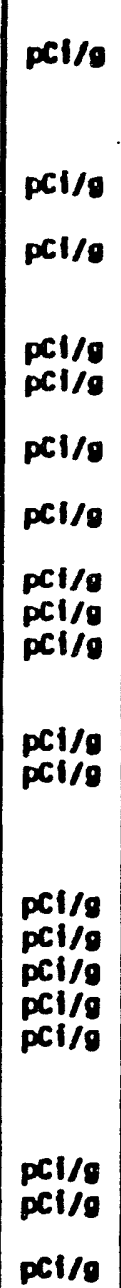 & 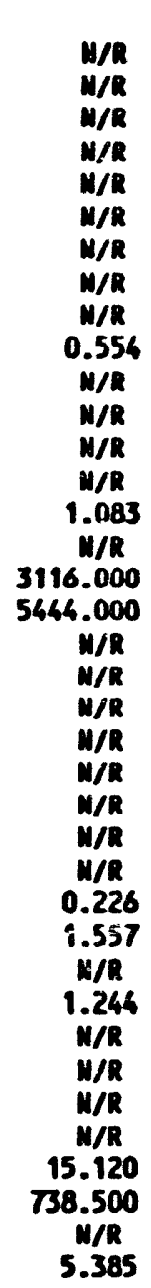 & $\begin{array}{l}\text { d } \\
\text { d }\end{array}$ & 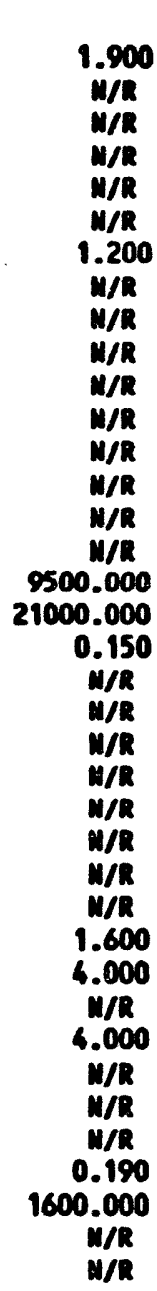 & $\begin{array}{r}R \\
R \\
R \\
\mathbf{R} \\
\mathbf{U}\end{array}$ & 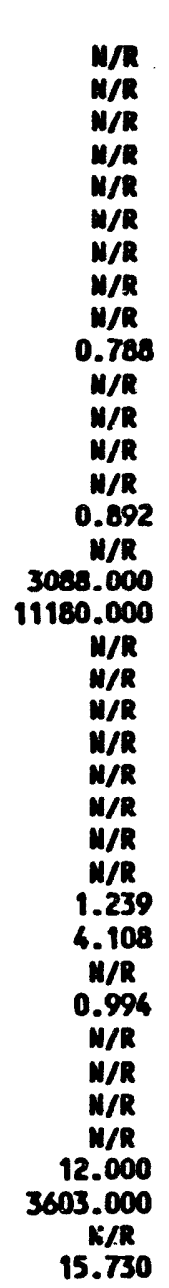 & $\begin{array}{l} \\
\\
\\
\mathbf{R} \\
\mathbf{R} \\
\mathbf{J}\end{array}$ & 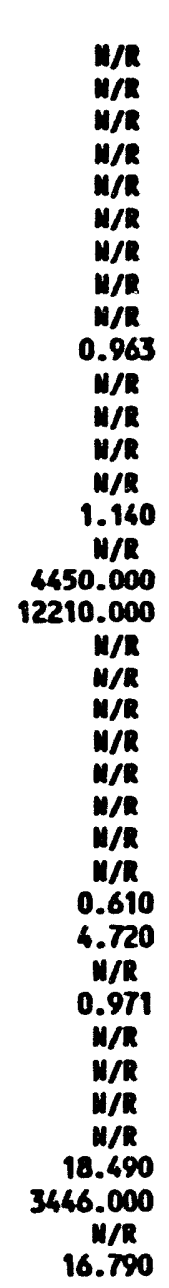 & $\begin{array}{l}\text { J } \\
\text { R } \\
\text { J }\end{array}$ & 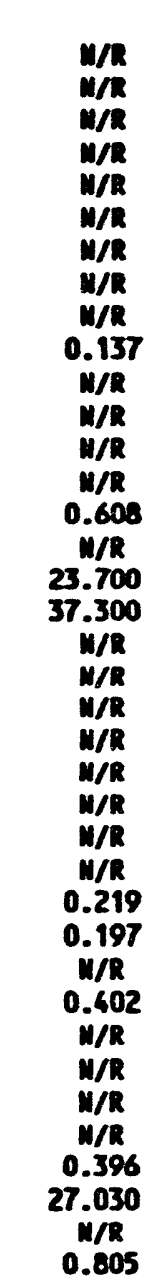 & $\begin{array}{l}2 \\
R \\
J\end{array}$ & 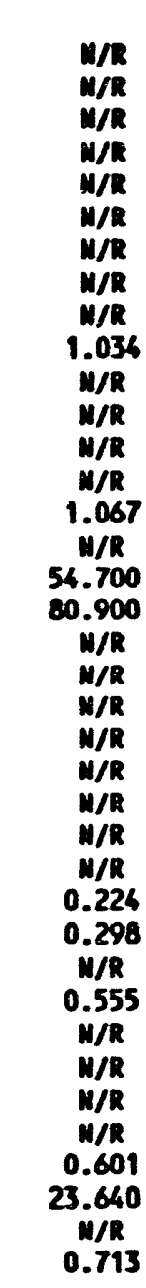 & R \\
\hline
\end{tabular}


Location 316-5E PRE

\begin{tabular}{|c|c|c|c|c|c|c|c|c|c|c|c|c|c|}
\hline \multirow[t]{2}{*}{ Parameter } & \multirow{2}{*}{$\begin{array}{l}\text { Sempl } \\
\text { Depth }\end{array}$} & \multicolumn{2}{|c|}{$\begin{array}{r}801036 \\
0.50\end{array}$} & \multicolumn{2}{|c|}{$\begin{array}{r}001037 \\
0.50\end{array}$} & \multicolumn{2}{|c|}{$\begin{array}{r}001038 \\
0.50\end{array}$} & \multicolumn{2}{|c|}{$\begin{array}{r}201040 \\
0.50\end{array}$} & \multicolumn{2}{|c|}{$\begin{array}{r}001043 \\
0.50\end{array}$} & \multicolumn{2}{|c|}{$\begin{array}{r}001046 \\
0.50\end{array}$} \\
\hline & & Result & a & Result & $a$ & Reault & a & Result & e & Reault & 9 & Reault & a \\
\hline 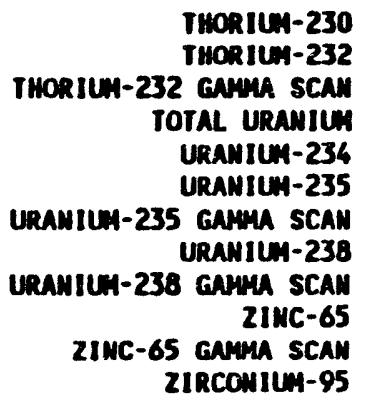 & $\begin{array}{l}\mathrm{pCl} / \mathrm{g} \\
\mathrm{pCi} / \mathrm{g} \\
\mathrm{pCl} / \mathrm{g} \\
\mathrm{pCi} / \mathrm{g} \\
\mathrm{pCl} / \mathrm{g} \\
\mathrm{pCi} / \mathrm{g} \\
\mathrm{pCi} / \mathrm{g} \\
\mathrm{pCl} / \mathrm{g} \\
\mathrm{pCi} / \mathrm{g} \\
\mathrm{pCl} / \mathrm{g}\end{array}$ & $\begin{array}{c}W / R \\
N / R \\
1.429 \\
6718.000 \\
3565.000 \\
318.600 \\
N / R \\
2917.000 \\
N / R \\
N / R \\
N / R \\
N / R\end{array}$ & $\begin{array}{l}J \\
J \\
R \\
R \\
R\end{array}$ & $\begin{array}{c}16.000 \\
0.460 \\
W / R \\
W 1000.000 \\
72.000 \\
7.900 \\
W / R \\
64.000 \\
W / R \\
W / R \\
W / R \\
W / R\end{array}$ & $\begin{array}{l}R \\
R \\
R \\
R \\
R \\
R \\
R\end{array}$ & $\begin{array}{c}M / R \\
W / R \\
1.7 / 51 \\
15535.000 \\
8790.000 \\
1556.000 \\
638.400 \\
6032.000 \\
9163.000 \\
W / R \\
W / R \\
W / R\end{array}$ & $\begin{array}{l}j \\
d \\
R \\
R\end{array}$ & $\begin{array}{c}M / R \\
M / R \\
1.656 \\
20034.000 \\
9747.000 \\
379.200 \\
W / R \\
9132.000 \\
W / R \\
N / R \\
N / R \\
N / R\end{array}$ & $\begin{array}{l}j \\
j \\
0 \\
0\end{array}$ & $\begin{array}{c}W / R \\
W / R \\
0.566 \\
143.600 \\
105.700 \\
10.110 \\
W / R \\
76.500 \\
W / R \\
W / R \\
N / R \\
N / R\end{array}$ & $\begin{array}{l}\mathbf{J} \\
\mathbf{j} \\
\mathbf{R} \\
\mathbf{R} \\
\mathbf{R}\end{array}$ & $\begin{array}{c}W / R \\
W / R \\
0.674 \\
144.600 \\
71.510 \\
4.200 \\
W / R \\
68.980 \\
W / R \\
W / R \\
N / R \\
W / R\end{array}$ & $\begin{array}{l}d \\
j \\
R \\
R\end{array}$ \\
\hline
\end{tabular}

$\infty$
$\vdots$
$y$ 
Location 316-5E PRE

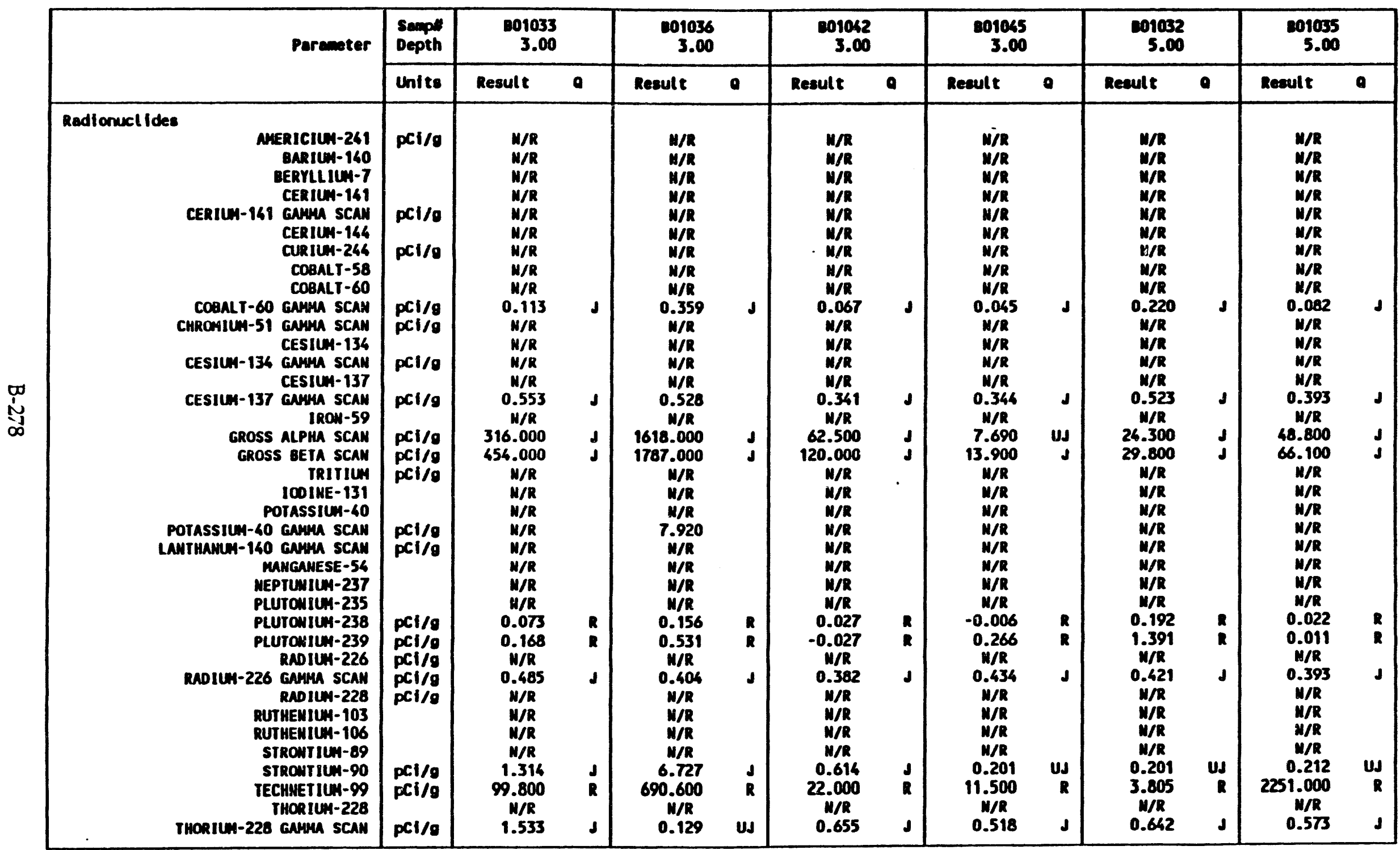


Location 316-5E PRE

\begin{tabular}{|c|c|c|c|c|c|c|c|c|c|c|c|c|c|}
\hline \multirow[t]{2}{*}{ Parameter } & \multirow{2}{*}{$\begin{array}{l}\text { Sempl } \\
\text { Depth }\end{array}$} & \multicolumn{2}{|l|}{$\begin{array}{r}001033 \\
3.00\end{array}$} & \multicolumn{2}{|l|}{$\begin{array}{r}001036 \\
3.00\end{array}$} & \multicolumn{2}{|l|}{$\begin{array}{r}801062 \\
3.00\end{array}$} & \multicolumn{2}{|l|}{$\begin{array}{r}201045 \\
3.00\end{array}$} & \multicolumn{2}{|l|}{$\begin{array}{r}001032 \\
5.00\end{array}$} & \multicolumn{2}{|c|}{$\begin{array}{r}001035 \\
5.00\end{array}$} \\
\hline & & Result & a & Result & a & Result & a & Result & $\mathbf{a}$ & Reeut & a & Reeult & a \\
\hline 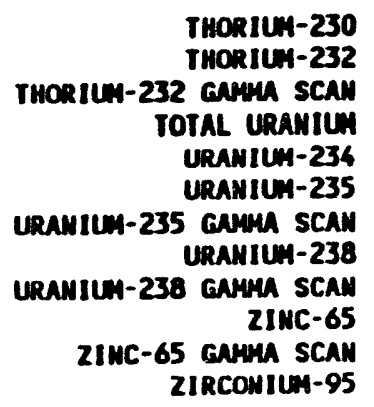 & 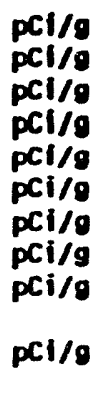 & $\begin{array}{c}M / R \\
M / R \\
0.626 \\
1032.000 \\
502.700 \\
73.880 \\
W / R \\
356.500 \\
W / R \\
W / R \\
W / R \\
W / R\end{array}$ & $\begin{array}{l}\mathbf{J} \\
\mathbf{J} \\
\mathbf{R} \\
\mathbf{R} \\
\mathbf{R}\end{array}$ & $\begin{array}{c}W / R \\
W / R \\
0.828 \\
2132.000 \\
1492.000 \\
138.300 \\
84.660 \\
1072.000 \\
1246.000 \\
W / R \\
W / R \\
W / R\end{array}$ & $\begin{array}{l}J \\
d \\
R \\
R\end{array}$ & $\begin{array}{c}M / R \\
W / R \\
0.651 \\
61.690 \\
42.830 \\
7.391 \\
M / R \\
32.880 \\
M / R \\
M / R \\
M / R \\
M / R\end{array}$ & $\begin{array}{l}\mathbf{J} \\
\mathbf{J} \\
\mathbf{R} \\
\mathbf{R} \\
\mathbf{R}\end{array}$ & $\begin{array}{c}W / R \\
W / R \\
0.518 \\
12.070 \\
5.542 \\
0.679 \\
W / R \\
4.289 \\
W / R \\
W / R \\
W / R \\
W / R\end{array}$ & $\begin{array}{l}J \\
d \\
R \\
R \\
R\end{array}$ & $\begin{array}{c}W / R \\
W / R \\
0.595 \\
27.830 \\
12.110 \\
1.715 \\
W / R \\
9.190 \\
W / R \\
W / R \\
W / R \\
W / R\end{array}$ & $\begin{array}{l}d \\
d \\
1 \\
k\end{array}$ & $\begin{array}{c}W / R \\
W / R \\
0.594 \\
104.200 \\
67.690 \\
9.186 \\
W / R \\
49.830 \\
W / R \\
W / R \\
W / R \\
W / R\end{array}$ & $\begin{array}{l}\mathbf{J} \\
\mathbf{J} \\
\mathbf{R} \\
\mathbf{R}\end{array}$ \\
\hline
\end{tabular}


Location 316-5E PRE

\begin{tabular}{|c|c|c|c|c|c|}
\hline \multirow[t]{2}{*}{ Parmeter } & \multirow{2}{*}{$\begin{array}{l}\text { Samp } \\
\text { Depth }\end{array}$} & \multicolumn{2}{|l|}{$\begin{array}{r}001061 \\
5.00\end{array}$} & \multicolumn{2}{|l|}{$\begin{array}{r}001046 \\
5.00\end{array}$} \\
\hline & & Result & $\mathbf{0}$ & Result & - \\
\hline 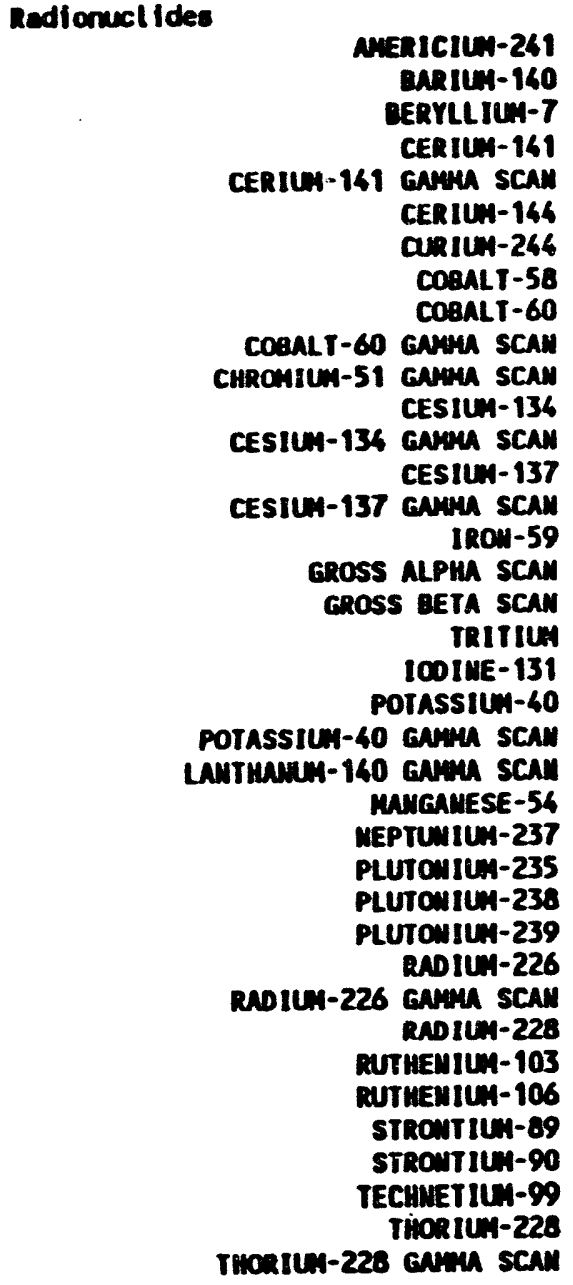 & $\begin{array}{l}\mathrm{pCl} / \mathrm{g} \\
\mathrm{pCl} / \mathrm{g} \\
\mathrm{pCl} / \mathrm{g} \\
\mathrm{pCl} \\
\mathrm{pCl} / \mathrm{g} \\
\mathrm{pCl} \\
\mathrm{pCl} / \mathrm{g} \\
\mathrm{pCl} \\
\mathrm{pCl} / \mathrm{g} \\
\mathrm{pCl} / \mathrm{g}\end{array}$ & 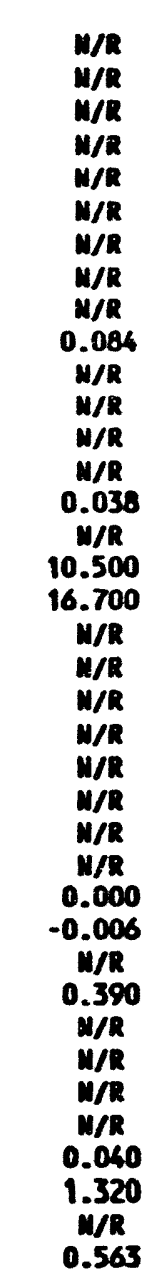 & $\begin{array}{l}d \\
d\end{array}$ & 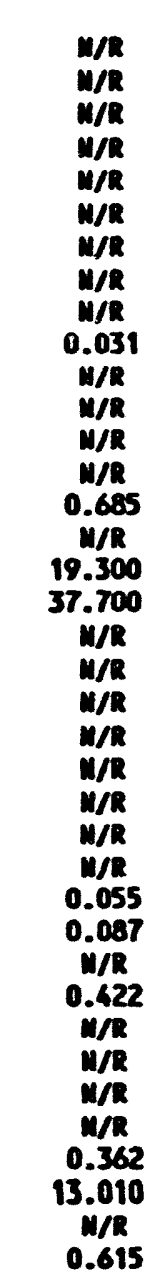 & $\underset{\mathbf{R}}{\mathbf{w}}$ \\
\hline
\end{tabular}


Location 316-5E PRE

\begin{tabular}{|c|c|c|c|c|c|}
\hline \multirow[t]{2}{*}{ Parmeter } & \multirow{2}{*}{$\begin{array}{l}\text { Semply } \\
\text { Depth }\end{array}$} & \multicolumn{2}{|c|}{$\begin{array}{r}001061 \\
5.00\end{array}$} & \multicolumn{2}{|c|}{$\begin{array}{r}201044 \\
5.00\end{array}$} \\
\hline & & Result & a & Result & c \\
\hline 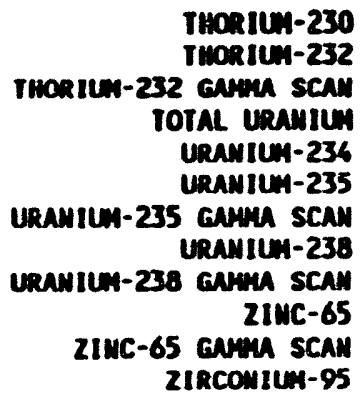 & 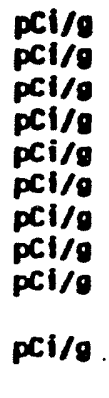 & $\begin{array}{c}W / R \\
W / R \\
0.562 \\
15.890 \\
12.980 \\
2.133 \\
W / R \\
B .642 \\
W / R \\
W / R \\
W / R \\
W / R\end{array}$ & $\begin{array}{l}d \\
d \\
R \\
R \\
R\end{array}$ & $\begin{array}{c}W / 2 \\
m / R \\
0.583 \\
76.690 \\
36.670 \\
2.962 \\
W / R \\
30.160 \\
w / R \\
W / R \\
W / R \\
W / R\end{array}$ & $\begin{array}{l}\mathbf{d} \\
\mathbf{d} \\
\mathbf{R} \\
\mathbf{R}\end{array}$ \\
\hline
\end{tabular}

必 
Location 316-5W PRE

\begin{tabular}{|c|c|c|c|c|c|c|c|c|c|c|c|c|c|}
\hline \multirow[t]{2}{*}{ Paremeter } & \multirow{2}{*}{$\begin{array}{l}\text { Semply } \\
\text { Depth }\end{array}$} & \multicolumn{2}{|c|}{$\begin{array}{r}001020 \\
0.50\end{array}$} & \multicolumn{2}{|c|}{$\begin{array}{r}001021 \\
0.50\end{array}$} & \multicolumn{2}{|l|}{$\begin{array}{r}001022 \\
0.50\end{array}$} & \multicolumn{2}{|l|}{$\begin{array}{r}001023 \\
0.50\end{array}$} & \multicolumn{2}{|l|}{$\begin{array}{r}001019 \\
3.00\end{array}$} & \multicolumn{2}{|l|}{$\begin{array}{r}001018 \\
5.00\end{array}$} \\
\hline & & Recult & $\mathbf{a}$ & Revult & $\mathbf{a}$ & neault & - & Reault & a & Reault & - & Reante & a \\
\hline 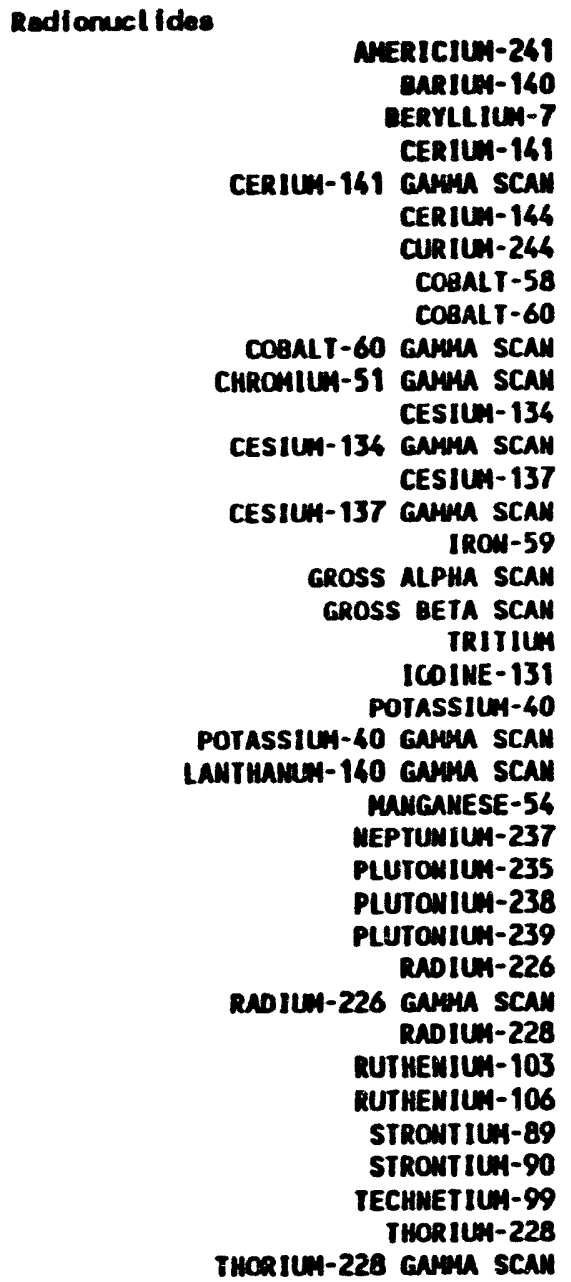 & 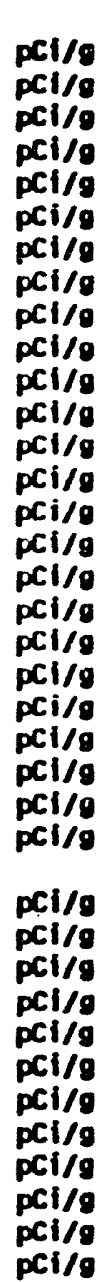 & 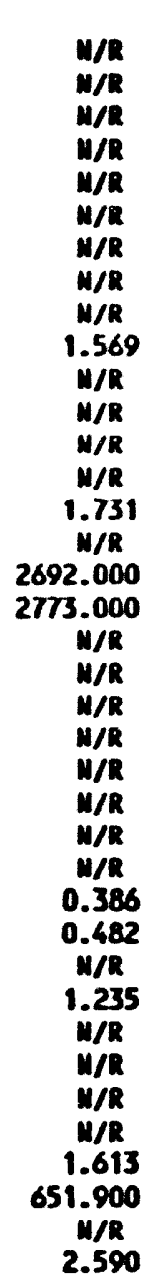 & $\begin{array}{l}\mathbf{d R} \\
\mathbf{d R}\end{array}$ & 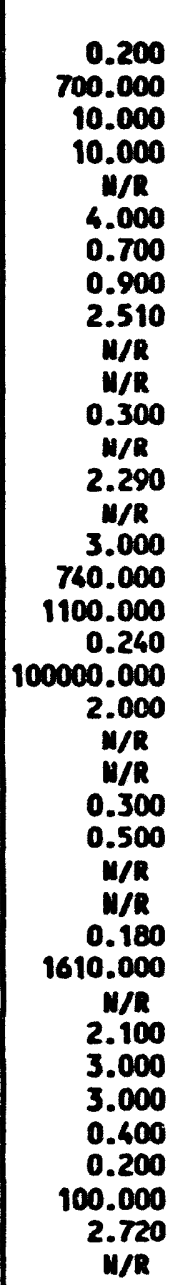 & $\begin{array}{c}U_{R} \\
U_{R} \\
U_{R} \\
U_{R} \\
U_{R} \\
U_{R} \\
U_{R} \\
R \\
U_{R} \\
R \\
U_{R} \\
R \\
R \\
U_{R} \\
U_{R} \\
U_{R} \\
U_{R} \\
U_{R} \\
U_{R}\end{array}$ & 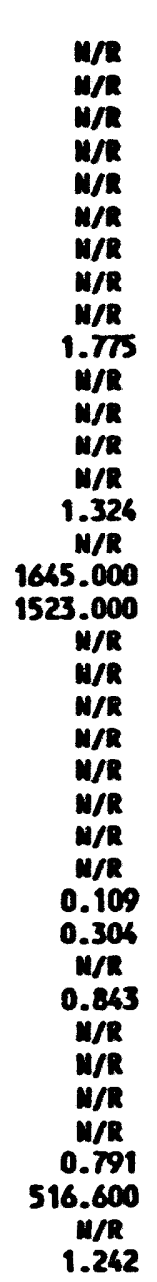 & $\begin{array}{r}\operatorname{UR}_{\mathbf{R}} \\
\mathbf{d R}\end{array}$ & 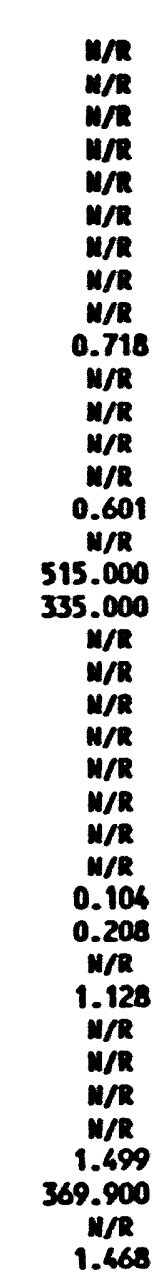 & $\underset{J}{J R}$ & 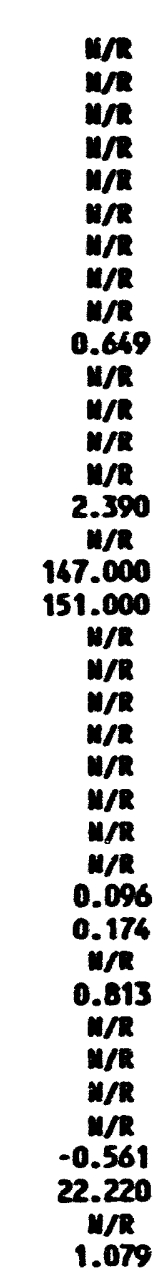 & $\begin{array}{l}\mathbf{d} \\
\mathbf{d} \\
\mathbf{J}\end{array}$ & 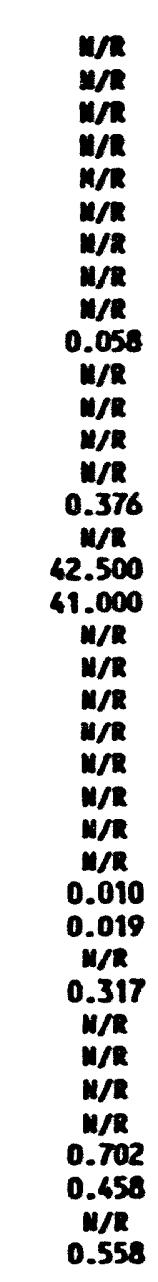 & 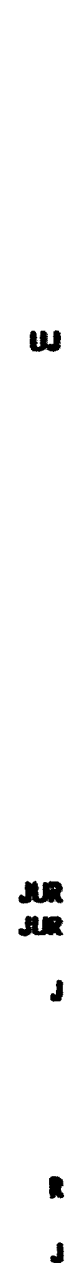 \\
\hline
\end{tabular}


Location 316-5W PRE

\begin{tabular}{|c|c|c|c|c|c|c|c|c|c|c|c|c|c|}
\hline \multirow[t]{2}{*}{ Parcaster } & \multirow{2}{*}{$\begin{array}{l}\text { Sempil } \\
\text { Depth }\end{array}$} & \multicolumn{2}{|c|}{$\begin{array}{r}001020 \\
0.50\end{array}$} & \multicolumn{2}{|c|}{$\begin{array}{r}001021 \\
0.50\end{array}$} & \multicolumn{2}{|c|}{$\begin{array}{r}001022 \\
0.50\end{array}$} & \multicolumn{2}{|c|}{$\begin{array}{r}001023 \\
0.50\end{array}$} & \multicolumn{2}{|c|}{$\begin{array}{r}001019 \\
3.00\end{array}$} & \multicolumn{2}{|c|}{$\begin{array}{r}291018 \\
5.00\end{array}$} \\
\hline & & Result & a & Reault & - & result & - & Reault & a & neaut & a & Readt & e \\
\hline 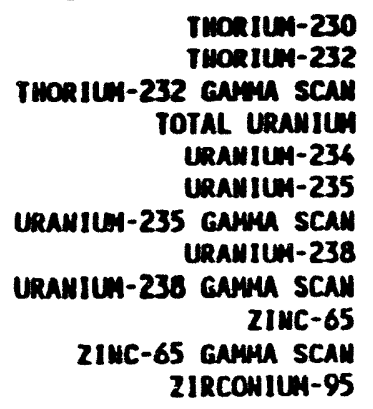 & 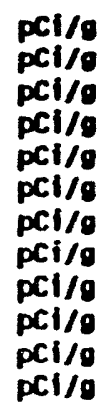 & $\begin{array}{c}W / R \\
W / R \\
0.716 \\
1893.000 \\
2602.000 \\
216.300 \\
M / R \\
1779.000 \\
W / R \\
M / R \\
W / R \\
W / R\end{array}$ & $\begin{array}{l}\mathbf{R} \\
\mathbf{R} \\
\mathbf{R}\end{array}$ & $\begin{array}{c}0.670 \\
0.069 \\
N / R \\
1 / R \\
390.000 \\
19.000 \\
11 / R \\
290.000 \\
N / R \\
0.500 \\
N / R \\
3.000\end{array}$ & $\begin{array}{l}\text { : } \\
2 \\
2 \\
\text { R } \\
\text { un } \\
\text { un }\end{array}$ & $\begin{array}{c}m / 1 \\
m / R \\
0.990 \\
1967.000 \\
1515.000 \\
99.790 \\
w / R \\
1062.000 \\
w / R \\
M / R \\
M / R \\
N / R\end{array}$ & ? & $\begin{array}{c}M / R \\
W / R \\
1.252 \\
499.700 \\
256.800 \\
-11.950 \\
W / R \\
282.700 \\
W / R \\
W / R \\
W / R \\
W / R\end{array}$ & R & $\begin{array}{c}m / R \\
1 / R \\
1.001 \\
206.700 \\
119.600 \\
4.642 \\
11 / 2 \\
93.250 \\
w / R \\
11 / R \\
1 / R \\
1 / R\end{array}$ & ? & $\begin{array}{c}M / 1 \\
m / R \\
0.460 \\
33.300 \\
21.920 \\
2.855 \\
w / R \\
15.360 \\
W / R \\
w / R \\
W / R \\
W / R\end{array}$ & $\mathbf{R}$ \\
\hline
\end{tabular}

岕 
Location 316-5 VPT-1

\begin{tabular}{|c|c|c|c|c|c|c|c|c|c|c|c|c|c|}
\hline \multirow[t]{2}{*}{ Porameter } & \multirow{2}{*}{$\begin{array}{l}\text { Sempl } \\
\text { Depth }\end{array}$} & \multicolumn{2}{|l|}{$\begin{array}{r}801016 \\
0.50\end{array}$} & \multicolumn{2}{|c|}{$\begin{array}{r}001403 \\
1.50\end{array}$} & \multicolumn{2}{|l|}{$\begin{array}{r}001602 \\
4.50\end{array}$} & \multicolumn{2}{|l|}{$\begin{array}{r}001406 \\
6.50\end{array}$} & \multicolumn{2}{|l|}{$\begin{array}{l}\text { co1kes } \\
11.00\end{array}$} & \multicolumn{2}{|l|}{$\begin{array}{c}001408 \\
17.00\end{array}$} \\
\hline & & Result & $\mathbf{a}$ & Result & 0 & result & a & Result & a & Rewlt & - & Rewult & $\mathbf{a}$ \\
\hline 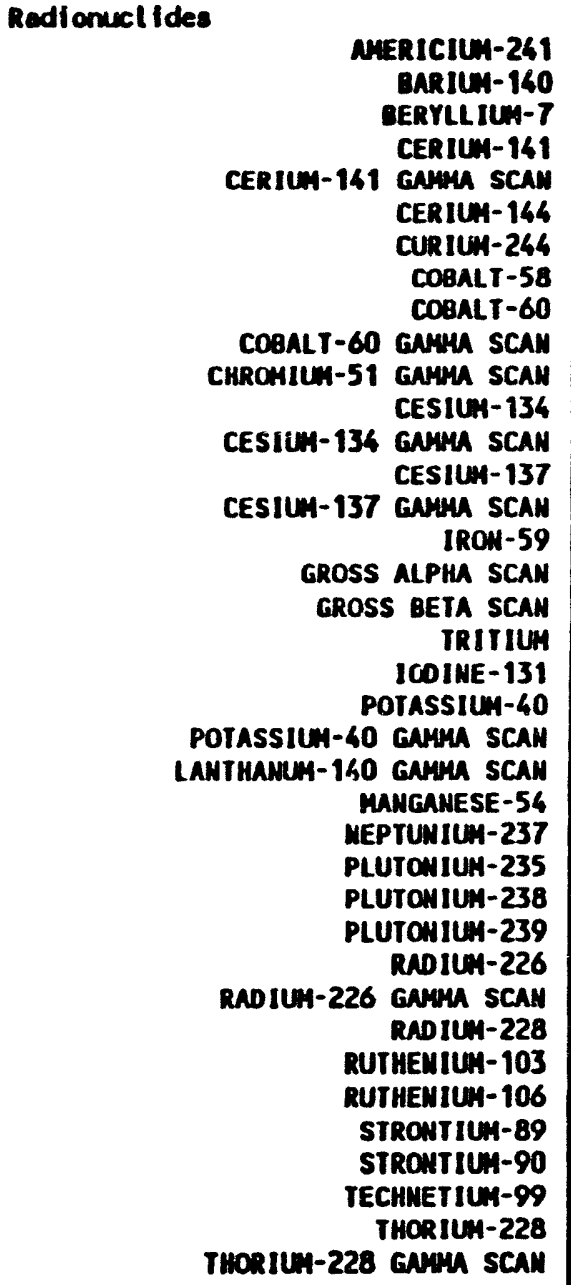 & 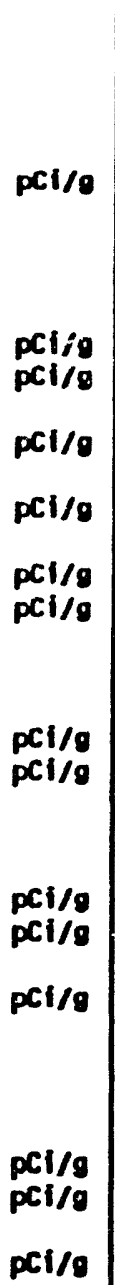 & 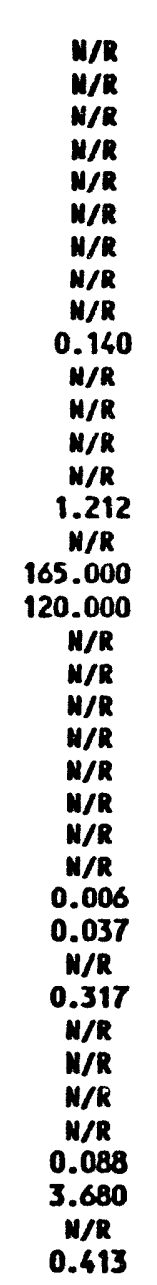 & $\underset{J R}{J R}$ & 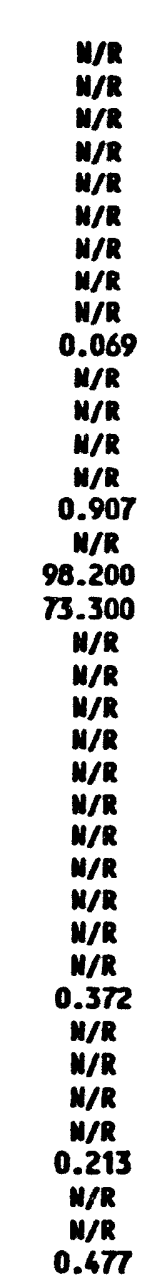 & Us & 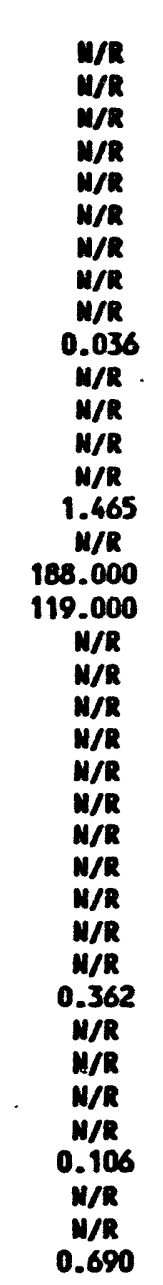 & $\boldsymbol{\omega}$ & 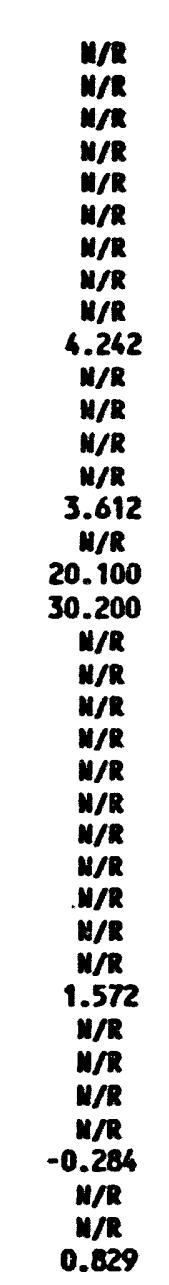 & US & 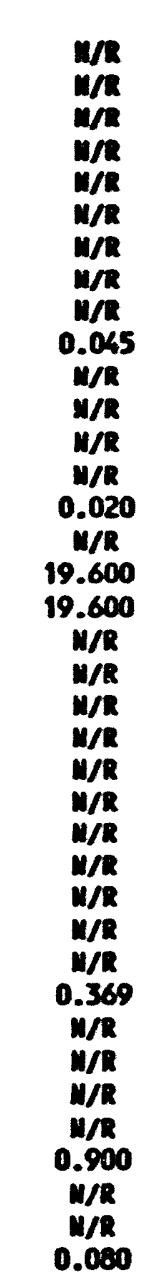 & 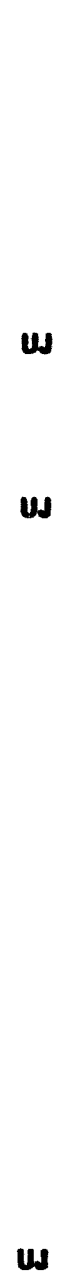 & 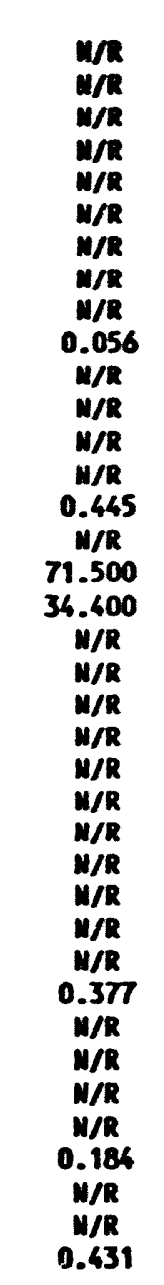 & us \\
\hline
\end{tabular}


Location 316-5 VPT-1

\begin{tabular}{|c|c|c|c|c|c|c|c|c|c|c|c|c|c|}
\hline \multirow[t]{2}{*}{ Parcneter } & \multirow{2}{*}{$\begin{array}{l}\text { Seapi } \\
\text { Depth }\end{array}$} & \multicolumn{2}{|l|}{$\begin{array}{r}001016 \\
0.50\end{array}$} & \multicolumn{2}{|l|}{$\begin{array}{r}001403 \\
1.50\end{array}$} & \multicolumn{2}{|l|}{$\begin{array}{r}001602 \\
4.50\end{array}$} & \multicolumn{2}{|l|}{$\begin{array}{r}101604 \\
6.50\end{array}$} & \multicolumn{2}{|c|}{$\begin{array}{r}001405 \\
11.00\end{array}$} & \multicolumn{2}{|c|}{$\begin{array}{r}001408 \\
17.00\end{array}$} \\
\hline & & Result & 9 & Result & $a$ & Result & 0 & Result & $a$ & Result & a & Result & $\mathbf{a}$ \\
\hline 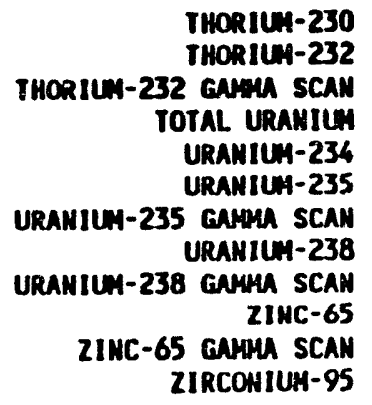 & $\begin{array}{l}\mathrm{pCl} / \mathrm{g} \\
\mathrm{pCl} / \mathrm{g} \\
\mathrm{pCl} / \mathrm{g} \\
\mathrm{pCl} / \mathrm{g} \\
\mathrm{pCl} / \mathrm{g} \\
\mathrm{pCl} / \mathrm{g} \\
\mathrm{pCl} / \mathrm{g} \\
\mathrm{pCl} / \mathrm{g}\end{array}$ & $\begin{array}{c}M / R \\
N / R \\
0.383 \\
80.000 \\
59.690 \\
3.930 \\
N / R \\
44.060 \\
N / R \\
N / R \\
N / R \\
N / R\end{array}$ & $\begin{array}{r}\mathbf{J R} \\
\mathbf{R} \\
\mathbf{R} \\
\mathbf{R}\end{array}$ & $\begin{array}{c}W / R \\
W / R \\
0.699 \\
W / R \\
W 6.890 \\
6.100 \\
W / R \\
32.340 \\
W / R \\
W / R \\
W / R \\
N / R\end{array}$ & $\begin{array}{l}R \\
R \\
R\end{array}$ & $\begin{array}{c}W / R \\
W / R . \\
0.738 \\
W / R \\
59.170 \\
7.730 \\
W / R \\
43.510 \\
W / R \\
W / R \\
W / R \\
N / R\end{array}$ & $\begin{array}{l}\mathbf{R} \\
\mathbf{R} \\
\mathbf{R}\end{array}$ & $\begin{array}{c}W / R \\
N / R \\
1.632 \\
W / R \\
16.860 \\
2.050 \\
N / R \\
12.030 \\
N / R \\
N / R \\
N / R \\
N / R\end{array}$ & $\begin{array}{l}R \\
R \\
R\end{array}$ & $\begin{array}{c}M / R \\
M / R \\
0.447 \\
M / R \\
16.060 \\
2.160 \\
W / R \\
I 1.260 \\
M / R \\
N / R \\
M / R \\
M / R\end{array}$ & $\begin{array}{l}\mathbf{R} \\
\mathbf{R} \\
\mathbf{R}\end{array}$ & $\begin{array}{c}W / R \\
W / R \\
0.601 \\
W / R \\
W / R \\
26.270 \\
3.560 \\
W / R \\
18.620 \\
W / R \\
N / R \\
W / R \\
N / R\end{array}$ & $\begin{array}{l}R \\
R\end{array}$ \\
\hline
\end{tabular}

心 
Location 316-5E POST

\begin{tabular}{|c|c|c|c|c|c|c|c|c|c|}
\hline \multirow[t]{2}{*}{ Paremeter } & \multirow{2}{*}{$\begin{array}{l}\text { Seapy } \\
\text { Depth }\end{array}$} & \multicolumn{2}{|c|}{$\begin{array}{r}801025 \\
0.50\end{array}$} & \multicolumn{2}{|c|}{$\begin{array}{r}801027 \\
0.50\end{array}$} & \multicolumn{2}{|c|}{$\begin{array}{r}801029 \\
0.50\end{array}$} & \multicolumn{2}{|c|}{$\begin{array}{r}801031 \\
0.50\end{array}$} \\
\hline & & Result & $\mathbf{a}$ & Result & a & Recult & $\mathbf{a}$ & Result & $\mathbf{a}$ \\
\hline 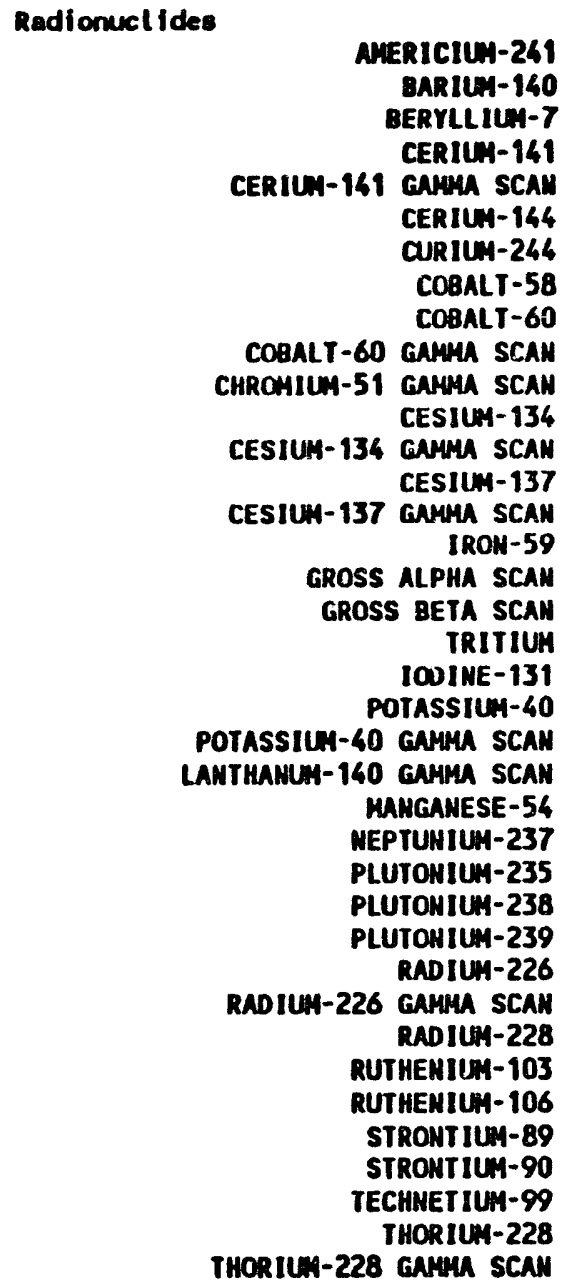 & $\begin{array}{l}\text { pCi/s } \\
\mathrm{pCl} / \mathrm{s} \\
\mathrm{pCl} / \mathrm{g} \\
\mathrm{pCi} / \mathrm{g} \\
\mathrm{pCl} / \mathrm{o} \\
\mathrm{pCl} / \mathrm{o}\end{array}$ & 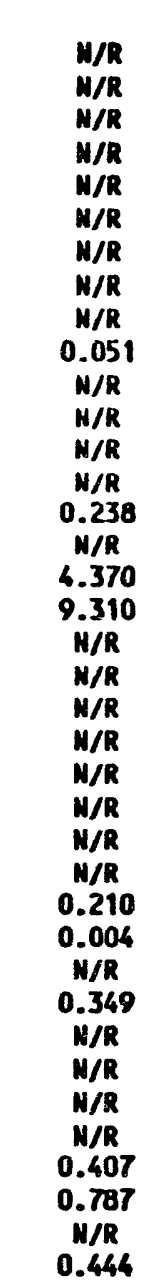 & $\begin{array}{r}\text { JUR } \\
\text { JUR }\end{array}$ & 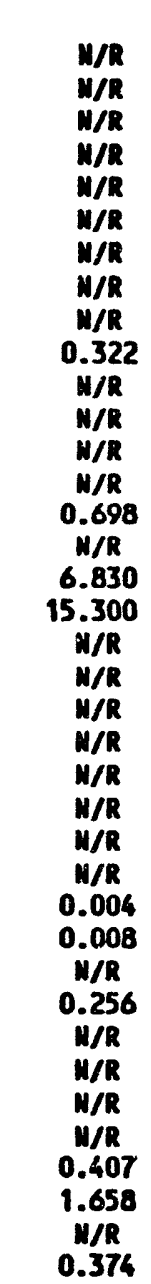 & $\begin{array}{r}\text { JUR } \\
\text { JUR } \\
\text { J }\end{array}$ & 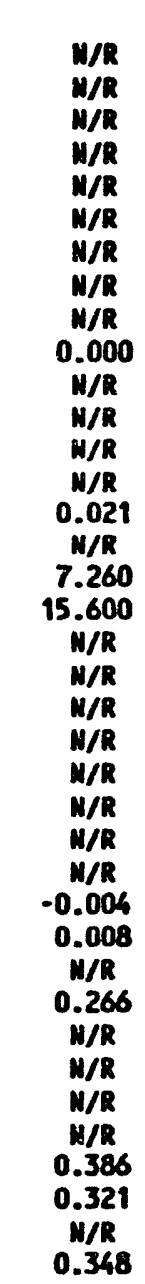 & $\begin{array}{r}\text { JUR } \\
\text { JUR } \\
\text { J }\end{array}$ & 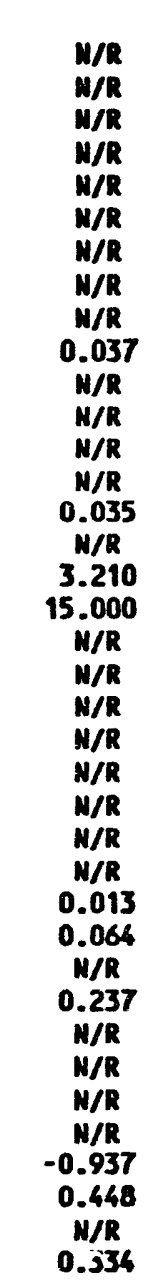 & $\begin{array}{r}\text { JUR } \\
\text { JUR } \\
\text { J }\end{array}$ \\
\hline
\end{tabular}




\section{DISTRIBUTION}

\section{Number of Copies}

Copy No.

\section{OFFSITE}

U.S. Environmental Protection Agency

9,10 Region 10 1200 Sixth Avenue

Seattle, WA 98101

D. L. Duncan

U.S. Environmental Protection Agency

Region 10

712 Swift

Richland, WA 99352

D. R. Einan

Washington State Department of Ecology,

South Sound Center

99 South Sound

Lacey, WA 98503

T. M. Michelena

Washington State Department of Ecology,

99 South Sound Lacey. WA 98503

T. M. Michelena (Ecology, Library)

Washington State Department of Ecology, Nuclear Waste Program

WNP-1, Hanford Site, Building 55

Richland, WA 99352

M. Jaraysi

1 Confederated Tribes and Bands

of the Yakima Indian Nation

P.0. Box 151

Toppenish. Washington 98948

Mr. Russell Jim, Tribal Council

1 Nez Perce Indian Tribe

P.0. Box 365

Lapwai, Idaho 83540-0365

Ms. Donna Powaukee, NPTEC

Confederated Tribes of the Umatilla Indian Reservation

P.0. Box 638

Pendleton, Oregon 97801

Mr. J. R. Wilkenson 
Number of Copies

OFFSITE (continued)

2

U.S. Department of EnergyQuince Orchard Building 19901 Germantown Road Germantown, MD 20874

Mr. M. Janaskie
Copy No.

4,5
ONSITE

8

1

18

3
U.S. Department of EnergyRichland Operations office J. K. Erickson

R. N. Krekel

R. G. McLeod (2) GSSC (MACTEC) (2)

DOE-RL Public Reading Room

Administrative Record

Pacific Northwest Laboratory Hanford Technical Library

Westinghouse Hanford Company

J. A. Eacker (2)

S. N. Luke (7)

S. M. Price

F. A. Ruck III

J. S. Schmid

B. D. Williamson

EPIC

Document Clearance Administration (3)

RCRA Files/GHL

Bechtel Hanford Incorporated

J. R. Freeman-Pollard

J. James

S. D. Johnson
A5-19

A5 -15

A5-19

A4-35

A $1-65$

H6-08

$\mathrm{K} 1-11$

L6-04

$\mathrm{H} 6-23$

H6-23

H6-23

H6-06

B3-15

H6-08

$\mathrm{H} 4-17$

H6-23

H6-03

$\mathrm{H} 4-79$

H4-79
21

22

1,6

2,3

23

24

25

27,28

$7,8,29-33$

44

37

34

35

36

38-40

41

42

43

26 
STATE ENVIRONMENTAL POLICY ACT

ENVIRONMENTAL CHECKLIST

FOR

CLOSURE OF THE 300 AREA PROCESS TRENCHES

REVISION 0

August 1994

WASHINGTON ADMINISTRATIVE CODE

ENVIRONMENTAL CHECKLIST FORMS

(WAC 197-11-960) 
A. BACKGROUND

1. Name of proposed project, if applicable:

Closure of the 300 Area Process Trenches (300 APT).

2. Name of applicants:

U.S. Department of Energy, Richland Operations Office (DOE-RL), and the Westinghouse Hanford Company (Westinghouse Hanford).

3. Address and phone number of applicants and contact persons:

U.S. Department of Energy

Richland Operations office

Post Office Box 550

Richland, Washington 99352

Contact Persons:

S. H. Wisness, Acting Program Manager

Office of Environmental Assurance Permits and Policy (509) 376-6798
Westinghouse Hanford Company P.0. Box 1970

Richland, Washington 99352

\author{
W. T. Dixon, Manager \\ Regulatory Support \\ Waste, Analytical and \\ Environmental Services \\ (509) 376-0428
}

4. Date checklist was prepared:

1994

5. Agency requesting checklist:

Washington State

Department of Ecology

Post Office Box 47600

OTympia, Washington 98504-7600

6. Proposed timing or schedule (including phasing, if applicable):

It is proposed that a plan for closure of the 300 APT be submitted to the Washington State Department of Ecology (Ecology) and the

U.S. Environmental Protection Agency (EPA) by August 15, 1994.

7. Do you have any plans for future additions, expansion, or further activity related to or connected with this proposal? If yes, explain.

The 300 APT are located within the Comprehensive Environmental Response, Compensation, and Liability Act of 1980 (CERCLA) 300-FF-1 Operable Unit (OU). While the 300 APT is designated a treatment, storage, and/or disposal (TSD) unit by the Resource Conservation and Recovery Act of 1976 (RCRA), the closure plan will integrate requirements of both statutes. Closure of the 300 APT will be performed in conjunction with remediation of the 300-FF-1 OU to ensure that the activities of the two units remain physically consistent and to allow the TSD unit closure to capitalize on 
the economies of speed and scale presented by the larger-scale oU activities. This closure plan addresses only the 300 APT and not the adjacent CERCLA areas.

8. List any environmental information you know about that has been prepared, or will be prepared, directly related to this proposal.

The 300 APT has been designated a TSD unit in the Hanford Site Dangerous Waste Part A Permit Application (DOE-RL 1988). The TSD unit will be closed in conjunction with the CERCLA remedial action process for the 300-FF-1 OU. Documents already initiated in support of this activity include a remedial investigation/feasibility study (RI/FS) work plan (DOE-RL 1990), a Phase I RI (DOE-RL 1992d), the Phase I and II FS (DOE-RL 1992e), and the Phase II RI (DOE-RL 1993c). Forthcoming documents include the Phase III FS and Proposed PIan and a Record of Decision (ROD) for the 300-FF-1 OU.

Further, in 1991, the DOE-RL undertook major TSD unit interim-status action in the form of the 316-5 Process Trenches Expedited Response Action (ERA), which was designed to immobilize unit contaminants in order to prevent the possibility of these contaminants entering the groundwater. This ERA was conducted as part of the 300-FF-1 OU RI/FS process. The ERA is documented in the ERA Proposal for the 316-5 Process Trenches (DOE-RL 1991a) and the ERA Assessment for the 316-5 Process Trenches (DOE-RL 1992a).

9. Do you know whether applications are pending for government approvals of other proposals directly affecting the property covered by your proposal? If yes, explain.

The Draft Hanford Facility Part A Permit (Ecology 1994b) was prepared and issued for public comment by Ecology and the EPA Region 10 in February 1994. This permit is designed to identify the Hanford Site as one RCRA TSD facility.

A CERCLA FS is being prepared that will provide the basis for an ROD for the remediation of the entire 300-FF-1 OU. The anticipated date for the ROD is the second quarter of calendar year 1995.

10. List any government approvals or permits that will be needed for your proposal, if known.

The approval of this SEPA Checklist and approval of the closure plan for the 300-FF-1 OU by Ecology is required. Final closure of this TSD will entail withdrawal of the unit-specific Part A, Form 3.

11. Give brief, complete description of your proposal, including the proposed uses and the size of the project and site. There are several questions later in this checklist that ask you to describe certain aspects of your proposal. You do not need to repeat those answers on this page.

The closure plan will contain information describing the closure of the 300 APT to levels determined by requirements of both CERCLA and RCRA as implemented by Ecology's Dangerous Waste Regulations (WAC 173-303-610). It is believed that because the 300 Area of the Hanford Site will 
continue to operate in a fashion that will preclude unrestricted use, the site will be cleaned up to industrial-based standards.

The site consists of two parallel, unlined trenches running north and south separated by an earthen berm. A wire mesh fence surrounds the unit and a metal birdscreen covers the length of the trenches to prevent intrusion by wildlife. A concrete outfall weir box at the south end of the trenches provides the effluent feed source. These trenches are roughly 350 meters (1,200 feet) long and approximately 3.5 meters (11 feet) deep. The original width of the trenches was 9 meters (30 feet), but they were widened after the ERA was conducted in 1991. This ERA also consolidated low-level mixed waste soils in the northern 91 meters ( $300 \mathrm{feet}$ ). The trenches are approximately 5 meters (18 feet) above the water table.

It is anticipated that remediation and/or removal of 300 APT TSD unit soils, structures, and/or equipment will be required for unit closure. Physical closure activities for TSD unit soil, structures, and equipment will be carried out by the 300-FF-1 OU in accordance with 300-FF-1 ROD specifications and 300 APT closure plan specifications, which will be in substantive agreement. The ROD will select a remedy from alternatives and information presented during the RI/FS. The potential alternatives considered to date are containment (Hanford Site Barrier), removal and disposal, or removal and treatment (soilwashing).

Soilwashing is currently considered the most promising alternative and vendor testing has been and is being conducted on soilwashing equipment in order to determine its effectiveness on Hanford Site soils. Soilwashing will greatly reduce the volume of waste by separating the contamination, located mostly on the finest particles of the soil (i.e., the 'fines'), from the remaining coarser fraction of the soil matrix. The fines will then be appropriately designated as waste. The courser fraction, which will represent the majority of the soil volume, could be used for backfill during site restoration.

Other TSD unit media will be removed and decontaminated as feasible and necessary. These media will likely include any piping that is located within the TSD boundaries, and the concrete outfall structure and weir box. The remediation of soil contaminated from pipeline leaks within the TSD unit boundaries will be documented by this closure plan. Those areas outside the boundaries will be addressed as part of the OU closure.

In addition, if a removal and treatment alternative is selected, the closure plan will include sampling of the excavated and decontaminated soil to determine the soil's suitability as backfill for 300 APT

excavation(s). The site will be contoured and revegetated or otherwise restored to the 300-FF-1 OU ROD specifications.

12. Location of the proposal. Give sufficient information for a person to understand the precise location of your proposed project, including a street address, if any, and section, township, and range, if known. If a proposal would occur over a range of area, provide the range or boundaries of the site(s). Provide a legal description, site plan, vicinity map, and topographic map, if reasonably available. While you should submit any plans required by the agency, you are not required to 
duplicate maps or detailed plans submitted with any permit applications related to this checklist.

The 300 APT are situated north of the 300 Area, which is located at the southern portion of the Hanford Site. The Hanford Site is located in southcentral Washington State, near the confluence of the Columbia, Yakima, and Snake Rivers. The Columbia River, the nearest natural water body to the 300 APT, is located 305 meters (1,000 feet) to the east.

The 300-FF-1 OU, which is partially located within the 300 Area, is found in Section 2, Township 10 north, Range 28 east.

\section{B. ENVIRONMENTAL ELEMENTS}

1. Earth

a. General description of the site (circle one): Flat, rolling, hilly, steep slopes, mountainous, other

Flat.

b. What is the steepest slope on the site (approximate percent slope)?

The trench walls have an approximate 40-percent slope. The slope of the land at the site is less than 2 percent.

c. What general types of soils are found on the site (for example, clay, sandy gravel, peat, muck)? If you know the classification of agricultural soils, specify them and note any prime farmland.

The soil at the 300 APT consists of mostly of sand with interspersed large cobbles.

No farming occurs at the Hanford Site.

d. Are there surface indications or history of unstable soils in the immediate vicinity? If so, describe.

No.

e. Describe the purpose, type, and approximate quantities of any filling or grading proposed. Indicate source of fill.

The extent of fill material necessary will be dependent upon the selected remedy as presented in the ROD for the 300-FF-1 ou. If containment (Hanford Barrier) is selected, extensive backfilling is unlikely; however, grading in order to reestablish a normal terrain for the vicinity prior to installing the barrier could be necessary. If the removal 
and disposal remedy is selected, the current trenches and the newly excavated areas would require more extensive backfilling using offsite material and/or grading in order to reestablish a normal terrain for the vicinity. If removal and treatment (soilwashing) is selected, less offsite fill would be necessary because of the use of the onsite remediated fraction as backfill.

To backfill the currently configured trenches to the level of grade surrounding them would require approximately

26,760 cubic meters $(35,000$ cubic yards) of material. This material would come from other, noncontaminated areas of the Hanford Site.

f. Could erosion occur as a result of clearing, construction, or use? If so, generally describe.

Because of the soil types and dry climate, erosion is not expected. In addition, the area would be resurfaced, either at the end of this closure activity or when the entire $\mathrm{OU}$ is remediated, to provide continuity with adjacent areas and to ensure proper drainage characteristics.

g. About what percent of the site will be covered with impervious surfaces after project construction (for example, asphalt or buildings).

The final site configuration for the 300 APT is as yet undetermined. Final site configuration will be consistent with the method of remediation and future usage of the property as specified in the ROD for the 300-FF-1 OU. WAC 173-303-610 performance standards must be considered in restoration of the site to the appearance and use of the surrounding land areas where appropriate. If an immediate use of the property requiring the construction of impervious surfaces is not indicated, the area will likely be contoured to match existing topography and revegetated.

h. Proposed measures to reduce or control erosion, or other impacts to the earth, if any:

The revegetation effort and appropriate surface contouring will provide a measure of erosion control deemed adequate given the Hanford Site's dry climate and mild slope.

2. Air

a. What types of emissions to the air would result from the proposal (i.e., dust, automobile, odors, industrial wood smoke) during construction and when the project is completed? If any, generally describe and give approximate quantities, if known. 
If the remedy selection process for the ou settles upon the removal alternative, the activity would have the potential to generate dust. This dust would possibly contain some contaminants. The impacts of dust to the environment and/or to site workers would be mitigated by proper dust abatement measures. Such measures could entail activities such as site watering and/or stopping work during high winds. They could al so entail site worker protection measures such as protective clothing and respirators that would be specified in the appropriate documents governing job safety (e.g., Hazardous Waste Operations Permit (HWOP).

In addition, vehicles and machinery used in the closure activities would produce minor amounts of air emissions in the form of exhaust gases. These emissions can be considered negligible when compared to total Hanford Site releases. At the end of closure activities, the 300 APT unit will be deactivated and the site will be stabilized and no longer produce emissions.

b. Are there any off-site sources of emissions or odors that may affect your proposal? If so, generally describe.

No.

c. Proposed measures to reduce or control emissions or other impacts to the air, if any?

In order to control the amount of dust generated by excavation activities, water trucks could be used to periodically spray designated areas, work may be halted as necessitated by winds, and/or additional measures such as those described in [40].

\section{Water}

a. Surface

1. Is there any surface water body on or in the immediate vicinity of the site (including-year-round and seasonal streams, saltwater, lakes, ponds, wetlands)? If yes, describe type and provide names. If appropriate, state what stream or river it flows into.

The Columbia River is approximately 305 meters ( 1,000 feet) east of the trenches. There are no other natural bodies of water near the site. There are some manmade water treatment basins also located in the 300-FF-1 0U. These basins are used for treatment of process effluent and sanitary waste discharge and would not be impacted by the proposed activity. 
2. Will the project require any work over, in, or adjacent to (within 200 feet) the described waters? If yes, please describe and attach available plans.

No.

3. Estimate the amount of fill and dredge material that would be placed in or removed from surface water or wetlands and indicate the area of the site that would be affected. Indicate the source of fill material.

None.

4. Will the proposal require surface water withdrawals or diversions? Give general description, purpose, and approximate quantities if known.

No

5. Does the proposal lie within a 100-year floodplain? If so, note location on the site plan.

The project location is not within the 100-year floodplain.

6. Does the proposal involve any discharges of waste materials to surface waters? If so, describe the type of waste and anticipated volume of discharge.

No discharge of waste materials to surface waters would occur.

b. Ground

1. Will ground water be withdrawn, or will water be discharged to ground water? Give general description, purpose, and approximate quantities if known.

Water would not be withdrawn from or discharged to the ground. 
2. Describe waste material that will be discharged into the ground from septic tanks or other sources, if any (for example: Domestic sewage; industrial, containing the following chemicals; agricultural..., etc.,). Describe the general size of the system, the number of such systems, the number of houses to be served (if applicable), or the number of animals or humans the system(s) are expected to serve.

No waste material would be discharged into septic tanks or the ground.

\section{c. Water Run-off (including storm water)}

1. Describe the source of run-off (including storm water) and method of collection and disposal, if any (include quantities, if known). Where will this water flow? Will this water flow into other waters? If so, describe.

The Hanford Site has a mild desert climate and receives only 6 to 7 inches of annual precipitation. This small amount of natural precipitation poses little threat of erosion to the unit and is readily absorbed into the soil on and near the site. If a removal remedy is selected, erosion of site soils occurring during remediation will be corrected as a portion of site restoration. In the event that the containment remedy (e.g., Hanford Barrier) is selected, the barrier would be designed to discourage erosion.

2. Could waste materials enter ground or surface waters? If so, generally describe.

Treatment, storage, and/or disposal closure waste is not anticipated to enter ground or surface waters regardless of the remedy selected for site remediation.

Contaminated soils will either be removed or immobilized if covered with a barrier. Any contaminated waste generated during a soil treatment phase of remediation would be managed as waste that would require containerized storage for shipment and disposal.

d. Proposed measures to reduce or control surface, ground, and run-off water impacts, if any:

No impacts to water are expected by this proposal. 


\section{Plants}

a. Check or circle the types of vegetation found on the site.

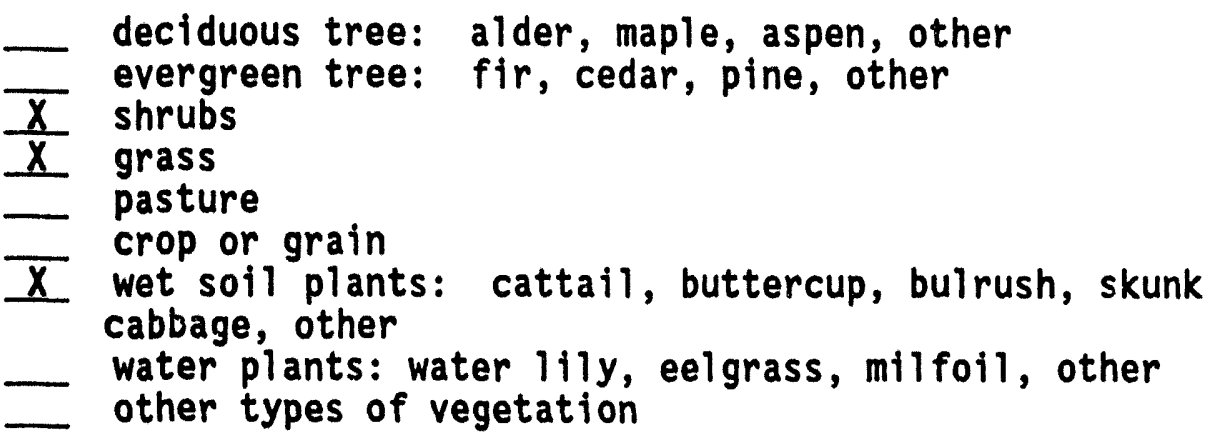

The 300 APT and the area immediately adjacent contain both dryland shrubs and grasses typically found at the Hanford Site as well as some cattails and reeds, characteristic of wet soils.

b. What kind and amount of vegetation will be removed or altered?

These wet soil plants, however, may be contaminated to some degree and will be removed and disposed of appropriately.

Some sagebrush and grasses, both annual and perennial, and the wet soil plants will be disturbed by work in the 300 APT. This vegetation removal might be mitigated by revegetation efforts when the site is closed.

c. List threatened or endangered species known to be on or near the site.

No threatened or endangered plant species are known to occur on or near the project sites.

d. Proposed landscaping, use of native plants, or other measures to preserve or enhance vegetation on the site, if any:

Restoration will be commensurate with the remedial alternative and future site usage specified by the ROD for the 300-FF-1 0U. Containment as a remedial alternative would provide for long-tarm ground cover. Vegetation would be considered in its design. Performance of a removal alternative would also require site restoration that could include backfilling, grading, and the use of appropriate, native vegetation. 


\section{Animals}

a. Circle any birds and animals which have been observed on or near the site or are known to be on or near the site:

Birds: hawk, heron, eagle, songbirds.

Mammals: deer, bear, elk, beaver.

Fish: bass, salmon, trout, herring, shellfish.

Because of the proximity of the Columbia River, there are a wide variety of bird species found in the immediate vicinity of the proposed action. Because of the presence of metal grates, which extend the length of the trenches, these bird species cannot gain access to the contaminated effluent. The area is home to a variety of small mammals found throughout the Hanford Site and occasional deer. There are no fish in the trenches.

b. List any threatened or endangered species known to be on or near the site.

of the two federal- and state-listed endangered species observed on the Hanford Site, the bald eagle is a regular winter visitor, appearing principally along the Columbia River, and the peregrine falcon is an uncommon visitor. The state-listed American white pelican is an uncommon seasonal resident along the Columbia River. No federal-or statelisted endangered species are known to occur on or near the 300 Area. The bald eagle and the American white pelican, while found along the Columbia River, do not usually frequent the 300-FF-1 0U.

c. Is the site part of a migration route? If so, explain.

The nearby rivers, both the Columbia and Yakima, are part of the broad Pacific Flyway; however, screens keep birds or waterfowl out of the trenches.

d. Proposed measures to preserve or enhance wildlife, if any:

If the trenches are backfilled and/or revegetated as a portion of the selected remedy for the 300-FF-1 OU, such vegetation could become habitat for some species found at the Hanford Site. However, the current use of the property is industrial and is anticipated to remain so for the foreseeable future; consequently, wild? ife inhabitation of the property will iikely not be encouraged. 
6. Energy and Natural Resources

a. What kinds of energy (electric, natural gas, oil, wood stove, solar) will be used to meet the completed project's energy needs? Describe whether it will be used for heating, manufacturing, etc.

Gasoline and electricity will be temporarily required during TSD unit remedial action. After closure, the TSD unit site will have no foreseeable energy needs.

b. Would your project affect the potential use of solar energy by adjacent properties? If so, generally describe.

No.

c. What kinds of energy conservation features are included in the plans of this proposal? List other proposed measures to reduce or control energy impacts, if any:

None.

7. Environmental Health

a. Are there any environmental health hazards, including exposure to toxic chemicals, risk of fire and explosion, spill, or hazardous waste, that could occur as a result of this proposal? If so, describe.

Workers could be exposed to dangerous and/or radioactive waste constituents during site remediation. The nature and extent of worker exposure will depend upon the remedy selected for TSD unit remediation by the ROD for the OU.

1. Describe special emergency services that might be required.

Hanford Site security, fire response, and ambulance services are on call at all times in the event of an onsite emergency.

2. Proposed measures to reduce or control environmental health hazards, if any:

Proper operating procedures (e.g., dust abatement) will minimize the risk of a harmful release of radioactive materials during site remediation activities and proper worker safety measures (e.g., protective clothing) wil1 minimize worker exposures to as low as reasonably achievable levels. After trench remediation (by containment or remcval) the trenches will pose no threat to human health or the environment. 
b. Noise

1. What type of noise exists in the area which may affect your project (for example: traffic, equipment, operation, other)?

None.

2. What types and levels of noise would be created by or associated with the project on a short-term or a long-term basis (for example: traffic, construction, operation, other)? Indicate what hours noise would come from the site.

Excavation equipment and machinery would produce a temporary increase in noise levels in the immediate vicinity of the $300-F F-1$ oU. These increases would occur primarily during the day and cease when the closure activities are completed.

3. Proposed measures to reduce or control noise impacts, if any:

The site of the 300 APT is currently an industrial area and a temporary increase in noise during site remediation will have no impact requiring noise abatement.

8. Land and Shoreline Use

a. What is the current use of the site and adjacent properties?

The 300 Area is a highly developed portion of the Hanford Site that has been used primarily for laboratory support and research for the operations conducted by the DOE and its predecessor, the Atomic Energy Commission. In addition, research programs in support of other agencies have been conducted in this area. The 300-FF-1 oU has several

individual waste units within its boundaries. These include several solid waste burial grounds, process water treatment ponds, ash pits, and sanitary water trenches.

b. Has the site been used for agriculture? If so, describe. No part of the Hanford Site has been used for agricultural purposes since 1943.

c. Describe any structures on the site.

While the 300 Area contains many structures, the 300-FF-1 OU, and specifically the 300 APT, is free of buildings, however a concrete weir box exists at the southern end of the trenches. 
d. Will any structures be demolished? If so, what?

No structures except the weir box will be demolished.

e. What is the current zoning classification of the site?

The Hanford Site is zoned by Benton County as an Unclassified Use district.

f. What is the current comprehensive plan designation of the site?

The 1985 Benton County Comprehensive Land Use Plan designates the Hanford Site as the "Hanford Reservation." Under this designation, 7 and on the Hanford Site may be used for "activities nuclear in nature." Nonnuclear activities are authorized "if and when DOE approval for such activities is obtained."

g. If applicable, what is the current shoreline master program designation of the site?

Does not apply.

h. Has any part of the site been classified as an

"environmentally sensitive" area? If so, specify.

No.

i. Approximately how many people would reside or work in the completed project?

None.

j. Approximately how many people would the completed project displace?

None.

k. Proposed measures to avoid or reduce displacement impacts, if any:

Does not apply.

1. Proposed measures to ensure the proposal is compatible with existing and projected land uses and plans, if any:

Future land use for this area has not yet been determined. The CERCLA remedial action process for the 300-FF-1 OU will consider all reasonable future land use scenarios in its establishment of appropriate cleanup levels and its selection of a remedial method to achieve those levels. 
9. Housing

a. Approximately how many units would be provided, if any? Indicate whether high, middle, or low-income housing.

None.

b. Approximately how many units, if any, would be eliminated? Indicate whether high, middle, or low-income housing.

None.

c. Proposed measures to reduce or control housing impacts, if any:

Does not apply.

10. Aesthetics

a. What is the tallest height of any proposed structure(s), not including antennas; what is the principal exterior building material(s) proposed?

No onsite building is currently proposed.

b. What views in the immediate vicinity would be altered or obstructed?

None.

c. Proposed measures to reduce or control aesthetic impacts, if any:

The backfilled trenches would be revegetated, which will increase the aesthetic value of the area.

11. Light and Glare

a. What type of light or glare will the proposal produce? What time of day would it mainly occur?

None.

b. Could light or glare from the finished project be a safety hazard or interfere with views?

No.

c. What existing off-site sources of light or glare may affect your proposal?

None. 
d. Proposed measures to reduce or control light and glare impacts, if any:

Does not apply.

\section{Recreation}

a. What designated and informal recreational opportunities are in the immediate vicinity?

The 300 Area is within the Hanford Site boundary and public access is restricted.

b. Would the proposed project displace any existing recreational uses? If so, describe.

No.

c. Proposed measures to reduce or control impacts on recreation, including recreation opportunities to be provided by the project or applicant, if any?

Does not apply.

13. Historic and Cultural Preservation

a. Are there any places or objects listed on, or proposed for, national, state, or local preservation registers known to be on or next to the site? If so, generally describe.

There are no places or objects that have special historic or cultural significance. Because the trenches occupy a disturbed location, no cultural resources are expected to be disturbed by excavations.

b. Generally describe any landmarks or evidence of historic, archaeological, scientific, or cultural importance known to be on or next to the site.

There are no known archaeological, historical, or native American religious sites on or next to the proposed location. Excavation will be halted in the event that the project uncovers any artifacts or archaeological finds.

c. Proposed measures to reduce or control impacts, if any:

A cultural resources review is triggered by an excavation permit, and would ensure the consideration of potentially significant cultural sites. 
14. Transportation

a. Identify public streets and highways serving the site, and describe proposed access to the existing street system. Show on site plans, if any.

Access to the trenches is served by Stevens Drive, the main north-south route leading to the 300 Area. Existing gravel roads connect Stevens Drive to the 300 APT.

b. Is site currently served by public transit? If not, what is the approximate distance to the nearest transit stop?

Public transportation is provided several miles to the south in the City of Richland. There is no public transit system for the 300 Area, although a bus system serves the area for employees.

c. How many parking spaces would the completed project have? How many would the project eliminate?

Does not apply.

d. Will the proposal require any new roads or streets, or improvements to existing roads or streets, not including driveways? If so, generally describe (indicate whether public or private).

Several temporary roads might be required to introduce earthmoving equipment to the trenches and to site the soil washing equipment.

e. Will the project use (or occur in the immediate vicinity of) water, rail, or air transportation? If so, generally describe.

The 300-FF-1 ou is located immediately to the east of the railroad corridor that serves the 300 Area. No additional work to this corridor or new railroad spurs will te required as part of this project.

f. How many vehicular trips per day would be generated by the completed project? If known, indicate when peak volumes would occur.

Daily vehicular trips would be negligible.

g. Proposed measures to reduce or control transportation impacts, if any:

None. 


\section{Public Services}

a. Would the project result in an increased need for public services (for example: fire protection, police protection, health care, schools, other)? If so, generally describe.

No.

b. Proposed measures to reduce or control direct impacts on public services, if any:

Does not apply.

16. Utilities

a. List utilities currently available at the site: electricity, natural gas, water, refuse service, telephone, sanitary sewer, septic system, other:

Electricity, potable water, telephone, sewage septic system, and refuse services are currently available in the 300 Area and will be available at the site on a temporary basis as necessary during unit remediation.

b. Describe the utilities that are proposed for the project, the utility providing the service, and the general construction activities on the site or in the immediate vicinity which might be needed.

No additional utilities will be introduced, however, minor modifications to the electrical system may be required. 


\section{SIGNATURES}

The above answers are true and complete to the best of my knowledge. We understand that the lead agency is relying on them to make its decision.

Gous E Taemusen

James E. Rasmussen, Acting Program Manager

Office of Environmental Assurance,

Permits, and Policy

U.S. Department of Energy

Richland Operations office

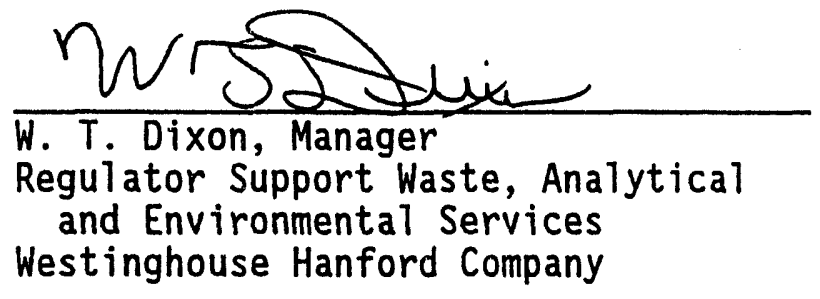

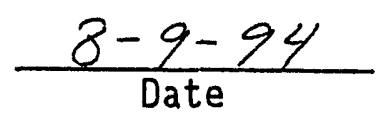

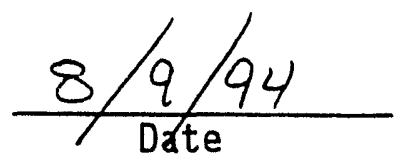



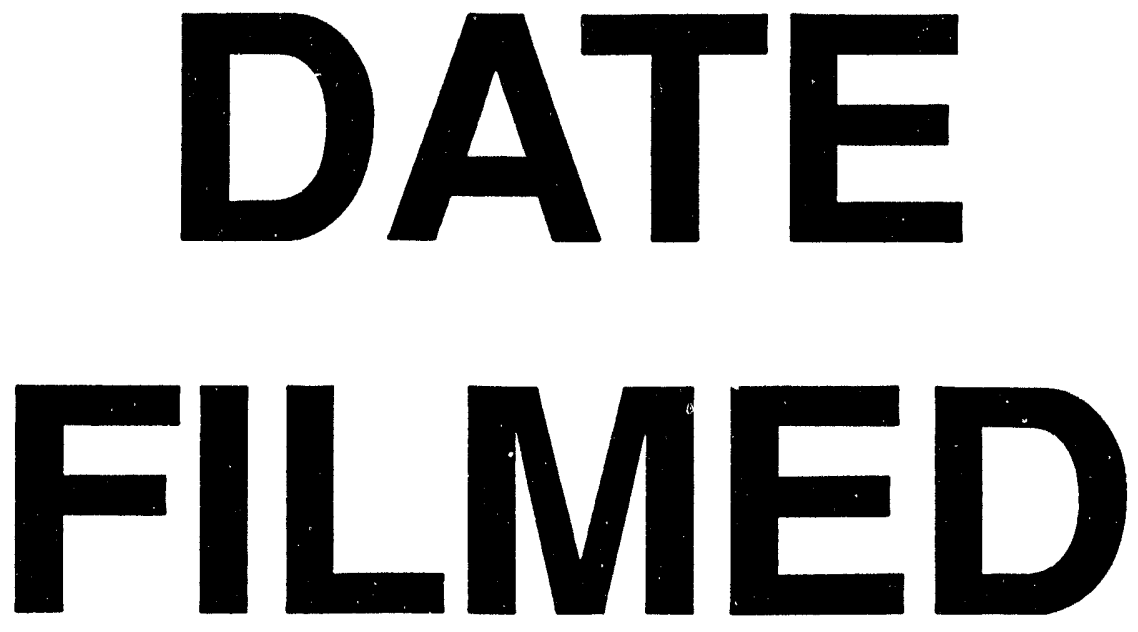

$10 / 18 / 94$
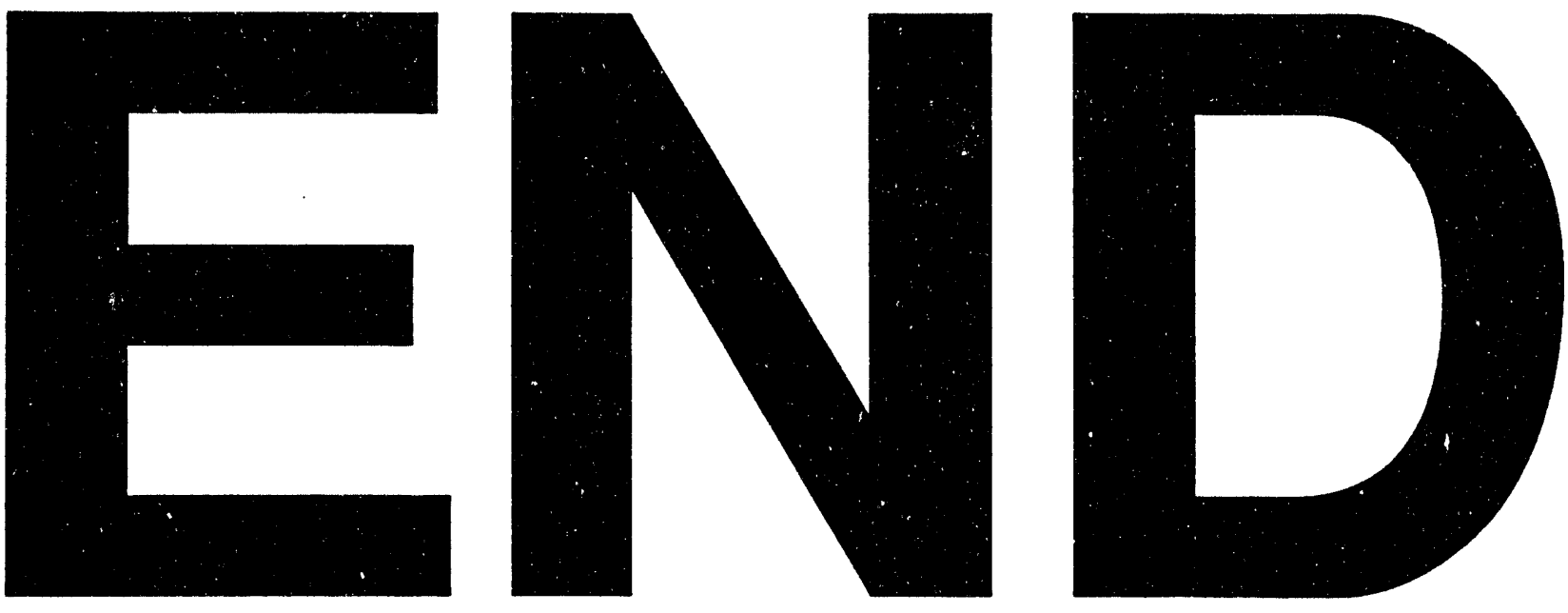
